\title{
Un. 1156
}

\section{Creep Deformation and Rupture Behavior of Type 304/308 Stainless Steel Structural Weldments}

\author{
W. J. McAfee \\ M. Ricr.ardson \\ W. K. Sartory
}




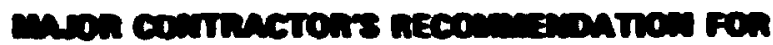

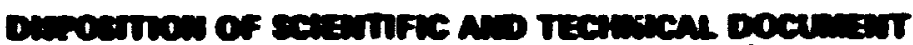

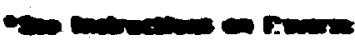

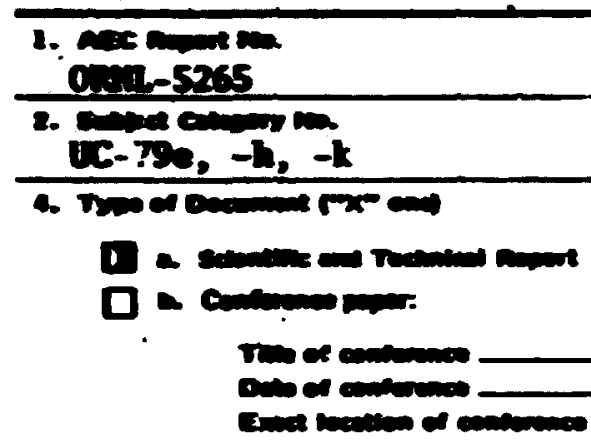

3. The Crep Daforntice and Dpture Dahnvior of Type $304 / 303$ Stuinless Steel Structural Welduats. Authors: W.J. MeAfee, M. Richnedson G.K. Sartory

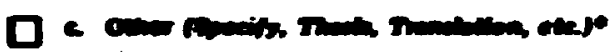

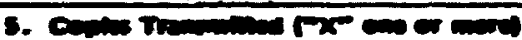

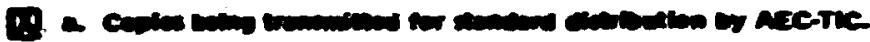

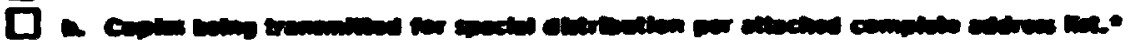

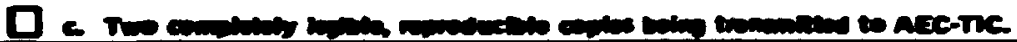

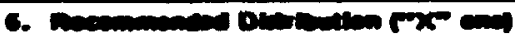

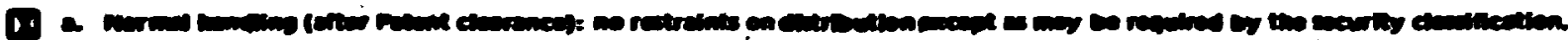

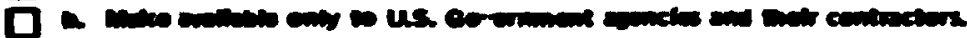

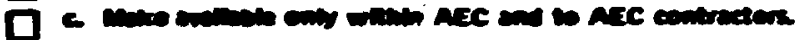

D a rase

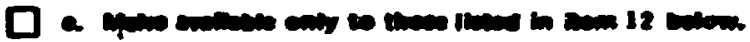

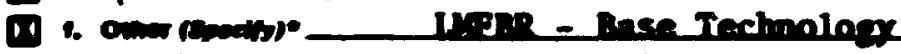

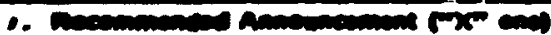

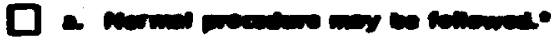

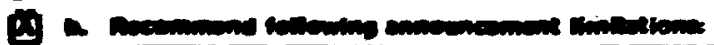

Irigin - Dase Techolory

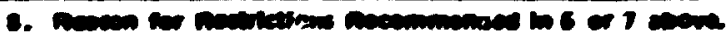

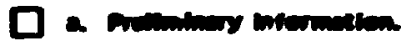

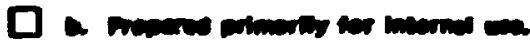

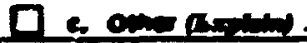

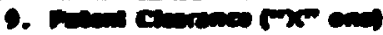

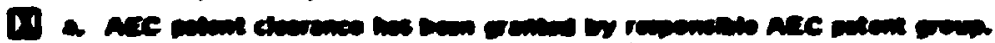

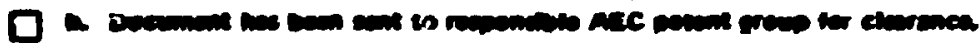

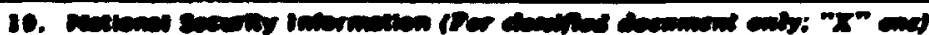

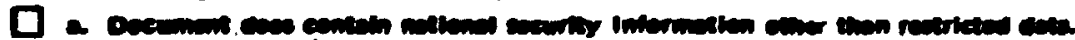

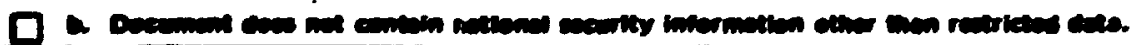

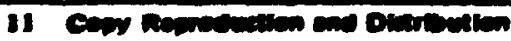

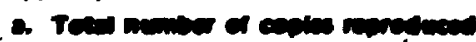

381

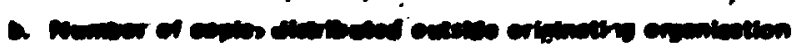

288

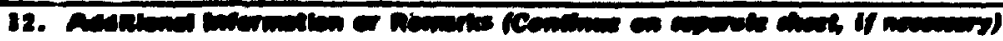

UPER - Dase Technology

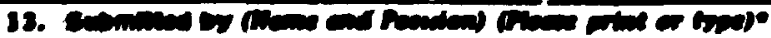

P. S. Mter. cinstiftcation officer 


\section{ORAI -5265}

Dist. Categor; UC-79,

$-79 e,-79 h,-792$

Contrect Do. H-7405-eng-26

Bngineering Technology Division

CRESTP DEFOEATIOW NWD KUPTURE BEHAVIOR OP TYPE 301./308

STAIIISSS STERL STRUCY'RAL WELDMEATS

U. J. McAfee M. Richardson

H. K. Sartory

Manuscript Completed - 5-12-77

Date Published - June 1977

Prepared by the

OAK RIDGI MATIOAAL IABORATORY

Oak Ridge, Tennessee 37830

operated by

UNIOA CARBITE CORPORATION

for the

ETIERGY RLESRARCH AID DEVELOFAGAT ADNINISTRATIOI 
Answincr $\ldots \ldots \ldots \ldots \ldots \ldots \ldots \ldots \ldots \ldots \ldots \ldots \ldots \ldots \ldots \ldots \ldots \ldots \ldots \ldots \ldots \ldots$

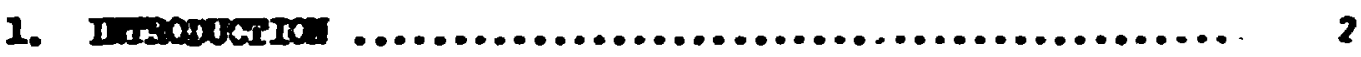

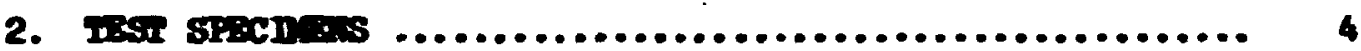

2.1 Test specimen Desion and Furication ................ 4

2.1.1 WCR-1 specinen .......................... \&

2.1.2 wer-2 opecinan ......................... 12

2.2 Description of Teat Welde ........................ 13

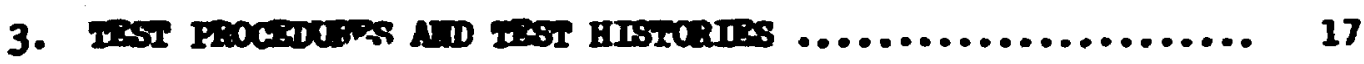

3.1 Description of Teat Facility ................... 17

3.2 Test Procedure and Historles ...................... 21

3.2.1 Specinen 1-2. ............................ 25

3.2.2 Specinen 2-10 ........................... 25

3.2.3 Specinen 3-1n ............................. 30

3.2 .4 Specimen 1-12 .............................. 30

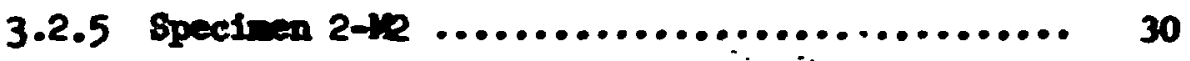

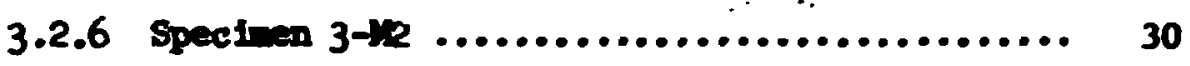

3.2.7 Specinen $4+12 \ldots \ldots \ldots \ldots \ldots \ldots \ldots \ldots \ldots \ldots . . \ldots \ldots$

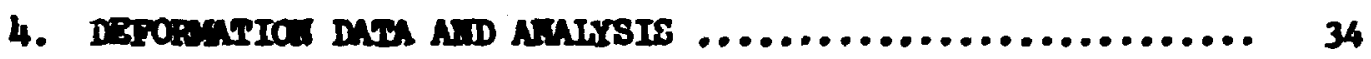

4.1 Deformation Data ................................. 34

4.2 Amblysis of Deformetion Data ...................... 35

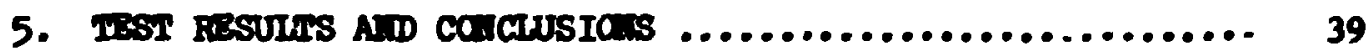

5.1 Deformetion Behavion of specimens .................. 39

5.2 Pallure Bebavior of specinens .................... 44

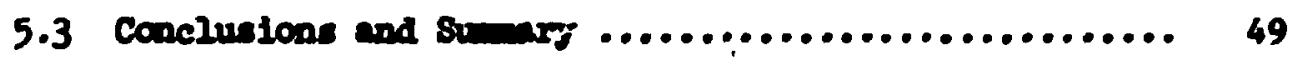

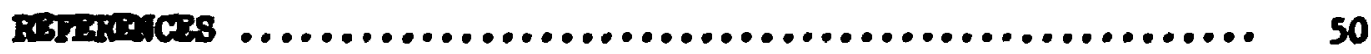

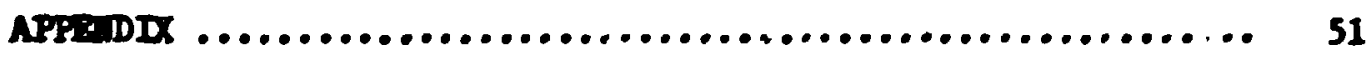


Cicesp Itro:

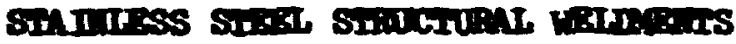

W. J. Hentee U. Richnrison

U. K. Sartary

\section{ABsumacx}

The creep deforeation and rupture of typ 304/308 stain-

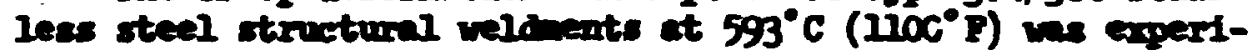

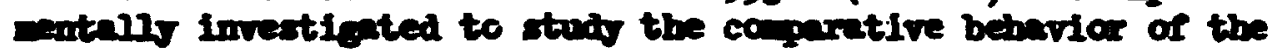
base netel and weld netel contituents. The tests wers conincted in support of aik' progen to develop high-toperature structural deston nethods applicable to liqual-netal ont breeder reactor (ILBB) ates co posents that cperate in the cresp range. The opecinens uned were thin-walled, ridet circular cylinders cepped with either flat ar heriopherienl beads and tested under internal as pressure. Cires ferential welds were located in diffurent regions of the cylinder or head and, Ith ape exception, were bocetrically duplicated by all base netal regions in co panion opecinens. Berults sre yresented on the co parative deformation and rupture beharior of selected points in the bese notal and weldnent rogions of the different opecineas and on the orerall surfece strains for etlected specicens.

Ker words: Welowents, creep-2upture, blgh-texperature desion, pressurized cylinders, stainiess steel, Istir, structurni tests.

\section{IrIRODUCTIOA}

The extensive use of welded stainless eteel pressure vessels and piping at tengeratures within the creep range matres an increased understanding of the time-dependent deformation and iallure behavior of weldvouts. A weldent in this context is const.derg: to be the depseited weld and a refon of base netal around the weld whe.se behavior is influenced by the presence of the weld. The properties of neldaents vary wldely due to difsuraces in weld procedures, weld netals, and weld gecnetries. The deelga ruzes for muclear composents s'obricated from autenitic stainlese steels to operate at temperatures above $427^{\circ} \mathrm{C}\left(800^{\circ} \mathrm{F}\right)$ pernit the use of 


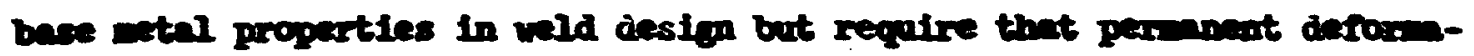
than be lifited to are-bale that ellowad for bese netal. Such rules do

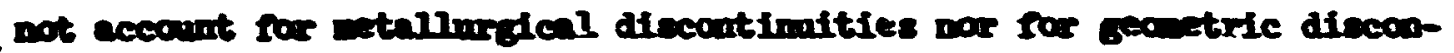
tinfities that as be introduced throngh difrerences in inslastic dercernution behwice of the base and weli extal.

Ints report pereate the reaults of a sectes of ereap-rupure tects of type 304/308 stainiess eteal veld ante. The peingy objective or thase

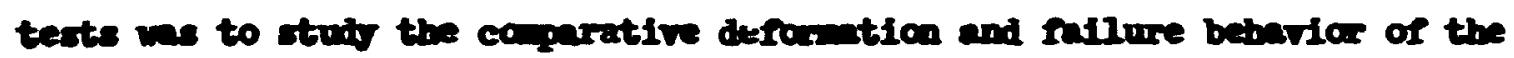

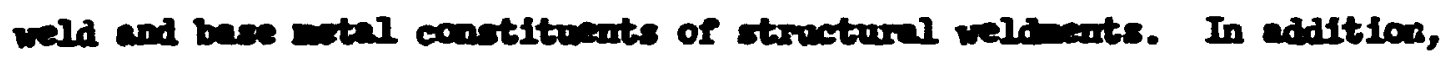

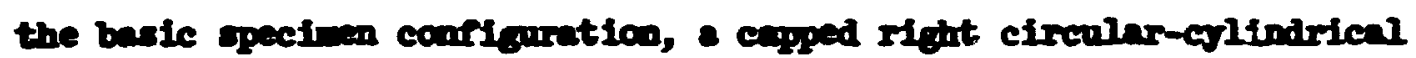

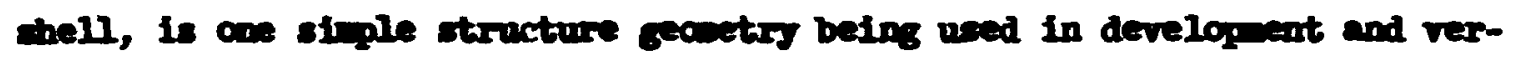
ifleation of inelnatic structurel amlysis nethods."

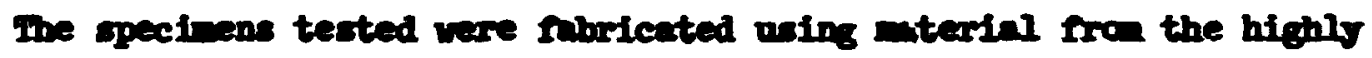

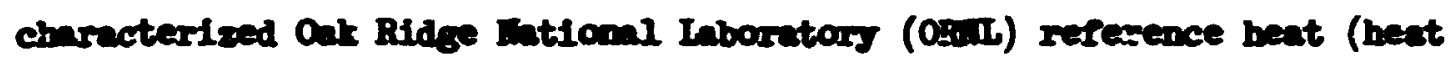
91279) of type 304 stafnless steel. The welds rere deposited in altiple passes using bare ijpe 308 stainless steel wire and the tungoten are (TIG) welaing procese.

The teats were coniucted in as at $593^{\circ} \mathrm{C}\left(1100^{\circ} \mathrm{F}\right)$. Tro series of .

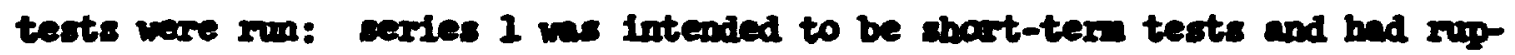
towe tives Irom 35 to $408 \mathrm{hr}$; series 2 wa deslgoed and tected to schieve longex 1 fretines and had rupture times 1100475 to $972 \mathrm{hr}$.

A pattern of scribe lines on the cylinder and cep of each gpecinen

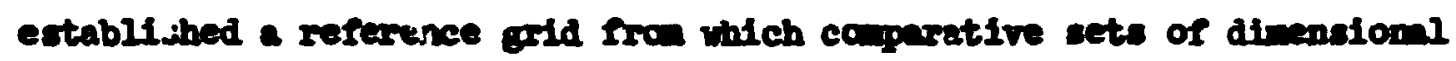

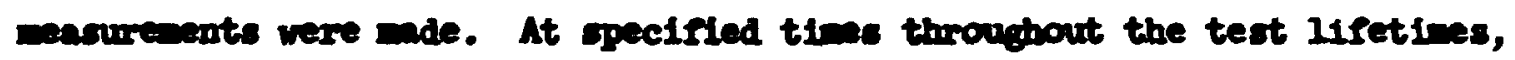
each ppacinen was depressurtaed, cooled, and rusoved from the furnace for

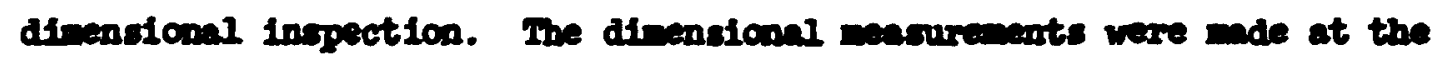
radial and axial locations of the nodes of the reference arid. The nodal locations rere used to dexnribe, through least-squares fitting, menent1-

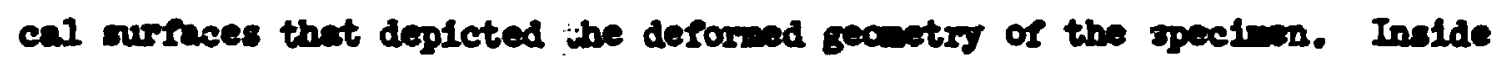

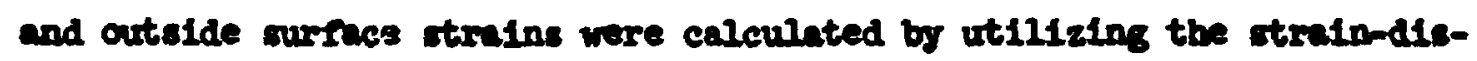
plecement relationhips of contimum mechnoics and the equation of thinsbell ansyeis epplied to the mathometical descriptioss of the defornd arrinces.

gection 2 of this report describes the deston and fublestion of the test specimen. Section 3 diecuress the tert facility, tent procedures, 
and test histories. Section 4 presents the deformtion date and the techniques used to convert these data to totwl inelastic strain. Section 5 is a sanary of results and the subsequent cosclusions. An appendix is included that contafins experibental surfuce strain distwibutions for selected times in the lives of dirrerent specimens. 


\section{TESI SFECFIS}

\subsection{Test Specinen Design and Pabrication}

Two saries of specinens were prepared for testing. These were desisnated as the veldwent creep-rupture 1 (WCR-1) series and the velonent creep-rupture ${ }^{2}$ (WCR-2) series. The WCR-1 series was intended to investigate veldment deformation and failure for times of $1000 \mathrm{hr}$ ar less. In addition, the inforwation and experience gained from testing this series of specimens were to provide guidance in the destifn of ICR-2 series specimens. The HCR-2 series specimens vere to be essentially of the same configuration as WCR-1 specimens tist were to be tested under conditions yielding failure times of approximately $8000 \mathrm{hr}$. For the WCR-l specimeus, the von kises effective stress was used as the failure criterion. This was based on the results of Anderson et al., which indicated that at $593^{\circ} \mathrm{C}\left(1100^{\circ} \mathrm{F}\right)$ pressurized tube failure data on annealed type 304 stainless steel correlated better with the von Mises rather than the maximum principal stress failure criterion. However, the failure results from WCR-1 specimens correlated best with the maximm principal stress failure criterion. Thus, this criterion was used in the design of the WCR-2 specimens.

In each series of specimens, the intent was to investigate the comparative behavior of base metal and deposited weld metal subjected to different stress or strain fielas. The specimens were thus to have welds located in different areas where each weldment was duplicated by an unwelded "control," generally as part of another specimen.

\subsubsection{WCR-1 specimens}

The besic specimen configuration to be tested was thin-walled right circular cylinder with a flat head. The nominal diameter was chosen to utilize product forms from the ONwl reference heat (hent 912796) of type 304 stainless steel. These product forms vere 114-mm-diem (4.500-in.) bar and 102-mo (4-in.) sched-160 pipe. The chemical compositions5, 6 of these two product foriss, as determined by ladle, check, and urkl analyses, are given in Table 1. 
Table 1. Cherical caposition (vt \$) of product fors of thre 304 stainless steel ('eat 912796) used for WRR-1 specinens

\begin{tabular}{|c|c|c|c|c|c|}
\hline \multirow{2}{*}{ Blerent } & \multirow{2}{*}{$\begin{array}{c}\text { Iadle } \\
\text { andrsis }\end{array}$} & \multicolumn{2}{|c|}{$124-m$-dien bur } & \multicolumn{2}{|c|}{ sched-160 pipe } \\
\hline & & $\begin{array}{l}\text { Vendor } \\
\text { andrsis }\end{array}$ & $\begin{array}{c}\text { Opute } \\
\text { analysis }\end{array}$ & $\begin{array}{l}\text { Vendor } \\
\text { analrsis }\end{array}$ & $\begin{array}{c}\text { Ordu } \\
\text { analysis }\end{array}$ \\
\hline c & 0.048 & $\mathbf{M}$ & 0.039 & 0.046 & 0.039 \\
\hline in & 1.22 & IA & 1.31 & 1.23 & 1.31 \\
\hline $\mathbf{P}$ & 0.028 & $\mathbf{m}$ & 0.028 & 0.026 & 0.028 \\
\hline $\mathbf{S}$ & 0.015 & $\mathbf{L}$ & 0.014 & 0.020 & 0.014 \\
\hline $\mathbf{S 1}$ & 0.48 & m & & 0.50 & 0.42 \\
\hline $\mathbf{H I}$ & 9.70 & $\mathbf{M A}$ & 9.64 & 9.58 & 9.64 \\
\hline Cr & 18.60 & $\mathbf{M}$ & 18.54 & 18.57 & 28.54 \\
\hline Mo & 0.32 & $\mathbf{M}$ & 0.32 & $\mathbf{E A}$ & 0.32 \\
\hline $\mathbf{R}$ & IA & $\mathbf{R A}$ & 0.027 & $\mathbf{R A}$ & 0.027 \\
\hline $\mathrm{Cu}$ & 0.24 & RA & & $\mathbf{R A}$ & 0.30 \\
\hline Sn & 0.015 & $\mathrm{MA}$ & & $\mathbf{M A}$ & Hin \\
\hline $\mathbf{T I}$ & 0.010 & KA & & $\mathbf{R A}$ & $>0.01$ \\
\hline Co & 0.18 & $\mathbf{K A}$ & & $\mathbf{M A}$ & 0.20 \\
\hline
\end{tabular}

The basic spectmen wall thickness was set as $5.08 \mathrm{~mm}(0.200 \mathrm{in}$.). This dimension was established as a coupromise betreen several factors. A thin wall was desirabie for the tubular structure to behave as a thin shell and required less internal pressure to achieve the high stress levels required. However, a wall of 8 ign'ficant thickness was desirabl s. that a composite weld structure, that is, a weld couposed of several reldIng passes, would be tested. The possibility of premature failure through undetected microscopic flars in the veld would thus be mintinized.

With tine nominal wall thickess fixed, elastic analyses were performed using different bead-to-thickness ratios to investigate the general stress magnitudes and distributions in the cylinder, bead, and cylinder-to-head function region. The model used for these calculations was a right circular 
cilinder with a circunferential weld at the cylinder nidpoint. The crlinder ws closed at one end with a Nlat head and was built in of the other end. The results of these calculations vere used as a basis for selecting the head-to-arlinder thialmess ratio such that the calculated madiun effective elnatic stress in the center region of the isead was comparable to the effective elastic stress in the morane region of the cylinder. No exnct coparison could be ade since the stresses in the head varied with radial position. The calculated stress distribution in the cylinder was used as a basis for adjusting the spectien length to provide a region of nobrane stress between the circurerential weld and each end of the cylinder. These regions of nebrane stress were intended to isolate each discontimuity region from the influence of other regions. The above analjees indicated that a head-to-cylinder thickness ratio of $2: 1$ would jield comparable mading elastic stresses in the head and cylinder and that a length of 2 to 3 discters between discontimities would be sufficient spacing to provide undisturbed nembrane regions.

Test welds were to be located in three different test areas of the structures. The first area was circunferentially in the membrane region of the cylinder which would be typical of a pipe butt weld. For the internal pressure loading only, the applied membrane stress field had a 2:1 biariality ratio. The second area was the junction region between the head and cylinder. The weld in this regic 1 was intended to be in a fleld of high bending stress. Also, due to the bending and the constiraint of the bead, the naximin strain would be in the axisl direction transverse to the weld. The third test area was in the head of the specimen; the Intent was to locate a test weld in a stress field that would approach a 1:1 biaxiality ratio. The reld would be subjected to bending stresses parallel and transverse to the weld direction.

The WCR-1 series cunsisted of three spectmens; these are shom in P18. 1, along with the locations of ewch test weld. Specimen 1-MI had a weld in the cylinder-to-bead junction ragion with no welds in the membrane stress region of the cylinder. The cylinder thus served as the control for the circumerential pipe butt weld. The cylinder vas machined from pipe, and the Nat head was machined from bar stock. Specimen 2-Mn had a pipe butt weld in the cylinder; the upper half of the specimen ras machined 


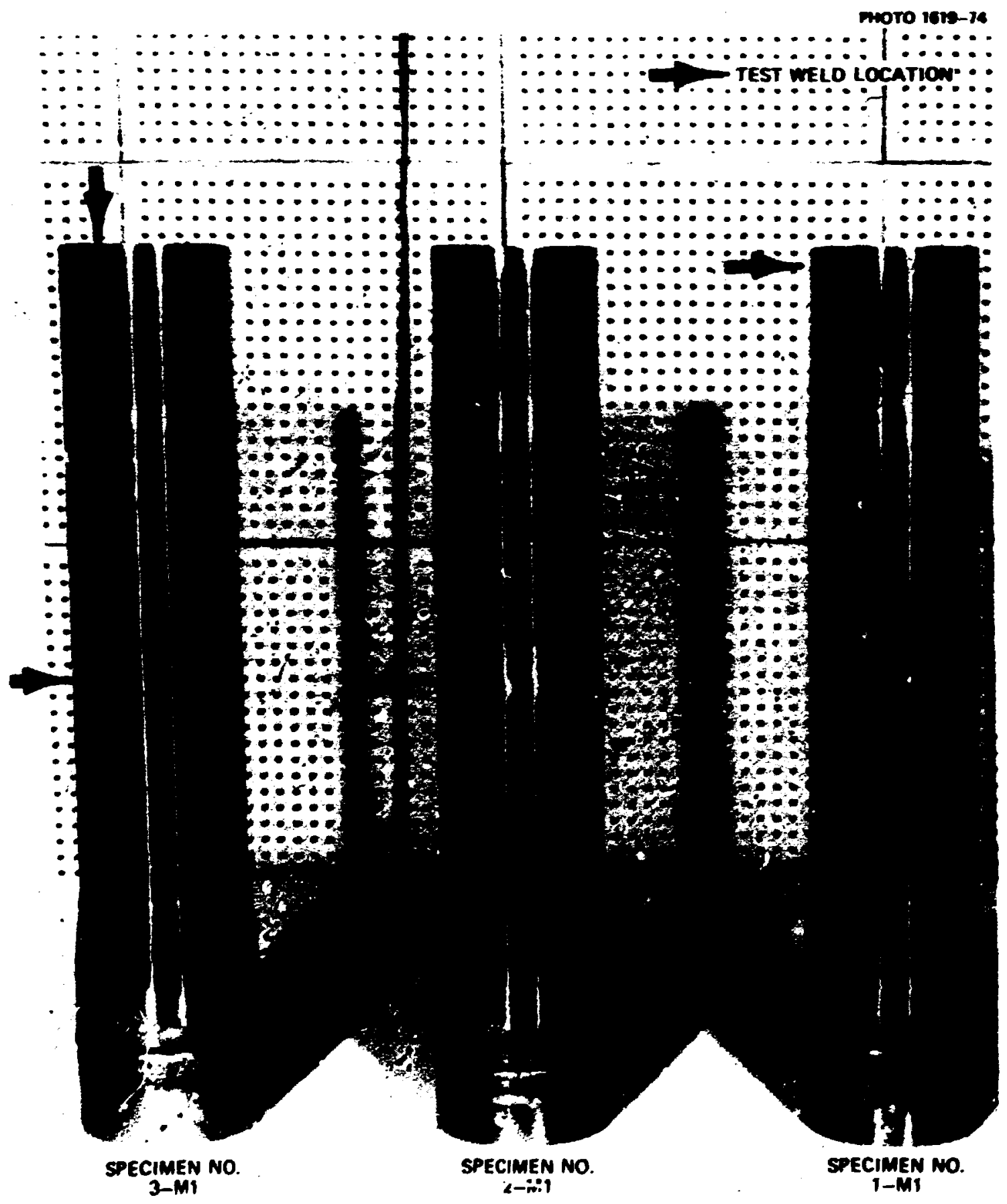

Pig. 1. WCR-1 specimens showing test weld locations.

from solid bar stock, and the lower cylinder region was made of pipe. The upper part of this specimen server as a control for the behavior of the weld in the cylinder-to-head junction region and for the weld in the head. Specimen 3-M had a circumferential weld in the head and a pipe 
butt wold in the cylinder. The upper part of this specinen wes enchined

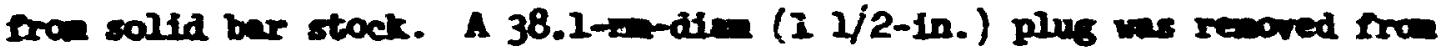
the center of the bead, the edges of plug and bead were mohined to the correct geonetry, and the plug wes relded back into the head to yield the desired circuiferential weld in the head. The lower part of this specimen wes ande of pipe nterial.

To control the feometric mariables that affect weld behavior, the specinens were mahined wooth after welding to rewore the drawdow of the veld region and the surpace discontionity of the weld bead. Also, the specimens were annealed prior to velding using the ocull leference ancel. 7

To prevent excess distortion during welding and to provide adequate naterial for mahining of the final specinen gecoetry, sections thicker than those proposed for the $\mathrm{finel}$ specinens were required. The crlindrical sections of the specimens were mchined to a $\omega .2-m(0.400-i n$. thickness, and the heads were machined to a $11.4-m(0.450-$ in.) thichess. The veld aurfaces were propared in this nachining step. The specinen parts vere annealed in argon using the reference anneal. Figure 2 shows a specimen. 4-12, from the secosd series of specinens that typifies this stage of preparation. The weld surfaces were cleaned by steel brushing and the parts vere velded together into the required asseblies.

These welded specinens were machined to the final disensions and configuration. It was found that the amount of drandown in the head weld of specinen 3-kn and in the pipe butt weld of specinens 2-th and 3-10 required remoring nore material than was originally anticipated. While this did not modify the basic specinen geanetiy, it did cause nnor changes in dimensions. The Iinal specimen wall thickness becine $4.52=(0.178 \mathrm{in}$.$) ,$ the head thichess was $7.62 \mathrm{~mm}(0.300 \mathrm{in.})$, and the outside dineter wes $0.103 \mathrm{~m}$ (4.050 in.). After finish wahining, the outside surfaces of the specimens were lightly polished, and circumferential scribe linso epproximately $0.025 \mathrm{mon}(0.001 \mathrm{in.})$ deep were machined at specifled locations on the cylinder and head. These lines, which are visible in Pig. 3, were used as part of a reference grid for maring dimensional measurements. The axial spacing of the lines on the cylinder was nominal2y 25.4 . 


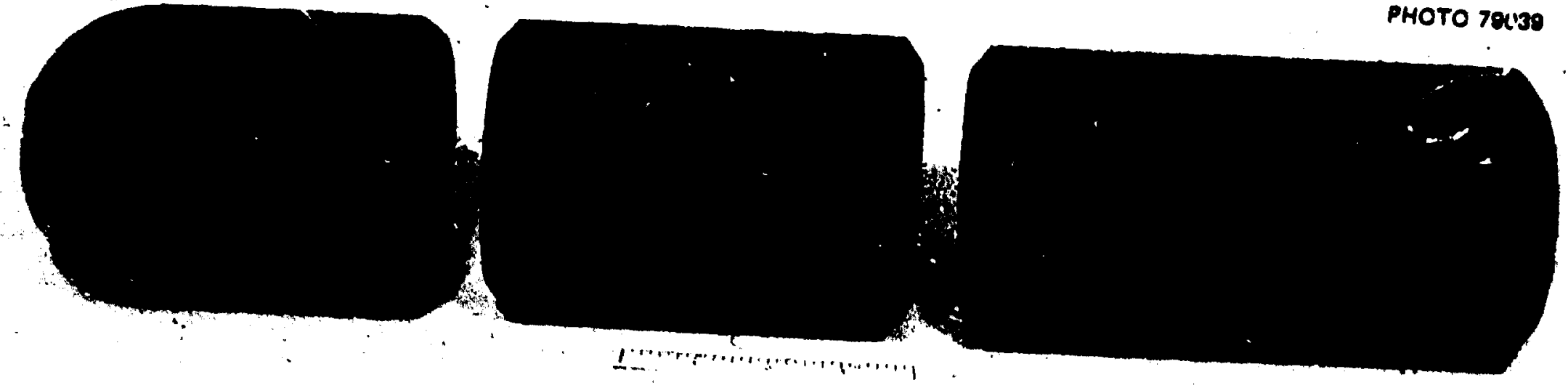

Fig. 2. View of weljment creep-rupture apectmen that typifiea conaition of all specimens after preparatory machining and annealing. 

(1 in.) but was reduced to $6.35=(1 / 4$ in.) in regions, such as the colinder-to-bead juaction region, were variatiops in the strain distribution were expected. The scribe lines on the head were concentric circles with their center being the gecunetric ceater of the bead. The dianeters of these circles ranged fro $12.7=(1 / 2$ in.) to $88.9=(31 / 2$ in. $)$ in $12.7-=$ (1/2-in.) increments. These lines were used in data acquisition, es discussed in detail in section 4.

The radicgraphic inspection of the pipe buct reld of epecinen 2-10 revealed deposits of high-density material in the root pass of the weld. These deposits vere tentatively identified as boron, and the size and nuber were bases for the weld failing to pass the required inspection. luring the subsequent weld rewoval, weld surface preparation, and revelding, it was necessary to renove a region of base wetal on each side of the weld, alang with the weld. Thas, the final overall lengih of speciwen 2-M was about 25.4 m ( 1 in.) shorter than the other two specimens. This was not considered to be a probles since there was an adequate region of membrane stress between the pipe butt weld and each end of the specimen.

A schematic of an assenbled specimen is shown in Pig. 4. A carbon steel core was used for inside filler, and the specimen was closed using

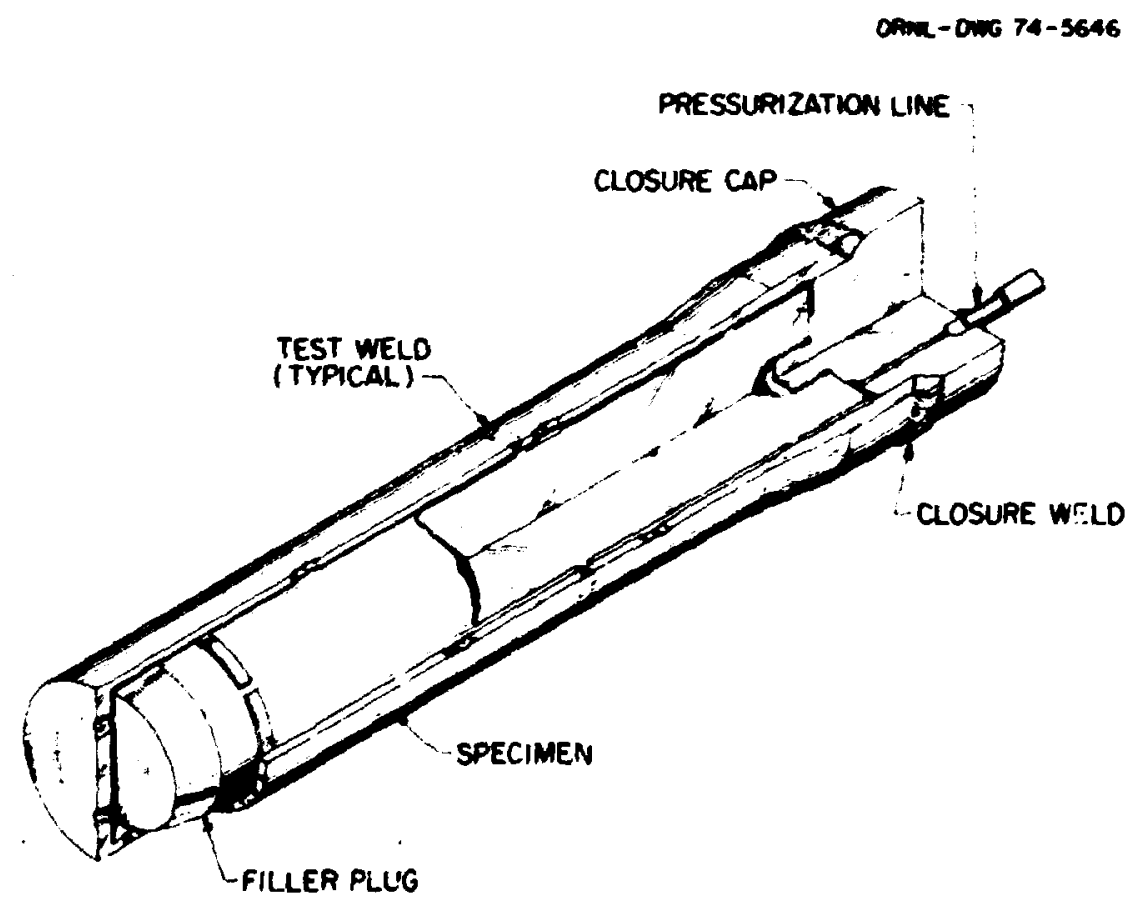

F18. 4. Schematic of a typical weldment creep-rupture assembly. 
a rairy hears cylindrical cap. The core was mahined to a $1.27-20$ (0.05in.) clearance with all inside surfuces of the specinen and displaced approximtely $80 \%$ of the gas volune. The closure cap was designed to provide a relatively rigid base for the cylindrical section of the test specinen. This cap was mie of type 304 stainless steel and was welded ;0 the spectren using the sane weld rod and velding procedure that was used for the test welds. The cap also served to support the specimen core through a threaded connection as shom in Fig. 4 and to properly align the care with the specisen such that contact of the two was prevented. Two 2.33-m-dian (3/32-in.) holes with centers on a 61-madian (2.4-in.) circle were drilled axially through the cap. The outer end of each hole was mahined for autoclave fittings. One of these fittings was somected to the pressurization line, while the other was attached to a short length of high-pressure tubing that extended outside the furnace and ended in a val-re. This line wes used for venting the specimen during gas purging and pressure release. Due to problems encountered in maintaining the integrity of the seals between the pressure tubing and the specimen, the autoclave fittings were later renoved and the tubing was welded directly to the specimen. A 12.7-min-diam (1/2-in.), 22.2-m (7/8-in.) deep hole was drilled and tapped in the center of the outside end ne the cap, and a threaded rod, by which the specimen was suspended in the furnace, was screwed into this hole. These details are shown in Fig. 4.

Axial reference lines approximately $25.4 \mathrm{~mm}$ (1 in.) long were scribed at $60^{\circ}$ increments around the circunference of the closure cap. The lines were not scribed along the entire length of the specimen since there was a possibility that such axial scribe marics on the test section would serve as stress raisers that might lead to premature specimen failure. These Iines were identifled as A-F using metal indentation stamps in order to provide permanent markings for reference purposes. Thege arial scribe Iines, in confunction with the sircumferential scribe Iines on the specimen, were used as part of the gili for data acquisition which is discussed in detail in Section 4.

\subsubsection{HCR-2 specimens}

The secord series of weldment creep-rupture specimens (HCF-2) were essentially the same gecmetrically as the first series. By allowing more 
mterial during the internediate mchining steps, the restrictions on opecinen dinneter and thickness cuused by weld drandown were overconc. The noinal dinensions of the WCR-2 specinens were: dianeter, $0.102 \mathrm{~m}$ (4 in.); well thickness, $5.08 \mathrm{~m}$ (0.2 in.); and head thicloness, $10.2=$ (0.4 in.). A 4.8-a (3/16-in.) radius flllet was added to swooth the transition from the cylinder to the head. The sme schene of product form usage and weld locetion as for the MCR-1 specinens was used. To ref..ct this contimity, the WCR-2 specilens were given the sane mibers as the geonetrically sinilar ICR-1 specinens and subsequently the specinens were referred to as th (model 1) or H2 (model 2) specinens, respectively.

An additional specinen, a cylinder with a hesispherical cep, was introduced into the second series of tests. This specinen had two circucferential welds in the cylinder and one in the head. The weld in the head region would be subjected to equal biarial elastic stiresses in a comparatively uniform stress field. The thickness of the heulspherical section, which was machined from solid bar stock, was 2.92 man (0.115 in.) to yield the initial elastic maximu principal stress in the cap the same as that in the 5.08-m-thick $\left(0.2-1 n_{\text {. }}\right)$ cylinder region.

Figure 5 shows the set of WCR-2 specimens prior to testing. The 10cations of the test welds are indicated by the arrows. Note that, as with WCR-1 specimens, the surfaces were scribed to yield reference points for dimensional measurements.

\subsection{Description of Test Nelas}

The type of weld used for this set of specimens was selected on the basis of current (current at time of test program initiation) thinking for the Fast-Flux Test Facility (FPIP! pipe welds. For type 304 stainless steel pipe, type 308 stainless steel alloy weld rod and TIG relaing process was to be used. The pipe rould be mill annealed and no postweld heat treatment would be applied. The exact chemistry of the weld rod and rod couting had not been selected.

It was thus decided to use a high-quality weld procedure and bare type 308 stainless steel weld rod. The weld speciflcation used was ORLL Velding Procedure Specification WPE-302, which, for the veld gecmetries 


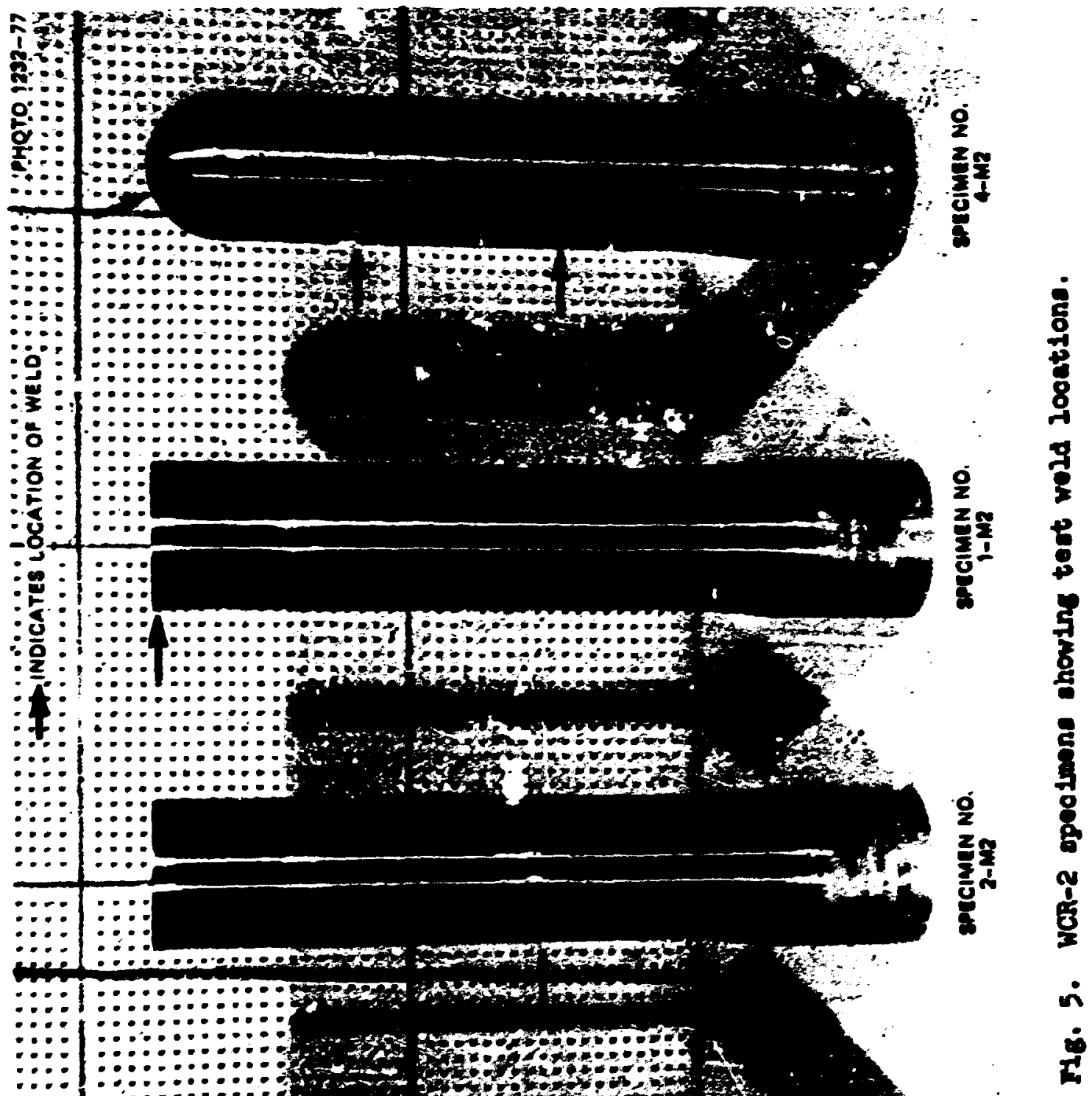


ased, is qualified to FWI F6-5 and is for the IIG process. These spectNicutions require dre-penetrant and 100 p radiographic inpection.

The weld geonetrles were of two types as shom in Fif. 6 . The single-U geonetry wh used fur the plog-to-bead weld of opecinens 3-11, 3-12, and 4-12. The single-V eecotory was ured for all other velds, including the specinen elosure wid. The veld rod used was bare tjpe 308 stainless steel in 1.59-m (1/16-in.) and 2.38-m (3/32-in.) dimeters. This rod

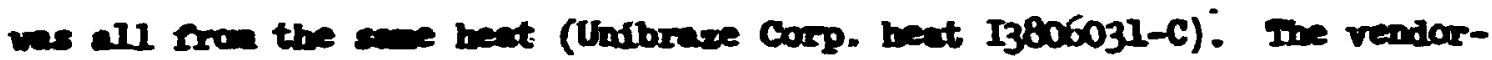

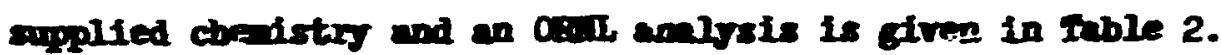

onm-0ns rz-cazen

\begin{tabular}{|c|c|c|c|c|c|c|}
\hline GAOOVE ITPE & \multicolumn{5}{|c|}{ GROOVE DIMENSIONS } & THCKNESS \\
\hline & D (b) & 6 (nol) & of (in) & go (in) & $R(\operatorname{lin})$ & (in) \\
\hline SIMGLE-V & $45=25$ & $90 \div 5$ & $\begin{array}{r}0.010 \\
=0.005\end{array}$ & $\frac{1}{16}-\frac{1}{64}$ & & $\begin{array}{c}0.100 \\
10 \\
0.300\end{array}$ \\
\hline RO-AL & $20 \div 25$ & $40 \div 5$ & $\begin{array}{l}0.062 \\
-0.016 \\
-0\end{array}$ & $\frac{1}{16}-\frac{1}{64}$ & $\begin{array}{l}0.099 \\
-0.016 \\
-0\end{array}$ & $\begin{array}{c}0.375 \\
10 \\
1.0\end{array}$ \\
\hline
\end{tabular}

Fig. 6. Neld geanetries used for weldent creep-rupture specinens. 
Table 2. Cheistry of type 308 stainless steel weld rod (Inibrese Corp. hent I3806031-C) used for test welds of laR-2 specinens

\begin{tabular}{|c|c|c|}
\hline \multirow{2}{*}{ Blement } & \multicolumn{2}{|c|}{ Amlvais (ut S) } \\
\hline & Vendor & and \\
\hline c & 0.07 & 0.026 \\
\hline In & $1.0-2.0$ & 2.10 \\
\hline $\mathbf{P}$ & 0.03 & 0.029 \\
\hline $\mathbf{s}$ & 0.03 & 0.0078 \\
\hline $\mathbf{s 1}$ & $0.25-0.60$ & 0.35 \\
\hline $\mathbf{E I}$ & $9.5-11.0$ & 11.98 \\
\hline $\mathbf{C r}$ & $20.0-22.0$ & 19.67 \\
\hline 1.0 & $\mathbf{M}$ & 0.048 \\
\hline $\mathbf{E}$ & $\mathbf{m}$ & 0.032 \\
\hline Cu & $\mathbf{m}$ & 0.06 \\
\hline $\mathbf{B}$ & $\mathbf{M}$ & 0.0005 \\
\hline $\mathbf{T I}$ & $\mathbf{m}$ & 0.005 \\
\hline $\mathrm{BD}$ & $\mathbf{M}$ & 0.0003 \\
\hline
\end{tabular}




\section{TEST FROCDDURES NID TEST hISTORIES}

\subsection{Deacription of rest Pecility}

A special test recility ws set up to sthd the creep-rupture behavfor of these weldments. Pour identicel test stands were prepared using a comban snrety enclosure es show in Pig. 7. A schenatic of a single test stand is shown in Plg. 8. The Nurnaces were cylindrical, electrically heated auffle furaces with a 0.3-a-dien (12-in.) by 0.81-10ng (32-in.) cority. When properly powered these furnaces hrve a terpercuture range fro roon teperature to $1010^{\circ} \mathrm{C}\left(1850^{\circ} \mathrm{F}\right)$. A steel liner composed of a $0.22-\mathrm{m}$ ( 8 I/2-in.) sched-80 pipe with a pipe cap welded to one end ma used to protect the furnace wall and heater elenents fros the potential darage of rupturing specinens.

Tenperature control ias provided by Brom Blectronik recorder-controllers, wich are paeusatic-type controllers with both manue? and autonatic control features. The instrumt output controlled a pnewnatically driven variable furnace power supply to mintain the specimen at the required set point. Since the furnace was greatly orexporered, the controller tended to sycle approxiately $\pm 2.8^{\circ} \mathrm{C}\left(5^{\circ} \mathrm{F}\right)$ throughout the test period. Trelve therncouples* were used; two were mounted in parallel near Nurnece midheight for temperature control, and ten vere installei at 50.8In (2-in.) increments along the vertical axis of the specinen. In preIininary tests of the furnace system, the readings fron these thermocouples indicated that the temperature dropped off rather sharply at each end of the rurnace such that the desired uniform distribution was not established. Triming heaters were thus installed at the top and bottom ends of the furnace cavity. These anall mamally adjusted heaters were used to balance the heat load to maintain a unfform heat distribution along the vertical axds of the specimen.

The specimens vere pressurized through a cownon manifold system connected to a 17.9-MPa (2600-psig) supply of bottled argon gas. Figure 9

*Chronel-Alumel, type K, 3.2-mm-diam (1/3-1n.), 304 stainless steel sheathed, $0.75 \%$ accuracy. 


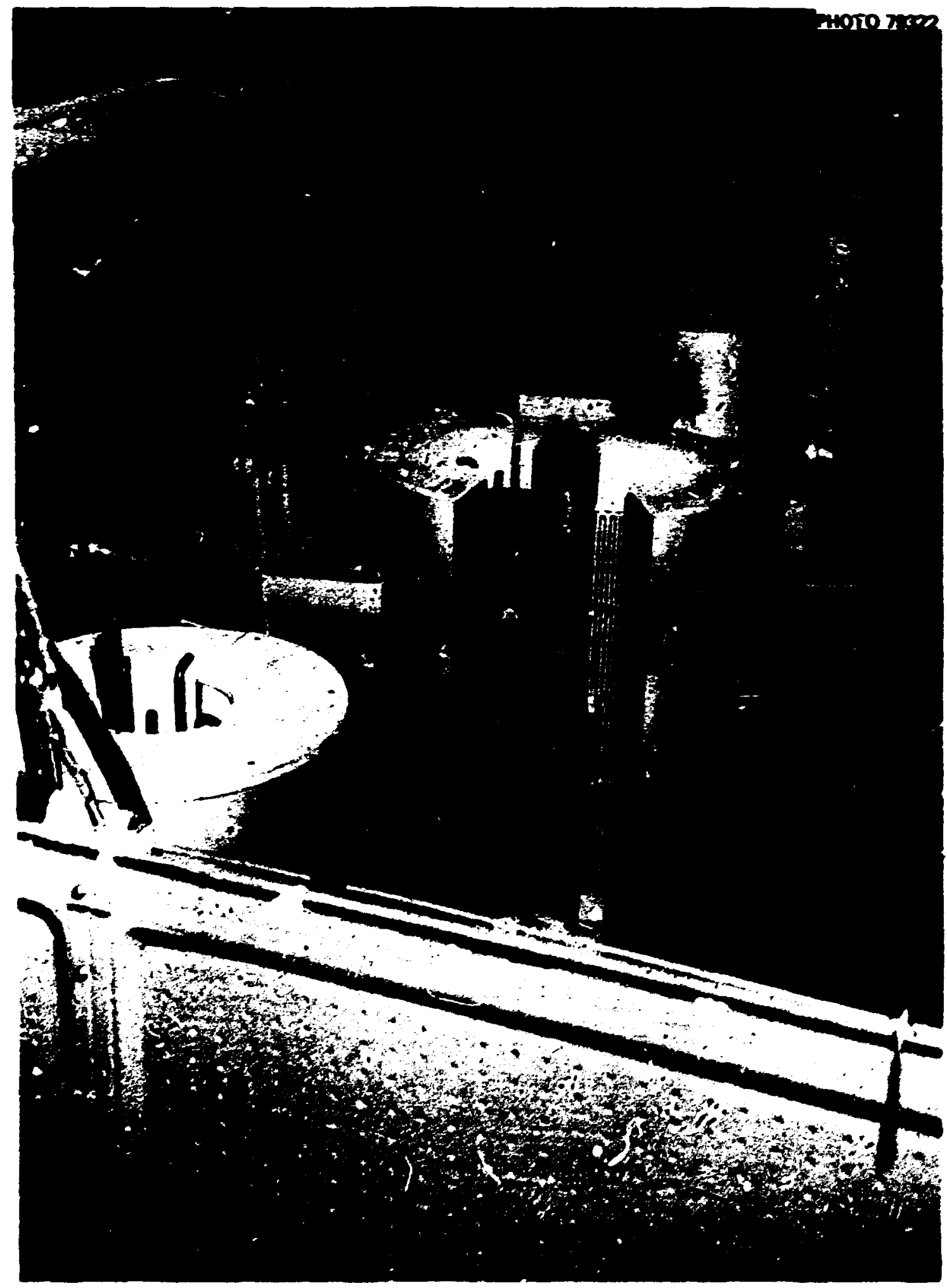

P1g. 7. Test stands and safety enclosure used for veldment creeprupture studies. 


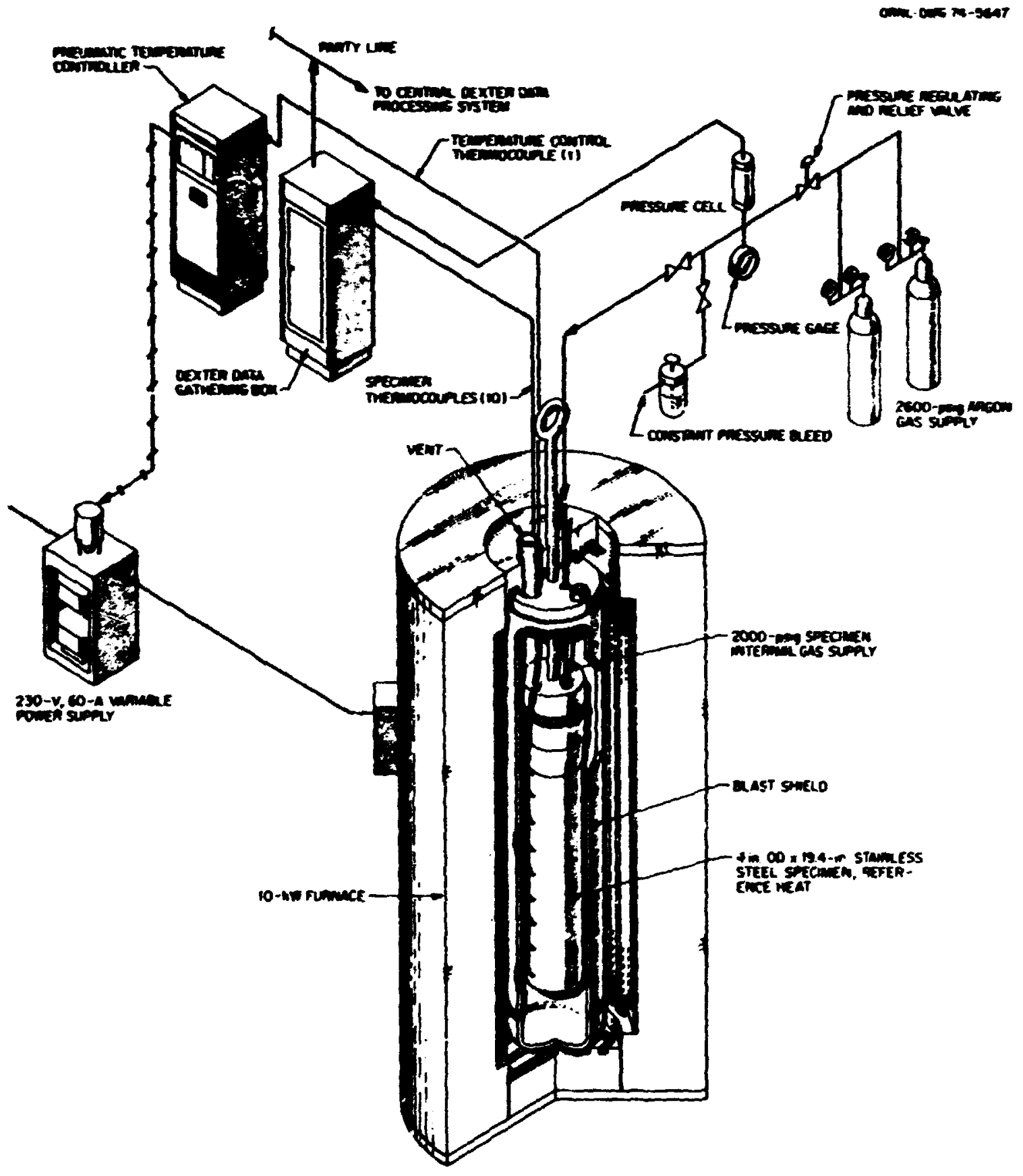

WELOMENT CAEEP RUPTUAE TEST FACILITY

P18. 8. Schematic of one of the weldment creep-rupture test stands. 


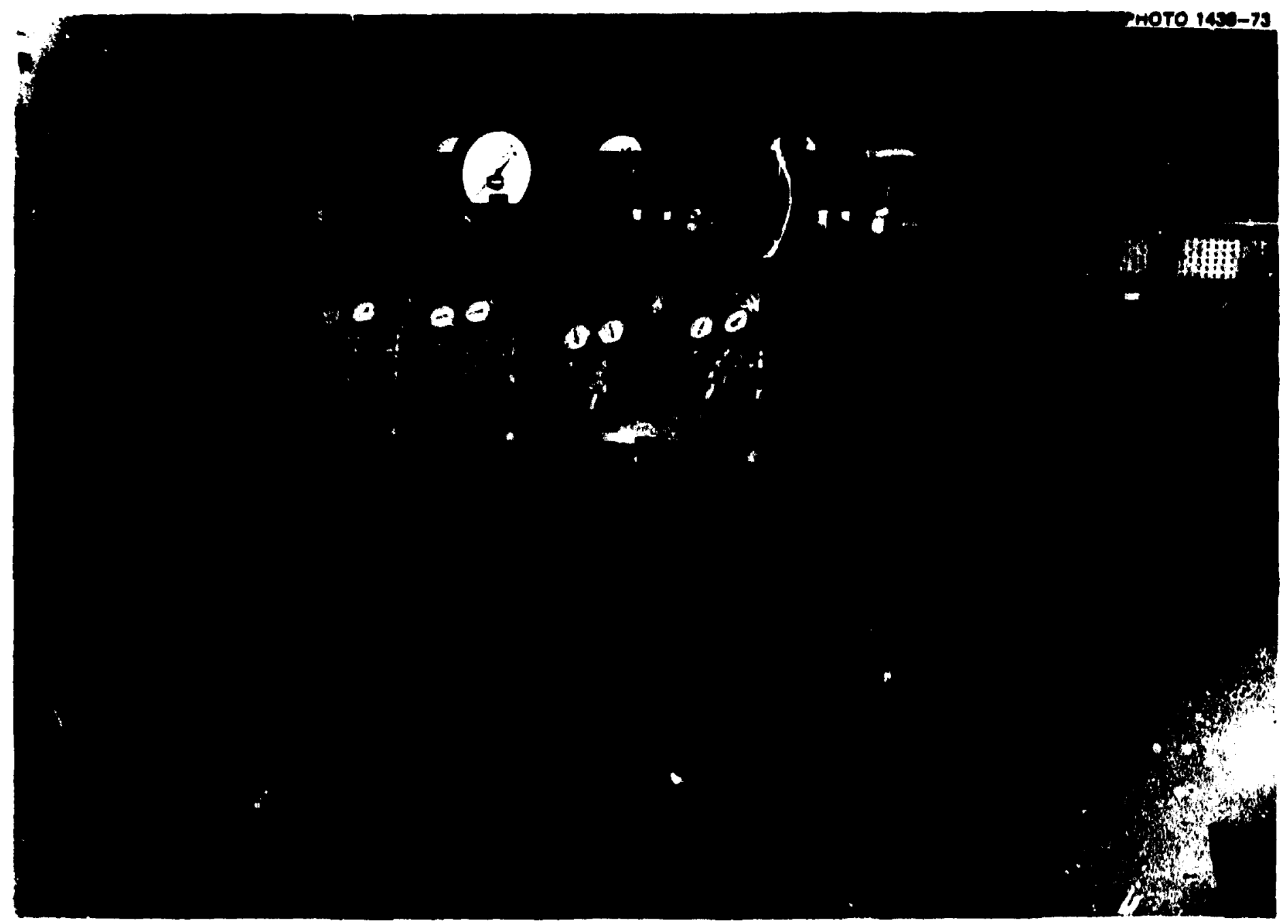

Fig. 9. Argon oupply aystam used in pressurising weldwent creeprupture apecimens. 
shows the ges supply systen, which includes: (a) a gas bottle and regulator; (b) a Grove now control valve, regulating and relief type; and (c) a Heise gage, which was used to calfbrate the pressure transducers. Figure 10 shors the matrold takeorf used to supply each speciven. Autocleve block valves were used to adjust the gas flow rate, a dial pressure indicator provided on-site monitaring of specinen pressure, and a Baldrin SR-4 pressure cell profided recote neasurenent of specinen pressure.

Figure 11 shows the control parel for the systen and the cabinet (door open) housing the on-site data-gathering box. Sigenls from the pressure transducer and the thencouples were passed through this assten to a central processing coplex where printouts of terperature and pressure vs time rere prepared.

\subsection{Test Procedure and Histories}

The initial part of each test run was devoted to checlirg and stabilization of systen parameters. For the initial loading of an undef(rmed specinen, the speciwen was purged slorly with argon (essentially atwo. spheric pressure) as the heat was applied. Unen the furnace reached noninal temperature, the mamal triming fenters were adjusted to establish a uniform temperature distribut:ion along the length of the specimen. The time required for this varied but was usually 24 to $36 \mathrm{hr}$. With the terperature stabjlized, the pressure was applied in predetermined stages from zero to full 10ad. The specimen was held briefly at each stage primarily to check for continuing lealtightness of the system. The hold time at each pressure level was afnimized in order to bring the spectmen to full load as quickly as possible. The total loading time usually was 10 to 30 min. Time zero was measured from the point where full load vas reached, after wich the pressure was held constant for the remainder of the test. A typical histogran 18 shom in Pig. 12 for specimen 2B-MA, which ruptured arter $181 \mathrm{hr}$ at rull pressure. The test duration was determined either by rupture or by achieving a specifled time in test where the specimen was unloaded, cooled, and renoved from the furnace for dimensional inspection.

The loading procedure was slightly different for a test that is a resumption of one that had been listermupted for dimensional inspection. 


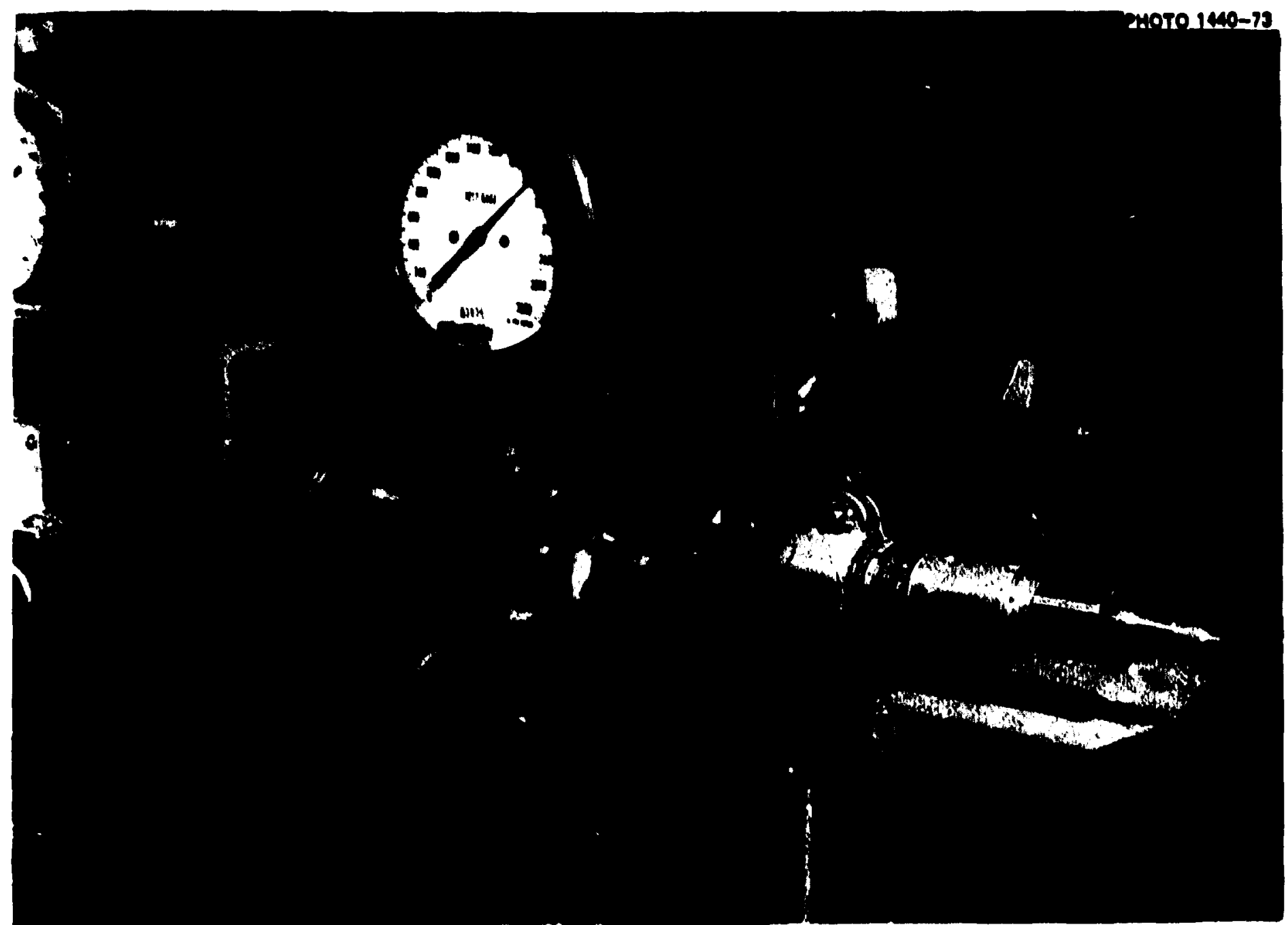

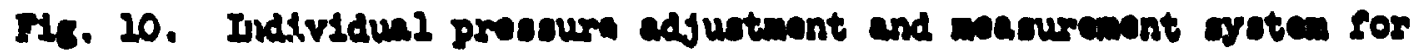
each widiont exvop-rupture opeoinan. 


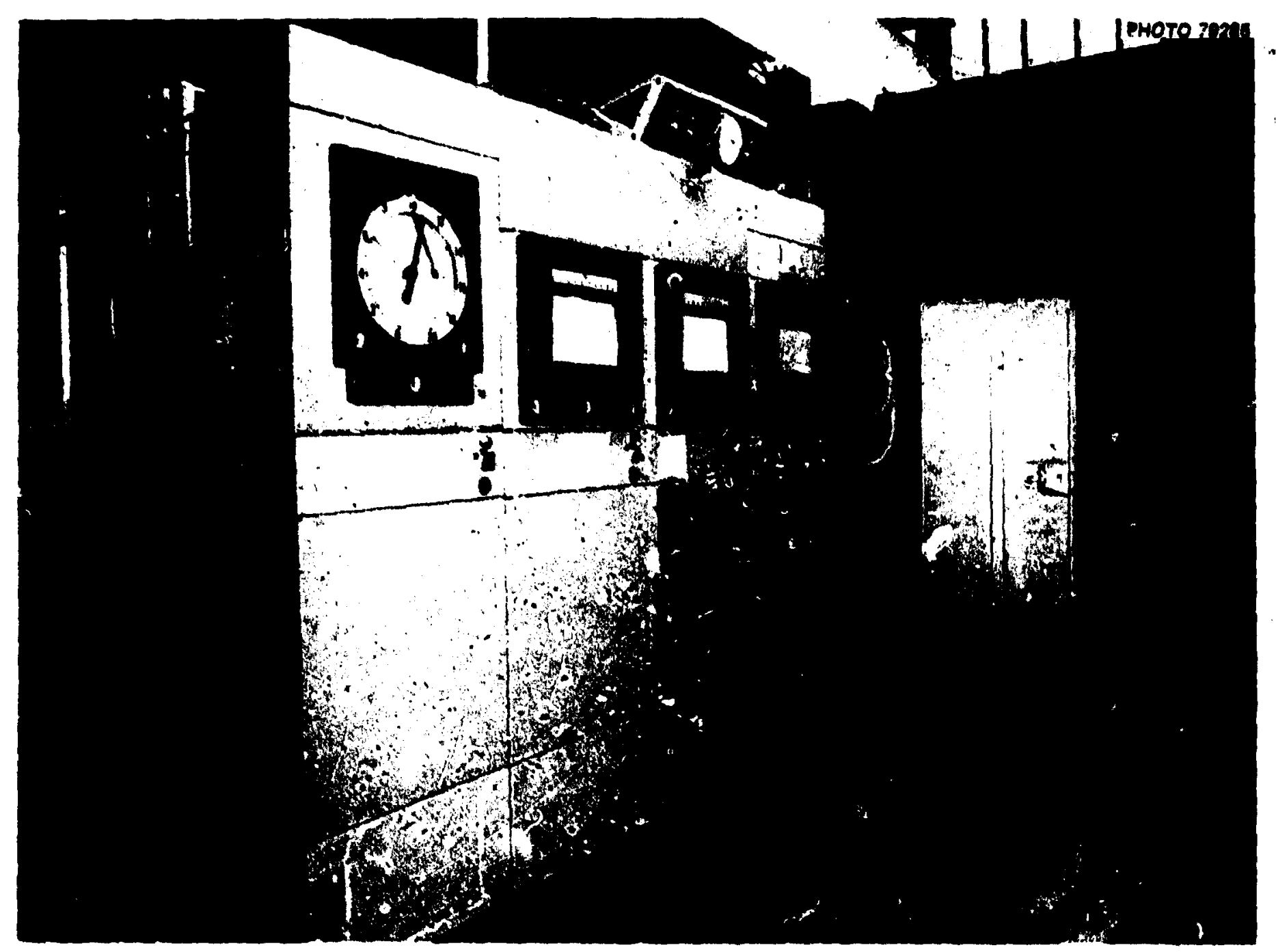

F1g. 11. Control panel and data acquisition ayotem for velomant creep-rupture tests. 
OANL-OWO 74-7MAG

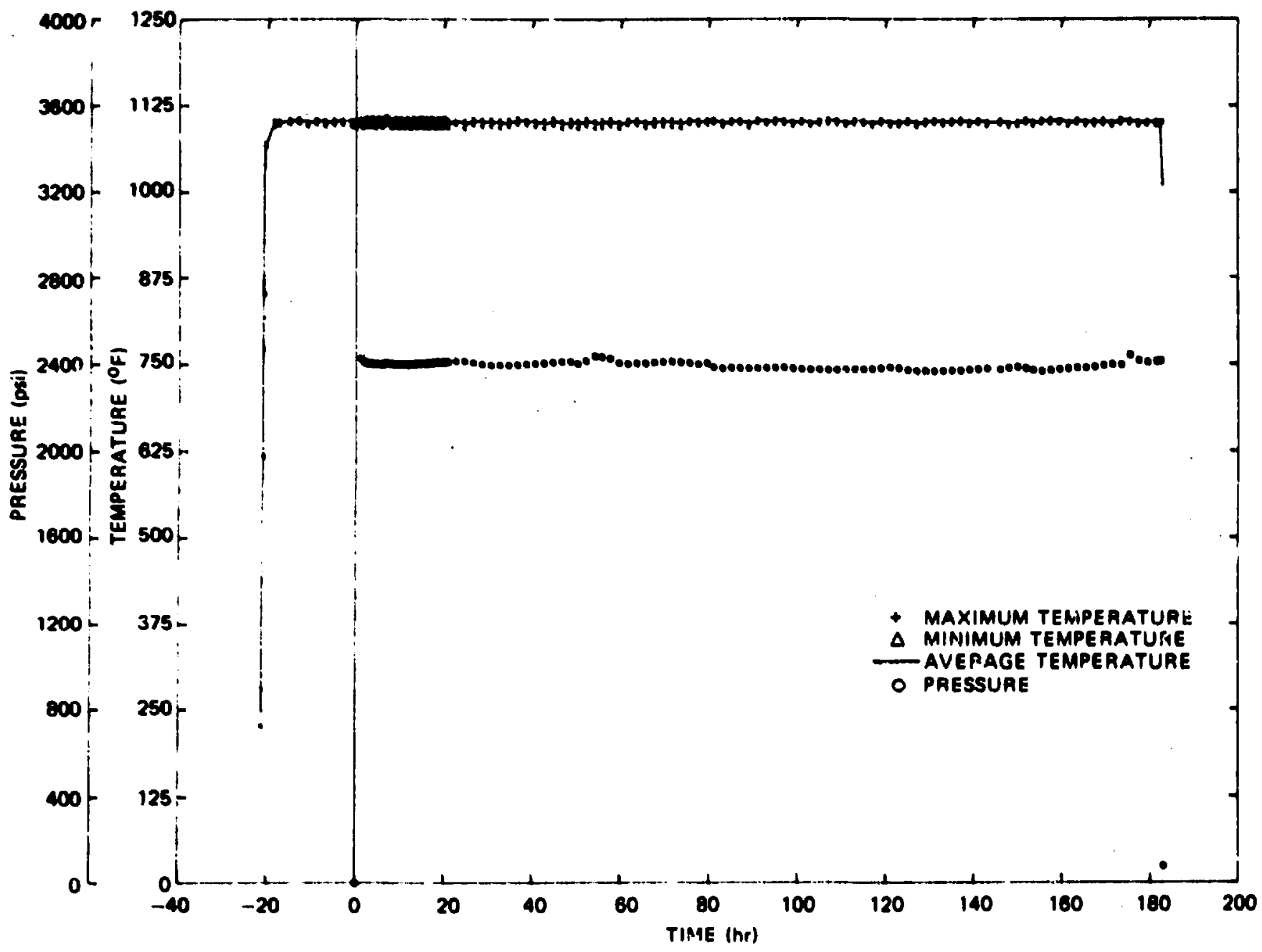

F18. 12. Typlcal histogram for a woldment creep-rupture apecimon. 
The specimen was first pressurized at room terperature to approximately balf the test pressure. Inis pressure was beld constant during rurnace beatup, syste chechout, and stabilization, at which tine rall pressure was applied and the test was continued. This technique, recomended by Yaggee et al., was intended to retain the nicrostructure carresponaing to the accrued strain history prior to interruption of the test.

In the following discussion of test histories, it will be belpful to refer to Table 3, which sumarizes specinen types, test conditions, and railures.

\subsubsection{Specien 1-12}

The test for this specimen was the nost straightfomard one of the first series of specimens. The spectwen was pressurized to $16.6 \mathrm{kPa}$ (2410 psig) for $408 \mathrm{hr}$, at wich tive rupture occurred by long axial creck in the cyindrical region of the specimen (see Pig. 13).

\subsubsection{Specimen 2-1n}

This specimen was tested at $16.6 \mathrm{MPa}$ (2410 psig) for $35 \mathrm{hr}$, when fallure occurred by complete separation of the flat head from the cylinder (see PIg, 24). There was eridence that the filler core had contacted the specimen cap and put an axial thrust on the cap. This would have caused the specimen to fall in a shorter time period than if loaded. by pressure alone. The specimen was thus rebuilt by (a) removing the ruptured end back to near midcylinder length; (b) reducing the length of the ftuler core by 13 (0.5 in.); (c) machining new cylinder and head (an integral piece) from bar stock; and (d) velding this to the exdsting specimen. This specimen, designated specimen $2 \mathrm{~A}-\mathrm{kn}$, was returned to test. After $88 \mathrm{hr}$, fallure occurred by head-to-cylinder separation as with 2-16. The ruptured area of specimen 2A-kl was sealed by welding a flat circular disk to the cylinder. This specimen, desigonted specimen $2 B-1 \mathrm{~L}$, was tented for an additional 123 br before fallure occurred by an axial crack. in the cylinder portion of the original specimen 2-in (1.e., this section failed after a time in test of $304 \mathrm{hr}$ ). The type of faliure is shown in F18. 15. 
Table 3. Sumaxy of weldment creep-rupture specinen biatories
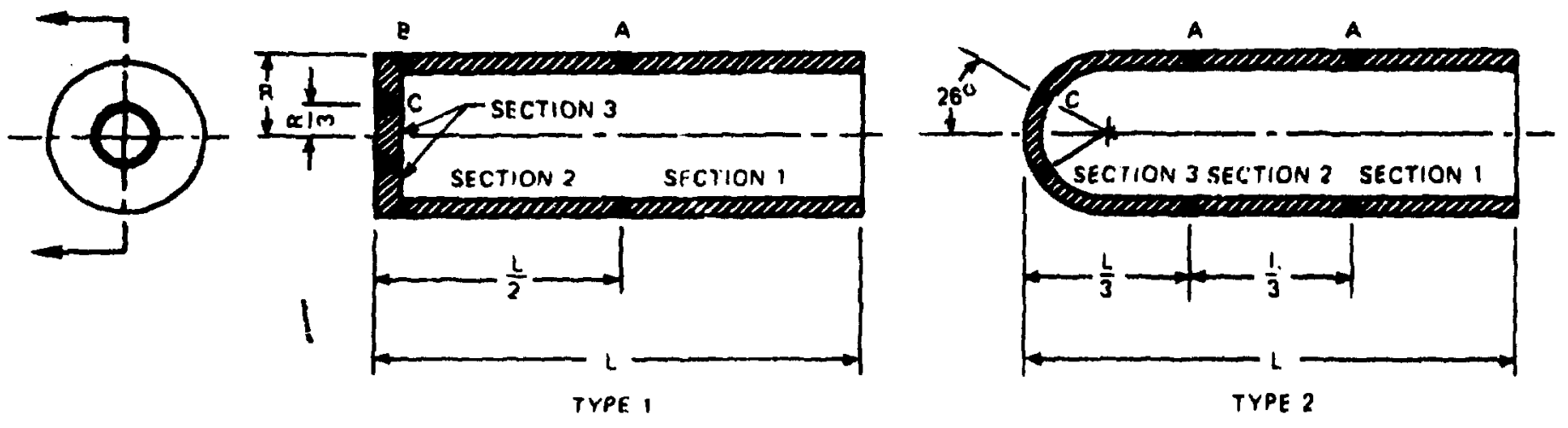

NOMINAL DIMENSIONS $L: 0.51 \mathrm{~m}(20 \mathrm{in}) R=.51 \mathrm{~mm} 120 \mathrm{~m}$.

A. B. AND C DENOTE TYPICAL WELO LOCATIONS

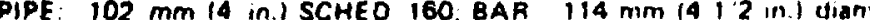

TEST TEMPERATURE. $593^{\circ} \mathrm{C}\left(1100^{\circ} \mathrm{F}\right)$

\begin{tabular}{|c|c|c|c|c|c|c|c|c|c|}
\hline \multirow{2}{*}{$\begin{array}{c}\text { Specimen } \\
\text { No. }\end{array}$} & \multirow{2}{*}{ Type } & \multicolumn{3}{|c|}{ Mater1al } & \multirow{2}{*}{$\begin{array}{l}\text { Weld } \\
\text { locetions }\end{array}$} & \multirow{2}{*}{$\begin{array}{l}\text { Test weld } \\
\text { locations }\end{array}$} & \multirow{2}{*}{$\begin{array}{l}\text { Pressure } \\
\text { (MPa/ps18) }\end{array}$} & \multirow{2}{*}{$\begin{array}{l}\text { Tlme } \\
\text { (hr) }\end{array}$} & \multirow{2}{*}{ Fallure mode } \\
\hline & & Section 1 & Section 2 & Section 3 & & & & & \\
\hline $\begin{array}{l}1-M a \\
2-M a \\
(2 A-M a) \\
(2 B-M Q) \\
3-M a \\
(3 A-M a) \\
1-M Z \\
(2 A-M 2) \\
2-M 2 \\
3-M 2 \\
4-M 2\end{array}$ & $\begin{array}{l}1 \\
1 \\
1 \\
1 \\
1 \\
1 \\
2 \\
1 \\
2 \\
1 \\
2\end{array}$ & $\begin{array}{l}\text { Plpe } \\
\text { PIpe } \\
\text { Pipe } \\
\text { PIpe } \\
\text { PIpe } \\
\text { Plpe } \\
\text { PIpe } \\
\text { Plpe } \\
\text { PIpe } \\
\text { Pipe } \\
\text { Plpe }\end{array}$ & $\begin{array}{l}\text { Plpe } \\
\text { Bar } \\
\text { Bar } \\
\text { Bar } \\
\text { Bar } \\
\text { Bar } \\
\text { PIpe } \\
\text { Pipe } \\
\text { Pipe } \\
\text { Bar } \\
\text { Plpe }\end{array}$ & $\begin{array}{l}\text { Bar } \\
\text { Bar } \\
\text { Bar } \\
\text { a } \\
\text { Bar } \\
a \\
\text { Bar } \\
\text { a } \\
\text { Bar } \\
\text { Bar } \\
\text { Bar }\end{array}$ & $\begin{array}{l}B, \\
A, \\
A, C \\
A, B \\
A, C \\
A, B \\
B \\
B \\
A \\
A, C \\
A, C\end{array}$ & $\begin{array}{l}\text { B } \\
A \\
C \\
\text { None } \\
A, C \\
A \\
B \\
\text { None } \\
\text { A } \\
\text { A, C } \\
\text { A, C }\end{array}$ & $\begin{array}{l}26.6 / 2410 \\
16.6 / 2410 \\
16.6 / 2410 \\
16.6 / 2410 \\
16.6 / 2410 \\
16.6 / 2410 \\
14.1 / 2040 \\
14.1 / 2040 \\
14.1 / 2040 \\
14.2 / 2040 \\
14.1 / 2400\end{array}$ & $\begin{array}{r}408 \\
35 \\
68 \\
181 \\
43 \\
153 \\
475 \\
3576 \\
3996 \\
9712 \\
1136\end{array}$ & 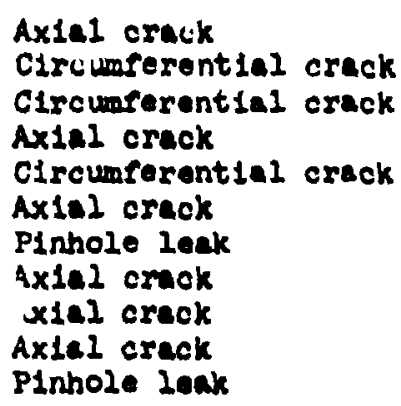 \\
\hline
\end{tabular}

plate naterial used for closure only, not reference heat. 


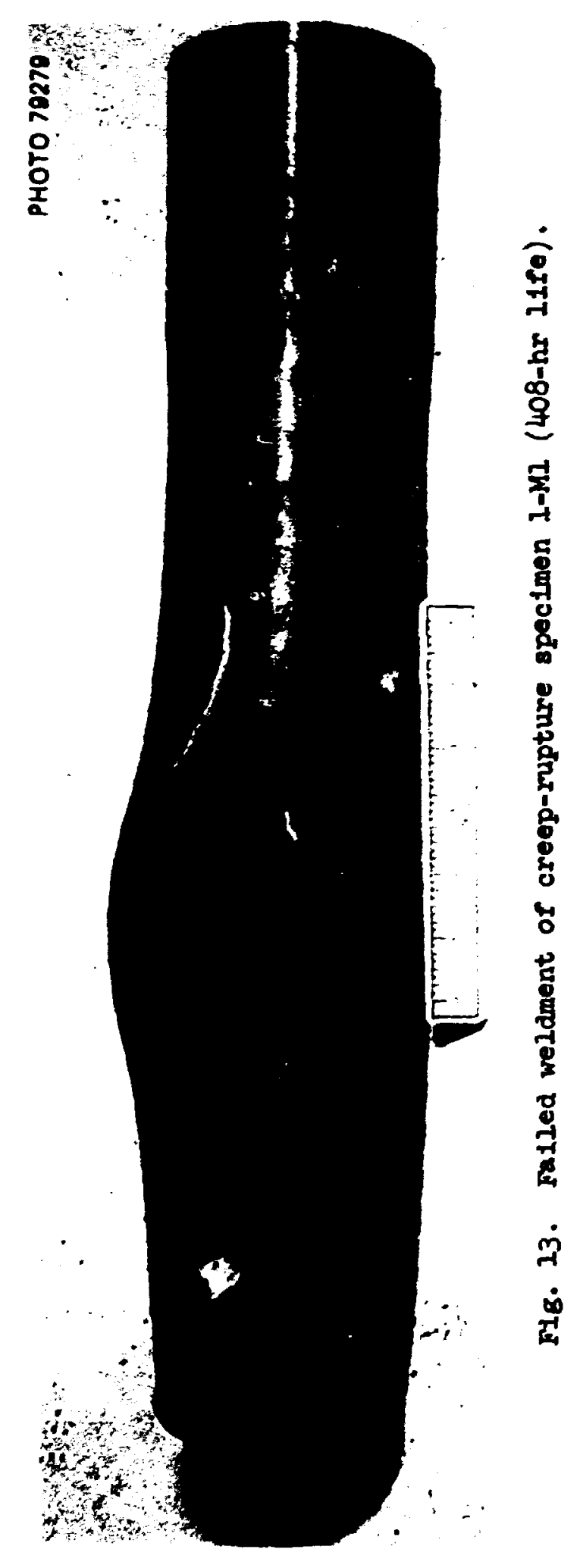




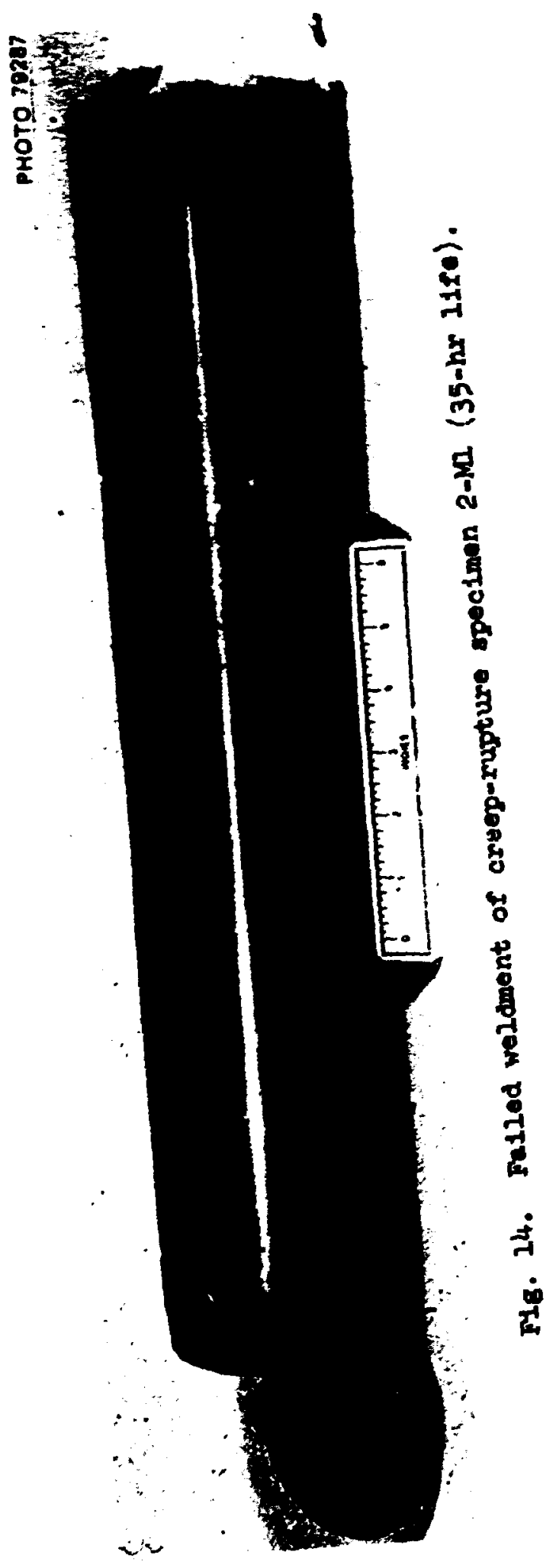




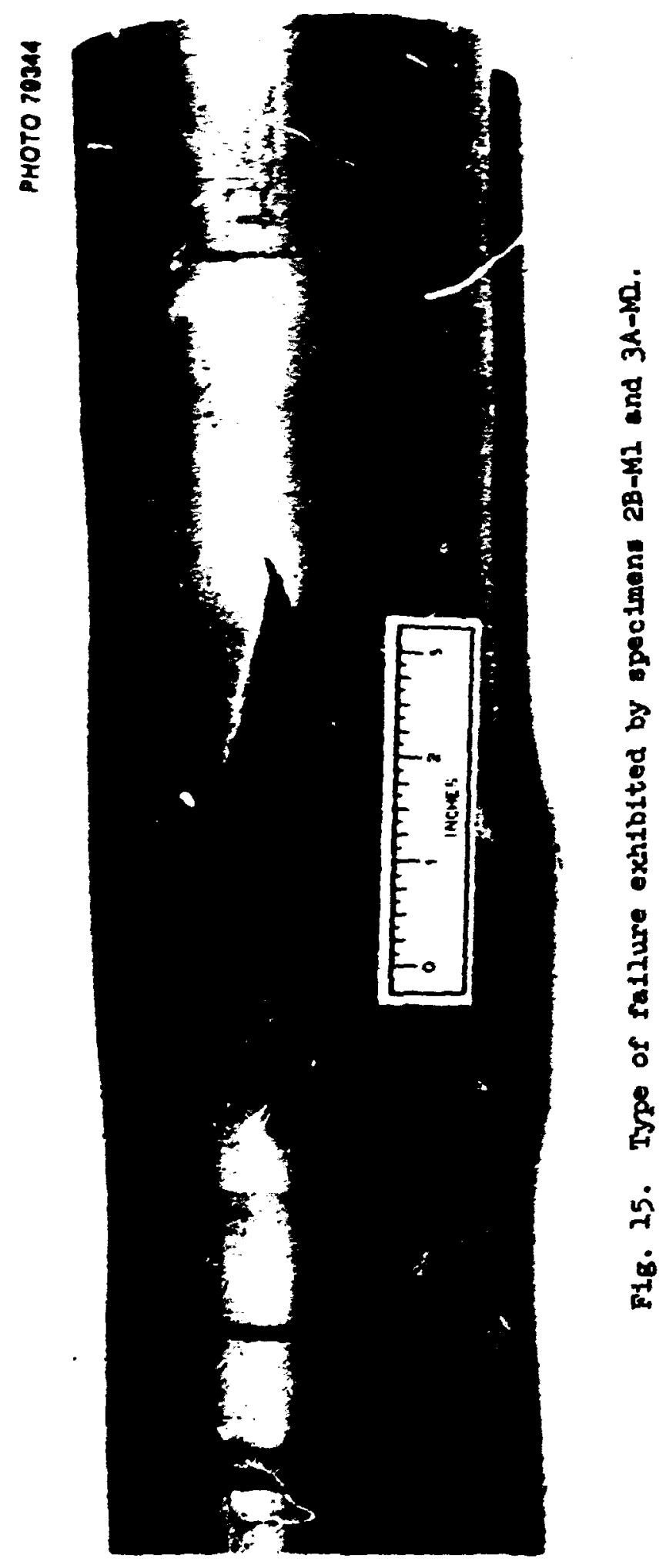




\subsubsection{Specinen $3+10$}

Syecinen 3-th was pressurized to $16.6 \mathrm{MPe}$ (2410 poif) and failed arter $43 \mathrm{hr}$ bs coplete separation of the head from the cylinder (as with specimen 2-Mi). On this specinen, cantact between the filler core and the specinen cap also my have occurred. The 43-hr sailure point, as wth the 35-hr ruilure point for specinen 2-Hn, was thus not recorded as valid creep-rupture data. Repair was ade by welding a flat circular disk to the end of the cylinder, and this specinen, specinen 3A-A1, fuiled after $153 \mathrm{br}$ by an adal crack in the cylinder. The total test time at failure was $196 \mathrm{hr}$.

\subsubsection{Specinen 1-1.2}

This specimen was tested at $14.1 \mathrm{MPn}$ (2040 psig) for $475 \mathrm{hr}$, at which tive pressure was lost due to develog nent of a pinhole leak in the headto-cylinder weld region. The specimen was repaired by removal of about $25.4 \mathrm{~m}$ ( $1 \mathrm{in.}$ ) of the end of the speciner and velding a flat circuiar disk to the end of the cylinder. The resuiting modified specimen, designated specinen $\mathrm{L}-\mathrm{H}$, was returned to test. The test was interrupted for dimensional inspections at total test times of 1000 and $2000 \mathrm{hr}$. Failure occurred at a total test time of $3576 \mathrm{hr}$ by an axial crack in the cylindrical portion of the specimen (see PIg. 16).

\subsubsection{Specimen 2-12}

This specimen, pressurized to $14.1 \mathrm{MPz}$ (2040 psig), was tested as planned with intermptions for dimensional inspectioss after total test times of 500, 1500, and $2000 \mathrm{hr}$. Pallure occurred at $3996 \mathrm{hr}$, when a series of gandl axial cracks developed in the cylinder similar to those shown ti Figs. 16 and 17.

\subsubsection{Specimen $3-1.2$}

This specimen, tested at a pressure of $14.1 \mathrm{MPa}$ (2040 psig), was interrupted for dimensional inspections at 500,1000,2000,4000, and 8000 hr total test time. The specimel falled at $972 \mathrm{hr}$ through a very fine pattern of cracks in the cylinder as shom in Fig. 17. 


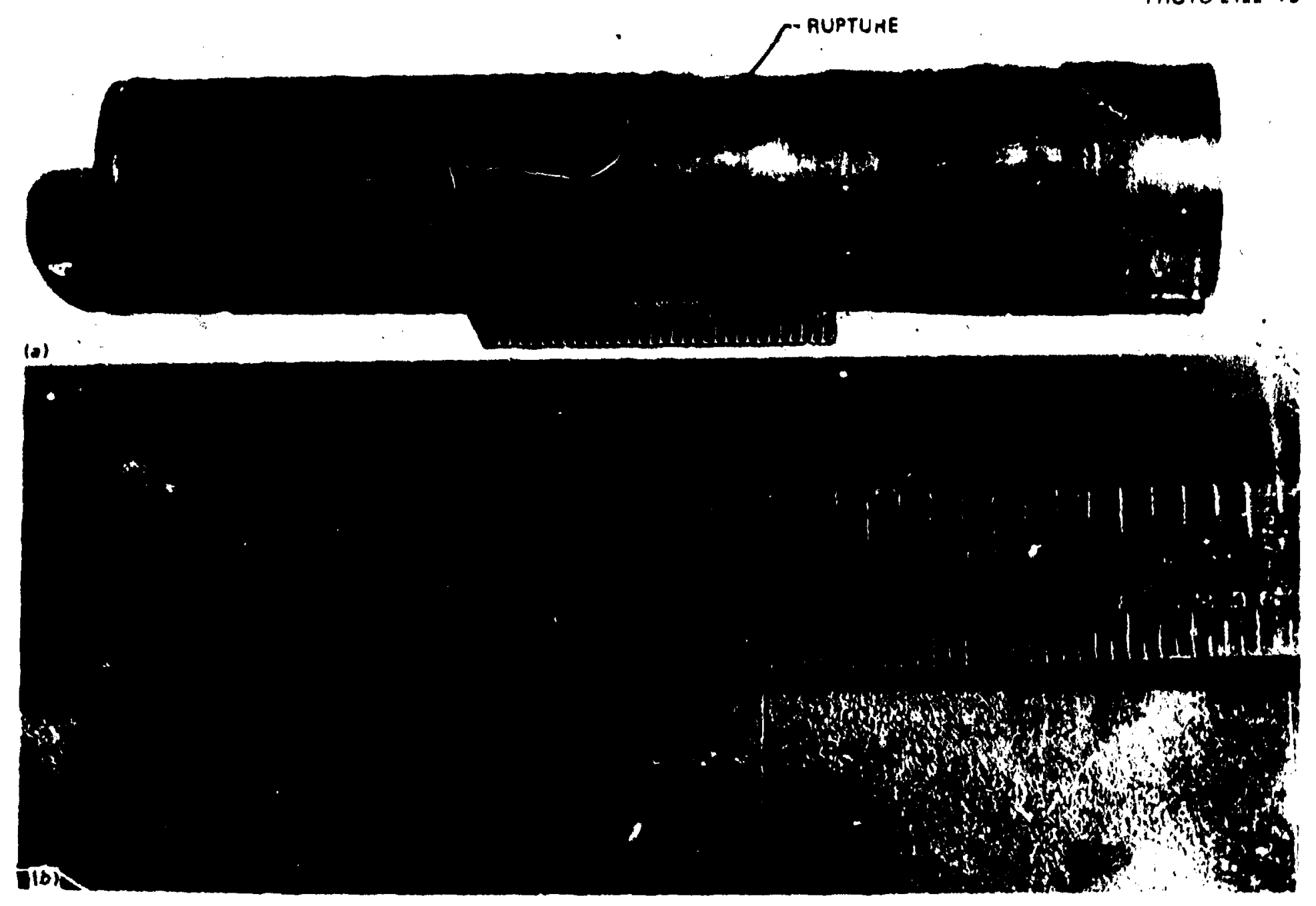

Fig. 16. Falled weldment of creep-rupture specimen 2A-N2. (a) Overall view; (b) closeun. 
32

P toro 1200-n

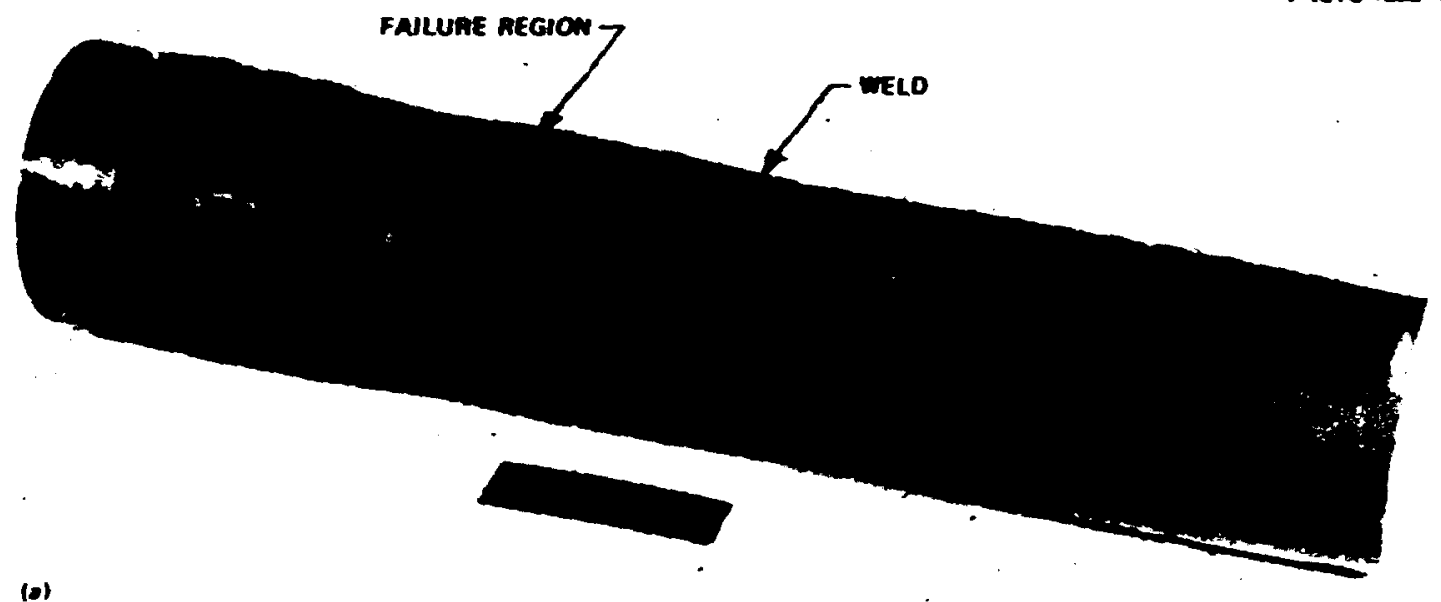

(b)

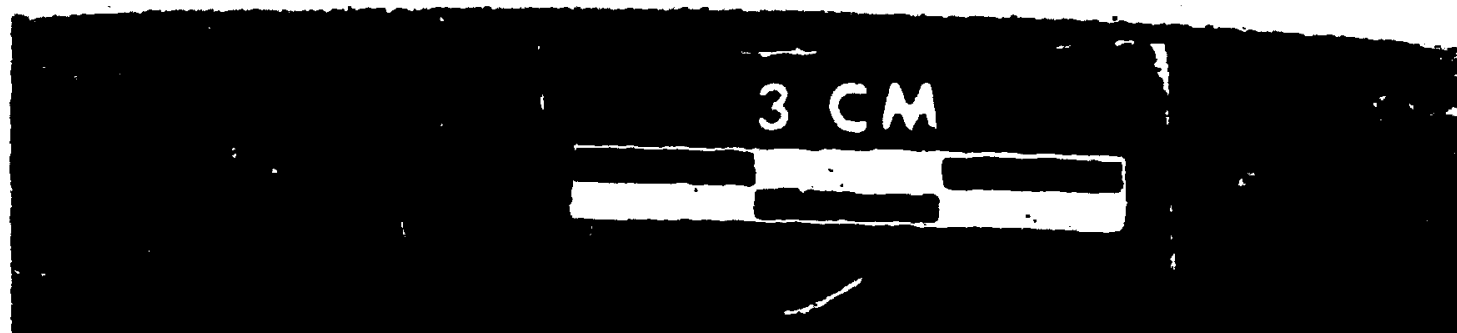

Fig. 17. Failed reldment of creep-rupture specimen 3-ke. (a) Overili view; (b) closeup showing pattern of snall cracks in failure region. 


\subsubsection{Specimen 4-12}

This specinen, like the first series of veidment specimens, was tested at $16.6 \mathrm{MPa}(2410 \mathrm{psig})$. The test was interrupted at 500 and 1000 $\mathrm{hr}$, and fallure occurred at $1136 \mathrm{hr}$. Horever, this is not considered a valid failure point since it occirred during a temperature excursion caused by a malfunction of the temperature controller. 


\section{DEFORATIOA DATA ARI ARALYSIS}

\subsection{Defarmation Data}

Heasurements of strains and/or defornations at these test temperatures present many difficulties. It was thus decided that acceptable deformation results courd be obtained by making comarative sets of dimensional measurements at roon temperature for discrete $t$ ines throughout the ilfe of a specimen. To provide a datum, the specimens vere scribed with circumferential lines on the cylinder and cap and with axial lines each $60^{\circ}$ around the circumference of the closure cap. The latter lines defined the ands of six radii formed by three planes passing through the longitudinal axis of the cylinder. These scribe lines are visible in Pig. 3.

The dimensional meesurements were made using a highly sophisticated machine that normally is used for making dimensional inspections of complex structural parts. This machine has a rotating index table and a sensitive surface probe with precise $x-y-z$ movemeni.

The specimen was mounted in an upright position (i.e., closure cap down on the indexing table with the longitudinal axis of the specimen in line with the geometric center of the table. The radial displacement of the probe was measured from the center of the table, and its heigh; was referenced to the top surface of the table. The table wes rotated to align the probe with one of the six scribe lines on the closure cap. Then the probe was moved vertically up the surface of the specimen and across the head with a measurement of helght and radial displacement being made at each circumferential scribe line. This procedure was repeated for each of the six scribe line positions (i.e., at $60^{\circ}$ intervals) around the circumference of the specimen closure cap. The resulting set of measurements of heights and radil were used in comparison to simflar dimensional measurements for the original undeformed specimen to compuis the displacement of speciflc points on the specimen surface. These displacements vr:re used to calcilate tine total inelastic strain, will be discussed in subsection 4.2 . 
One linitation on this procedure was that it was assued that the deformations would be essentially axisymetric. Ibis proved to be acceptable, although significant circuferential displacenent occurred in cases where the specinen fulled through a loog axial crack (see Fig. 12). This disflacenent, horever, was concentrated in the rupture region where the specinens vere distorted due to the failure. The distortion thus placed linits on the reliability of the computed strains in the rupture region.

\subsection{Analysis of Deformation Data}

The nethod used for converting the deformation data into strains was to identify material particles on the surface of the specinen by considering the specinen to be in a hypothetical reference state in which its gecuetry was a perfect cylinder, flat head, or hemisphere depending on the region or type of the specimen being considered. The surfuce strains were calculated based on the deviation of the actual surface, obtained from the dimensional measurements, from this hypothetical perfect surface.

For the cylindrical region of the specimen, a cylindrical coordinate system was then set up and each particle vas idantified by the reference coordinates $(\bar{\theta}, \bar{z})$. The deformed location of a parificle was given by its Cartesian coordinates $(x, y, z)$, and the undeformed iocation was given by the Cartesian coordinates $(\hat{x}, \hat{y}, \hat{z})$. To interpolate between measured points, the fcllowing series was used:

$$
\begin{aligned}
x(\bar{\theta}, \bar{z})=P_{1}(\bar{z})+P_{2}(\bar{z}) \cos \bar{\theta}+P_{3}(\bar{z}) \sin \bar{\theta}+P_{4}(\bar{z}) \cos 2 \bar{\theta} \\
\\
+P_{5}(\bar{z}) \sin 2 \bar{\theta}+P_{6}(\bar{z}) \cos 3 \bar{\theta},
\end{aligned}
$$

where $P_{1}, \ldots, P_{6}$ are polynomiai splire functions. The spline runctions are continuous and have two continuous derivatives across the scribe rings. Interpolation equations of the same form were used for $y, z, \hat{x}$, $\hat{\mathbf{y}}, \hat{\mathbf{z}}$.

For a hemispherical cap the reference state was a perfect hemiophere, and the interpolation equation was 


$$
\begin{aligned}
& x(\bar{\theta}, \bar{\emptyset})=P_{1}(\cos \bar{P})+\sin \bar{Z} P_{2}(\cos \bar{q}) \cos \bar{\theta} \\
& +\sin \bar{\theta} P_{3}(\cos \bar{X}) \sin \bar{\theta}+\sin ^{2} \bar{y} P_{4}(\cos \bar{\gamma}) \cos 2 \bar{\theta} \\
& +\sin ^{2} \bar{y} P_{5}(\cos \bar{y}) \sin 2 \bar{\theta}+\sin ^{3} \bar{g} P_{6}(\cos \bar{x}) \cos 3 \bar{\theta},
\end{aligned}
$$

where $\bar{x}$ is the reference angle neasured rrom the pole.

Por a fint head, the reference state was a nat disk, and the interpolation runction wes

$$
\begin{aligned}
x(\bar{r}, \bar{\theta})= & P_{i}\left(\vec{r}^{2}\right)+\bar{r} P_{2}\left(\vec{r}^{2}\right) \cos \bar{\theta}+\bar{r} P_{9}\left(\vec{r}^{2}\right) \sin \bar{\theta} \\
& +\vec{r}^{2} P_{4}\left(\vec{Z}^{2}\right) \cos 2 \bar{\theta}+\bar{r}^{2} P_{5}\left(\vec{r}^{2}\right) \sin 2 \bar{\theta}+\overline{r^{3}} P_{6}\left(\vec{r}^{2}\right) \cos 3 \overline{0}
\end{aligned}
$$

The form of the head equations was chosen so as to force the feformition to be analytic at the center point.

Using index notation, the strain tensor is defined as

$$
e_{m n}=\frac{l}{2}\left(\frac{x_{i}}{d \bar{x}_{m}} \frac{d x_{i}}{d \bar{x}_{n}}-\frac{\partial \hat{x}_{j}}{\partial \bar{x}_{m}} \frac{j \dot{x}_{j}}{\overline{\alpha \bar{x}_{n}}}\right),
$$

where:

$$
\begin{aligned}
& x_{1}=z, \bar{x}_{2}-y, \bar{x}_{3}-\hat{z}, \\
& \hat{x}_{1}=\bar{x}, \hat{x}_{2}=\hat{y}, \dot{x}_{3}=\hat{z}, \\
& \bar{x}_{1}=\bar{r}, \bar{x}_{2}=\bar{\epsilon}, \bar{x}_{3}=\bar{z} \text { for a cylinder or Nat head, } \\
& \bar{x}_{1}=\bar{r}, \bar{x}_{2}=\overline{\hat{\theta}}, \bar{x}_{3}=\bar{l} \text { for a hemisphere. }
\end{aligned}
$$

Because it follows the conventions of tensor analysis wich empasize sioplicity of transformation, the strain tensor $e_{m n}$ does not reduce to engineering strain in the infinitesimal limit. The alternative strain measure

$$
\begin{aligned}
& e_{m n}=\frac{1}{2}\left(\frac{\partial x_{1}}{\partial \bar{x}_{m}} \frac{\partial x_{1}}{d \bar{x}_{n}}-\frac{\partial \dot{x}_{j}}{\partial \bar{x}_{m}} \frac{\partial \dot{x}_{1}}{\partial \bar{x}_{n}}\right) / \sqrt{\frac{\partial \hat{x}_{k}}{\partial \bar{x}_{m}} \frac{\partial \dot{x}_{k}}{\partial \bar{x}_{m}} \frac{d \dot{x}_{l}}{d \bar{x}_{n}} \frac{d \dot{x}_{l}}{d \bar{x}_{n}}}, \\
& \text { (no sumation on } m, n \text { ) }
\end{aligned}
$$


sametimes referred to as the "physical components" of the tensor, is not itself a tensor but does reduce to engineering strain (except for a factor of 2 in shear) and is therefore easier to interpret.

The above discussion is descriptive of the displacement field for the exterral surface of the specimen. Assuming that the thin-shell geometry relations are valid, it is also possible to calculate the strain field on the inner surface of the specimen. To accouplish this, the following shell analys:s was incorporated into the computer program uced for date reduction.

Let $\hat{\boldsymbol{x}}_{\mathbf{i}}\left(\alpha_{1}, \alpha_{2}\right), 1=1,2,3$, denote the global Cartesian coordinates of the measured location of a point on the outer surface of the specimen before deformation and let $x_{1}\left(\alpha_{1}, \alpha_{2}\right)$ be the corresponding coordinates after deformation, where $\alpha_{1}, \alpha_{2}$ are the local reference coordinates on the outer surface:

\begin{tabular}{lll} 
& $\alpha_{1}$ & $\alpha_{2}$ \\
\cline { 2 - 2 } & $\bar{\theta}$ & $\overline{\mathbf{z}}$ \\
Fylinder & $\overline{\mathrm{r}}$ & $\bar{\theta}$ \\
Hemispherical head & $\bar{\phi}$ & $\bar{\theta}$
\end{tabular}

All the barred coordinates rexer to an ideal reference state of the specimen.

A vector nomal to the outer surface after deformation is given by the Cartesian coordinate components:

$$
\begin{aligned}
& u_{1}=\frac{\partial x_{2}}{\partial \alpha_{1}} \frac{\partial x_{3}}{\partial \alpha_{2}}-\frac{\partial x_{2}}{\partial \alpha_{2}} \frac{\partial x_{3}}{\partial \alpha_{1}}, \\
& u_{2}=\frac{\partial x_{3}}{\partial \alpha_{1}} \frac{\partial x_{1}}{\partial \alpha_{2}}-\frac{\partial x_{3}}{\partial \alpha_{2}} \frac{\partial x_{1}}{\partial \alpha_{1}}, \\
& u_{3}=\frac{\partial x_{1}}{\partial \alpha_{1}} \frac{\partial x_{2}}{\partial x_{2}}-\frac{\partial x_{1}}{\partial x_{2}} \frac{\partial x_{2}}{\partial \alpha_{2}},
\end{aligned}
$$

and similerly for the normal vector before deformation. The companents of a normal vector of unit length are given by 


$$
v_{1}=u_{1} / \sqrt{u_{1}^{2}+u_{2}^{2}+u_{s}^{2}},
$$

etc. Then, assuming that a line segment initially normal to the outer surface, and embedded in the material, remains straight and normal after deformation and neglecting changes in wall thickness due to deformation, that is, the Kirchhoff-Love hypothesis of thin-shell theory, the inside surface strain tensor if given (using the sumation and range corventions) by

$$
\begin{aligned}
\mathbf{e}_{\mathbf{m}}=\frac{1}{2} & {\left[\left(\frac{\partial x_{i}}{\partial \alpha_{m}}-h \frac{\partial v_{i}}{\partial \alpha_{m}}\right)\left(\frac{\partial x_{i}}{\partial \alpha_{n}}-h \frac{\partial v_{i}}{\partial \alpha_{n}}\right)\right.} \\
& \left.-\left(\frac{\partial \hat{x}_{i}}{\partial \alpha_{m}}-h \frac{\partial \hat{v}_{i}}{\partial \alpha_{n}}\right)\left(\frac{\partial \hat{x}_{i}}{\partial \alpha_{n}}-h \frac{\partial \hat{v}_{i}}{\partial \alpha_{n}}\right)\right],
\end{aligned}
$$

where $h$ is the constant wall thickness.

The physical components of the inr surface strain can then be calculated in the same way as for the outer surface. The approximations above greatly simplify the numerical calculations. They are consistent with a large-deflection, small-strain, thin-shell approximation for bending. The outside surface streins, however, are valid for large deflection and large strain since they are based on the measured deformation of the specimen. Results fram these calculations are discussec in the next section. 


\section{TRST RBSULHS AID COACLUSIORS}

\subsection{Deformation Behavior of Specimens}

Calculation of strains for the first series of specimens was made mare difficult by the anount of distartion the material underwent at failure. In particular, the flat heads of specimens 2-AI and 3-kI were badly varped during rupture. In the regions arry from the failure ares and in the second series of specimens, where failure generally occurred by sinall cracks, the calculated strains were much more consistent.

In order to wake comparisons of the general behavior of weldments and base metal, two approaches were used. First, selected points on the outer surface of the cylindrical part of the epecimens were observed with respect to their time-dependent bahavior. Points were chosen in all base metal reglons, membrane stress only, and at the center of the deposited welds. The strains at these selected points, calculated from ae deformation measurements, indicate the general time-dependent behavior of the weld and base metals.

Results for the first series of specimens are summarized in Table 4. The rupture strains, whic' are outside surface strains, were taken at polints away from the actual fallure area and should be indicative of the circumferential strain just prior to fallure. Comparable results for the second series of specimens are show in Table 5 and Fig. 18 . In both cases, the strains reported are the total inelastic outside surface strain and therefore include the loading strains.

The deformation response or the second series of specimens, Fig. 18, indicates reasonably consistent comparative creep behavior between the specimens tested. lio trend curves are included over the time range 0 to $500 \mathrm{hr}$ since both plastic loading strain and creep occurred in an undePlned (for these tests) ay. As may be seen in Tables 4 and 5 and Fig. 18, the pipe material exhibited greater total inelastic strain than the bar material. This is consistent with product-form characterization results, 8 wich show the pipe material to have a lover initial yield poiat and slightly higher minimum creep rates than the bar material for stress levels comparable to these veldment specimens. This creep rate behavior is shown in Fig. 19. 
Table 4. Comparison of weld-base naterial behavior in the cylinder region of WCR-1 specimens

Teuperature

Internal pressure

Axial stress

Circuferential stress

Bffective stress (ron Mises) $593^{\circ} \mathrm{C}\left(1100^{\circ} \mathrm{F}\right)$

$1.66 \mathrm{MPa}$ (2410 psi)

$90.9 \mathrm{MPa}(13,180 \mathrm{psi})$

$181.8 \mathrm{MPa}(26,370 \mathrm{psi})$

\begin{tabular}{|c|c|c|c|c|c|}
\hline \multirow{2}{*}{$\begin{array}{l}\text { Specimen } \\
\text { No. }\end{array}$} & \multirow{2}{*}{$\begin{array}{l}\text { Test } \\
\text { time } \\
\text { (hr) }\end{array}$} & \multicolumn{3}{|c|}{$\begin{array}{l}\text { Total inelastic cir- } \\
\text { cunferential strain }\end{array}$} & \multirow{2}{*}{$\begin{array}{l}\text { Conments on } \\
\text { failure mode }\end{array}$} \\
\hline & & $\underset{\text { stock }}{\text { Bar }}$ & $\begin{array}{l}\text { Pipe } \\
\text { stock }\end{array}$ & $\begin{array}{c}\text { At, } \\
\text { weld }\end{array}$ & \\
\hline $1-\mathbf{1}$ & 408 & & $10.0^{c}$ & & Axial crack in cylinder \\
\hline $2-x$ & 35 & 2.1 & 2.8 & 0.6 & $\begin{array}{l}\text { Circumferential crack be- } \\
\text { tween head and cylinder; } \\
\text { upper half (head end) of } \\
\text { specimen replaced }\end{array}$ \\
\hline $2 A-M I$ & 123 & FA & RA & INA & $\begin{array}{l}\text { Circumferential crack be- } \\
\text { tween head and cylinder; } \\
\text { flat head repaired by } \\
\text { welding }\end{array}$ \\
\hline $2 B-2 B$ & 304 & $\mathrm{RA}^{\mathrm{C}}$ & 6.4 & 2.9 & $\begin{array}{l}\text { Axial crack in cylinder; } \\
\text { failed section tested } \\
269 \mathrm{hr}\end{array}$ \\
\hline $3-\mathrm{Mn}$ & 43 & MA & NA & $\mathbf{M A}$ & $\begin{array}{l}\text { Circumferential crack be- } \\
\text { tween head and cylinder; } \\
\text { flat head repaired by } \\
\text { weloing }\end{array}$ \\
\hline $3 A+12$ & 200 & 4.1 & $6.9^{c}$ & 1.5 & Axial crack in cylinder \\
\hline
\end{tabular}

The deformation of the base metal was much greater than thet of the comparably located weldments. During the first $2000 \mathrm{hr}$ of testing of the second series of specimens, no clearly defined deformation behavior of the weldments was established. The fact that decreases in previously measured strain levels or negative strains are shown for the weldments may be at- 
rable 5. Camparison of weld-base metel materiel behavior in cylinder regton of WCR-2 specimens

\begin{tabular}{|c|c|c|c|c|c|c|c|c|c|c|}
\hline \multirow{3}{*}{$\begin{array}{l}\text { Specimen } \\
\text { No. }\end{array}$} & \multirow{3}{*}{ Materlal } & \multirow{2}{*}{\multicolumn{2}{|c|}{ Stress $8^{a}$}} & \multicolumn{7}{|c|}{ Total teat time (hr) } \\
\hline & & & & \multirow[t]{2}{*}{500} & 1000 & 1500 & 2000 & 4000 & \multirow{2}{*}{$\frac{8000}{\ln }$} & \multirow[t]{2}{*}{9712} \\
\hline & & MPa & $\mathbf{k s 1}$ & & \multicolumn{4}{|c|}{$\begin{array}{c}\text { Average circumferential etrain } \\
(\%)\end{array}$} & & \\
\hline $1-M 2$ & Base metal (plpe) & 117.2 & 17.0 & $1.69^{b}$ & & & & & & \\
\hline IA-ME & Base metal (pipe) & 117.2 & 17.0 & & 1.99 & & 2.47 & $3.67^{c}$ & & \\
\hline $2-1 / 2$ & $\begin{array}{l}\text { Base metal (plpe) } \\
\text { Base metal (bar) } \\
\text { Weld }\end{array}$ & $\begin{array}{l}117.2 \\
117.2 \\
117.2\end{array}$ & $\begin{array}{l}17.0 \\
17.0 \\
17.0\end{array}$ & $\begin{array}{l}1.48 \\
1.04 \\
0.21\end{array}$ & & $\begin{array}{l}2.01 \\
1.52 \\
0.17\end{array}$ & $\begin{array}{l}2.40 \\
1.67 \\
0.30\end{array}$ & $\begin{array}{l}7.05^{4} \\
1.79 \\
0.29\end{array}$ & & \\
\hline $3-M 2$ & $\begin{array}{l}\text { Base metal (pipe) } \\
\text { Base metal (bar) } \\
\text { Weld }\end{array}$ & $\begin{array}{l}117.2 \\
117.2 \\
117.2\end{array}$ & $\begin{array}{l}17.0 \\
17.0 \\
17.0\end{array}$ & $\begin{array}{r}1.57 \\
0.98 \\
-0.23\end{array}$ & $\begin{array}{l}2.20 \\
1.74 \\
0.27\end{array}$ & & $\begin{array}{l}2.57 \\
1.87 \\
-0.01\end{array}$ & $\begin{array}{l}3.35 \\
2.44 \\
0.24\end{array}$ & $\begin{array}{l}4.32 \\
3.01 \\
0.37\end{array}$ & $\begin{array}{l}5.21^{\mathrm{e}} \\
3.03 \\
0.41\end{array}$ \\
\hline $4-1 / 2$ & $\begin{array}{l}\text { Base metal (plpe) } \\
\text { Base metal (bar) } \\
\text { Weld } \\
\text { Weld }\end{array}$ & $\begin{array}{l}136.5 \\
136.5 \\
136.5 \\
236.5\end{array}$ & $\begin{array}{l}19.8 \\
19.8 \\
19.8 \\
19.8\end{array}$ & $\begin{array}{l}1.94 \\
1.73 \\
0.29 \\
0.32\end{array}$ & $\begin{array}{l}2.56 \\
1.91 \\
0.27 \\
0.23\end{array}$ & $\begin{array}{l}7.98^{1} \\
6.30^{f} \\
2.30 \\
2.46\end{array}$ & & & & \\
\hline
\end{tabular}

Elastlcally calculated von Mises stress.

Taken at $475 \mathrm{hr}$.

cpallure strain at $3576 \mathrm{hr}$.

Dailure strain at $3996 \mathrm{hr}$.

Failure strain at $972 \mathrm{hr}$.

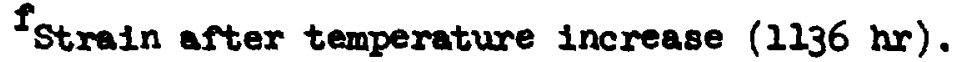


ORNL DWG $77 \quad 7237$

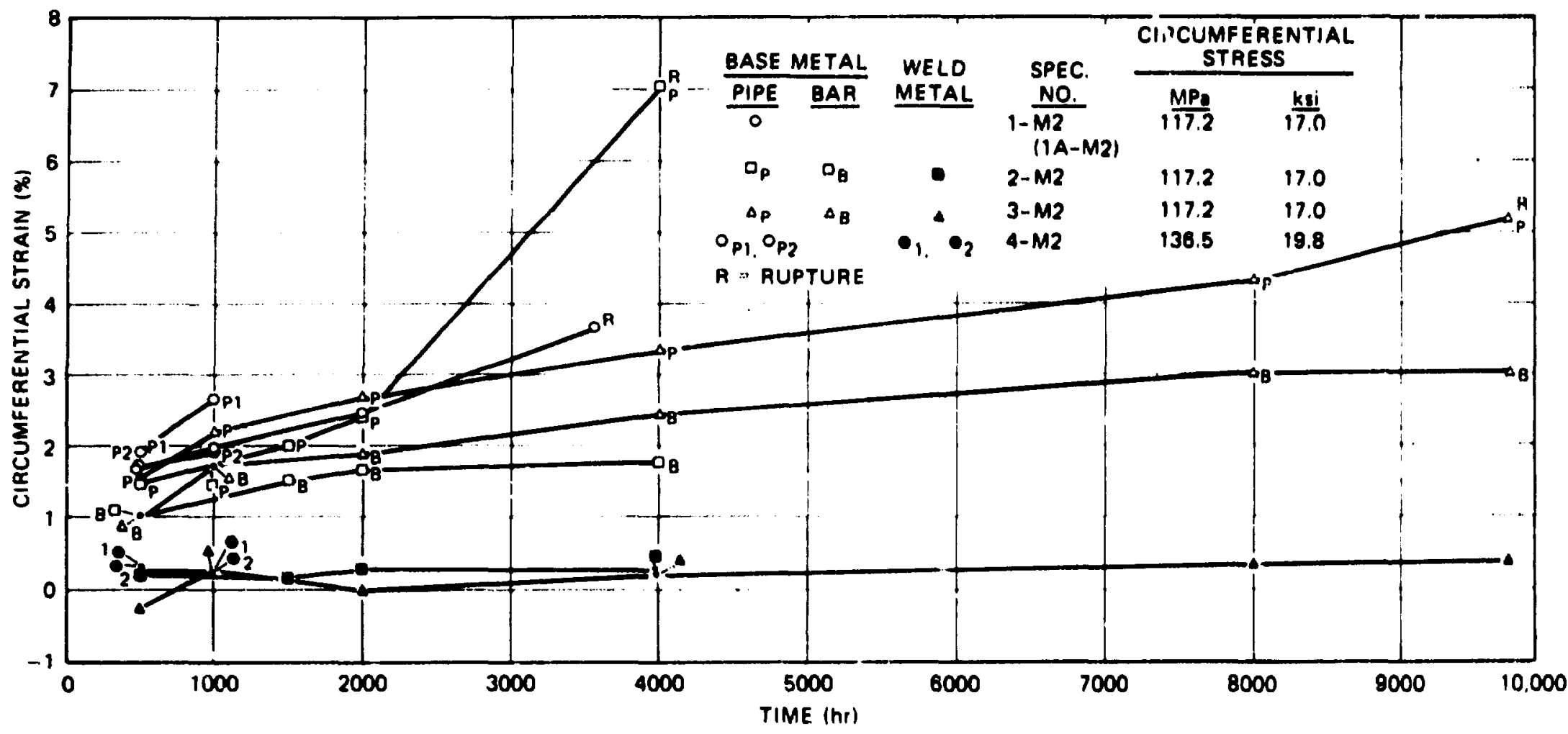

Fig. 18. Comparative deformation behevior of wold and base meti is in weldment creep-rupture series 2 specimens. 


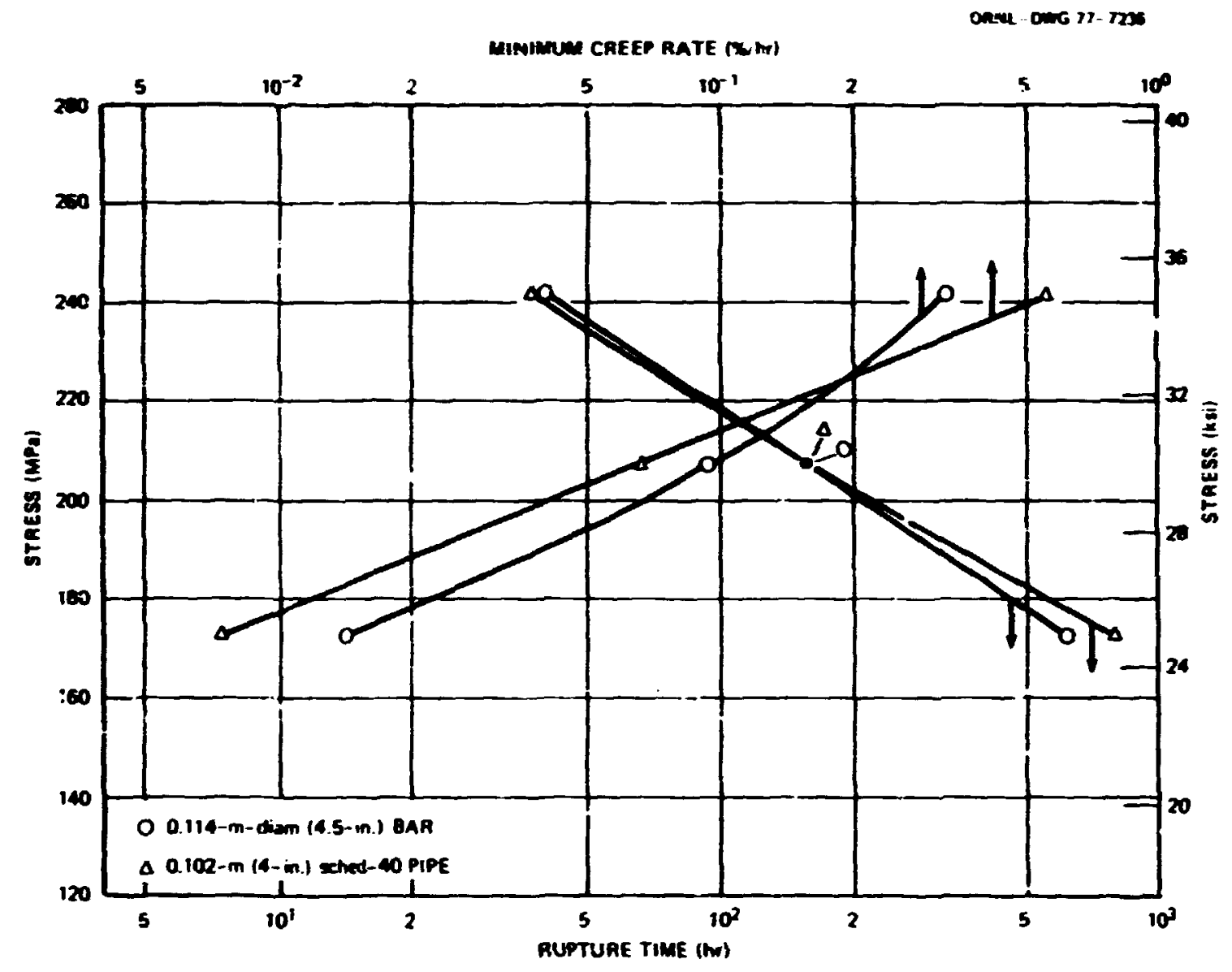

Fig. 19. Minimum creep rate and time to rupture for 0.114 -m-diam (4 1/2-1n.) bar and 0.102-m (4-in.) sched-40 pipe of type 304 stainless steel (reference heat 972796 ).

tributed to several sources. The accuracy with wich the deformation measurements were made woulc definitely be a contributing factor. For very smail deformations, as in the weld area, small absolute errors in measurements could produce scatter in the final calculated strains. The poisibility also exists that relaxation of the residual stresses in the weldment could lead to a decrease in specimen diameter at the weld location. snother likely candidate for producing decreases in strain is the precipitation of carbides from the highly stressed weldment at elevated temperature. ${ }^{10}$ This precipitation with its associated volume decrease could account in part for the weldment deformation behavior observed.

Although the weldments in the membrane regions of the cylindere did not undergo uuch strain, these weldments were capable of sustaining large 
deformations with no loss of integrity. Welds in the cylincer-to-head junction regions and in the heads of tne specimens were subjected to large bending strains as is shom in Fig. 20 . Failure of this specimen (failure is discussed in the next subsection) was in the base metal in the cylinder-to-head junction region.

The inside and outsice surface strains for a number of different cases were calculated using the approach discussed in subsection 4.2 . These results are contained in the appendix to this raport.

\subsection{Pai ure Behavior of Specimens}

Pailure of these specimens as well as the overall deformation behavior was of interest. The rupture lives of these specimens is shown in Fig. 21. The data are only for failures in the membrane regions of the cylinders for which the biaxial stress ratio was 2:1. Failures that occurred in the head-to-cylinder junction regions of the specimens are not shown die to the complexity of the stress fie:t at these discontinuities. Two sets of symbols are used in Fig. 21, one representing data correlated on the basis of von Mises effective stress and one representing data correlated on the basis of maximu principal stress. The maximum principal stress gave better agreement with the uniaxial trend line over the full range of test conditions.

All the specinen failures originated in the base metal. In the headto-cylinder junction region, the weldment was much stronger than a geometrically comparable all-base-metal junction region. This is exhibited rather graphically in Fig. 22, which is a cross-sectional micrograph showing the cylinder wall, weldment, and head of specimen 1-Ml. This specimen failed by rupture of the cylinder after $408 \mathrm{hr}$ (see Fig. 13). For some period of this time the weld was cracked as show in Fig. 22, yet continued to function as a pressure boundary. In specimens 2-MI, $2 A-M I$, and 3-Mn, failure ocsurred in this region, which was all-base metal, whin 35 to $88 \mathrm{hr}$, respectively (see Fig. 14, typical).

Figure 23 shows the head-to-cylinder function region of specimen 1-M2, which failed after $475 \mathrm{hr}$. A crack developed in the base metal and propagated into the weld. As can be seen, the weld underwent a significant 


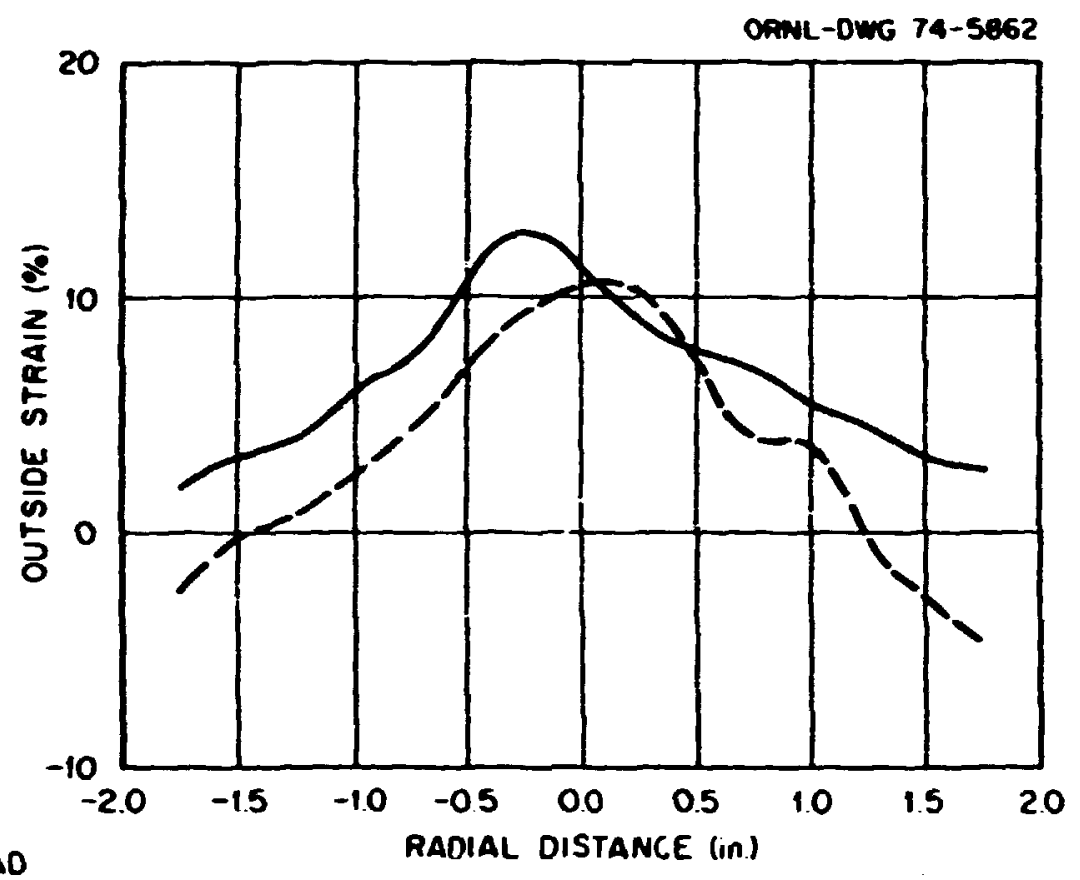

WCR SPEC. : 3-MI: HEAO

TEST TMME: $43 \mathrm{hr}$

REFERENCE DIAM. $120-300^{\circ}$

\section{LEGEND}

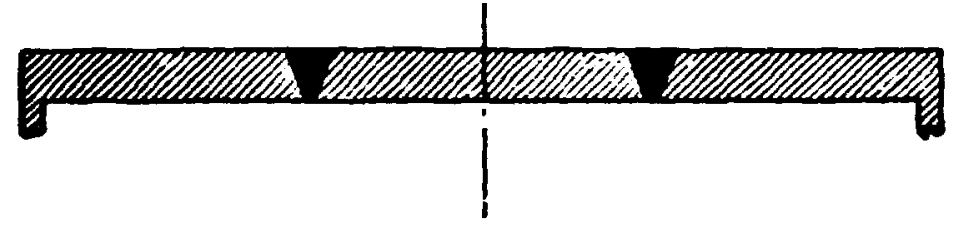

\section{RAOIAL STRAIN}

CIRCUMFERENTIAL STRAIN

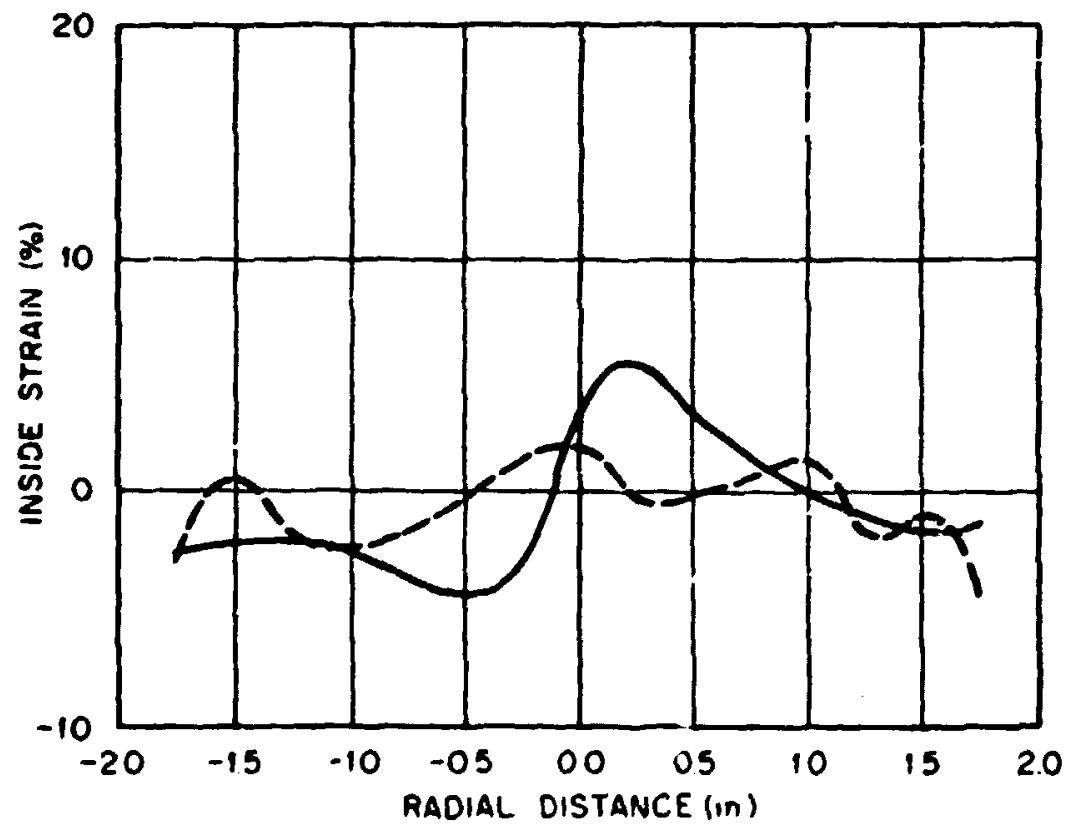

Fig. 20. Strain distribution in head of WCR specimen 3-Mn indicating strain capability of weldment. 


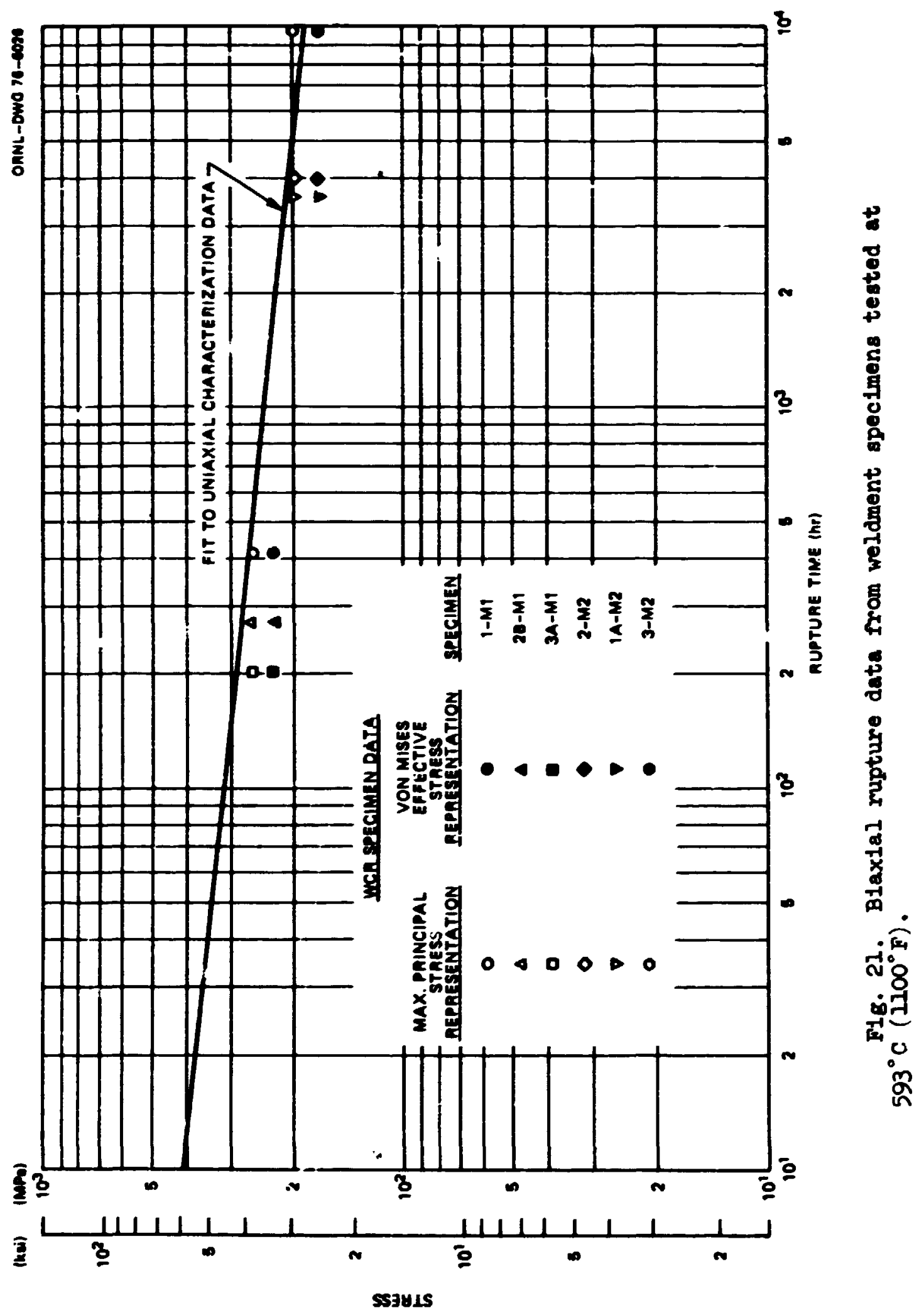




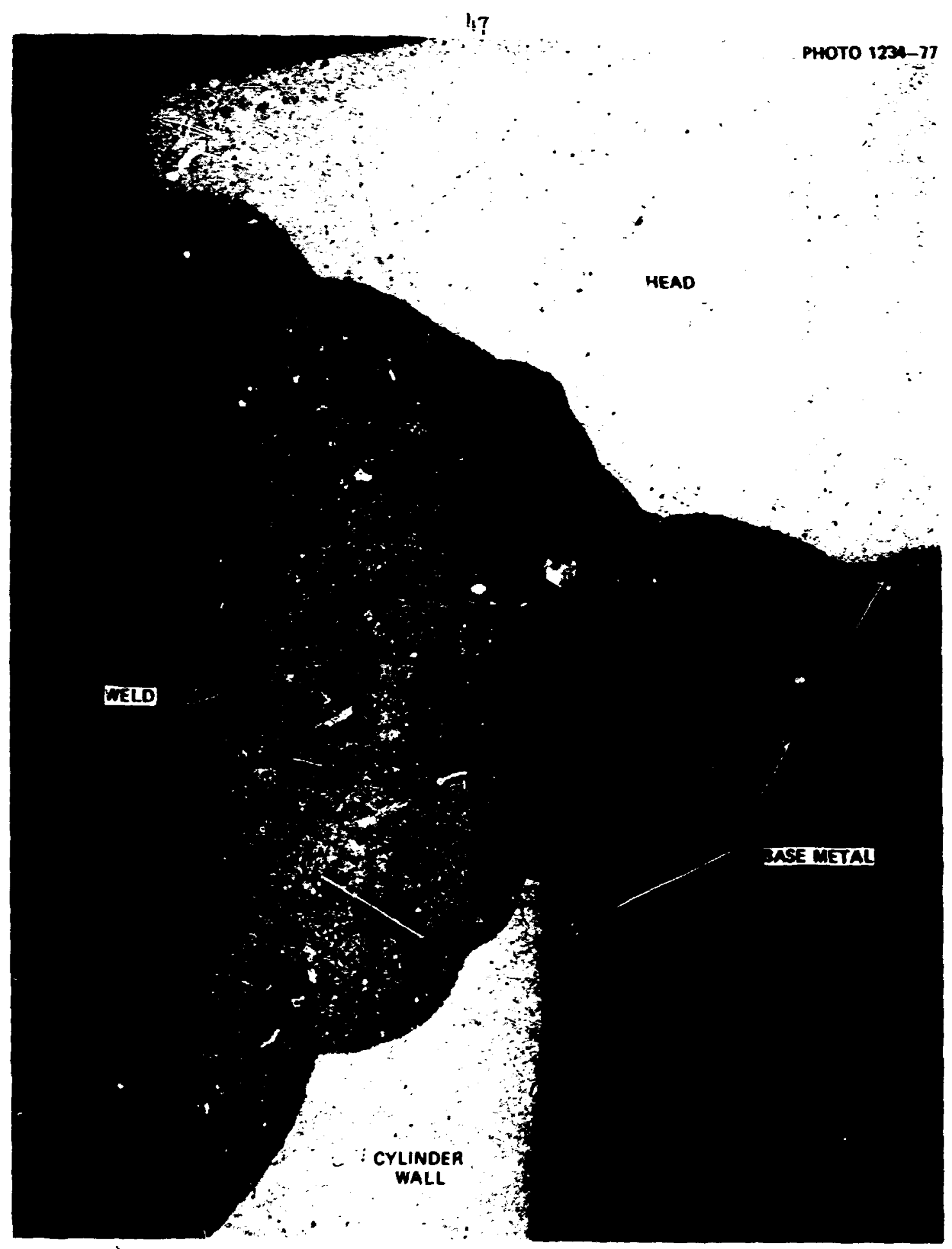

F1g. 22. Cross section of head-to-cylinder junction region in specimen 1-M after $408 \mathrm{hr}$ at $593^{\circ} \mathrm{C}\left(2100^{\circ} \mathrm{F}\right)$. 


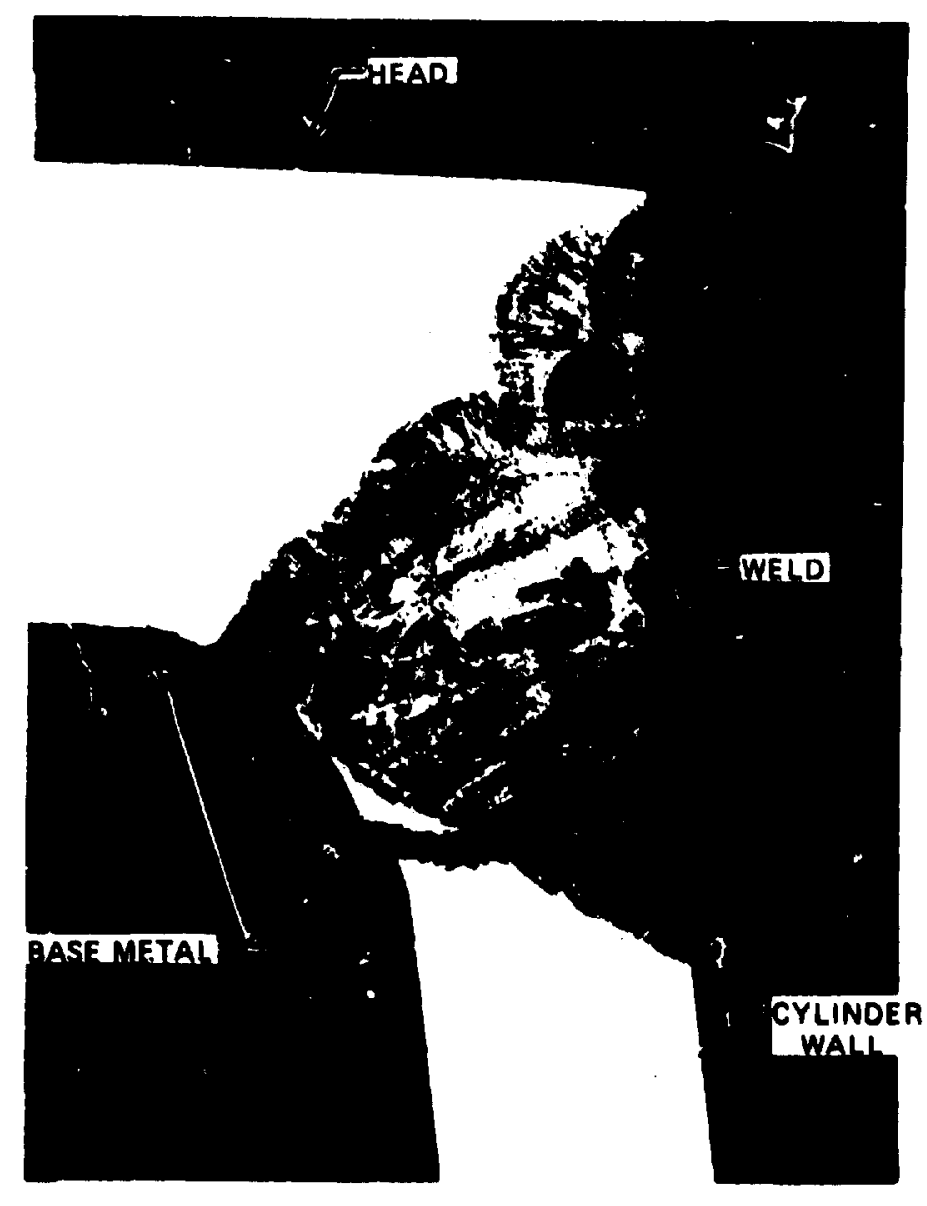

(a)

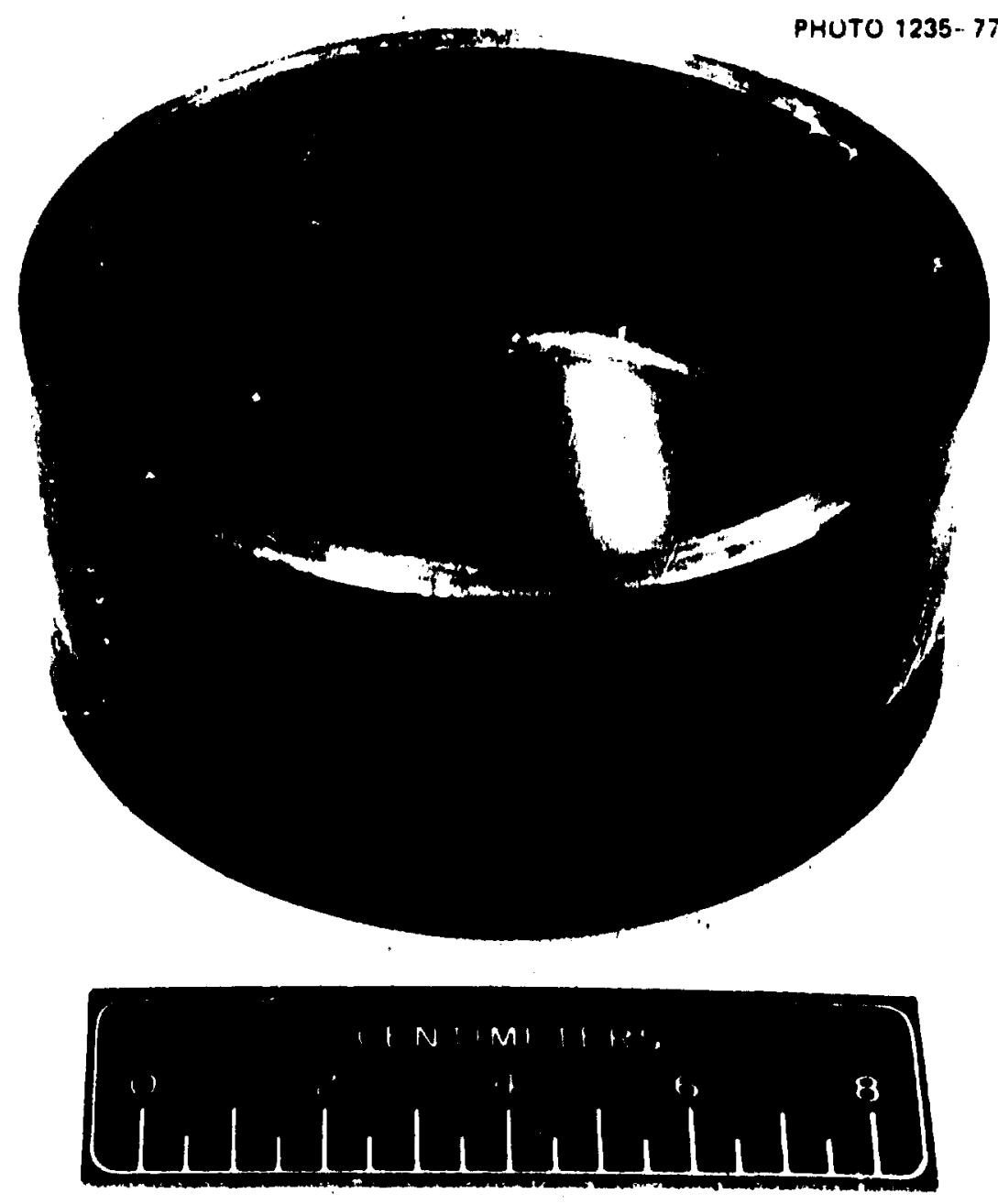

(b)

F1g. 23. Head-to-cylinder junction region in apecimen 1-M2 after $475 \mathrm{hr}$ at $593^{\circ} \mathrm{C}\left(1100^{\circ} \mathrm{F}\right)$. (a) Cross section of weldment; (b) vlew howing developed crack in junction region. 
ancunt of deformation before pressure loss througin a pinhole leak. In both specimens 1-10 and 1-1k2, the cracks extended a comolete $360^{\circ}$ around the inside of the junction region.

\subsection{Concliesions and Summary}

The number of tests conducted was not sufficient to yield what ore would consider to be a so'nd statistical sample so far as rupture behavior is concerned. Howerer, the information obtained is valiable in an assessment of the structural response of weldments subjected to both short- and long-term sterdy-state creep.

In assessing the resilts of these tests, several points are important with respect $; 0$ the comparative behavior of the base metal and weldments.

1. Tre rupture life of the specimen was letermined by the tase metal and not by the weldments.

2. The weldments were capable of undergoing large strains without apparent damage through cracking or tearing.

3. The weliments possessed superior resistance to craci growth as compared to the base metal.

4. For the test conditions, the maximum principal stress gave a better correlation between the uniaxial and biaxial failure data. 
Rerisances

1. R. G. Gilliland, The Banavior of Welded Joints in Stainless and AlIor Steels at Elevated Teperatures, Oiv-4781 (August 1972).

2. Interpretations of the ASig Boiler and Pressure Vessel Code, "Case 1592-7, Class 1 Co ponents in Bleveted Teperature Service," Amican Society of Mechnnical Engineers, Wev York, Dec. 22, 1975.

3. J. M. Corv, "Structural Testing," High-Te-pereture Structural Desige Methods for UPBR Co ponents Guarterly Propess Report for Period Bnding Septe-ber 30, 1972, OFul-ili-4058, p. 75 .

4. W. J. Anderson, D. F. Atkins, and J. H. Shively, Mechnical Properties of Stainless Steels in Sodiu, and Application to LraR Desige, AIAEC-13000 (Peb. 25, 1972).

5. R. W. Sulindean and R. D. Waddell, "Characterization of the ORth Reference Heat (Wo. Yr2796) of Type 304 Stairiess Steel," High-Terpereture Structural Desion Hethods for DIPBR Corponents guerterly Prozress Report for Period Ending Septenber 30, 1972 , ORal-TH-4058, p. 137 .

6. H. E. HcCoy, "Characterization of Product For," High-Tepereture Structural Desizn Yethods for MPBR Comonents guarterly Progress Report for Period Ending June 30, 2973 , ONI - L1-4356, p. 3 .

7. H. L. Greenstreet, J. M. Corun, and C. B. Pugh, Inrormal Progress Reports on Structural Design Hethods for IHPBR Couponents for October and Hovember 1970, Internal Menorandun, Oak Ridge Rational Laboratory (Dec. 1, 1970).

8. P. L. Yaggee, J. W. Styles, and S. B. Brak, Seniautomatic Apparatus for Creep and Stress-Rupture Tests of Thin-Wall Fuel-Cladding Tubes Under Internal Gas-Pressure ioading, ANL-7801 (September 1971).

9. H. E. NicCoy, "Characterization of Reference Heat Froduct Forms," High-Temperature Structural Design Hetbods for IMFBR Corponents Progress Report for Period Ending December 31, 1973, ORdi-4947, p. 1.

10. G. R. Brophy and D. E. Furman, "The Cyclic Temperature Acceleration of Strain in hieat Pesisting Alloys," Trans. ASM 30, 1115-38 (1942). 
51

APPENDDX 

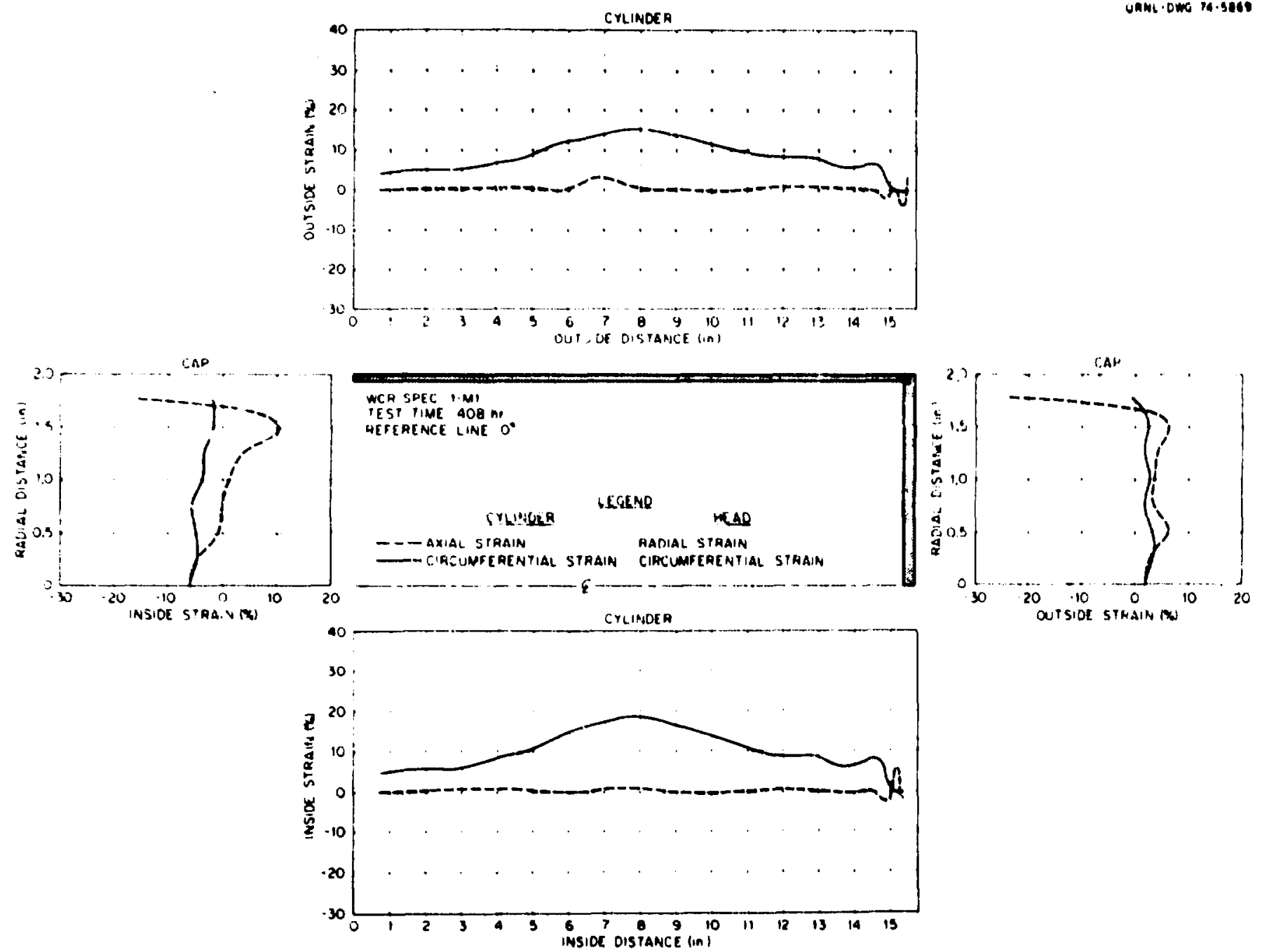

Fig. Al-a. Surface strain distribution for specimen 1-MI along the axial reference plane, $\theta=0^{\circ}$, at $408 \mathrm{hr}(1 \mathrm{in} .=2.54 \mathrm{~cm})$. 

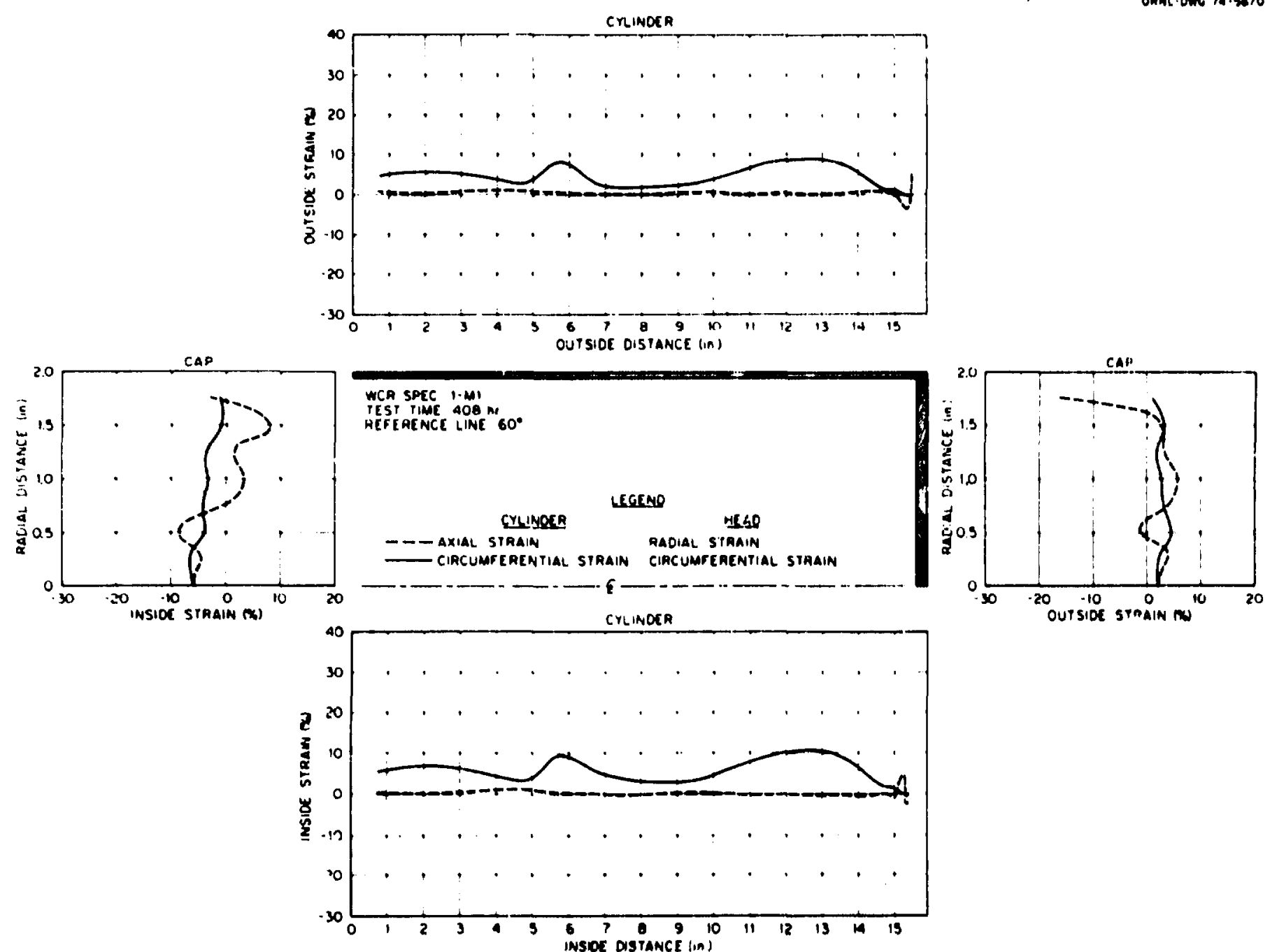

F1g. Al-b. Surface strain distribution for specimen 1-Ml along the axial reference plane, $\theta=60^{\circ}$, at $408 \mathrm{hr}(1 \mathrm{ln} .=2.54 \mathrm{~cm}$ ). 

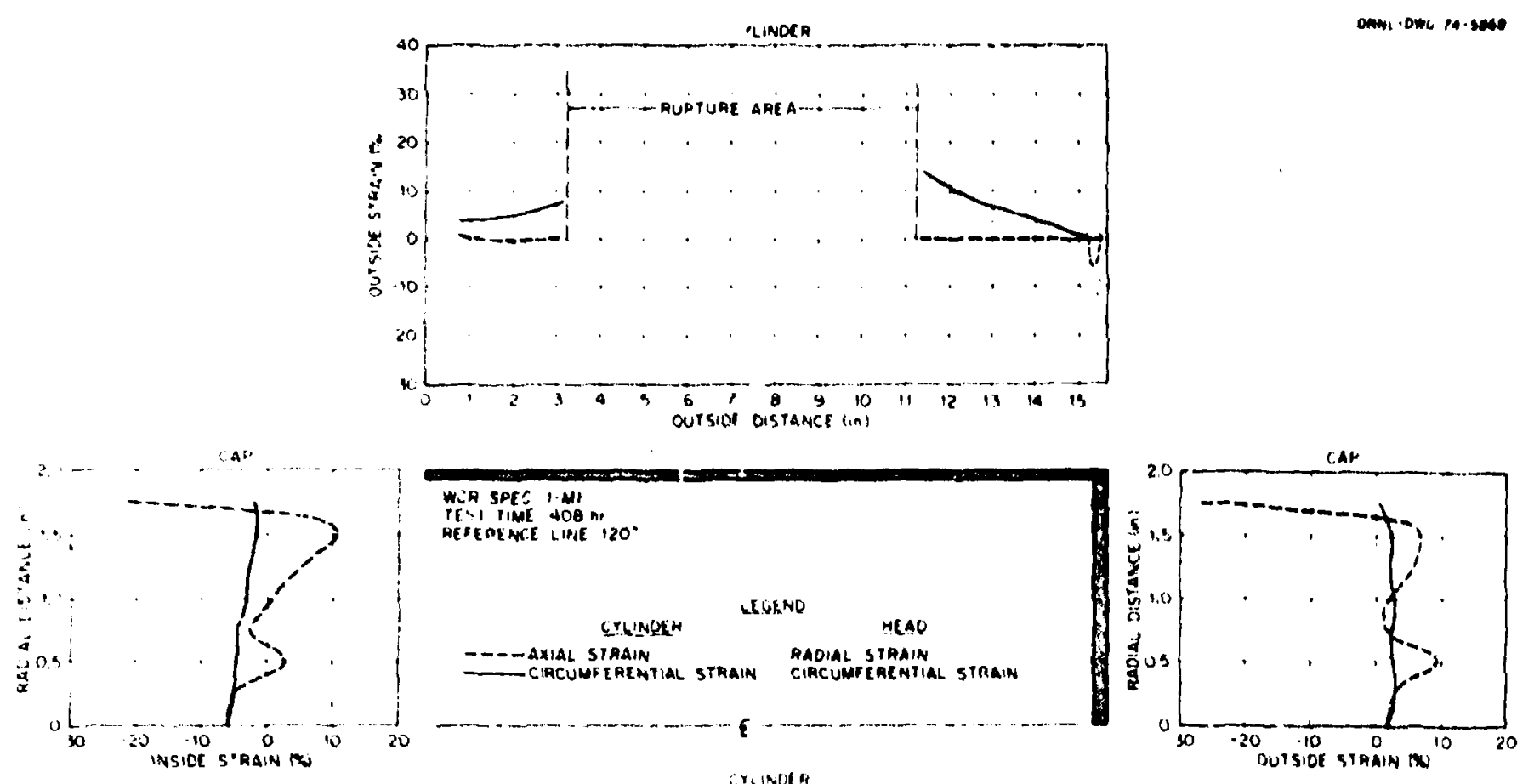

Fig. Al-c. Surface strain distribution for specinen 1-Ml along the axial reference plane, $\theta=120^{\circ}$, at $408 \mathrm{hr}(1 \mathrm{in}=2.54 \mathrm{~cm})$. 

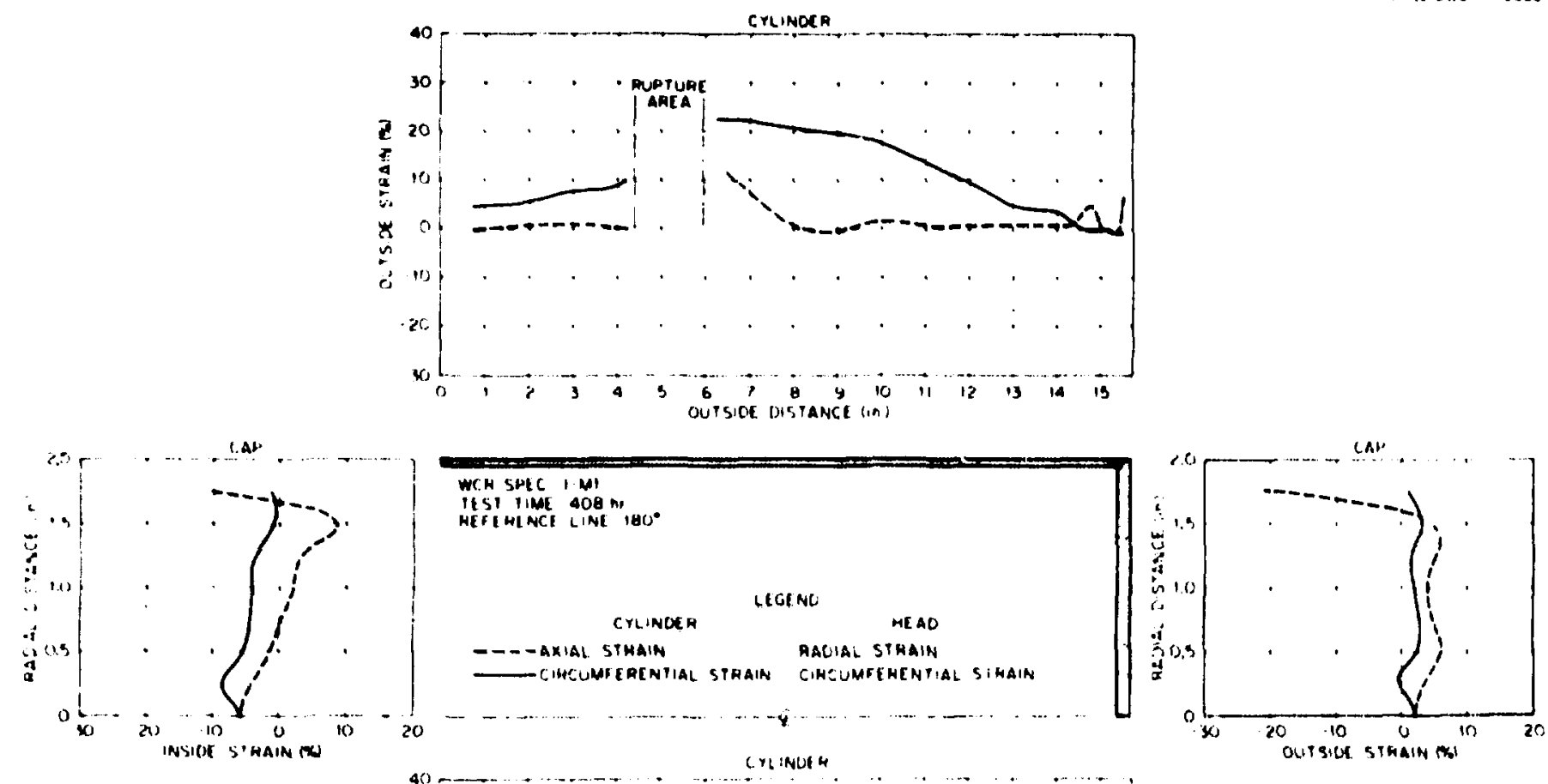

Fig. Al-d. Surface strain distribution for specimen l-MI along the axial reference plane, $\theta=180^{\circ}$, at $408 \mathrm{hr}(1 \mathrm{in} .=2.54 \mathrm{~cm})$. 

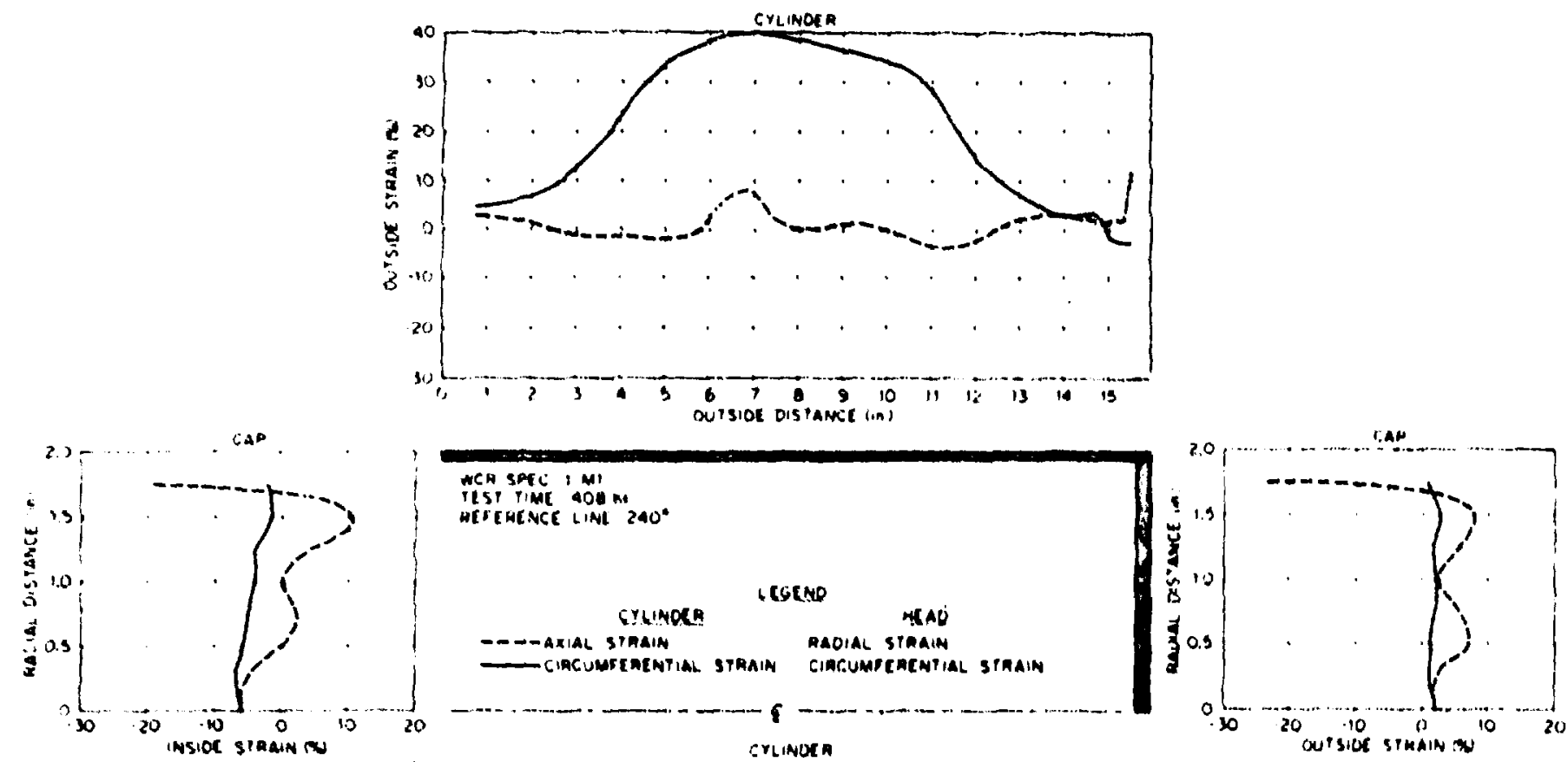

Fig. Al-e. Surface strain distribution for specimen l-MI along the axtal reference plane, $\theta=240^{\circ}$, at $408 \mathrm{hr}$ (1 $1 \mathrm{n} .=2.54 \mathrm{~cm}$ ). 

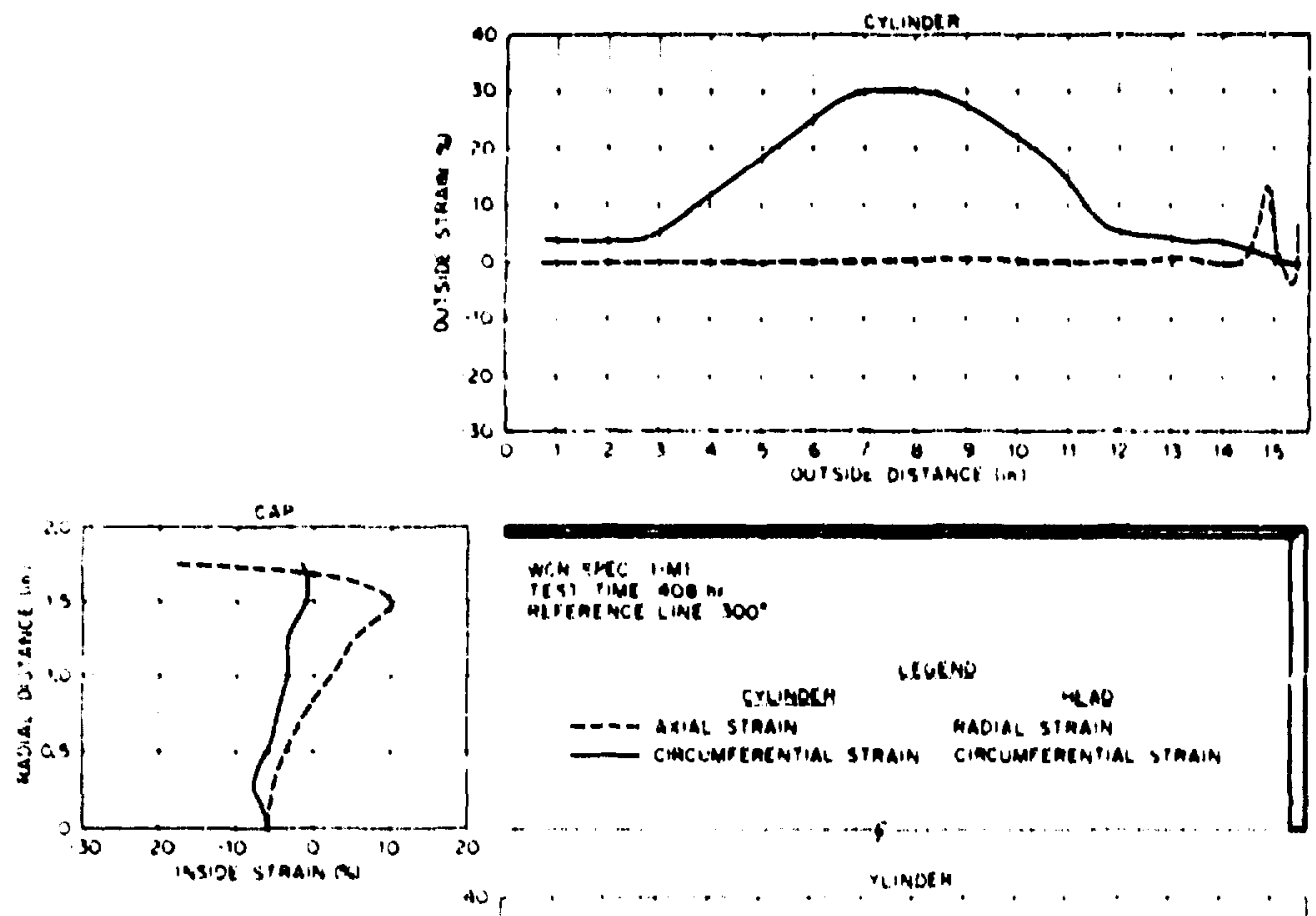

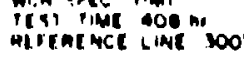

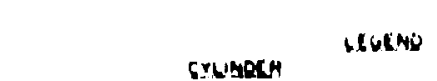

- - a dxist sinam

W6itis

MADIAL SIMATA

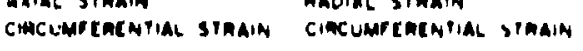
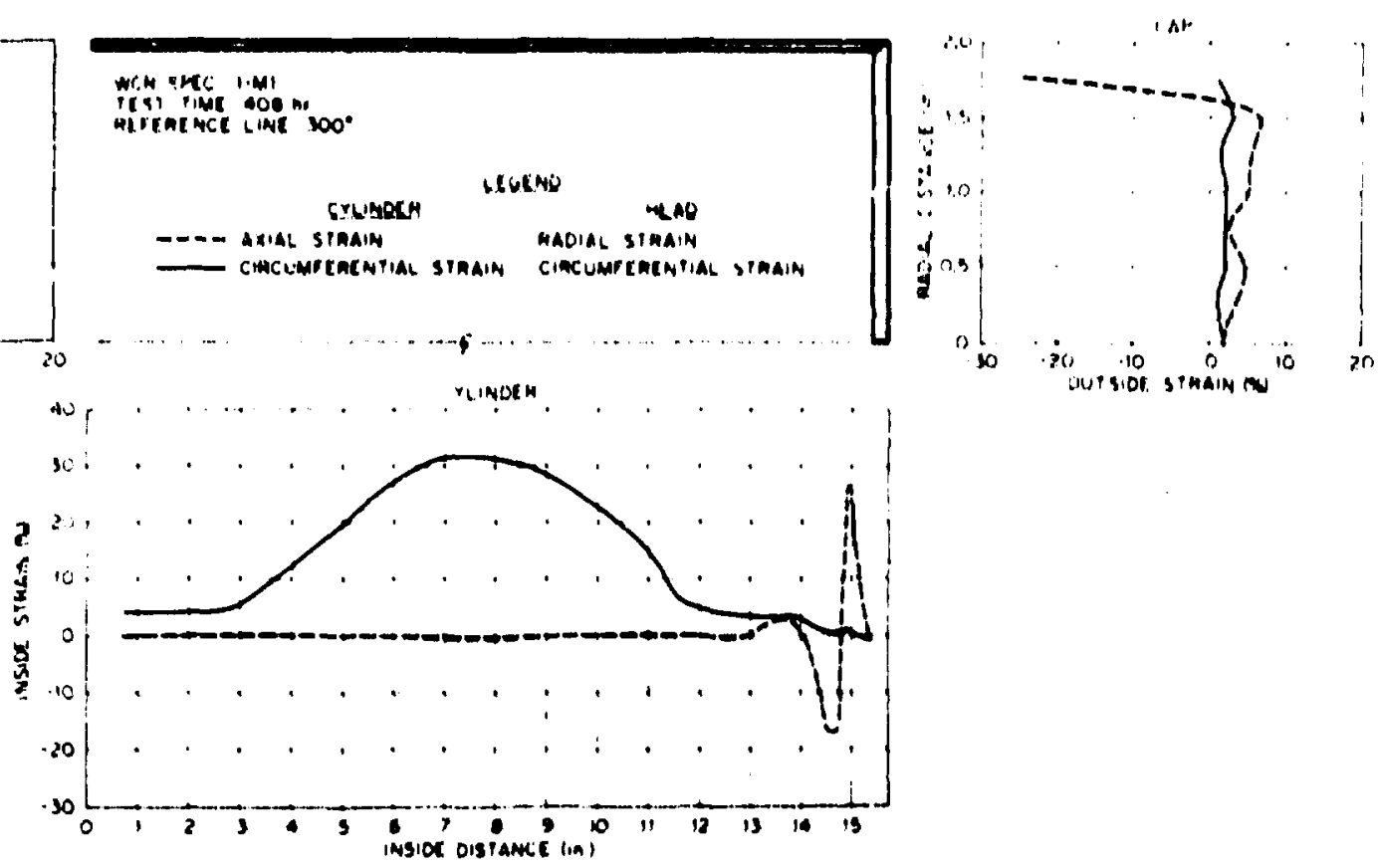

F1g. Al-f. Surface strain distribition for specimen 2-m along the axial reference plane, $\theta=300^{\circ}$, at $408 \mathrm{hl}$ ( I In. $=2.54 \mathrm{~cm}$ ). 

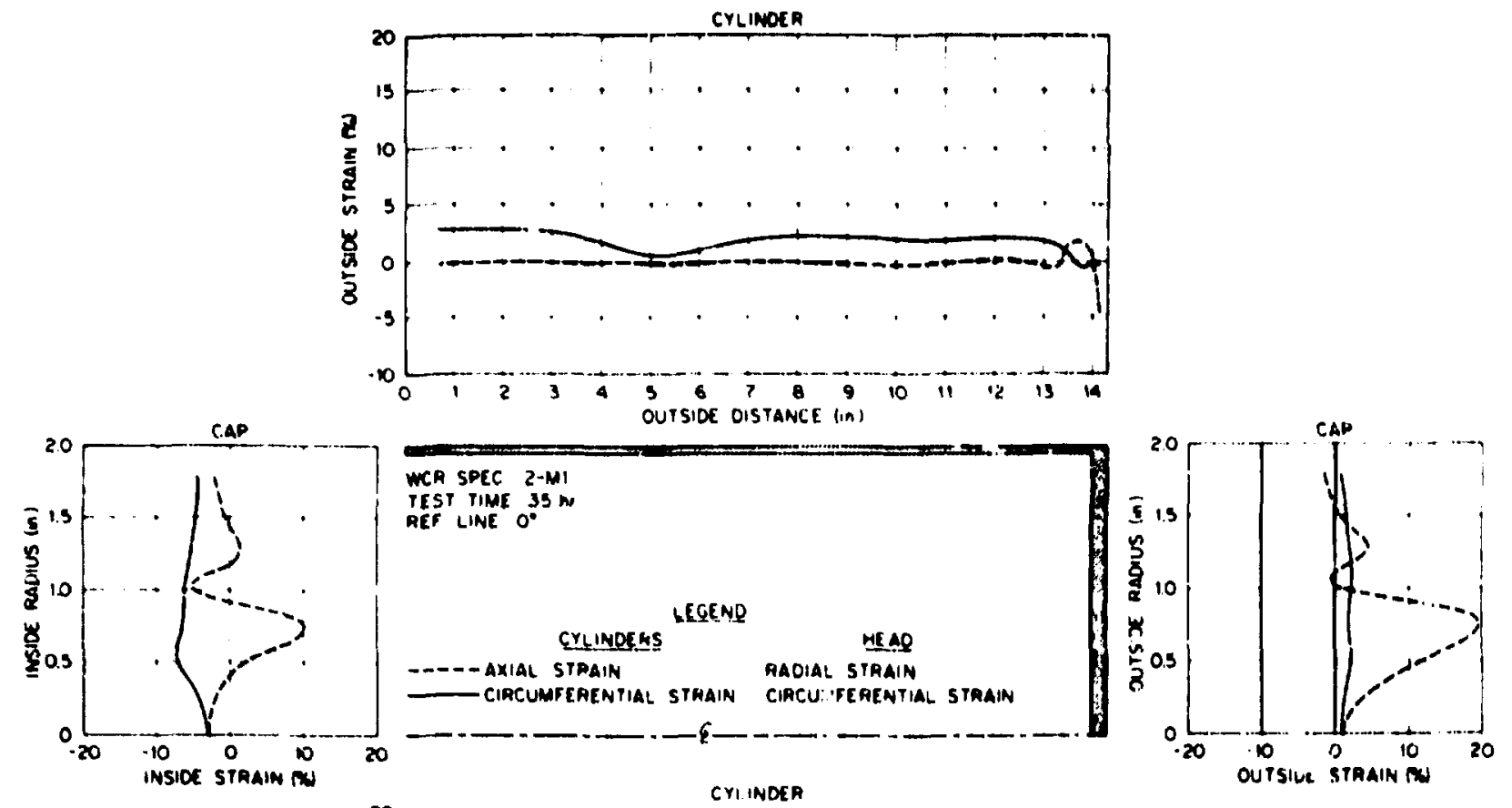

F1g. A2-a. Surface strain distribution for specimen 2-Mn along the axial rtference plane, $\theta=0^{\circ}$, at $35 \mathrm{hr}(1 \mathrm{in} .=2.54 \mathrm{~cm})$. 

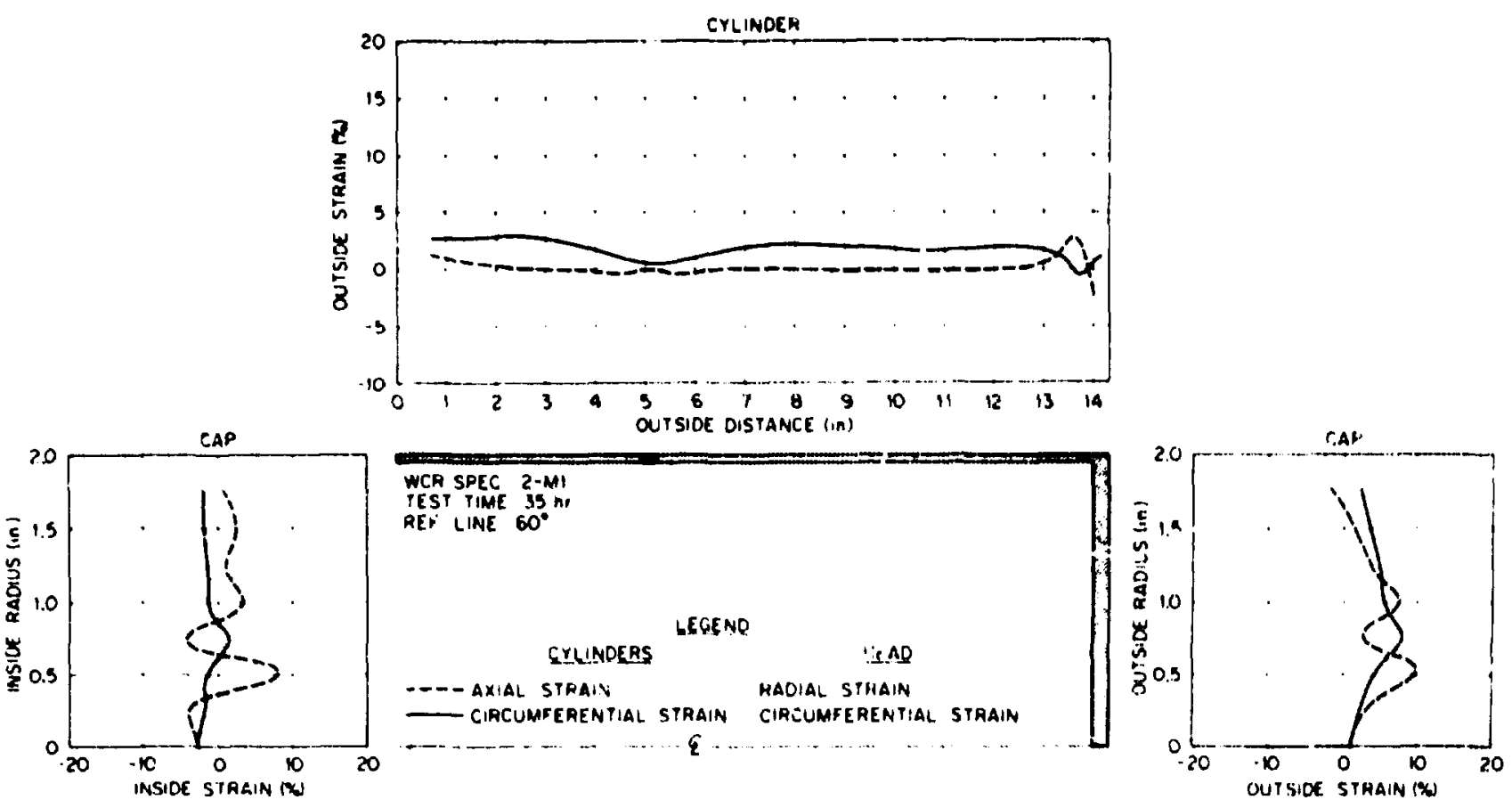

Fig. A2-b. Surface strain distribution for specimen 2-MI along the axial reference plane, $\theta=60^{\circ}$, at $35 \mathrm{hr}(1 \mathrm{in} .=2.54 \mathrm{~cm})$. 

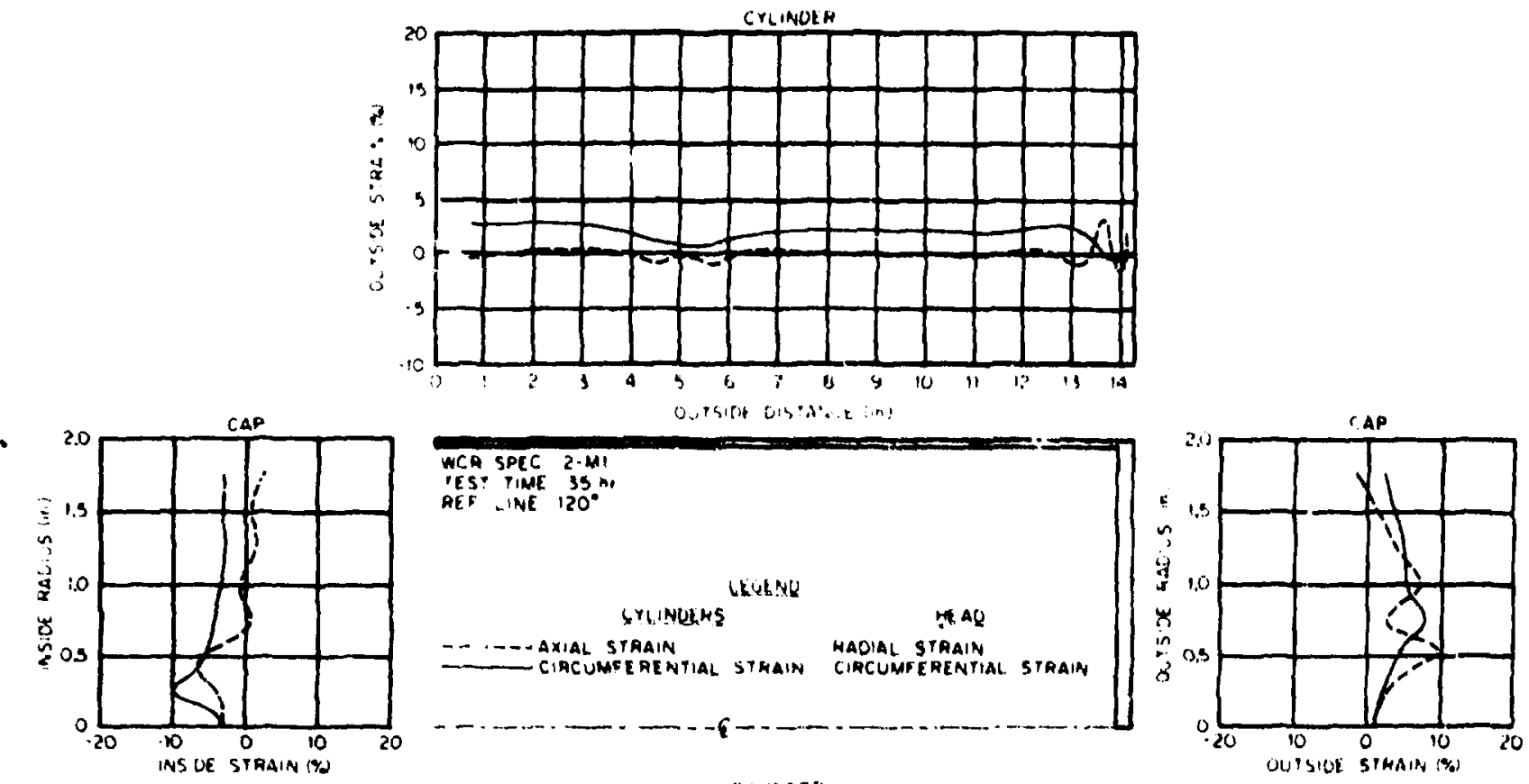

F1g. A2-c. Surface strain distribution for specimen 2-ill along the axial reference plane, $\theta=220^{\circ}$, at $35 \mathrm{hr}(1 \mathrm{in}$. $=2.54 \mathrm{~cm}$ ). 

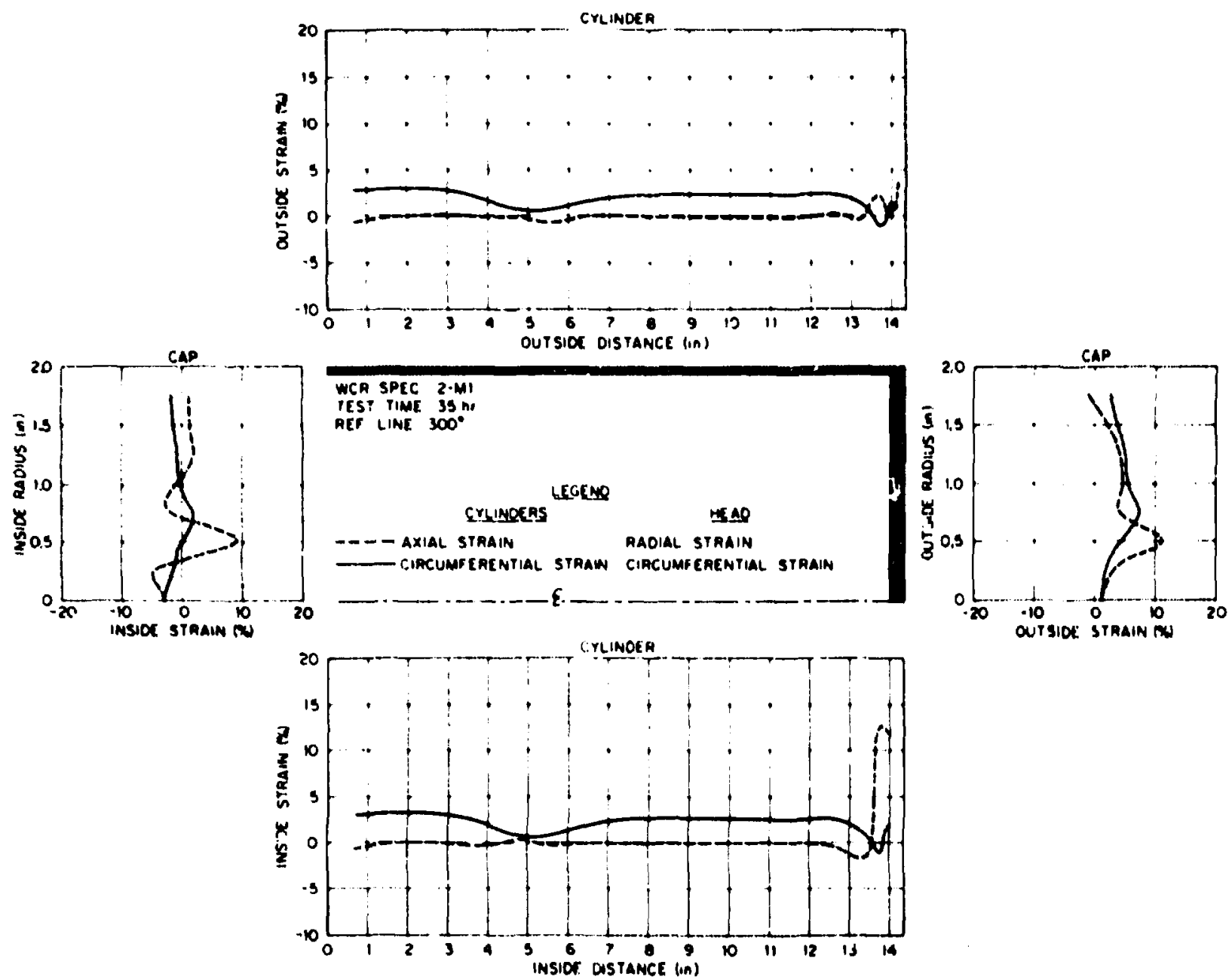

Fig. A2-d. Surface strain distribution for specimen 2-Mn along the axtal reference plane, $\theta=180^{\circ}$, at $35 \mathrm{hr}(1 \mathrm{ln} .=2.54 \mathrm{~cm})$. 

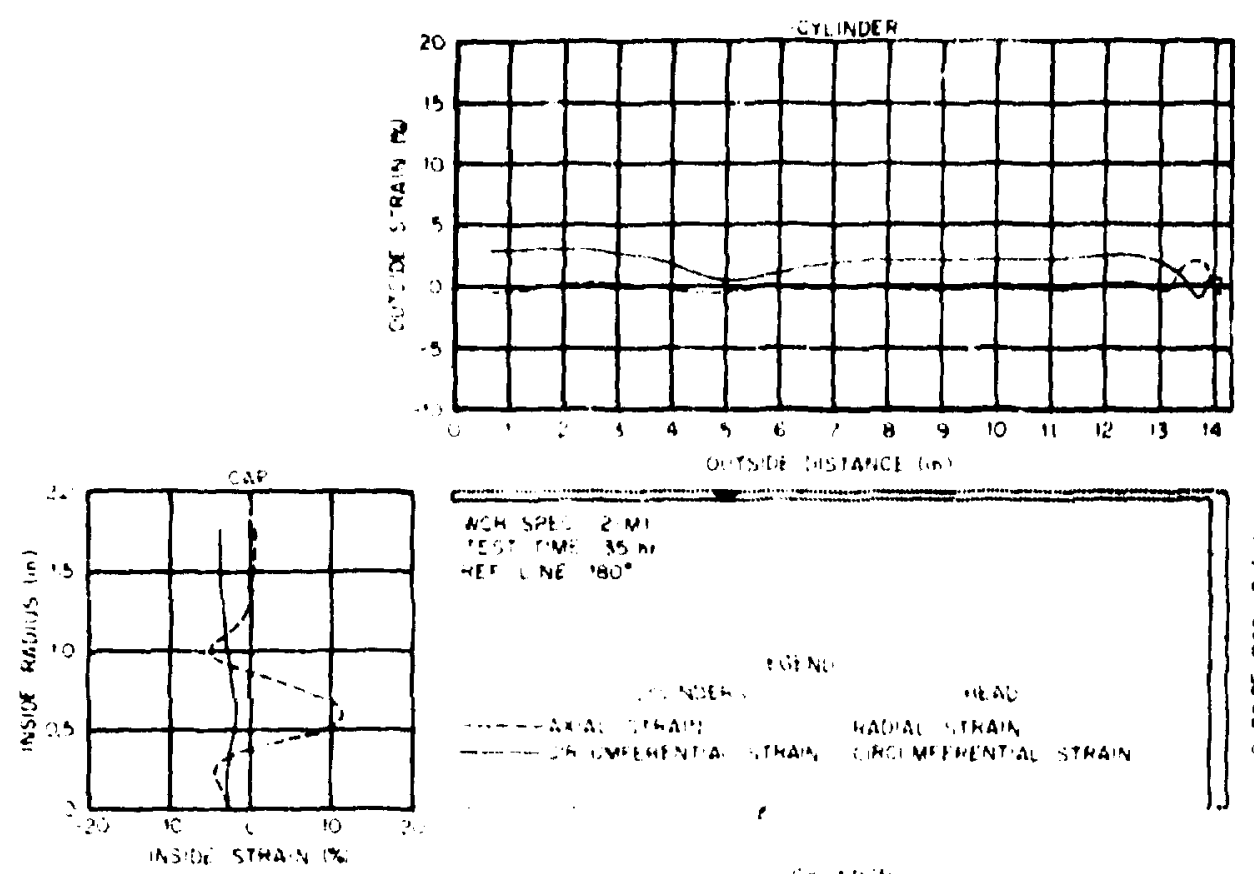

$$
\text { NCH STE } 2 \text { MN }
$$
QE. T NE $80^{\circ}$
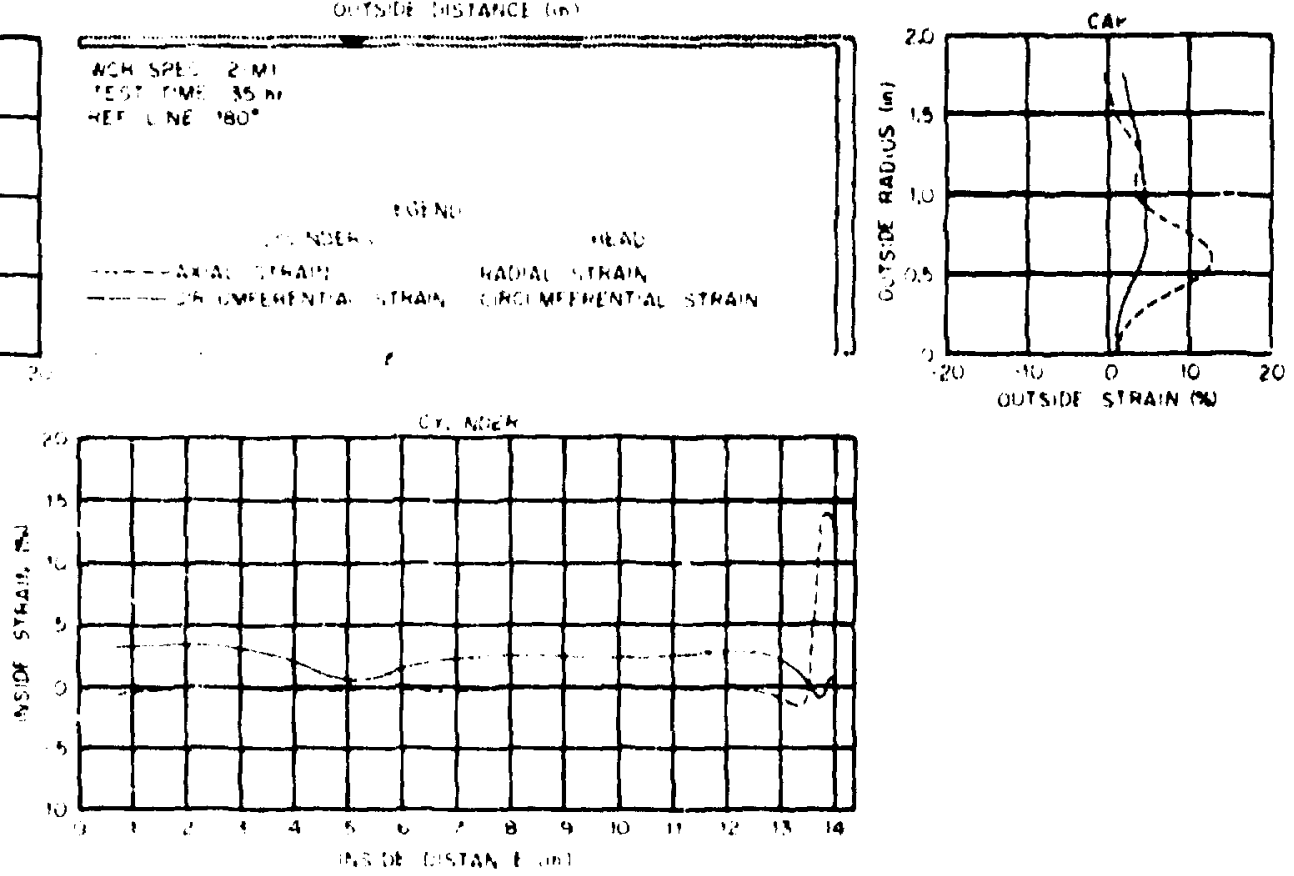

Fig. A2-e. Surface strain distribution for specimen 2-MI along the axial reference plane, $\theta=240^{\circ}$, at $35 \mathrm{hr}(1 \mathrm{in} .=2.54 \mathrm{~cm})$. 

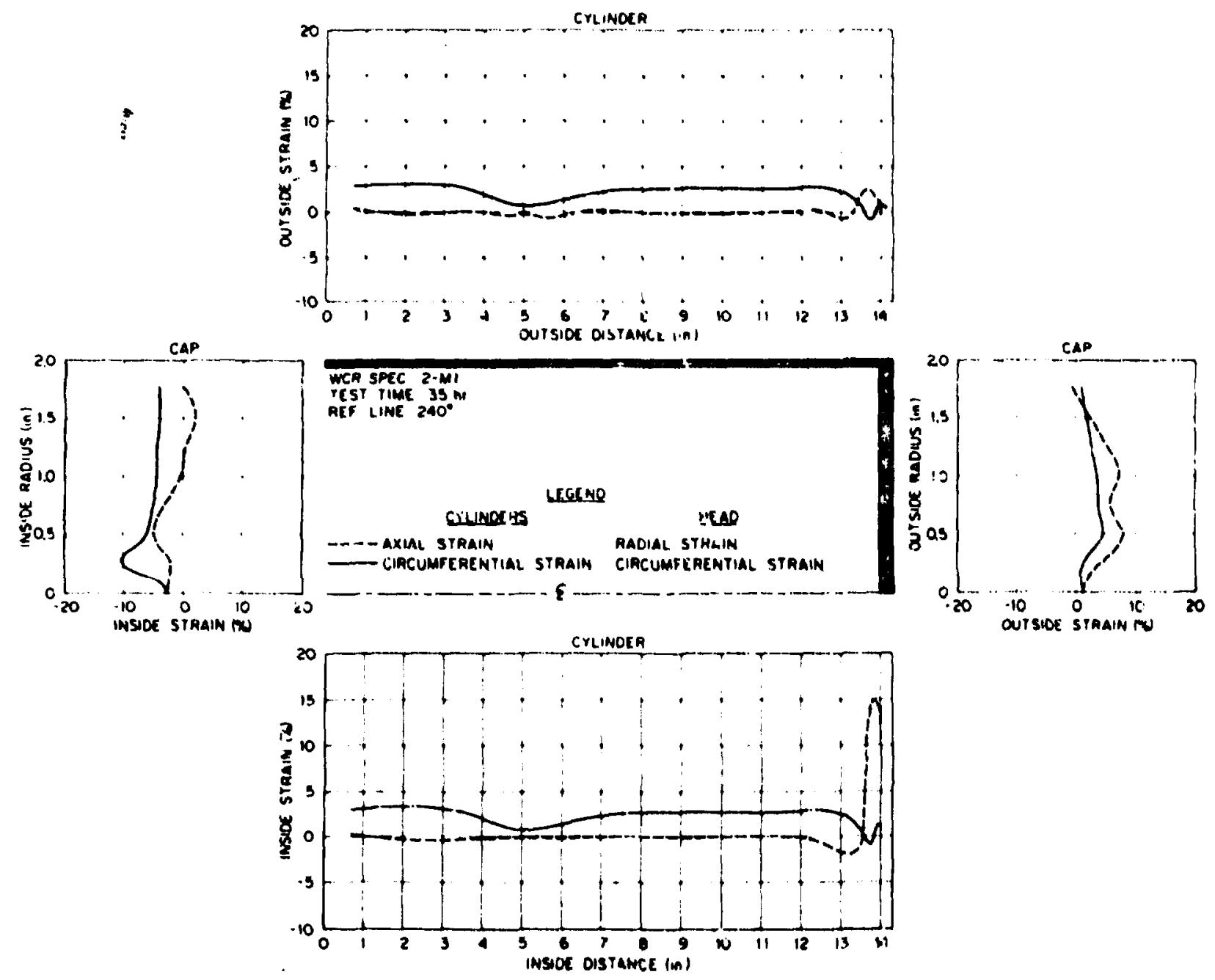

F1g. A2-f. Surface strain distribution for specimen 2-MI along the axial reference plane, $\theta=300^{\circ}$, at $35 \mathrm{hr}$ (1 in. $=2.54 \mathrm{~cm}$ ). 

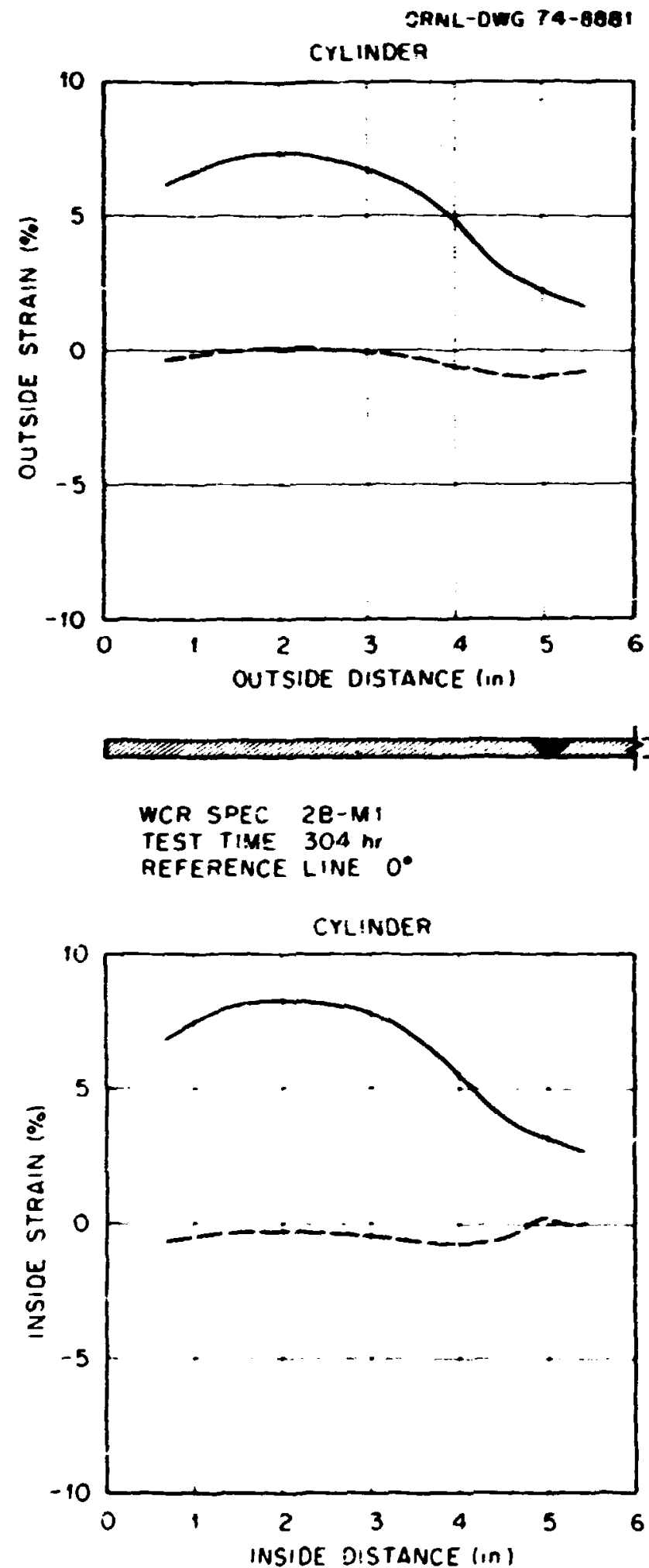

Fig. A3-a. Surface strain distribution for specimen 2B-M along the axial reference plane, $\theta=0^{\circ}$, at $304 \mathrm{hr}(1 \mathrm{in} .=2.54 \mathrm{~cm})$. 

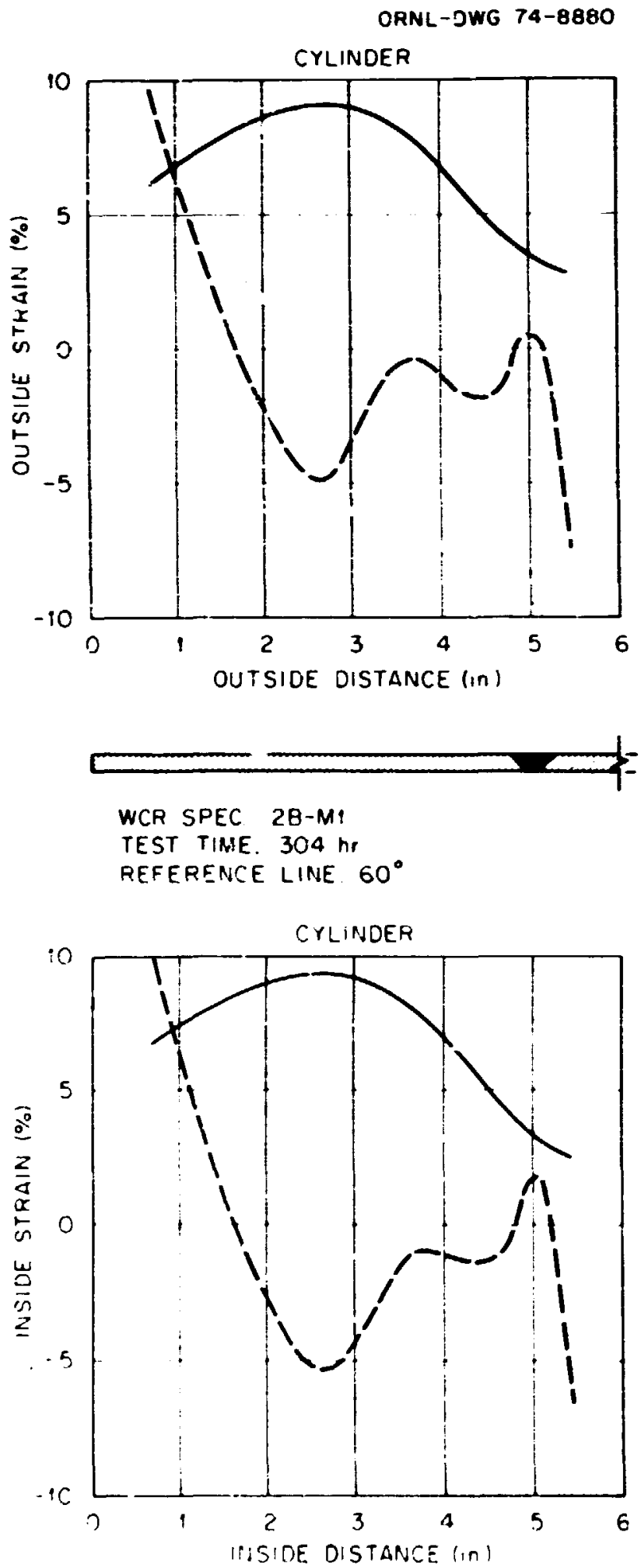

F1g. A3-b. Surface strain distribution for specimen $2 B-M 1$ alung the axial reference plane, $\theta=60^{\circ}$, at $304 \mathrm{hr}(1 \mathrm{in} .=2.54 \mathrm{~cm})$. 

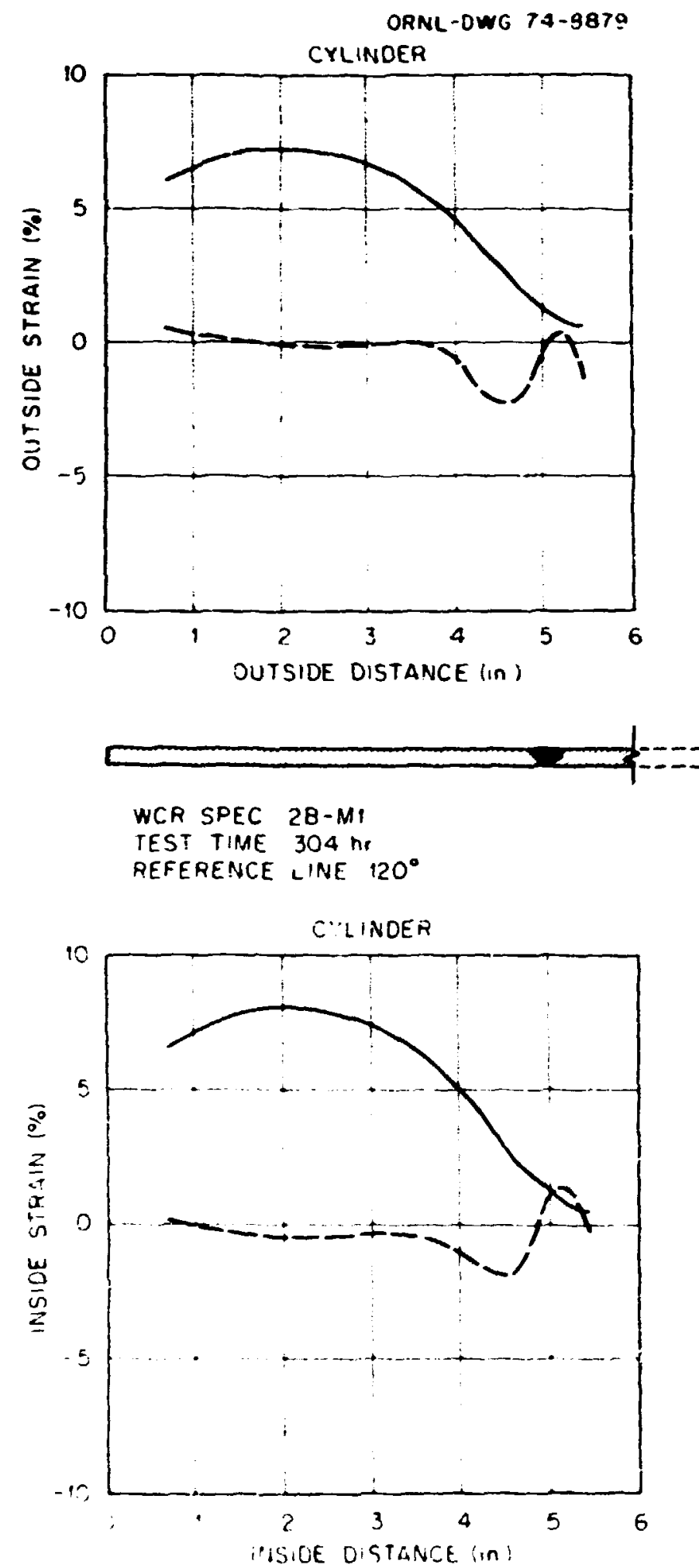

Fig. A3-c. Surface strain distribution for specimen $2 B-M 1$ along the axial reference plane, $\theta=120^{\circ}$, at $304 \mathrm{hx}$ ( I in. $=2.54 \mathrm{~cm}$ ). 

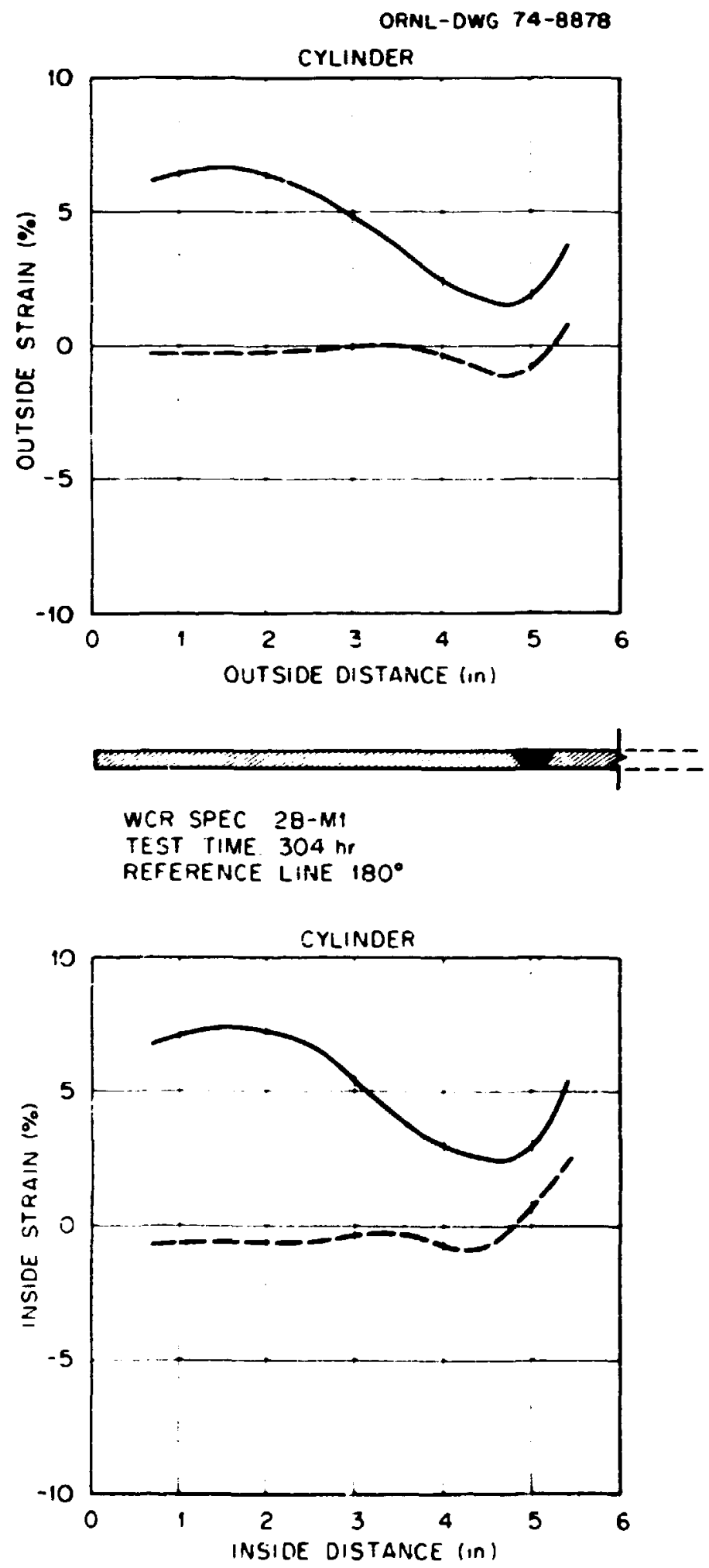

Fig. A3-d. Surface strain distribution for specimen $2 B-M 1$ along the axial reference plane, $\theta=180^{\circ}$, at $304 \mathrm{hr}(1 \mathrm{in} .=2.54 \mathrm{~cm})$. 

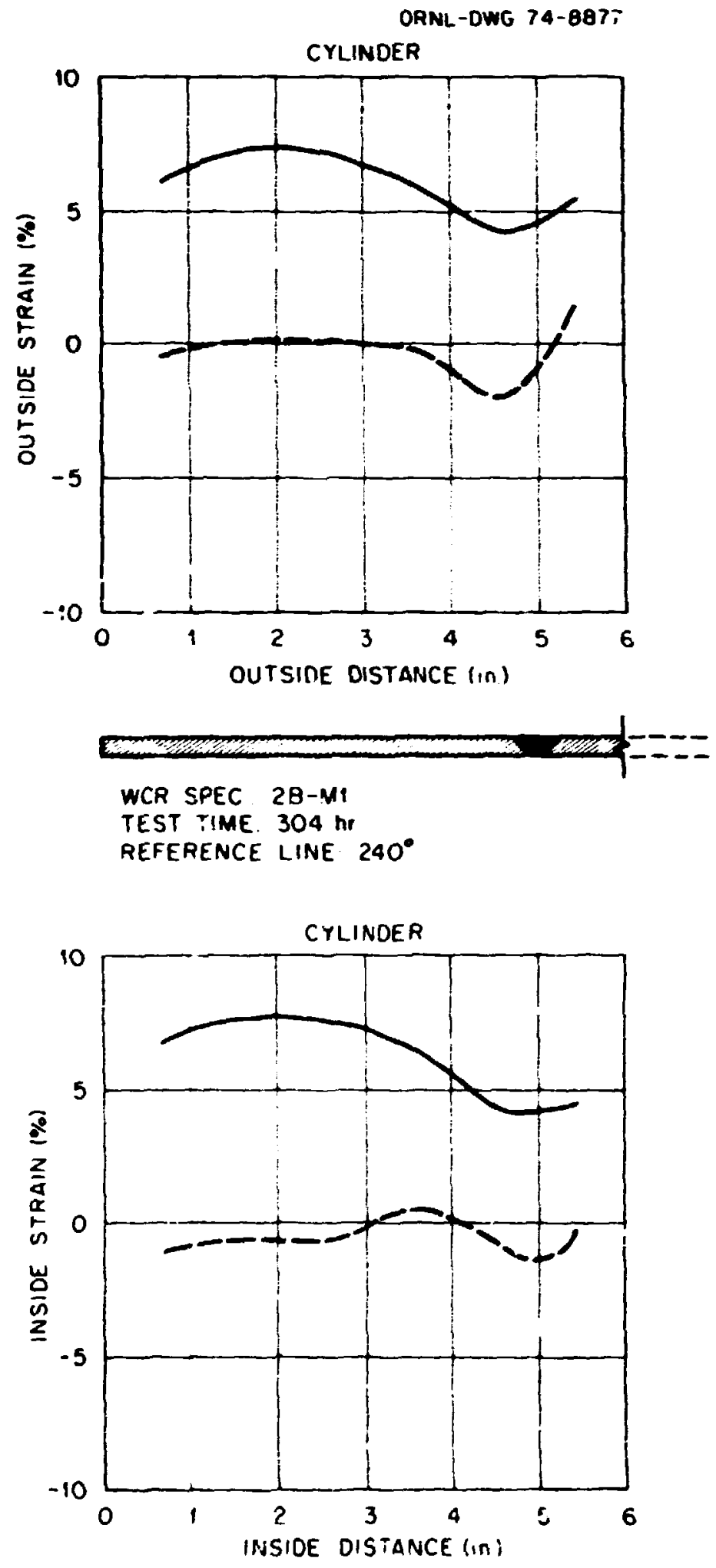

Fig. A3-e. Surface strain distribution for specimen $2 B-M I$ along the axlal reference plane, $0=240^{\circ}$, at $30 \mathrm{~h} \mathrm{hr}(1 \mathrm{in} .=2.54 \mathrm{~cm}$ ). 
ORNL-DWG 74-8876
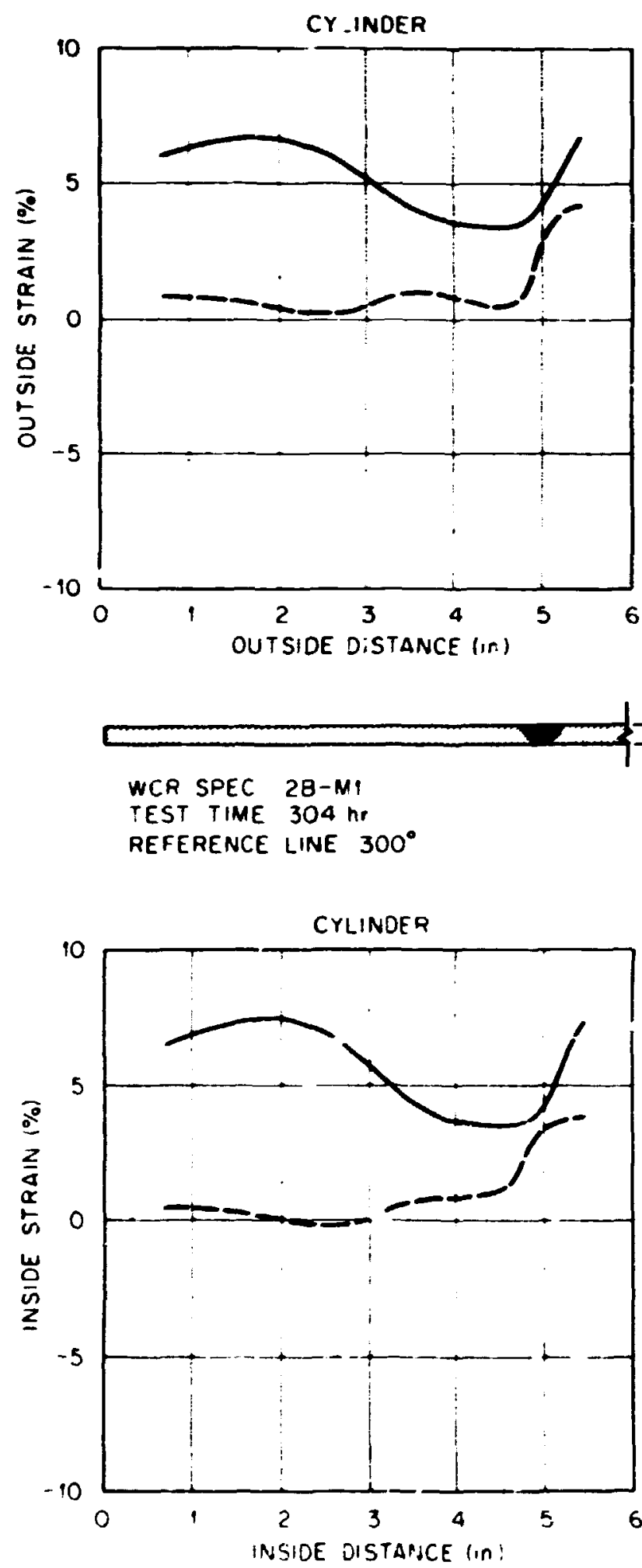

P1g. A3-f. Surface strain distribution for specimen 2B-Ml along the axial reference plane, $\theta=300^{\circ}$, at $304 \mathrm{hr}(1 \mathrm{in} .=2.54 \mathrm{~cm}$ ). 


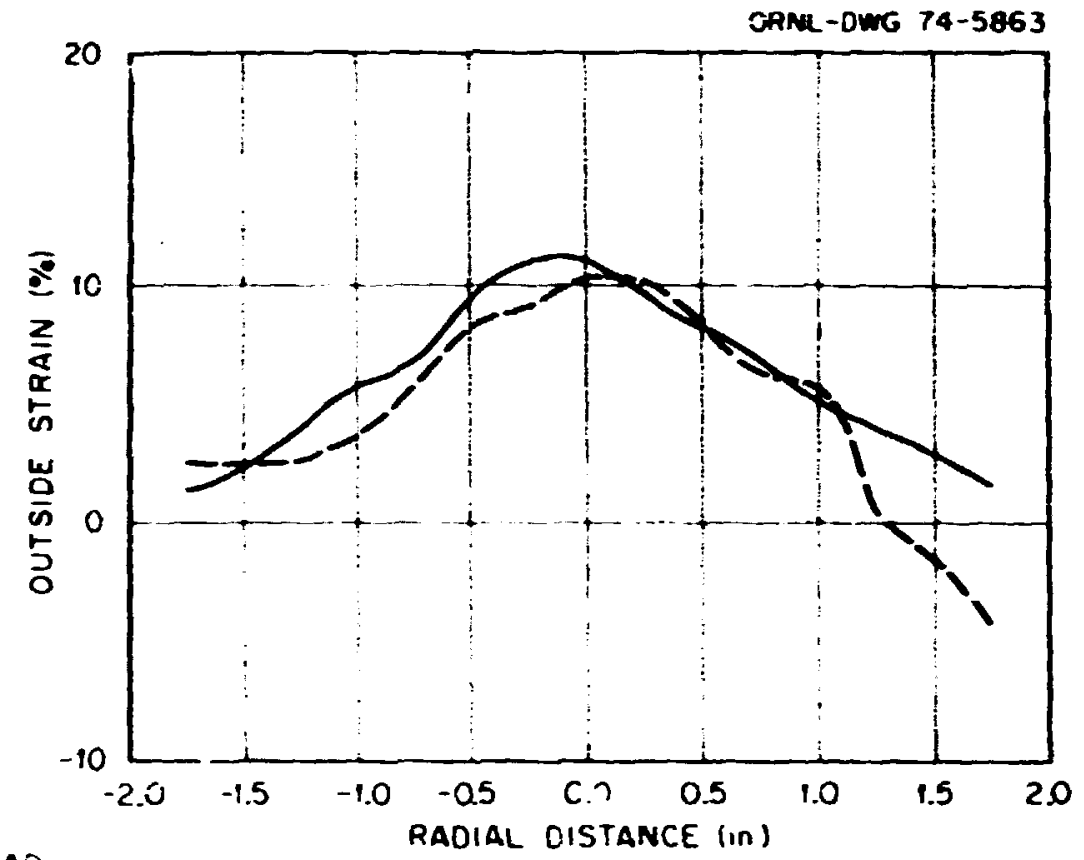

WCR SPEC 3-MI HEAD

TEST TIME $43 \mathrm{hr}$ REFERENCE DIAM: $0-180^{\circ}$

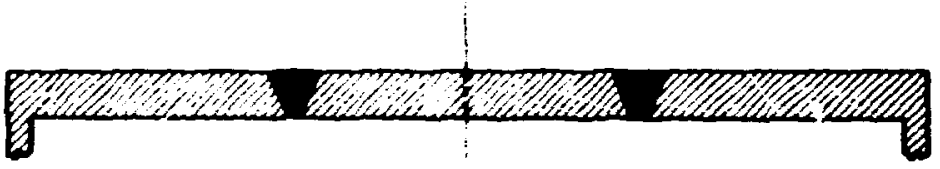

LEGEND

- - RADIAL STRA:A

- CIRCUMFERIPTIAL STRAIN

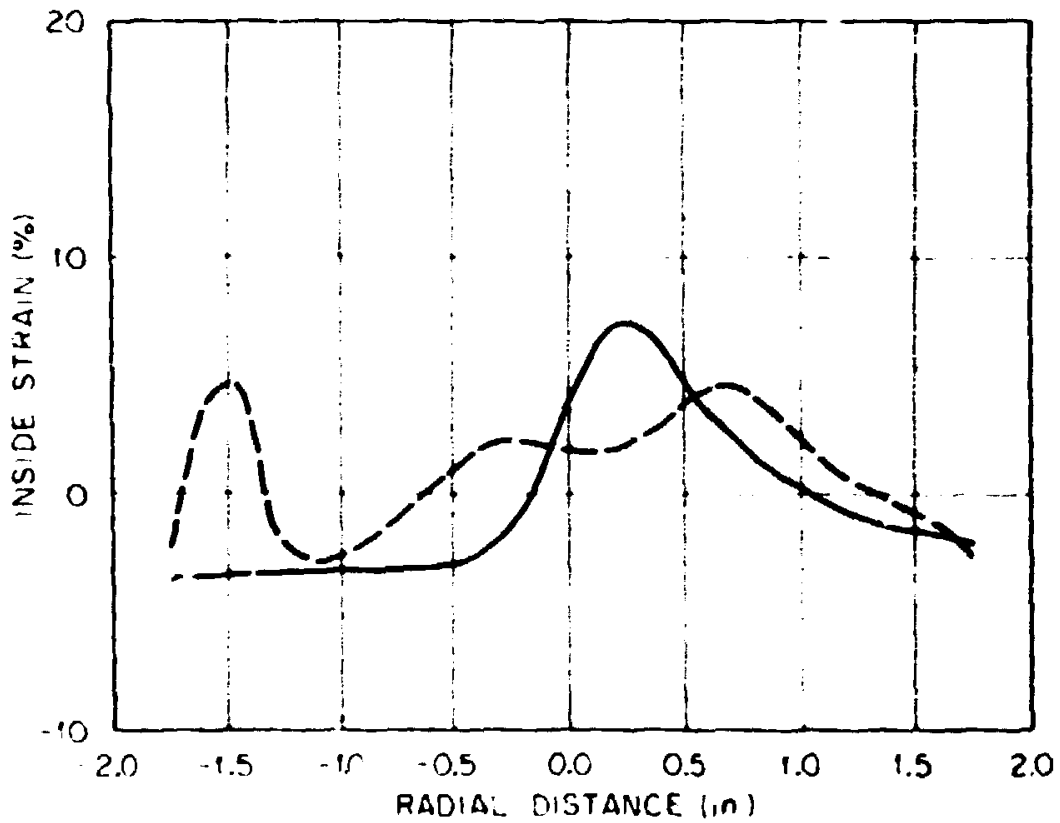

Fig. A4-8. Surface strain distribution on the head of specimen 3-Ml along the diameter, $0-180^{\circ}(1 \mathrm{in} .=2.54 \mathrm{~cm})$. 


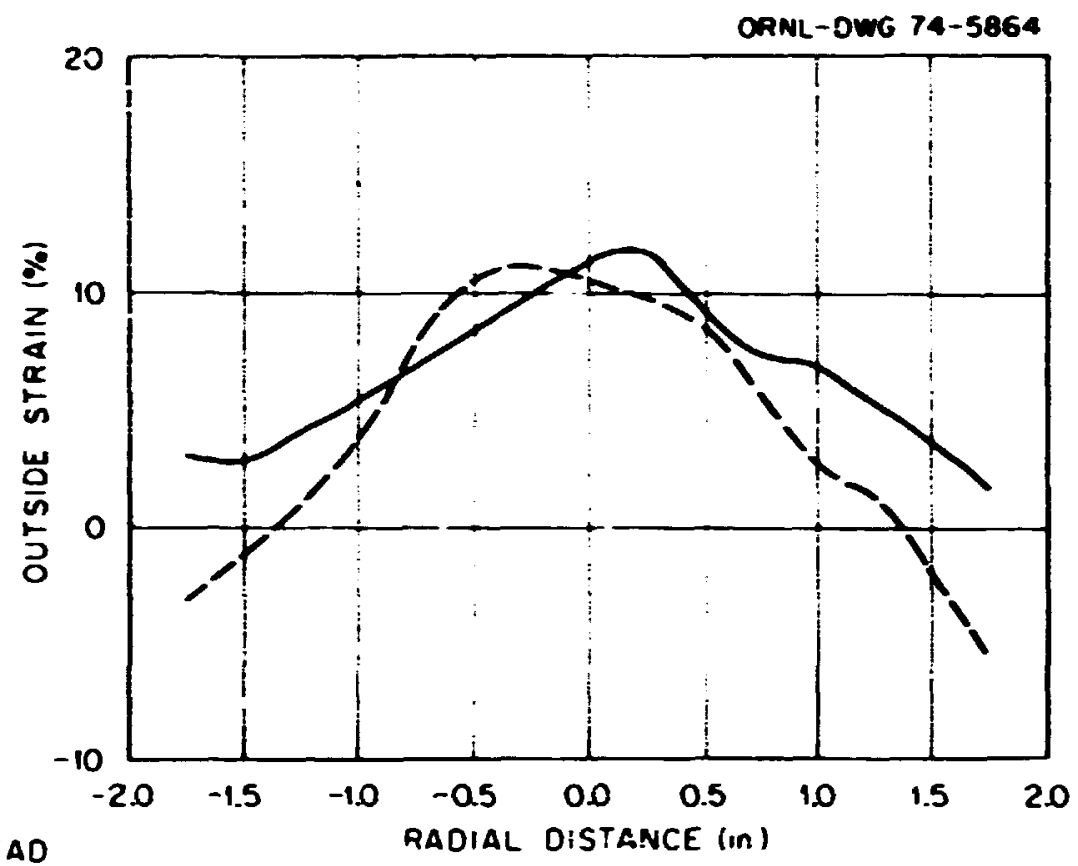

WCR SPEC 3-MI H:AD

TEST TIMS $43 \mathrm{mr}$

REFERENCE DIAM EO- $240^{\circ}$

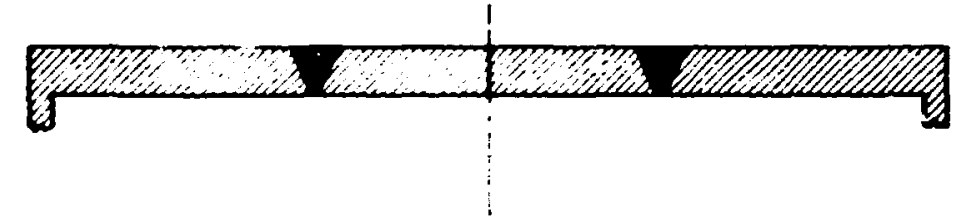

- - RADIAL STRAIN

CIRCUMFERENTIAL STRAIN

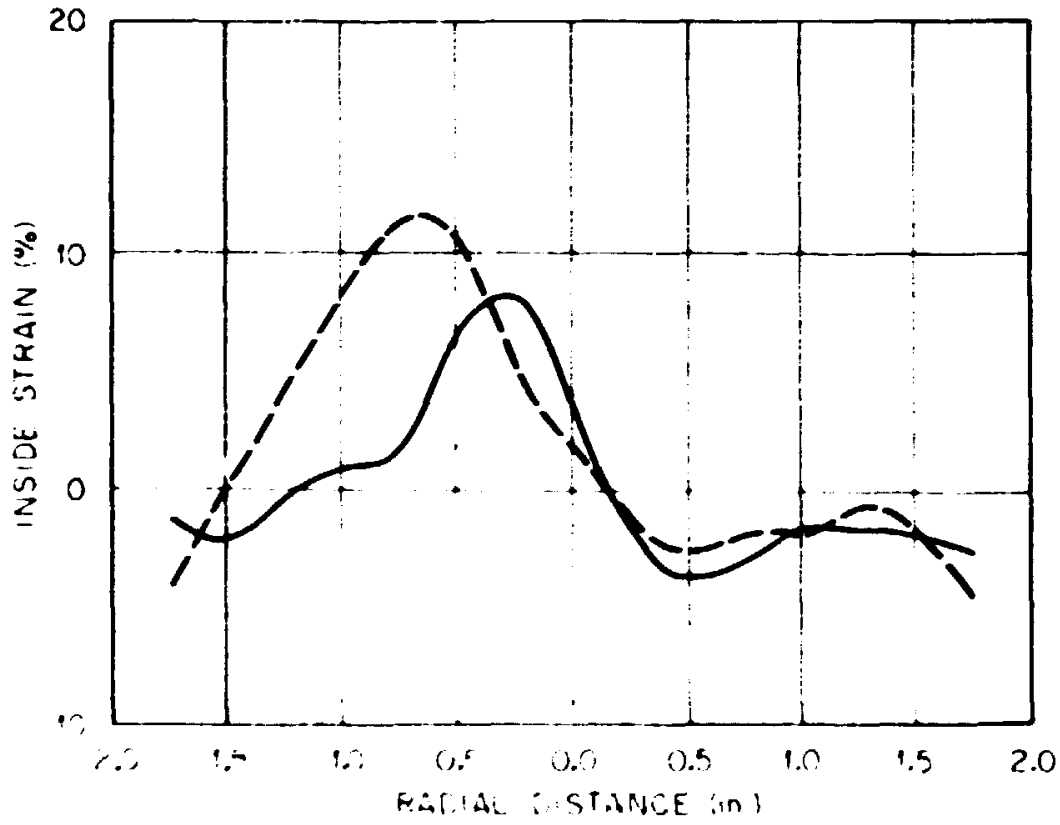

Fig. A4-b. Surface strain distribution on the head of specimen 3-Mn along the diameter, $60-240^{\circ}(1 \mathrm{in} .=2.54 \mathrm{~cm})$. 


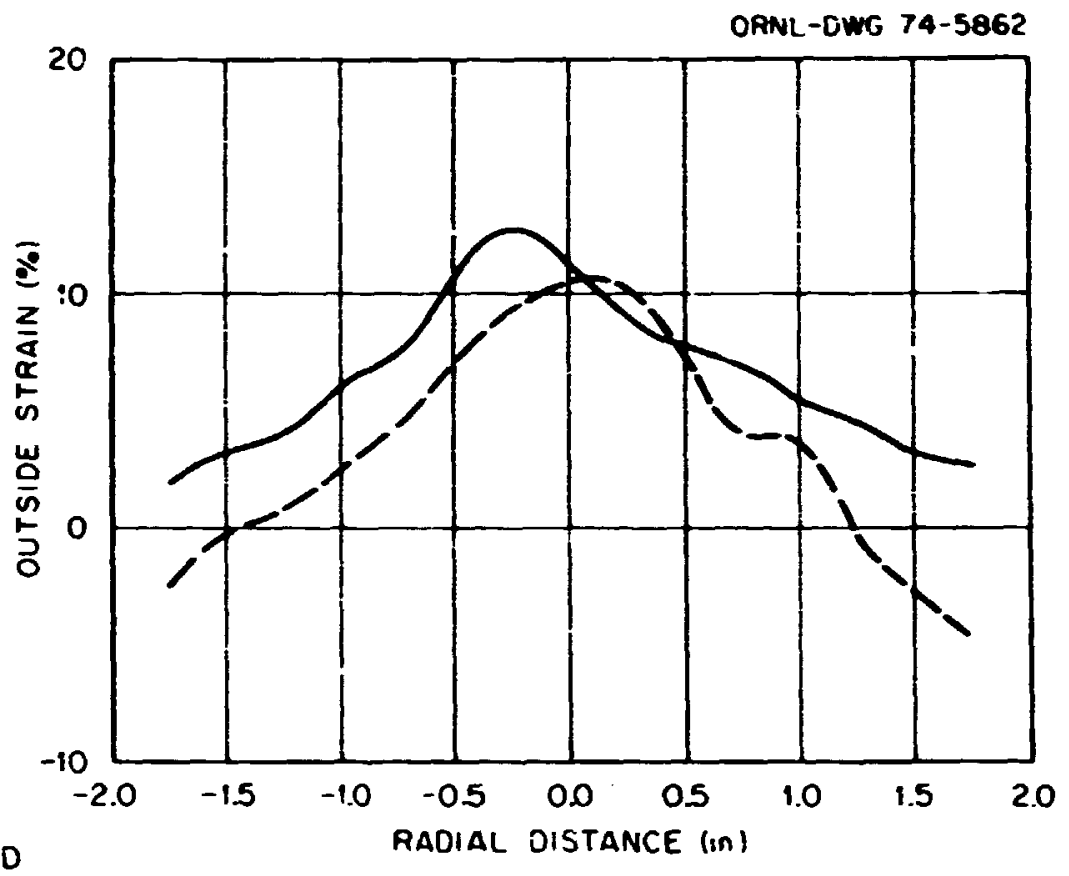

WCR SPEC 3-M: HEAD TEST TIME $43 \mathrm{hr}$ REFERENCE DIAM $120-300^{\circ}$

LEGENO

- RAOIAL STRAIN

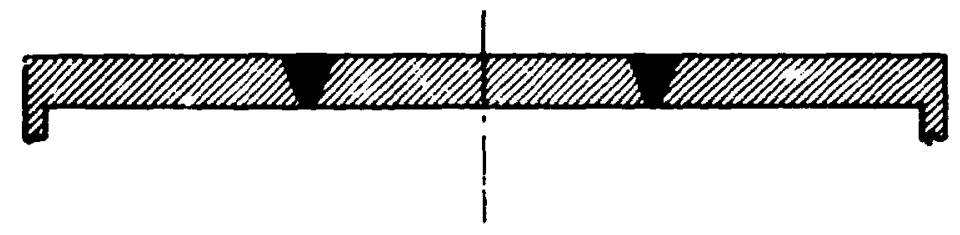

CIRCUMFERE'JTIAL STRAIN

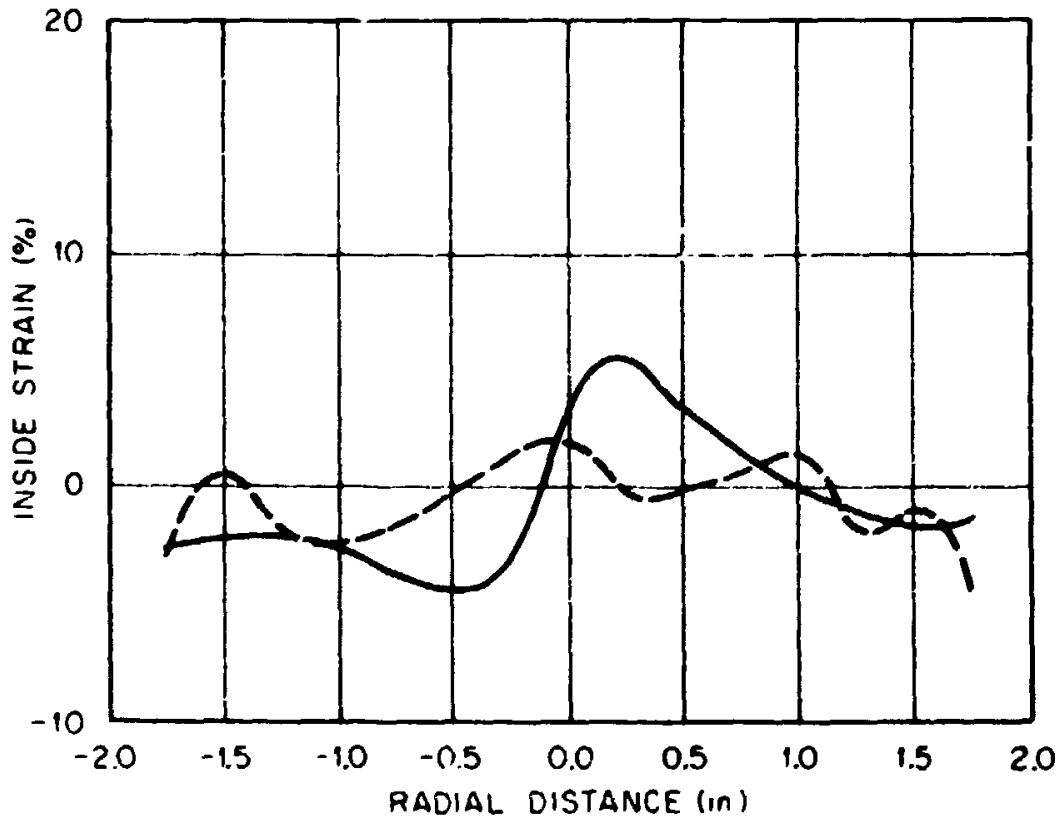

Fig. A4-c. Surface strain distribution on the head of specimen 3-Mn along the diameter, $120-300^{\circ}$ ( 1 in. $=2.54 \mathrm{~cm}$ ). 

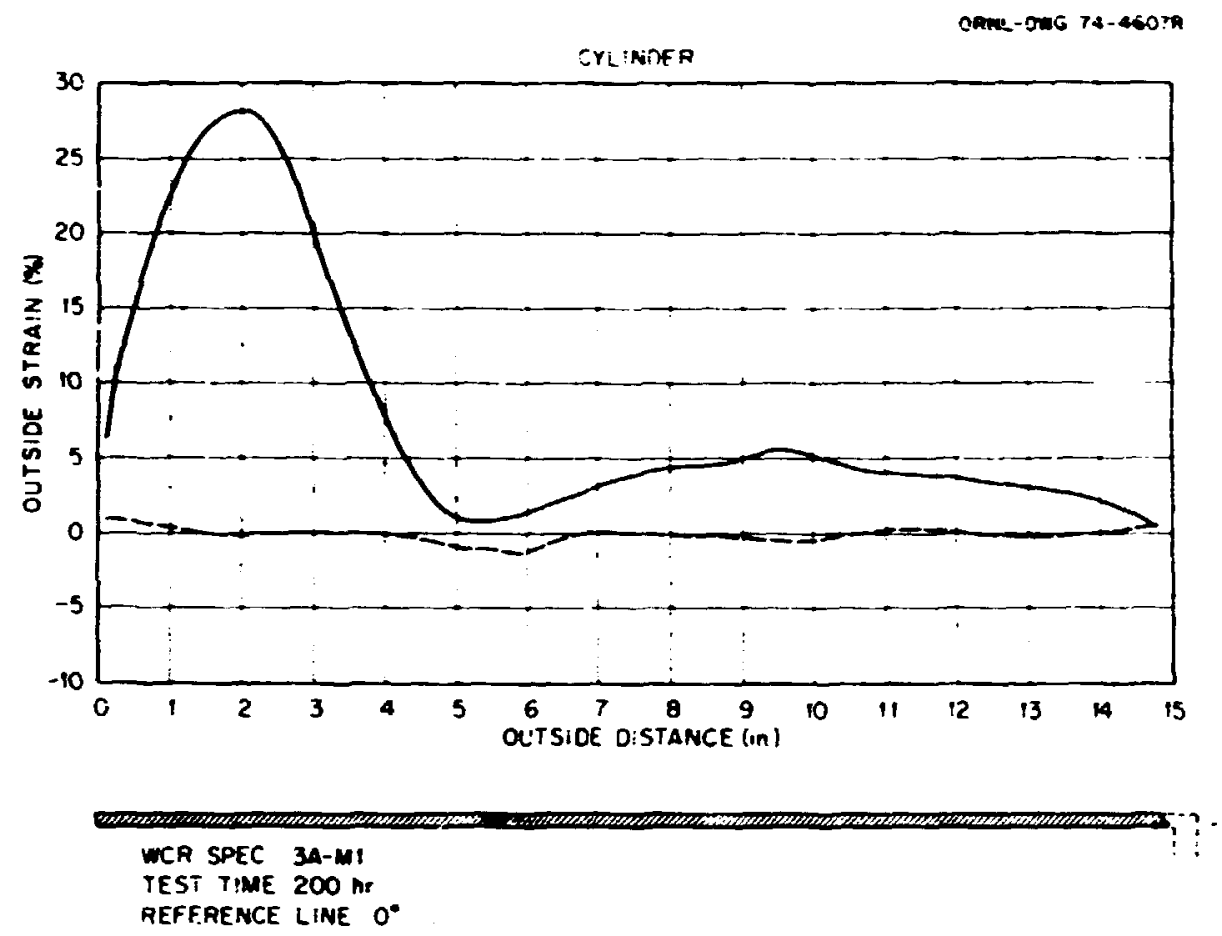

LEGEND

- - AXIAL STRA'

- CIRCUMFEREATIAL STRAIN

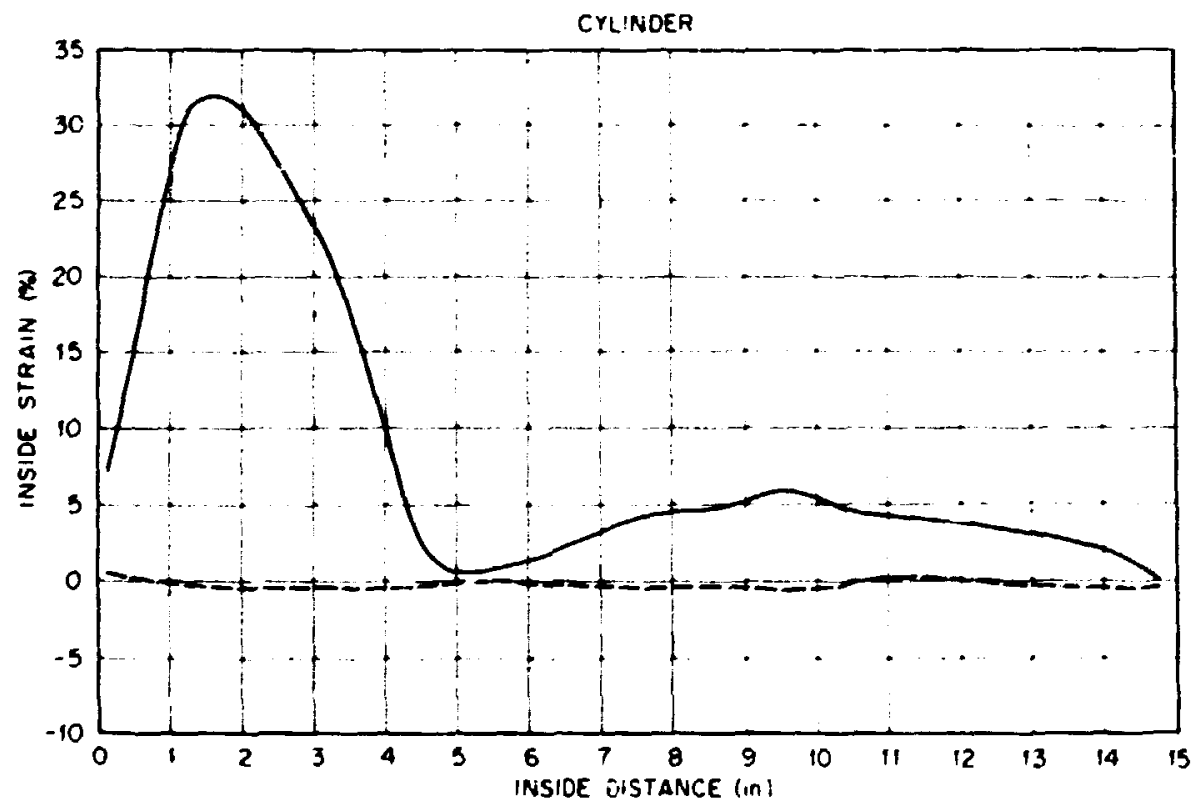

Fig. A5-a. Surface strain distribution for specimen $3 A-M$ along the axial reference plane, $\theta=0^{\circ}$, at $200 \mathrm{hr}(1 \mathrm{in} .=2.54 \mathrm{~cm})$. 


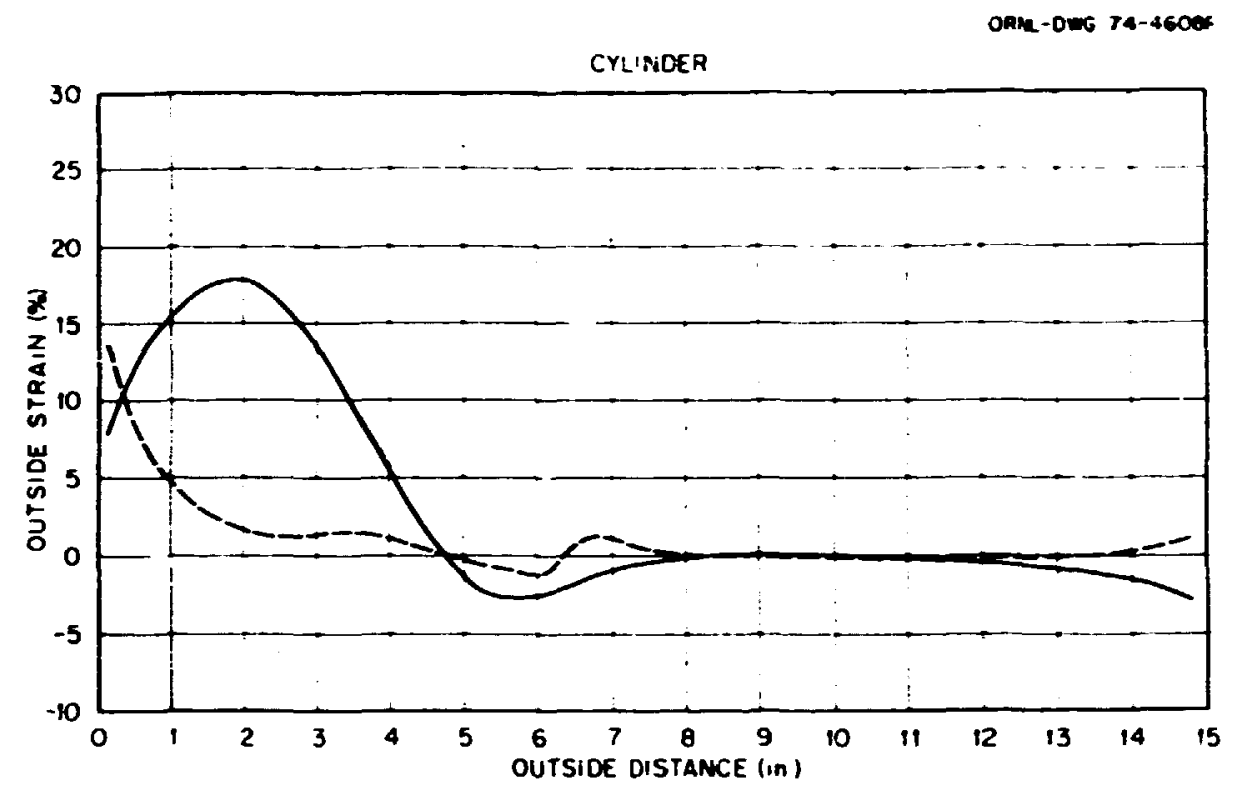

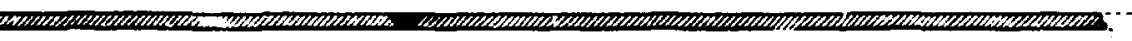

WCR SPEC 3A-M1

TEST TIME $200 \mathrm{ME}$

REFERENCE LINE $60^{\circ}$

LEGE ND

- DXIAL STRAIN

- CIRCUMFERENTIAL STRAIN

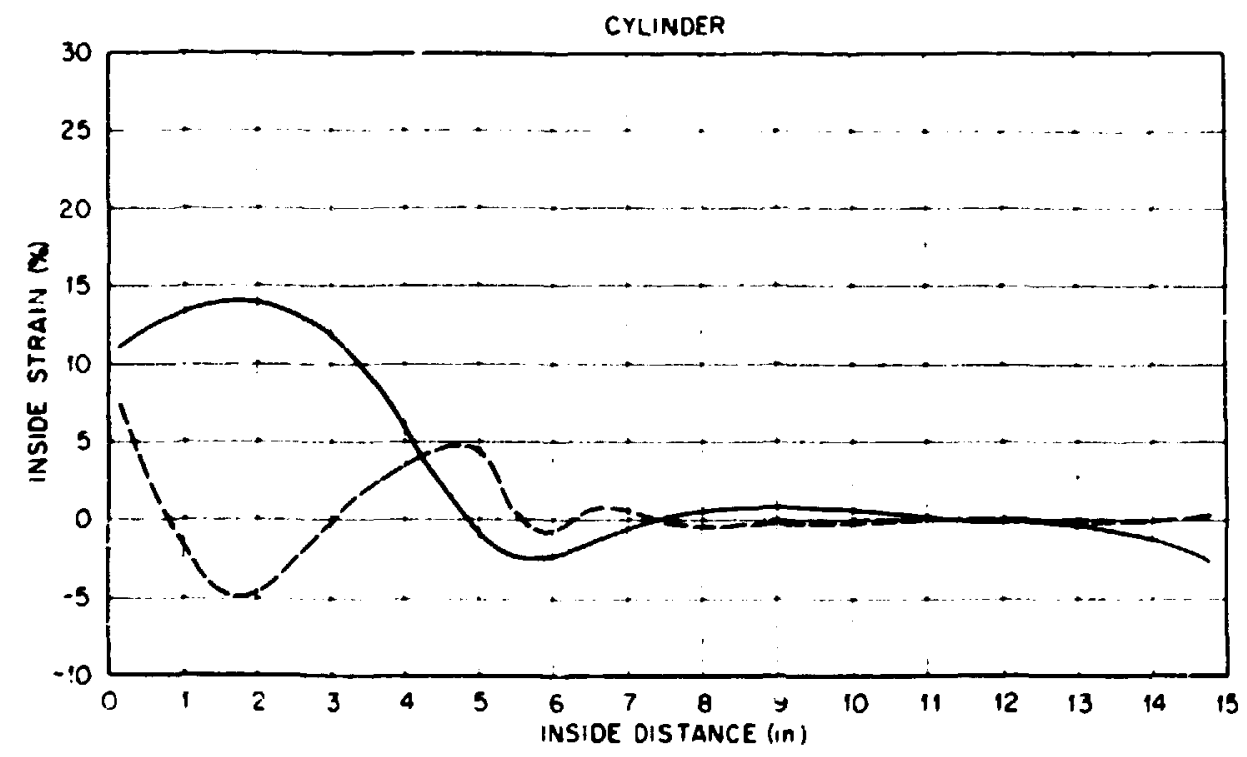

Fig. A5-b. Surface strain distribution for specimen 3A-MI along the axtal reference plane, $\theta=60^{\circ}$, at $200 \mathrm{hr}(1 \mathrm{in} .=2.54 \mathrm{~cm})$. 


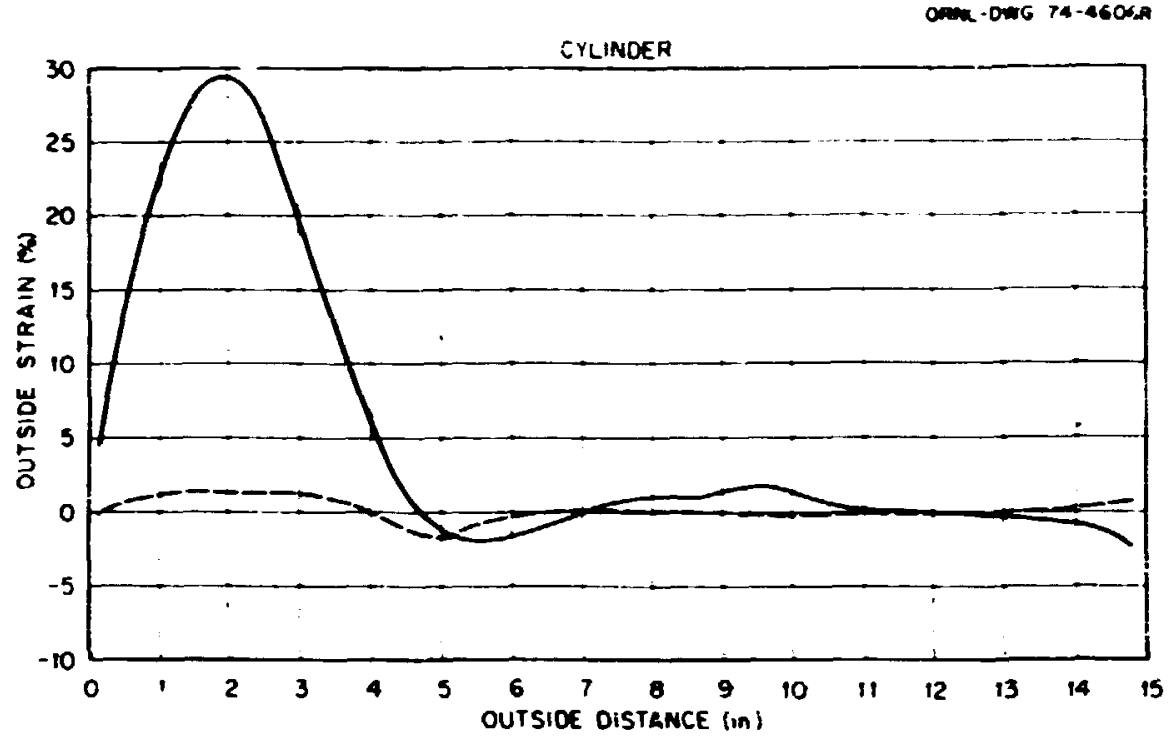

Q5s

WCR SPEC 3A-MI

TEST TIME: $200 \mathrm{hr}$

REFEREACE LINE $120^{\circ}$

LEGEND
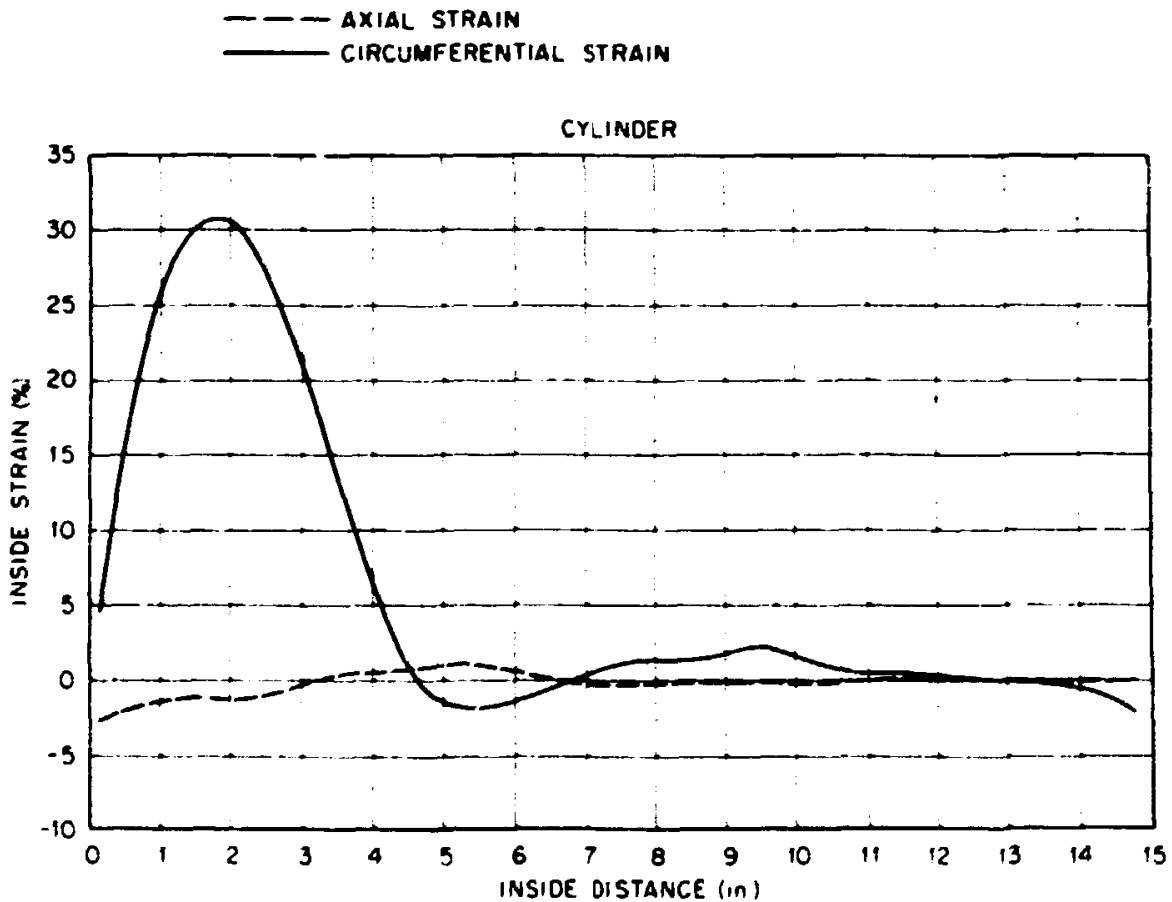

Fig. A5-c. Surface strain distribution for specimen $3 A-M I$ along the axial reference plane, $\theta=120^{\circ}$, at $200 \mathrm{hr}(1 \mathrm{in} .=2.54 \mathrm{~cm})$. 

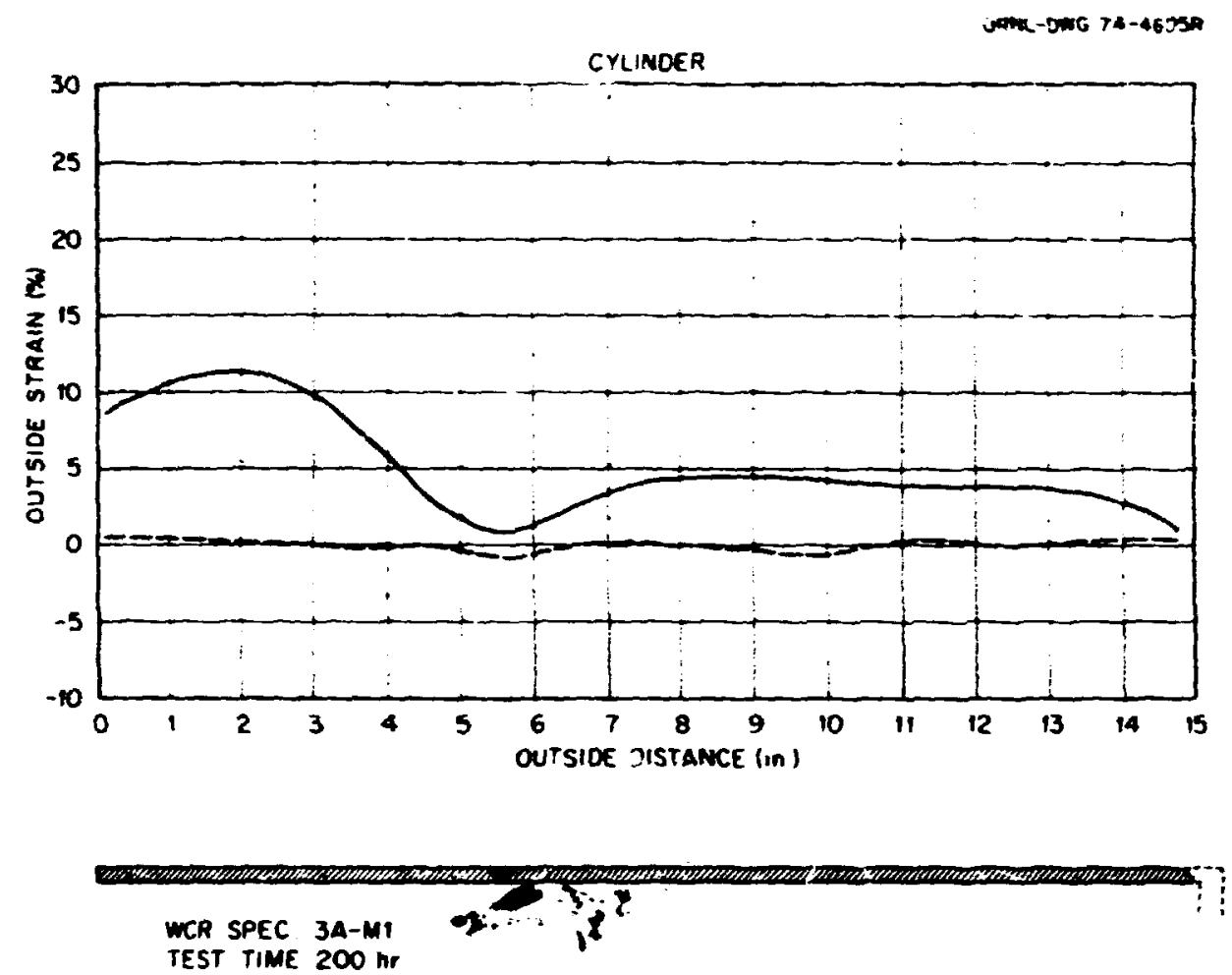

REFERENCE LINE $180^{\circ}$

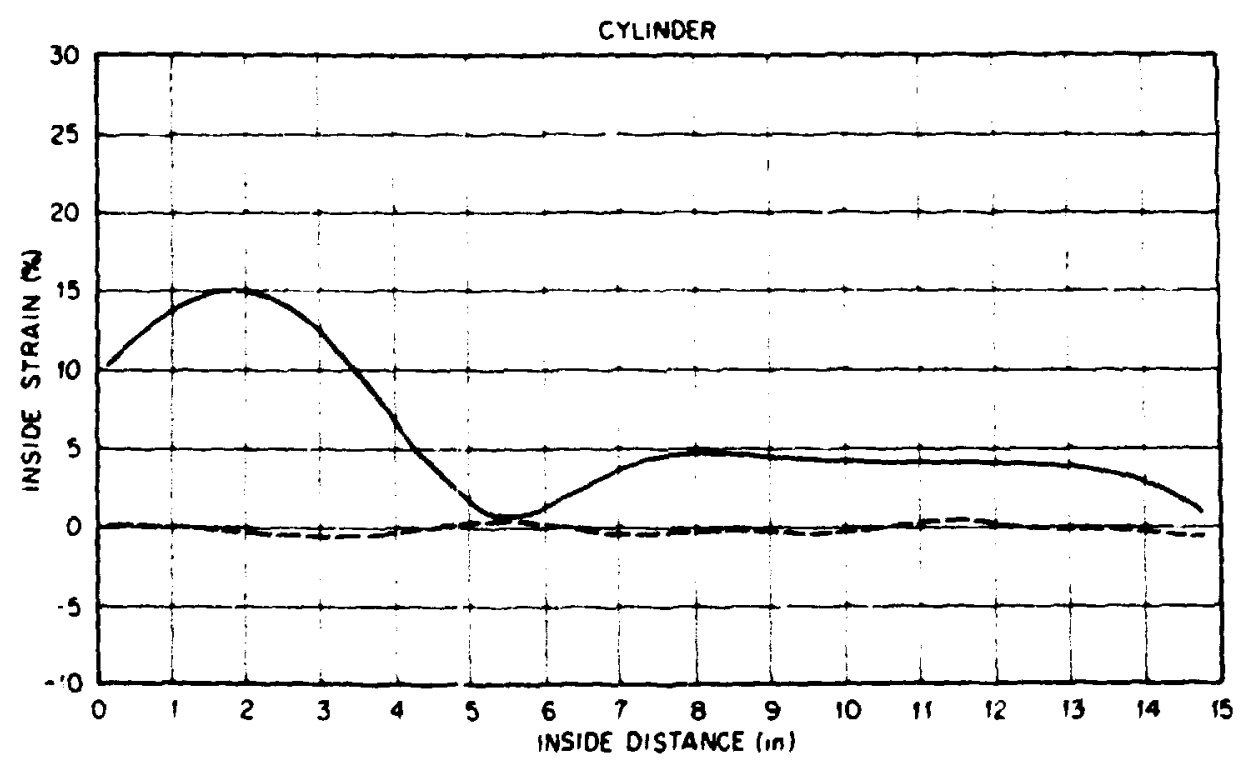

F1g. A5-d. Surface strain distribution for specimen $3 \mathrm{~A}-\mathrm{Ml}$ along the axial reference plane, $\theta=180^{\circ}$, at $200 \mathrm{hr}(1 \mathrm{in} .=2.54 \mathrm{~cm})$. 

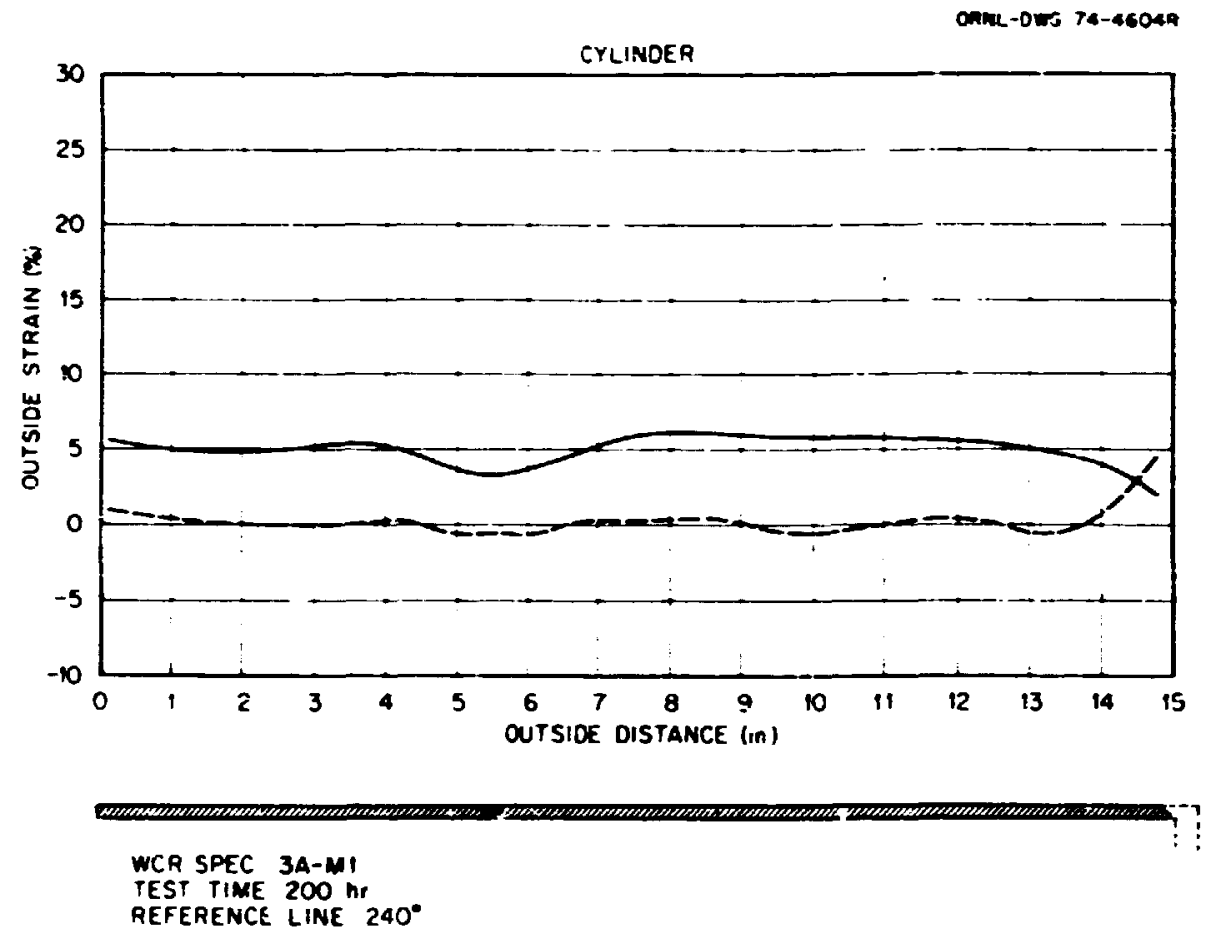

LEGEND

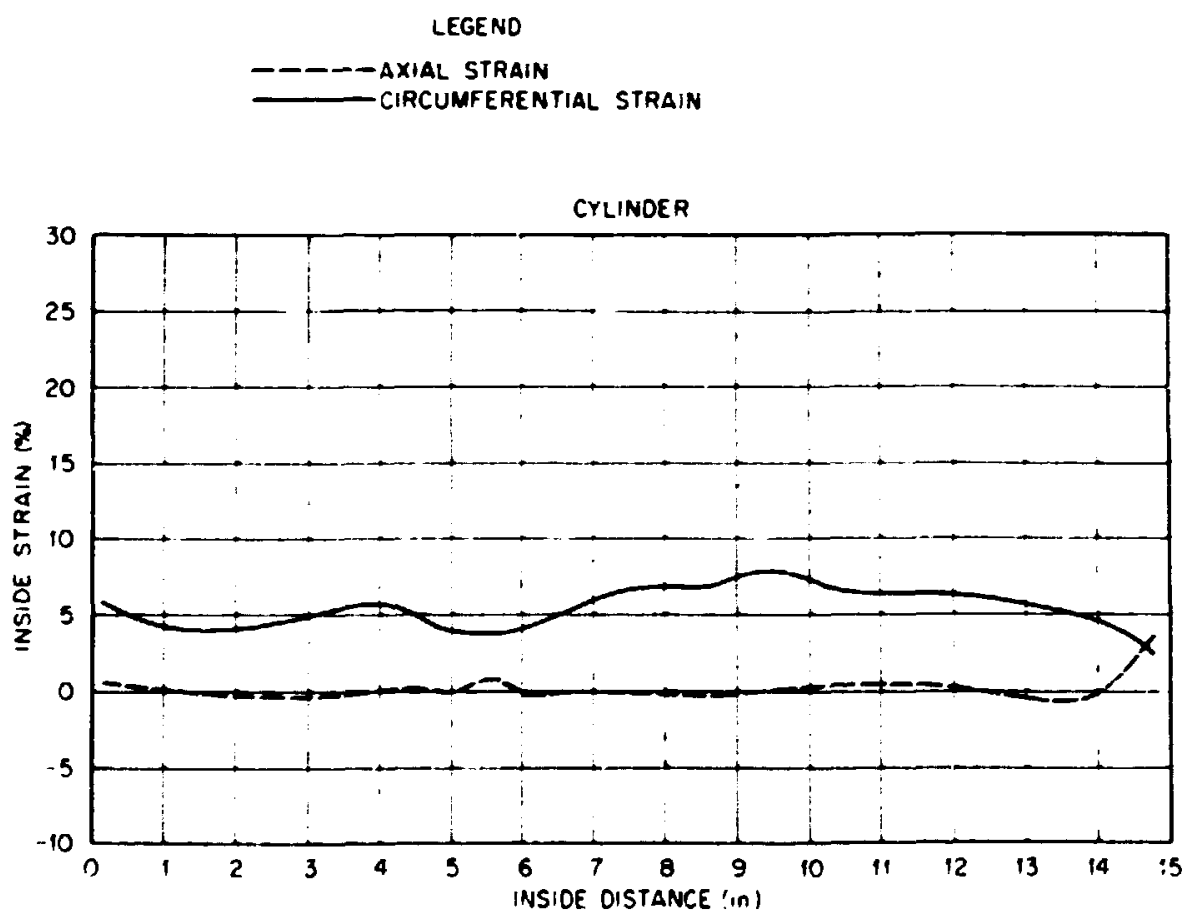

Fig. A5-e. Surface strain distribution for specimen $3 A-M 1$ along the axial reference plane, $\theta=240^{\circ}$, at $200 \mathrm{hr}(1 \mathrm{in} .=2.54 \mathrm{~cm})$. 


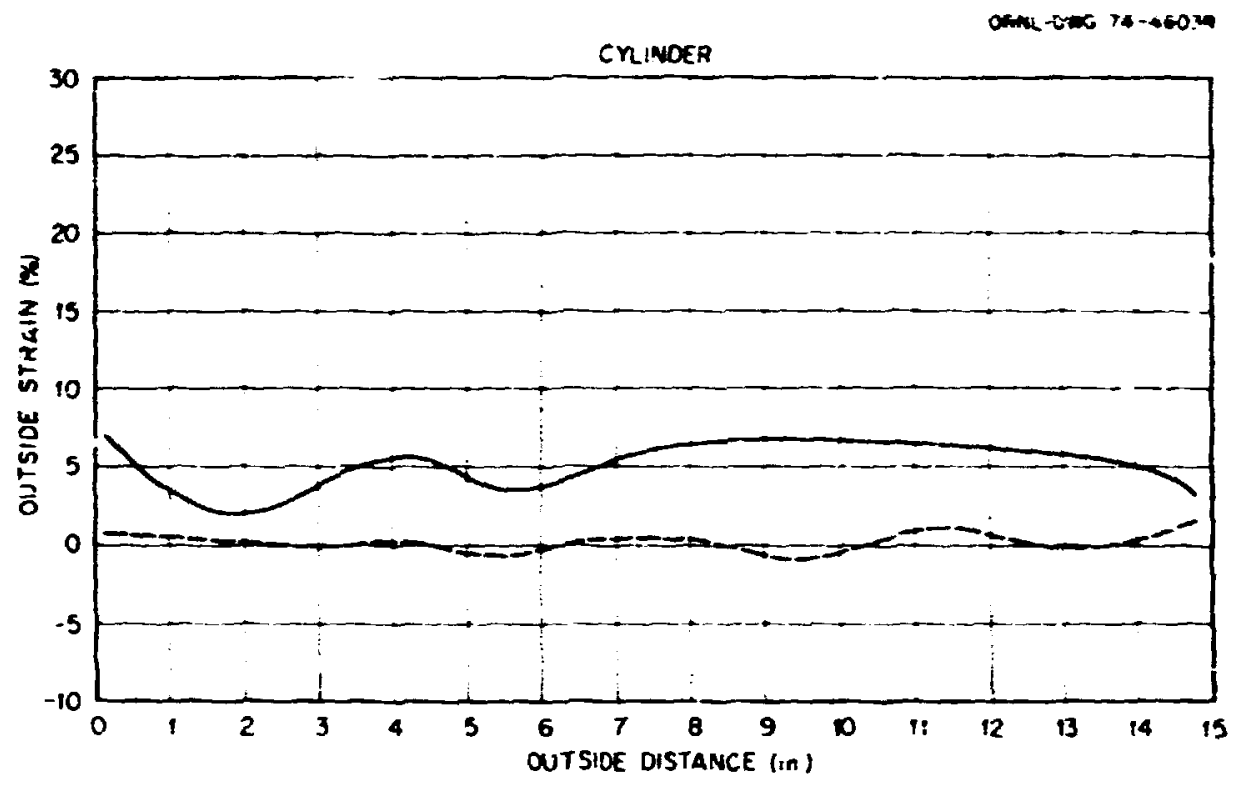

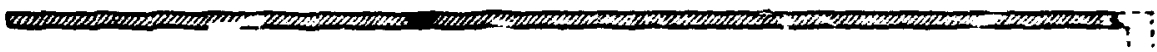

WCR SPEC 3A-MI

TEST TIME: $200 \mathrm{Mr}$

REFERENCE LINE: $300^{\circ}$

LEGEND

AXIAL STRAIN

CIRCUMFERENTIAL STRAIN

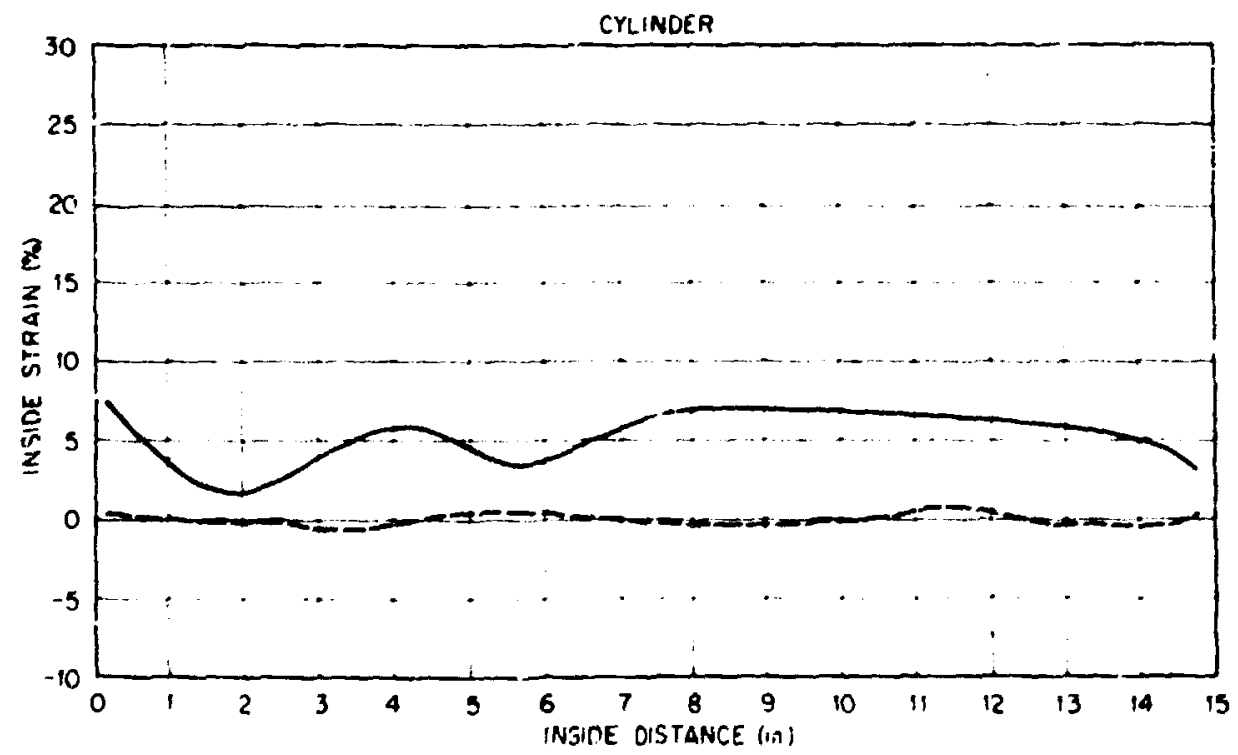

Fig. A5-f. Surface strain distribution for specimen $3 A-M I$ along the axial reference plane, $\theta=300^{\circ}$, at $200 \mathrm{hr}(1 \mathrm{in} .=2.54 \mathrm{~cm})$. 

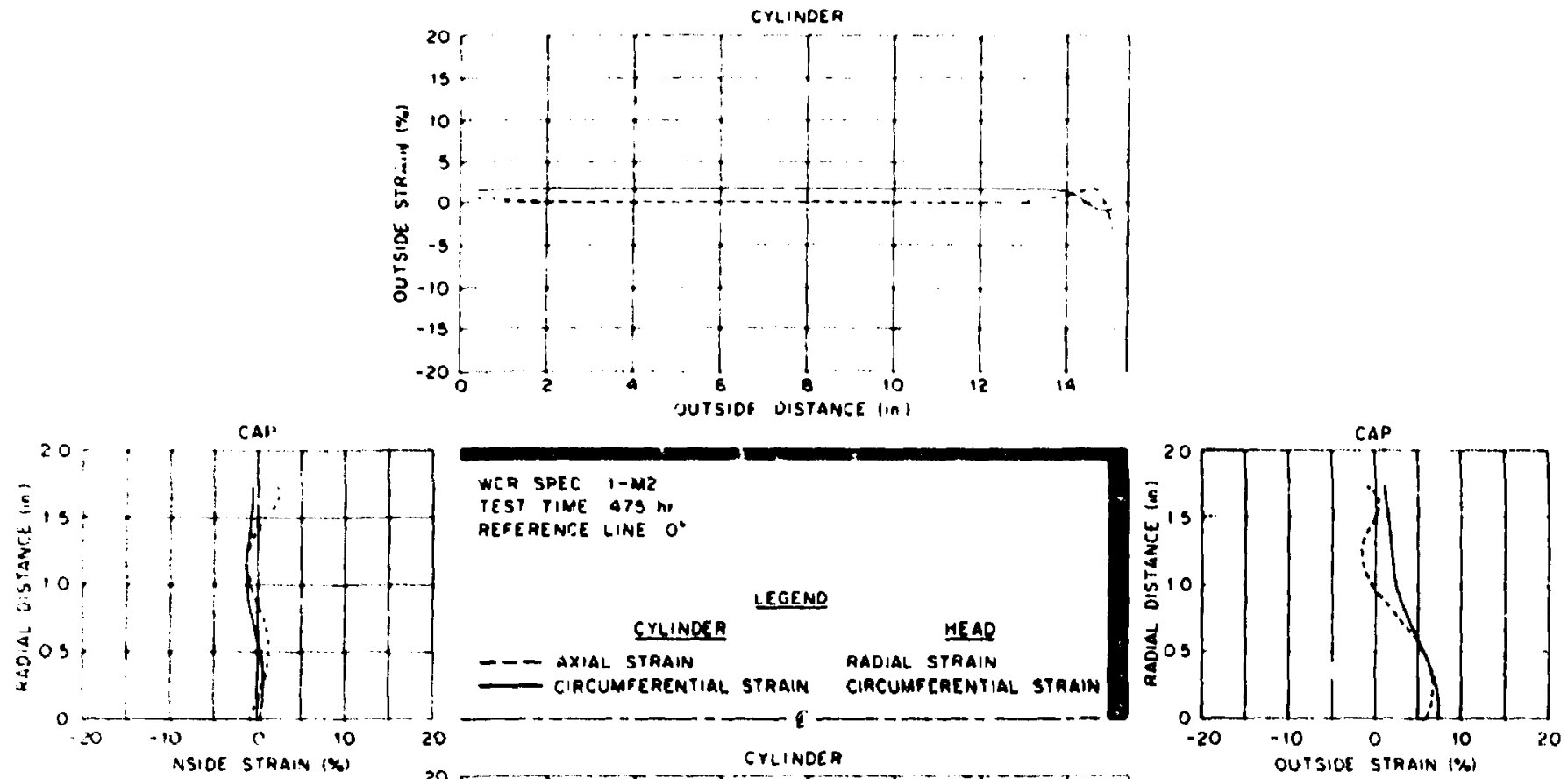

F1g. A6-a. Surface strain distribution for specimen 1-M2 along the axial reference plane, $\theta=0^{\circ}$, at $475 \mathrm{hr}(1 \mathrm{in} .=2.54 \mathrm{~cm})$. 


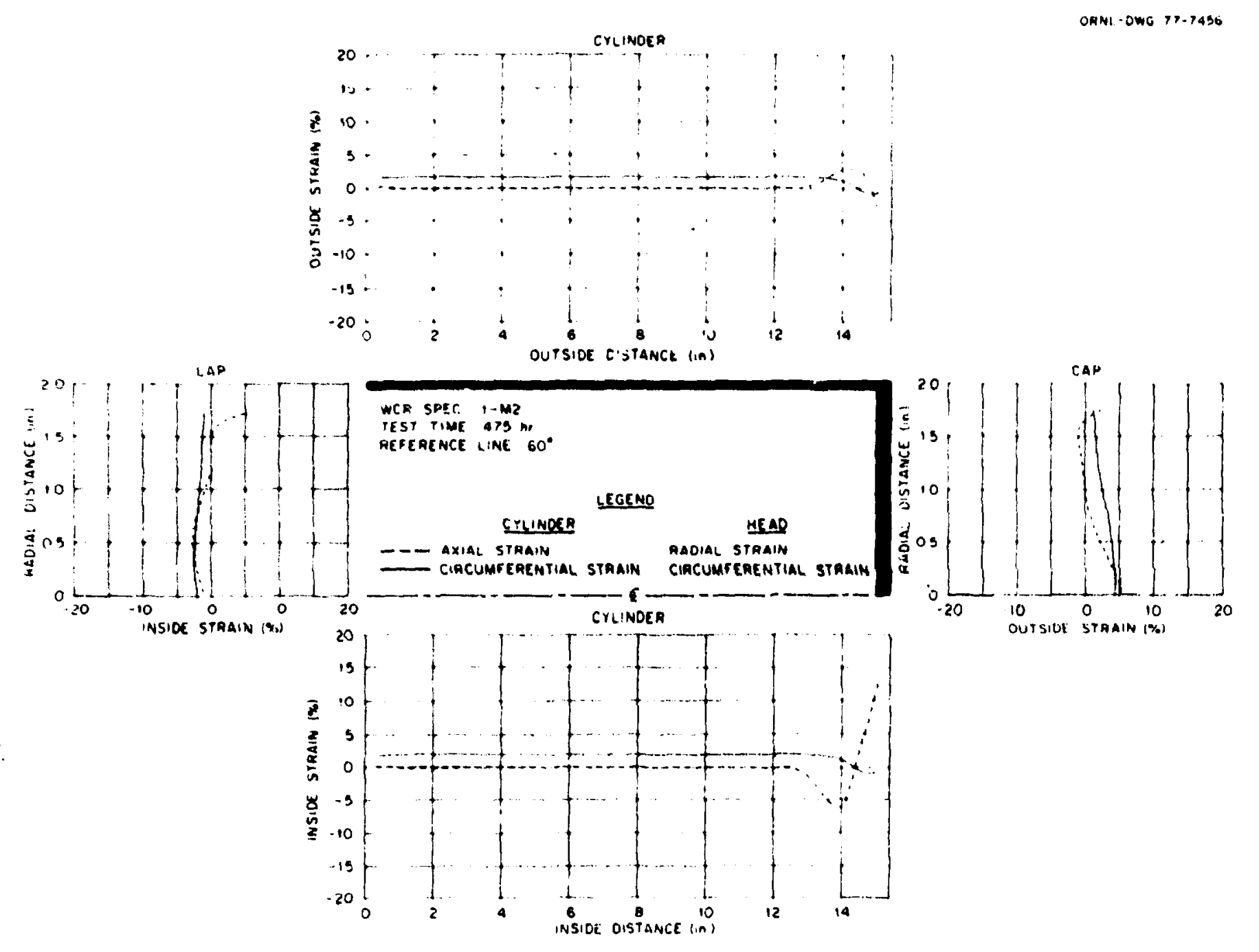

Flg. A6-b. Surface strain distribution for specimen 1-M2 along the axial reference plane, $\theta=60^{\circ}$, at $475 \mathrm{hr}(1 \mathrm{in} .=2.54 \mathrm{~cm})$. 


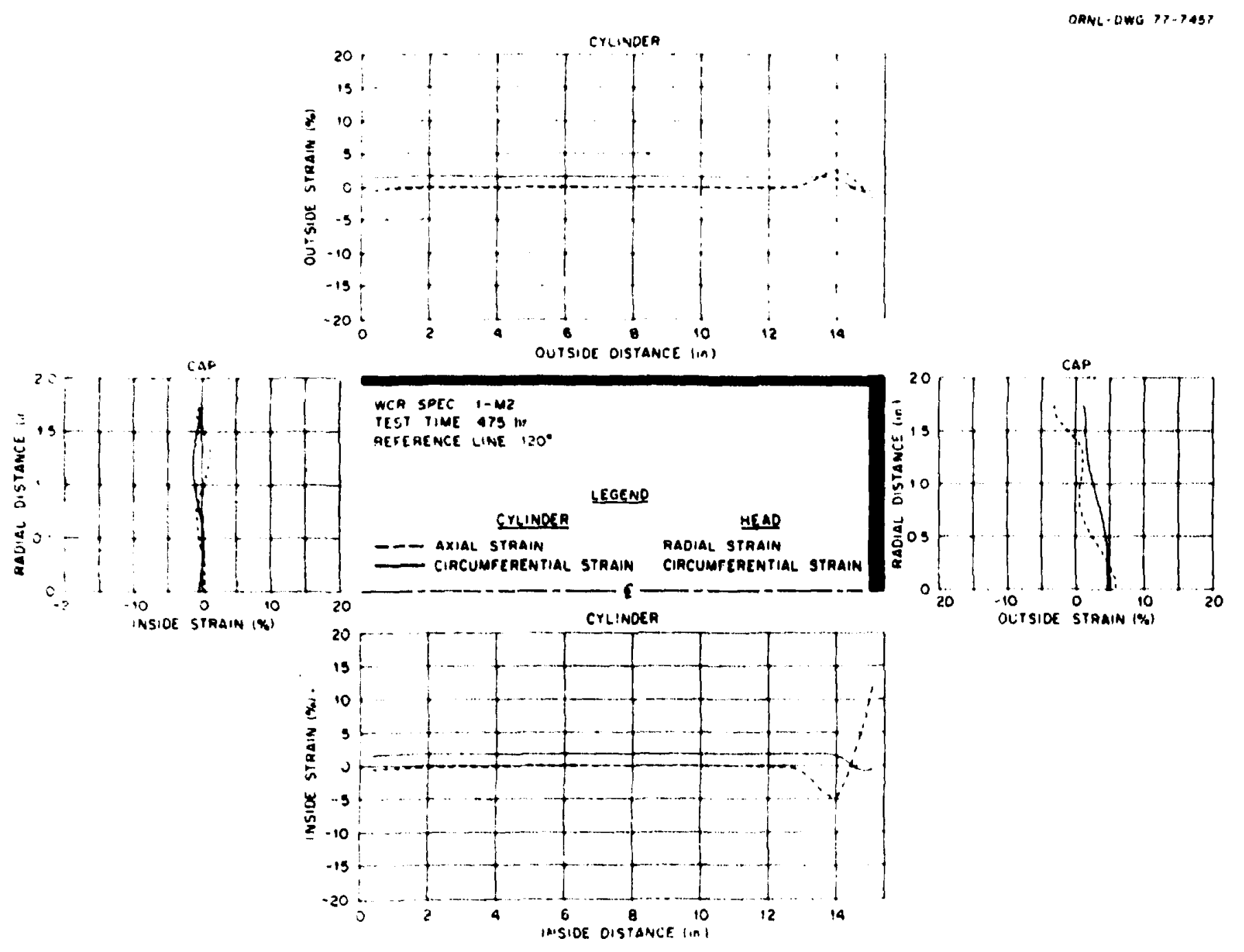

F1g. A6-c. Suriace strain distribution for specimen 1-M2 along the axial reference plane, $\theta=120^{\circ}$, at $475 \mathrm{hr}(1 \mathrm{ln} .=2.54 \mathrm{~cm})$. 


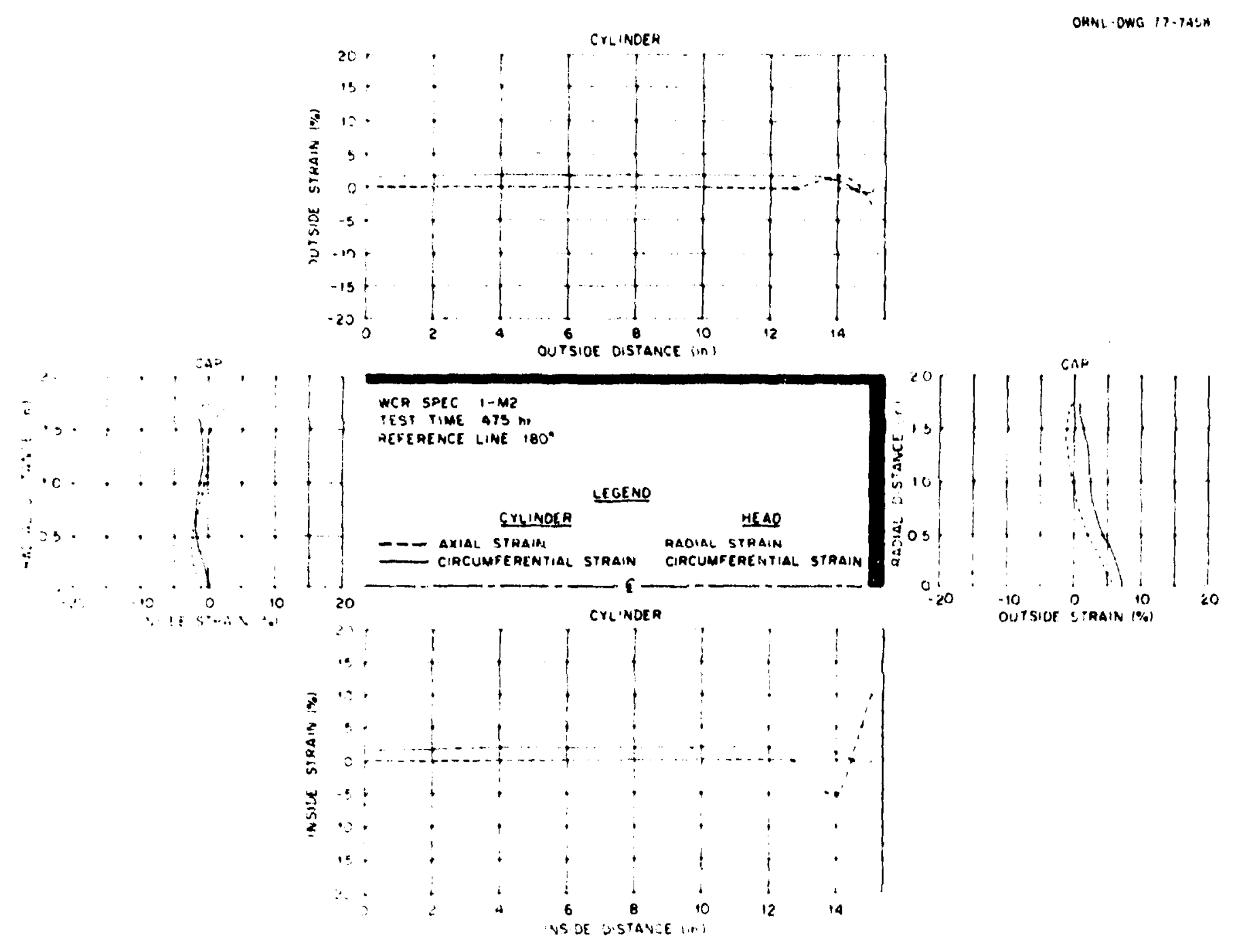

Fig. A6-d. Surface strain distribution for specimen 1-M2 along the axial reference plane, $\theta=180^{\circ}$, at $475 \mathrm{hr}(2 \mathrm{in} .=2.54 \mathrm{~cm})$. 

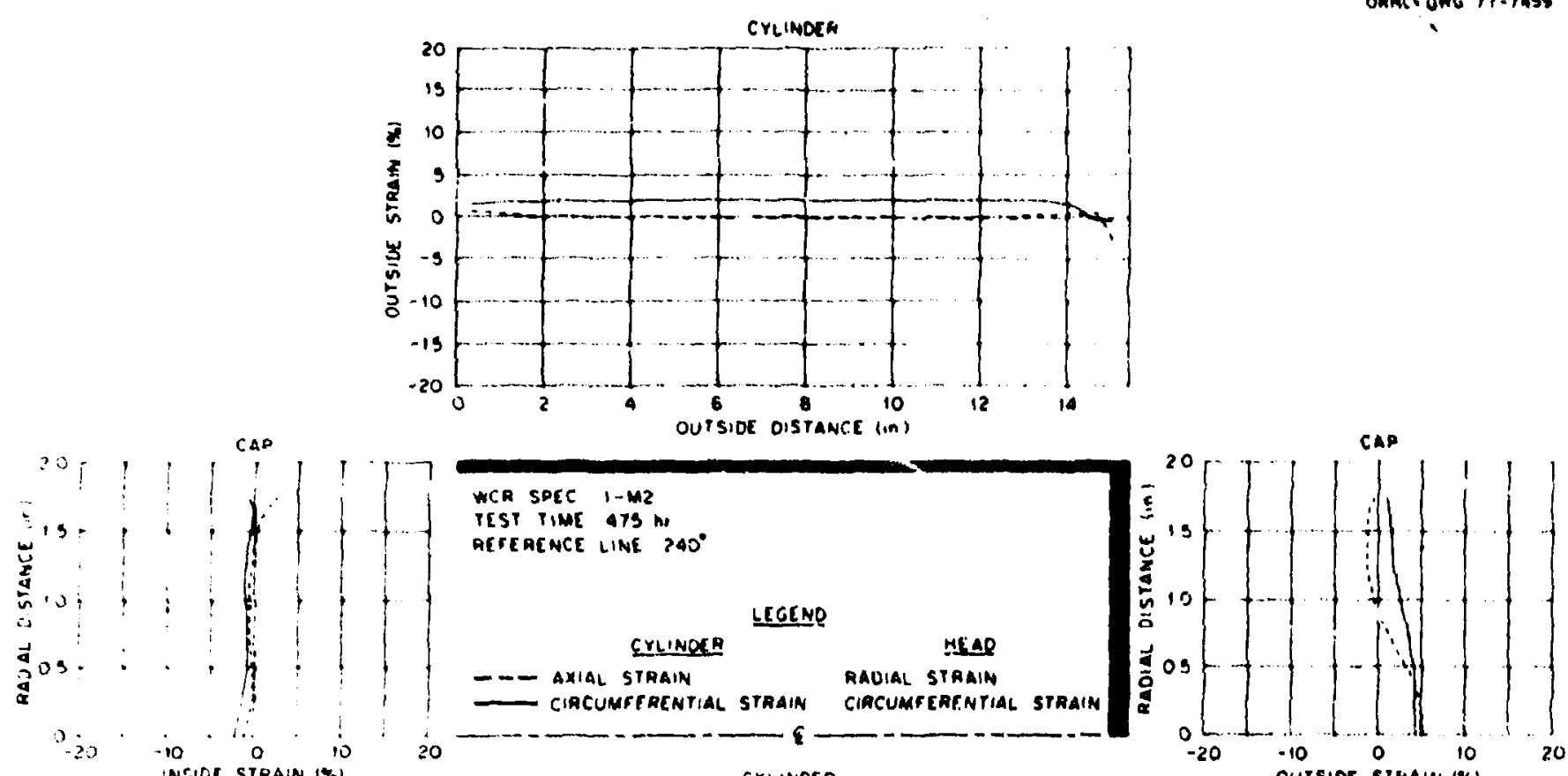

Fig. A6-e. Surface strain alstribution for specimen 1-M2 along the axial reference plane, $\theta=240^{\circ}$, at $475 \mathrm{hr}(1 \mathrm{ln} .=2.54 \mathrm{~cm})$. 


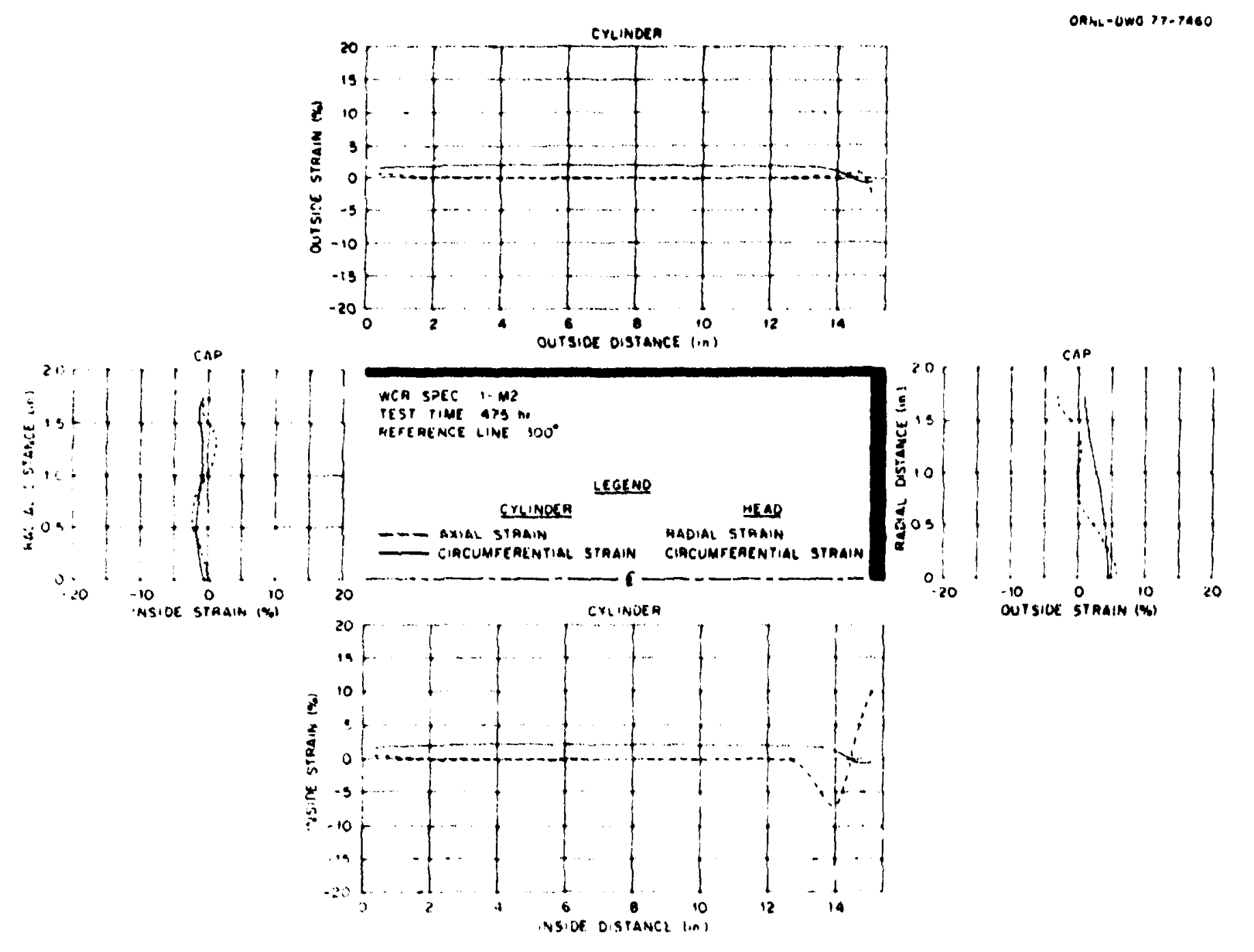

F1B. A6-1. Surface strain distribution for specimen 1-ME along the axtal reference plane, $\theta=300^{\circ}$, at $475 \mathrm{hr}(1 \mathrm{ln} ., 2.54 \mathrm{~cm})$. 


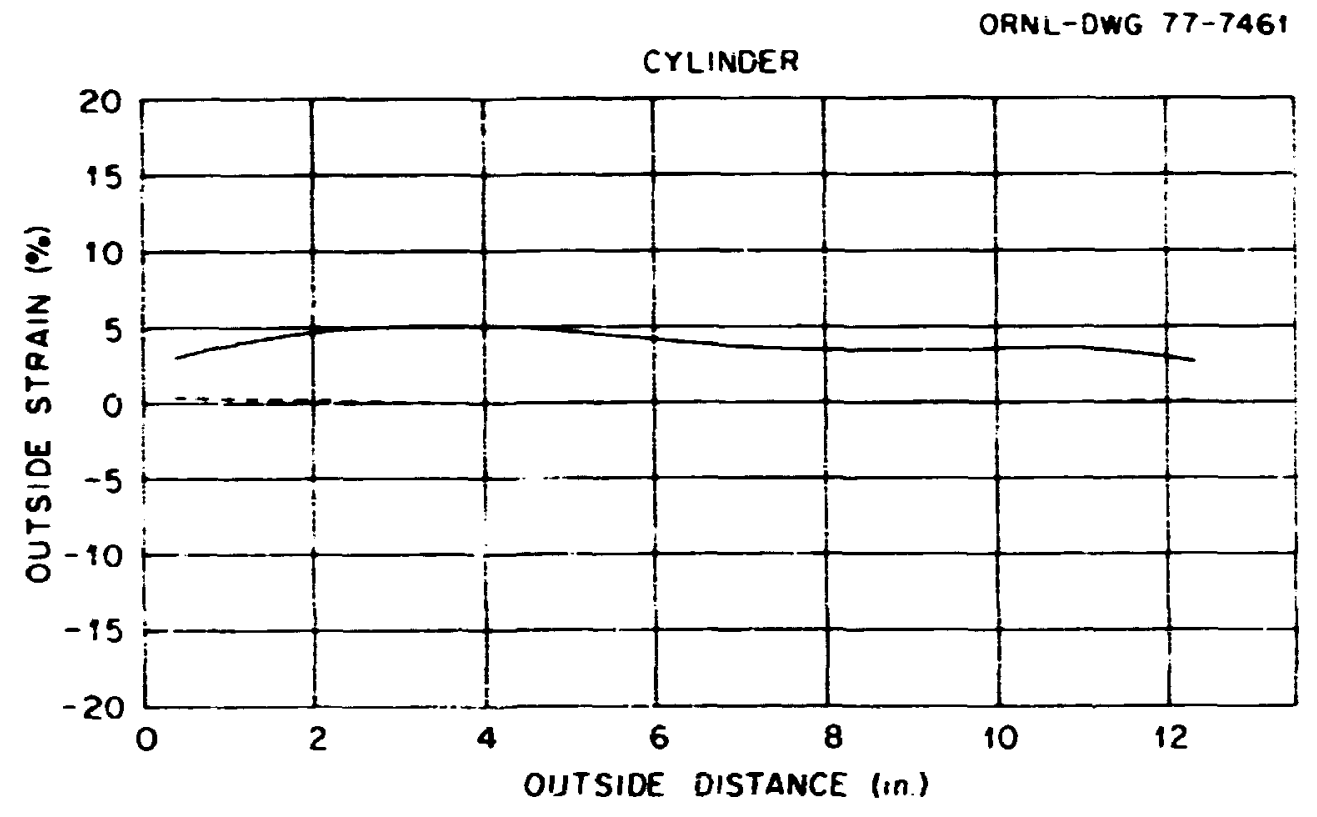

WCR SPEC: $14-M 2$

TEST TIME: $3576 \mathrm{hr}$

REFERENCE LINE: $0^{*}$

LEGEND

- - AXIAL STRAIN

CIRCUMFERENTIAL STRAIN

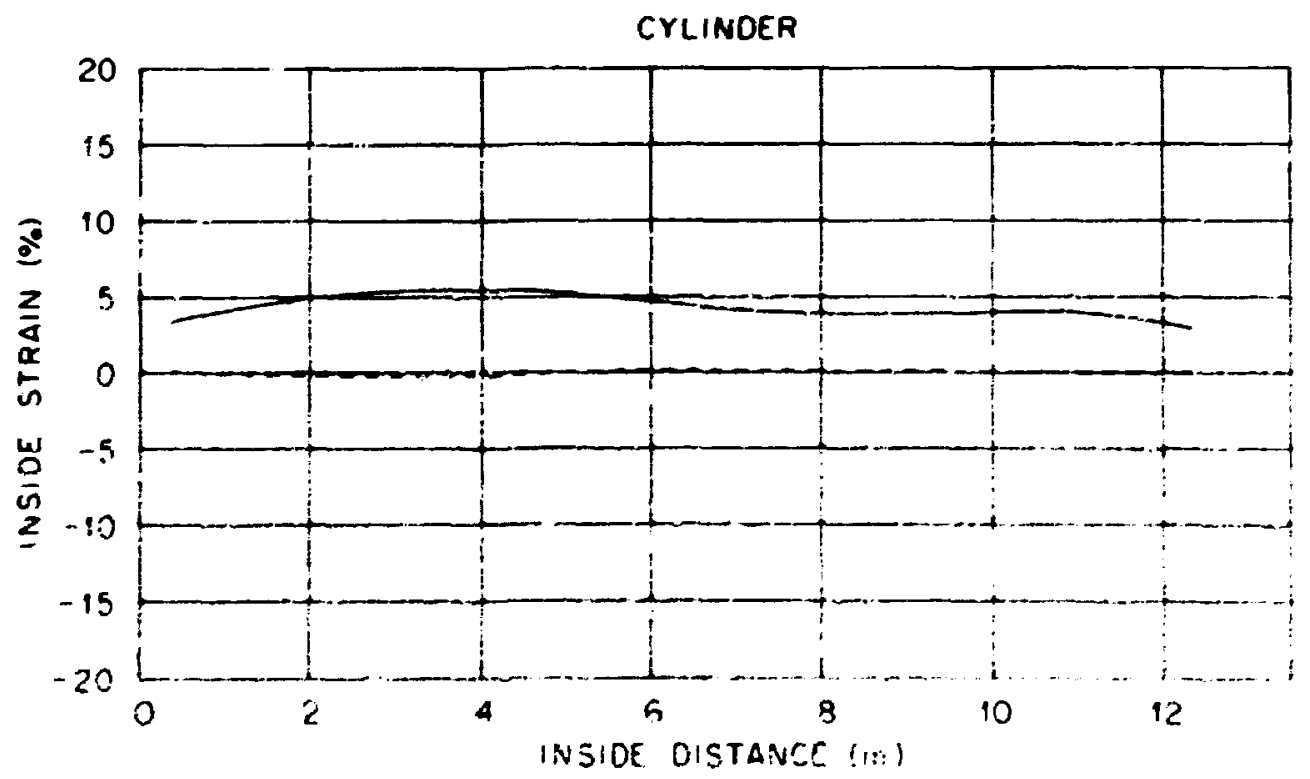

18. A7-a. Surface atrain distribution for spesinen 1A-K2 along the axial reference plane, $A=0^{\circ}$, t $3576 \mathrm{hr}(1 \mathrm{in} .=2.54 \mathrm{~cm}$ ). 
ORNL-DWG 77-7462

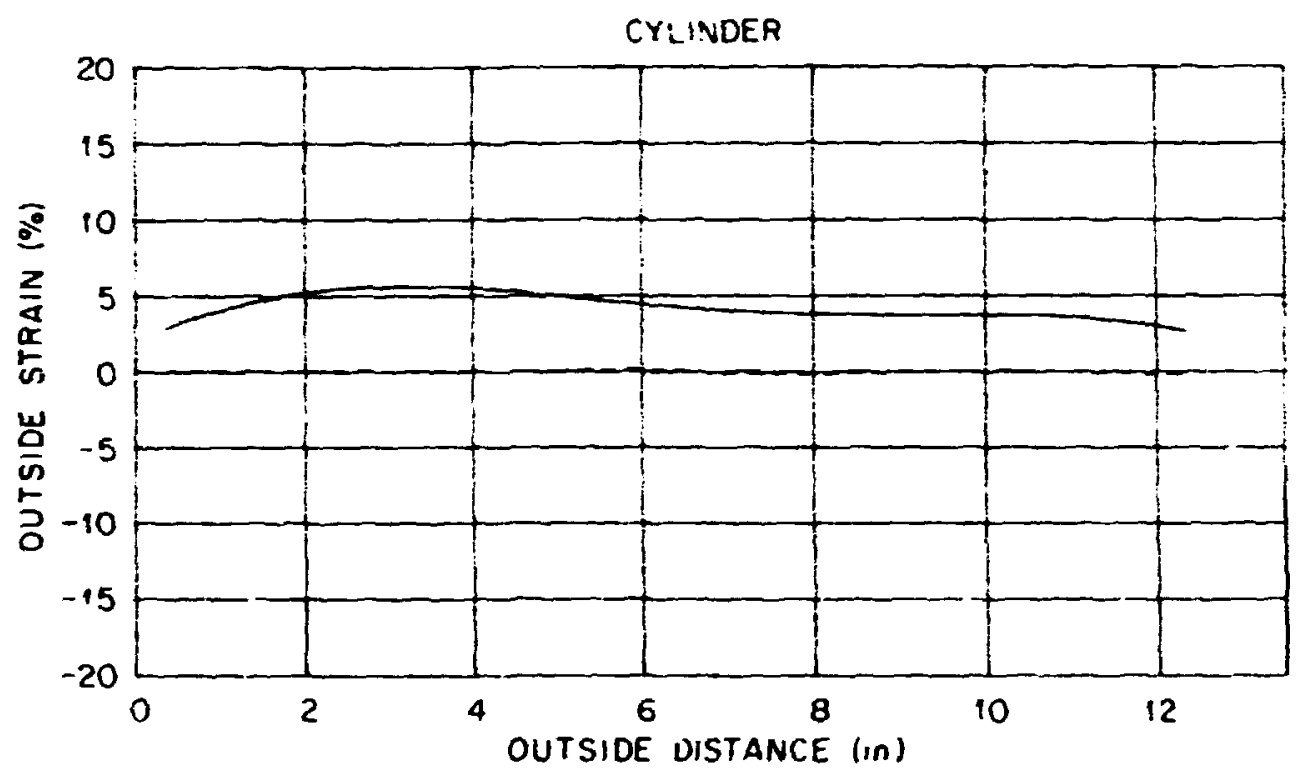

WCR SPEC :A-M2

TEST TIME: $3576 \mathrm{hr}$

REFERENCE LINE: $60^{\circ}$

\section{I.EGENC}

- - - AXIAL STRAIN

- CIRCUMFEREMTIAL STRAIN

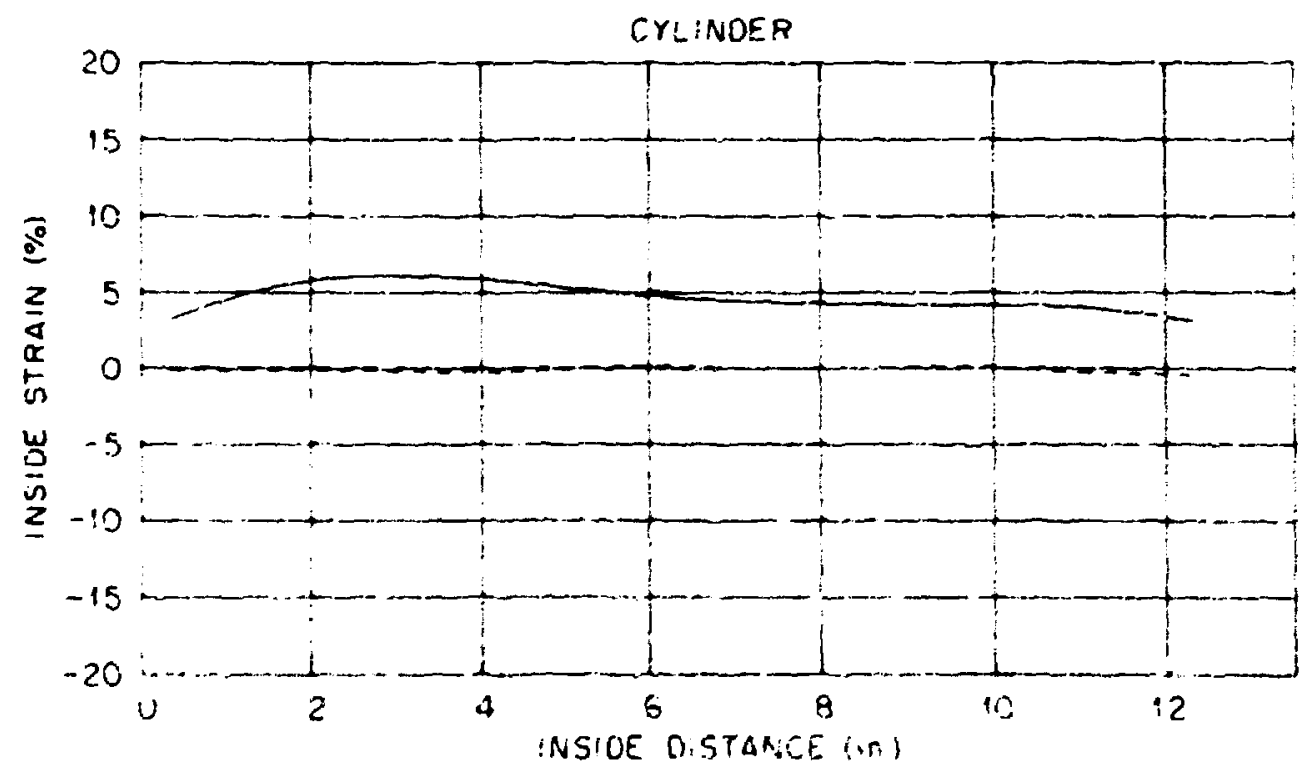

Pig. A7-b. Skince strain distribution ror sps:amen IA-M2 along the asial roference plare, $\theta=60^{\circ}$, at $3576 \mathrm{hr}(2 \mathrm{in} .-2.54 \mathrm{~cm}$ ). 
CYLINDER

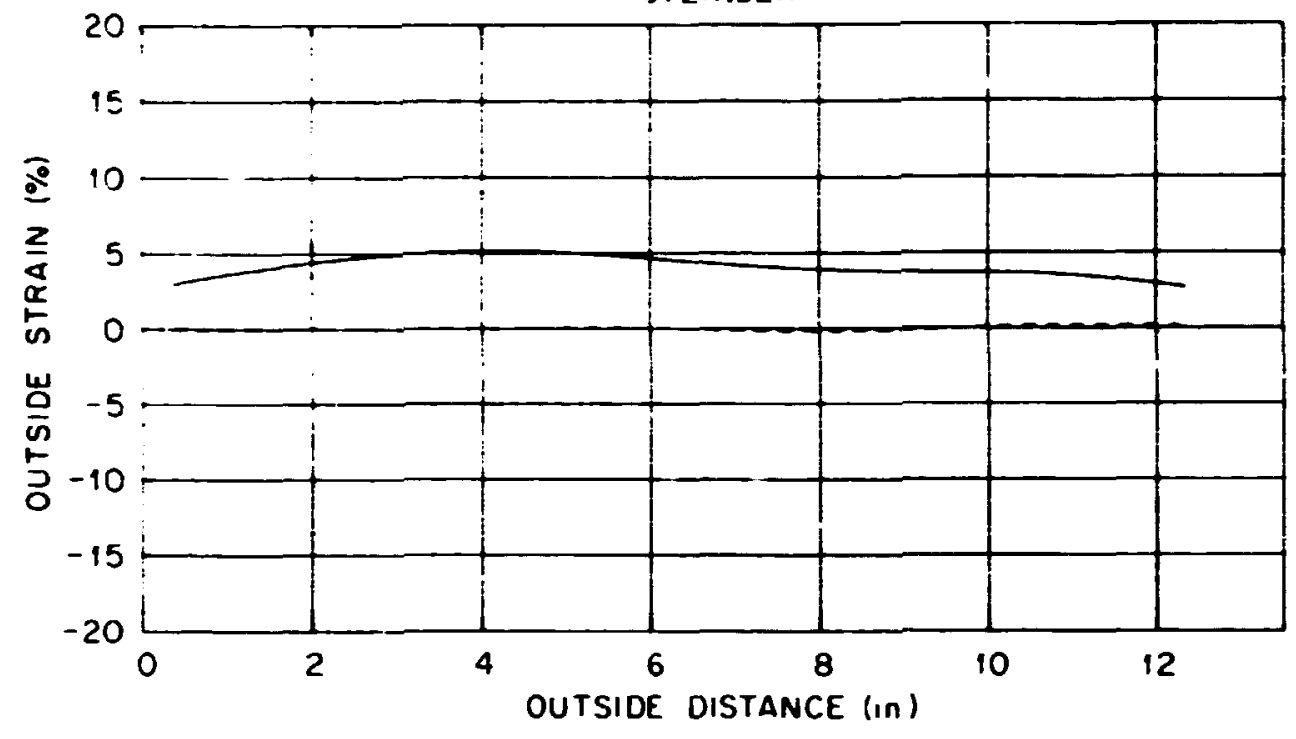

WCR SPEC.: 1A-M2

TEST TIME: $3576 \mathrm{hr}$

REFERENCE LINE: $120^{\circ}$

\section{LEGEND}

- - AXIAL STRAIN

CIRCUMFERENTIAL STRAIN

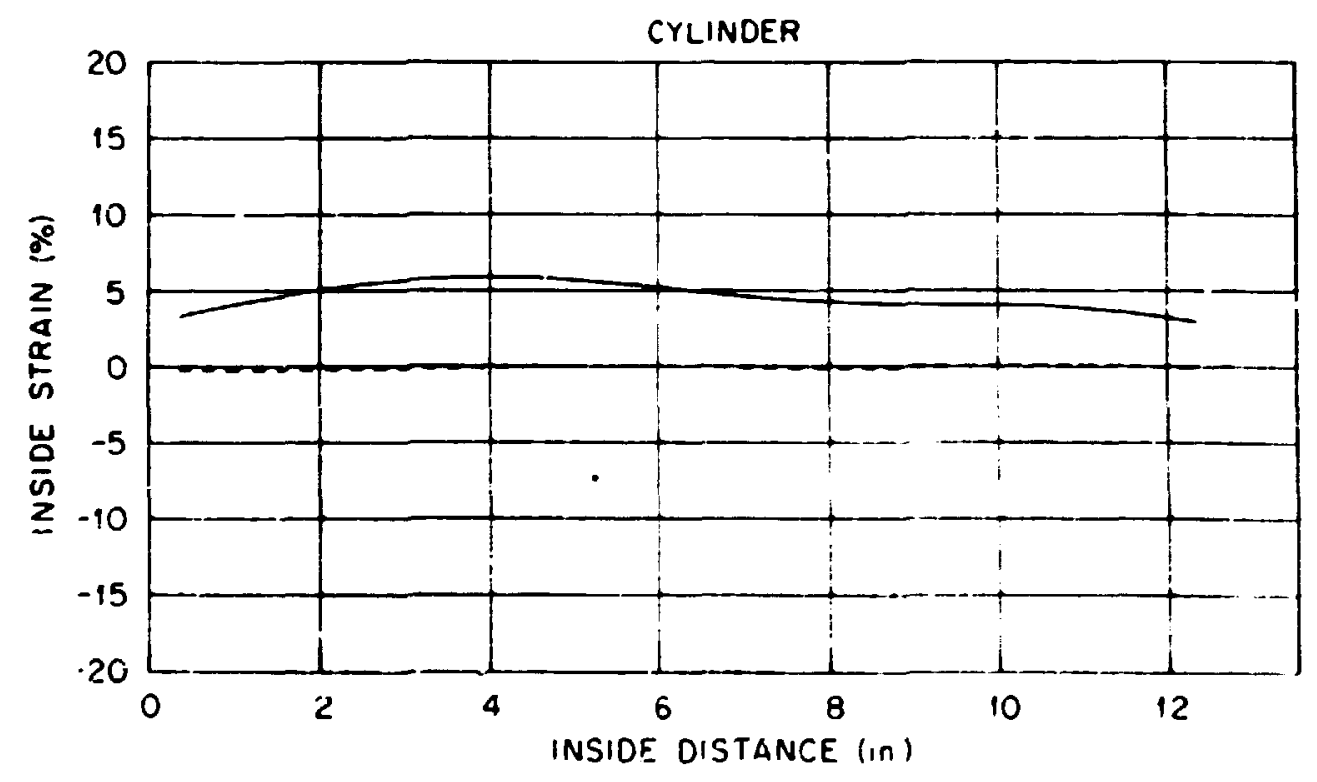

Pig. A7-c. Surface strein distribution for specimen IA-M2 along the axial reference plane, $\theta=120^{\circ}$, at $3576 \mathrm{hr}(1 \mathrm{in},=2.54 \mathrm{~cm})$. 

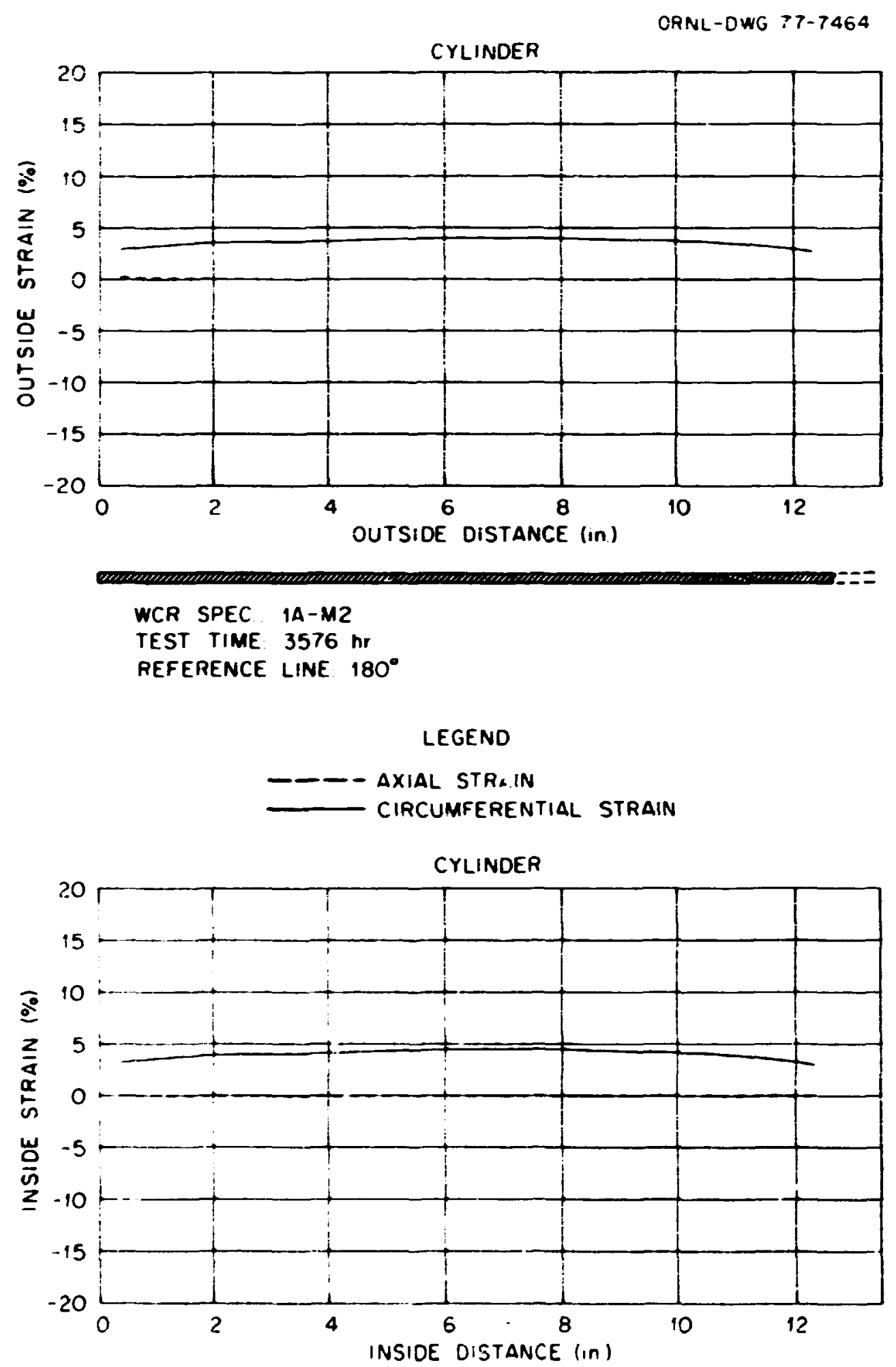

Fig. A7-d. Surface strain distribution for specimen 2A-112 along the axial reference plane, $\theta=180^{\circ}$, at $3576 \mathrm{hr}\left(1 \mathrm{In}\right.$. $\left.=2.5 \circ^{\circ} \mathrm{cm}\right)$. 


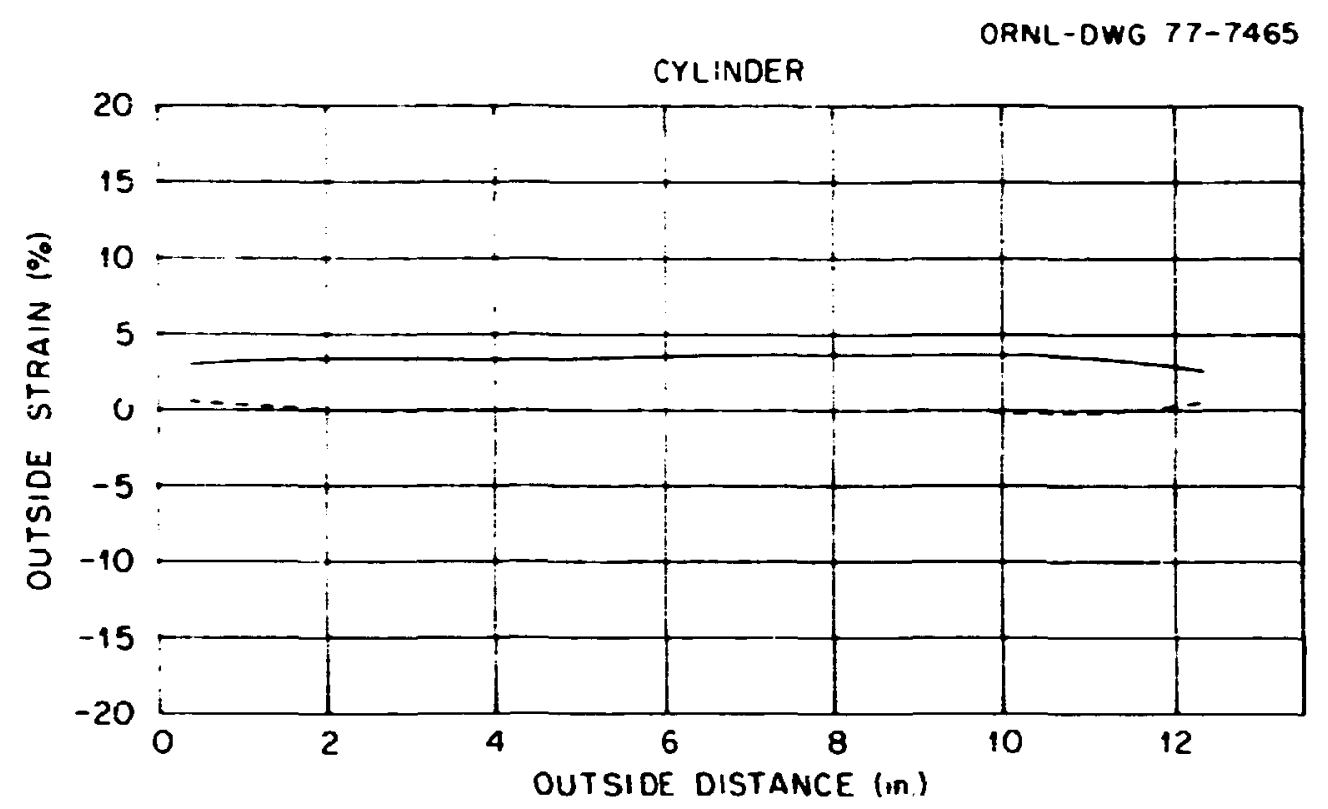

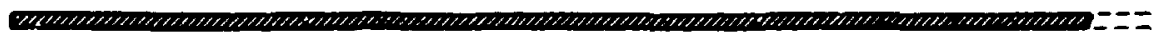

WCR SPEC: $14-M 2$

TEST TIME: $3576 \mathrm{hr}$

REFERENCE LINE: $240^{\circ}$

LEGEND

- - AXIAL STRAIN

CIRCUMFERENTIAL STRAIN

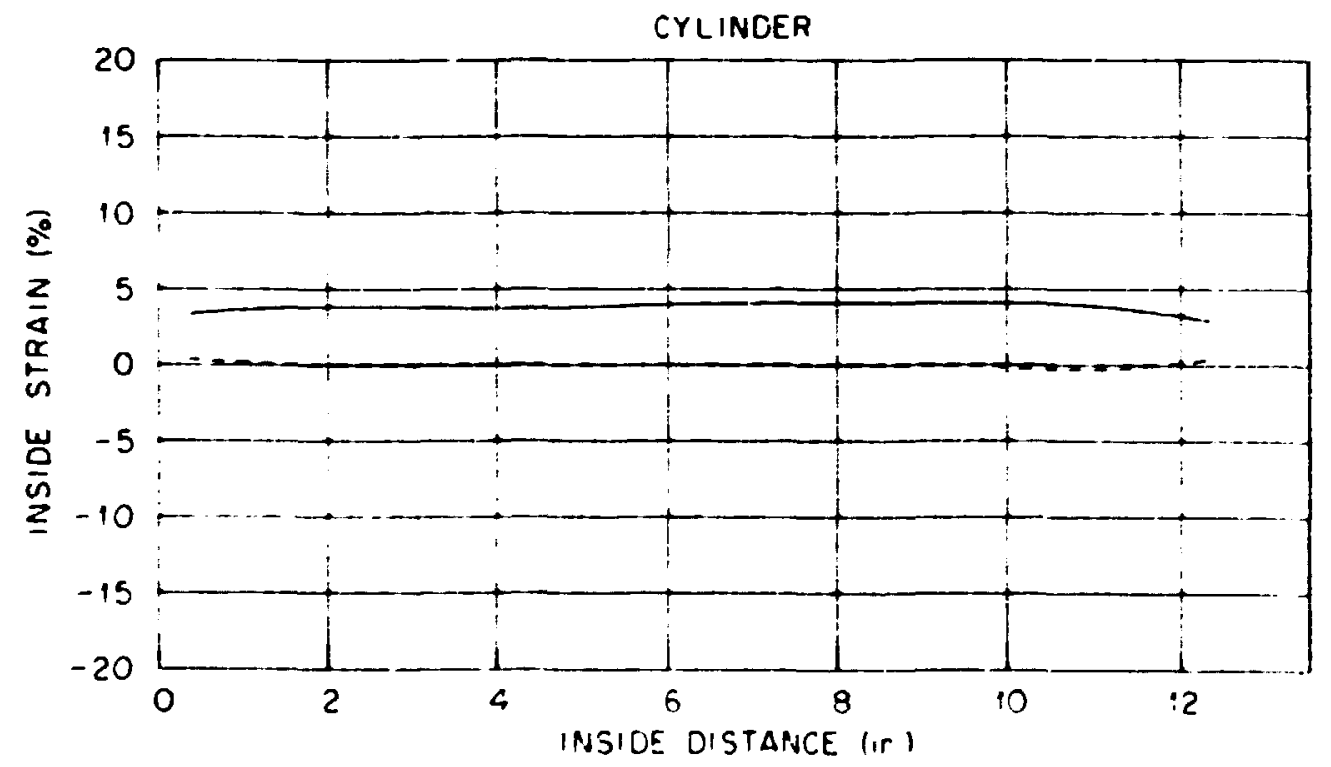

Fig. A7-e. Surface strain distribution for specimen $2 A-K 2$ along the axial reference plane, $\theta=240^{\circ}$, at $35^{\prime} / 6 \mathrm{hr}(1 \mathrm{in} .=2.54 \mathrm{~cm})$. 


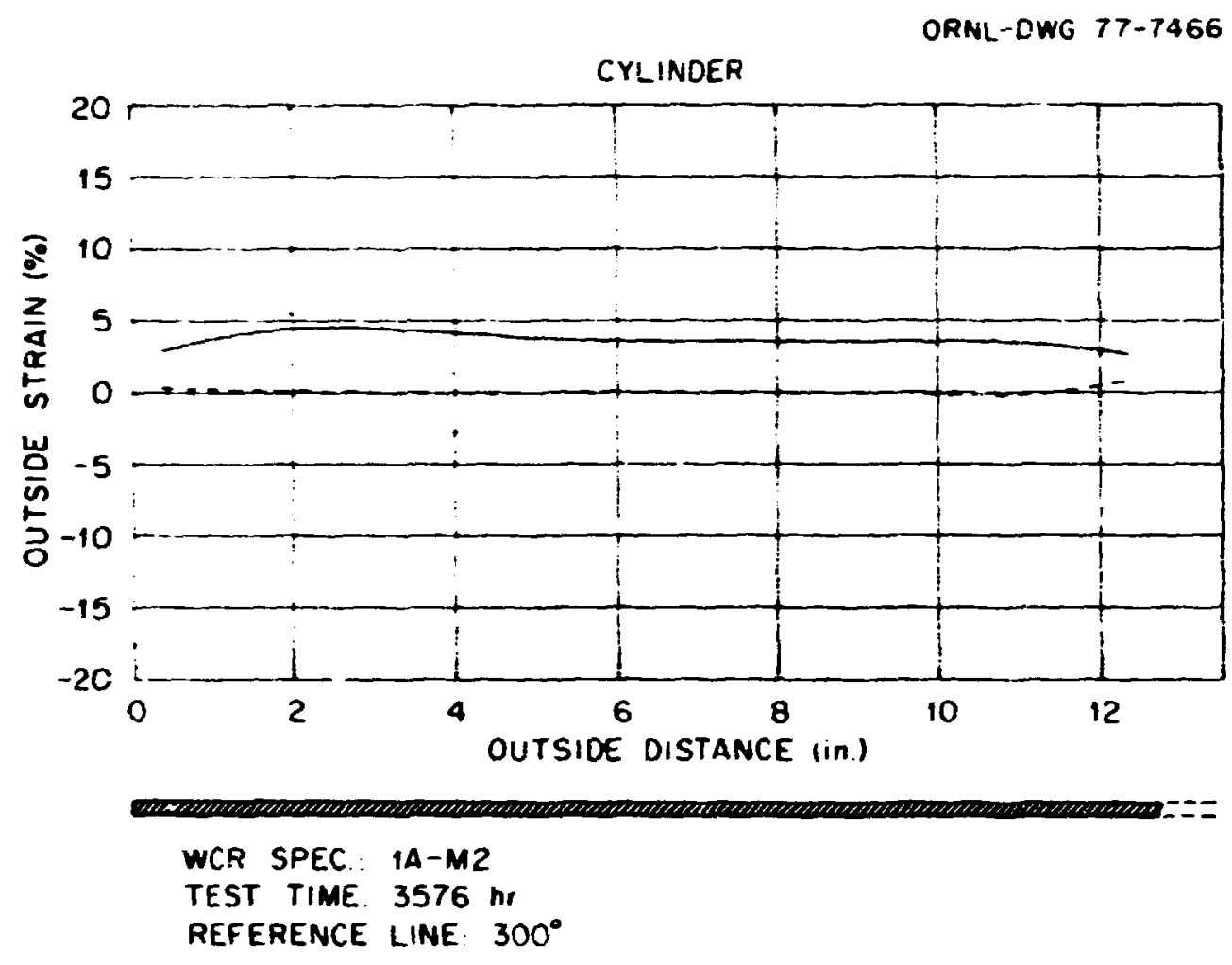

LEGEND
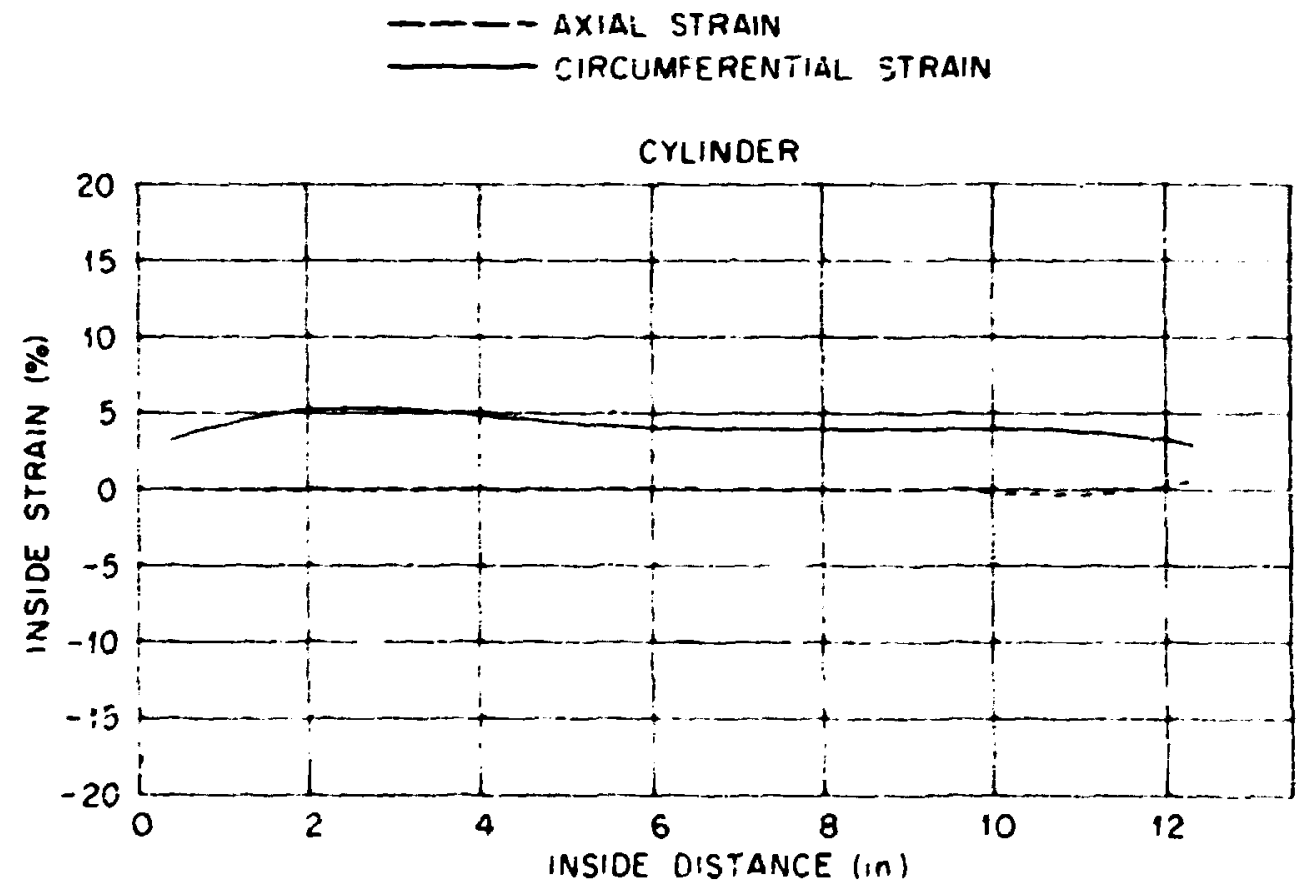

- A7-f. Surface strain distributior for specimen $1 A-12$ along the axdal .ererence plane, $\theta=300^{\circ}$, at $3576 \mathrm{hr}(1 \mathrm{in} .=2.54 \mathrm{~cm})$. 


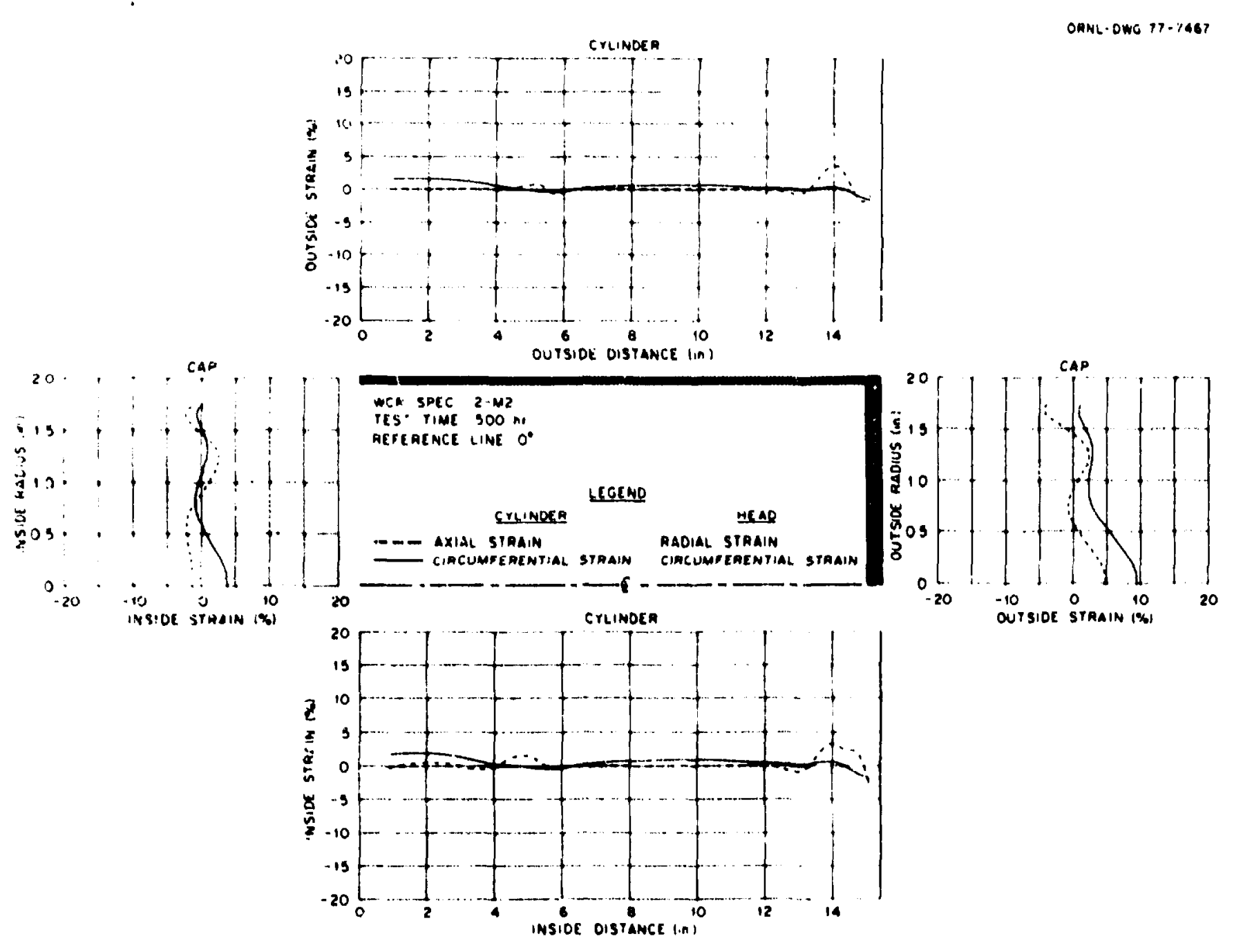

Fig. A8-a, Surface utrain distribution for specimen 2-M2 along the axial reference plane, $\theta=0^{\circ}$, at $500 \mathrm{hr}(1 \mathrm{ln},=2.54 \mathrm{~cm})$. 

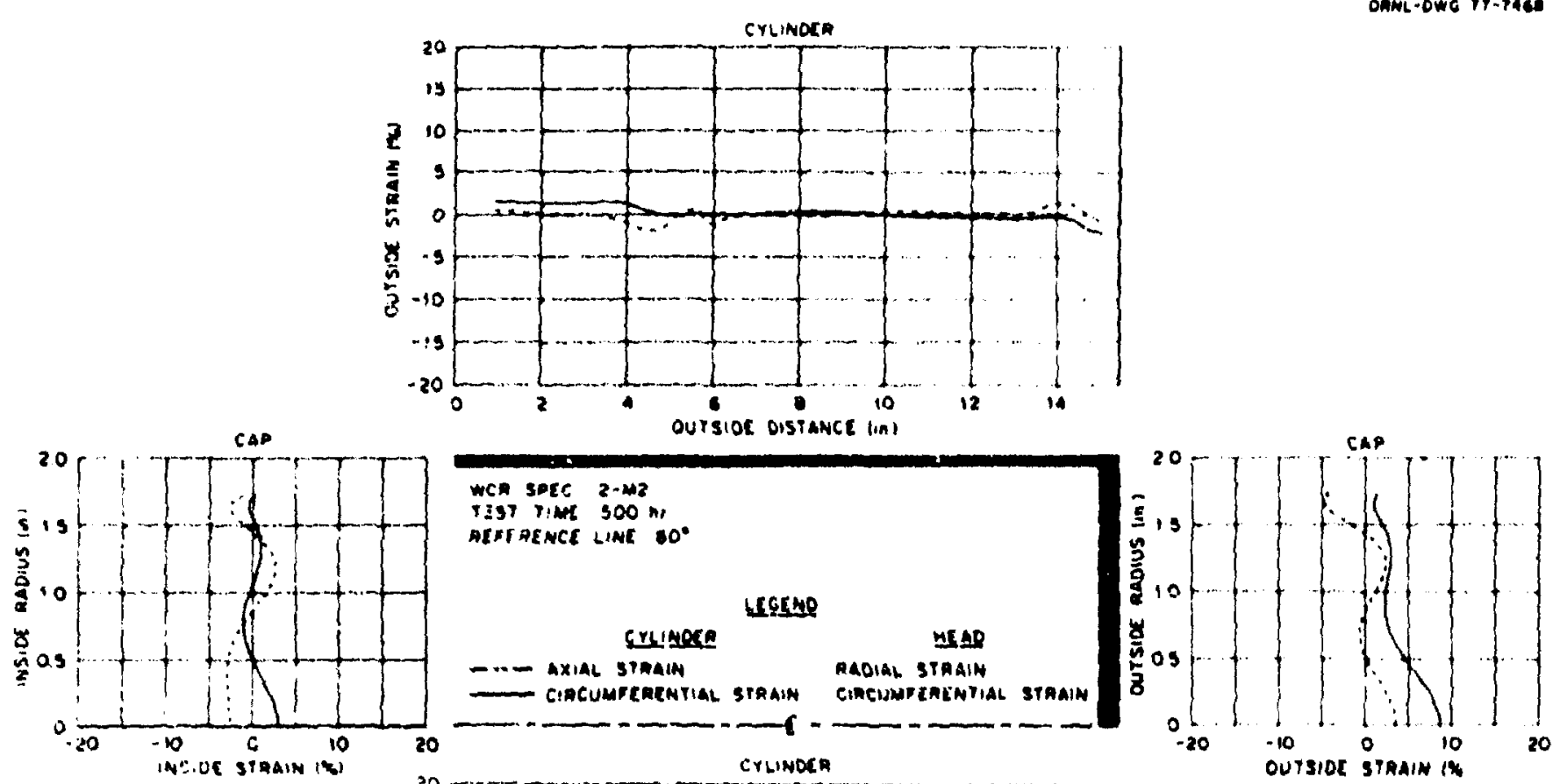

Fig. A8-b. Surtace strain aistribution for specimen 2-Me along the axtal reference piane, $\theta=60^{\circ}$, at $500 \mathrm{hr}$ (1 in. $=2.54 \mathrm{~cm}$ ). 

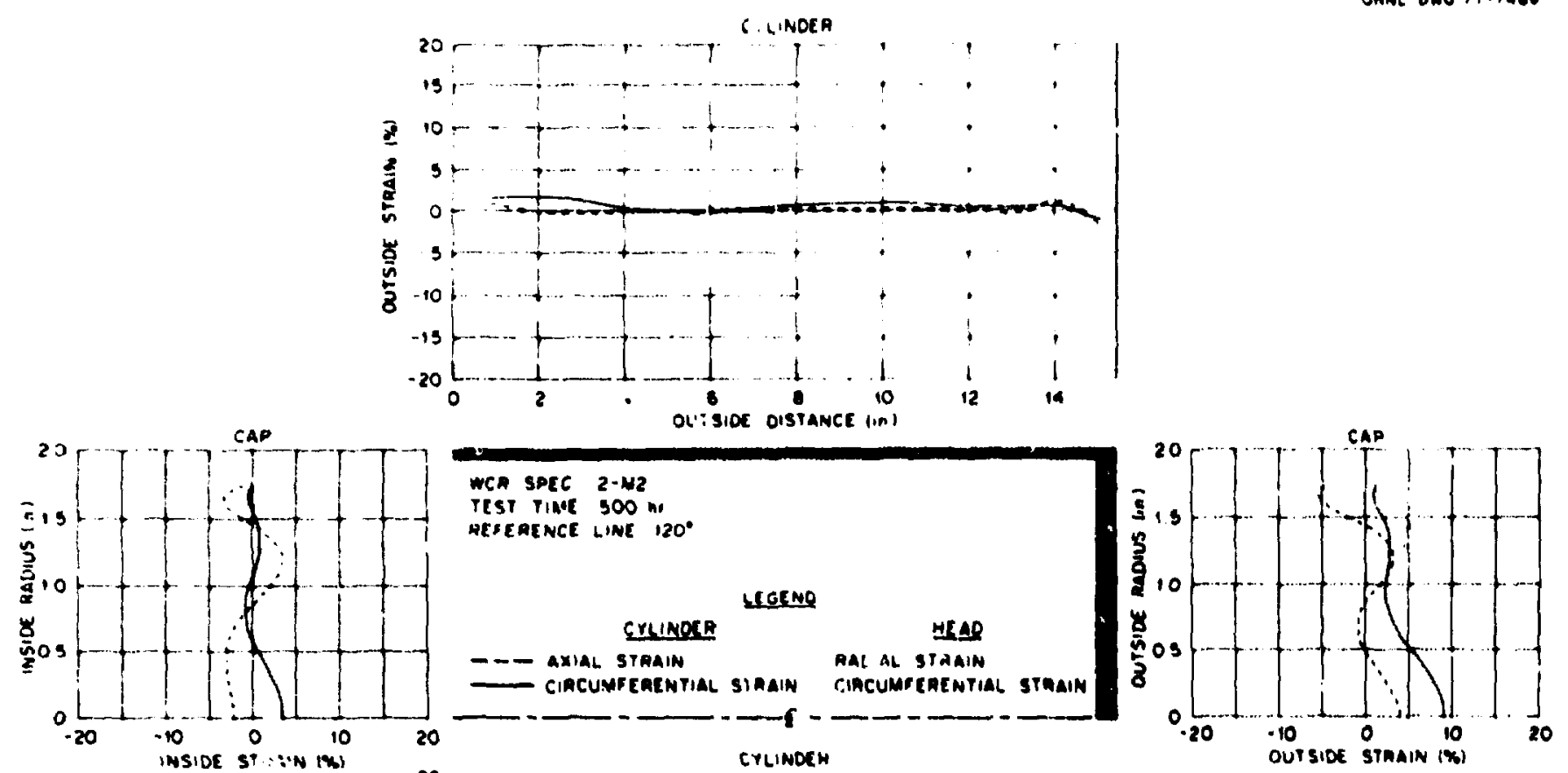

Fig. A8-c. Surface strain distribution for specimen 2-ke long the axial reference plane, $\theta=120^{\circ}$, at $500 \mathrm{hr}(1 \mathrm{in} .=2.54 \mathrm{~cm})$. 

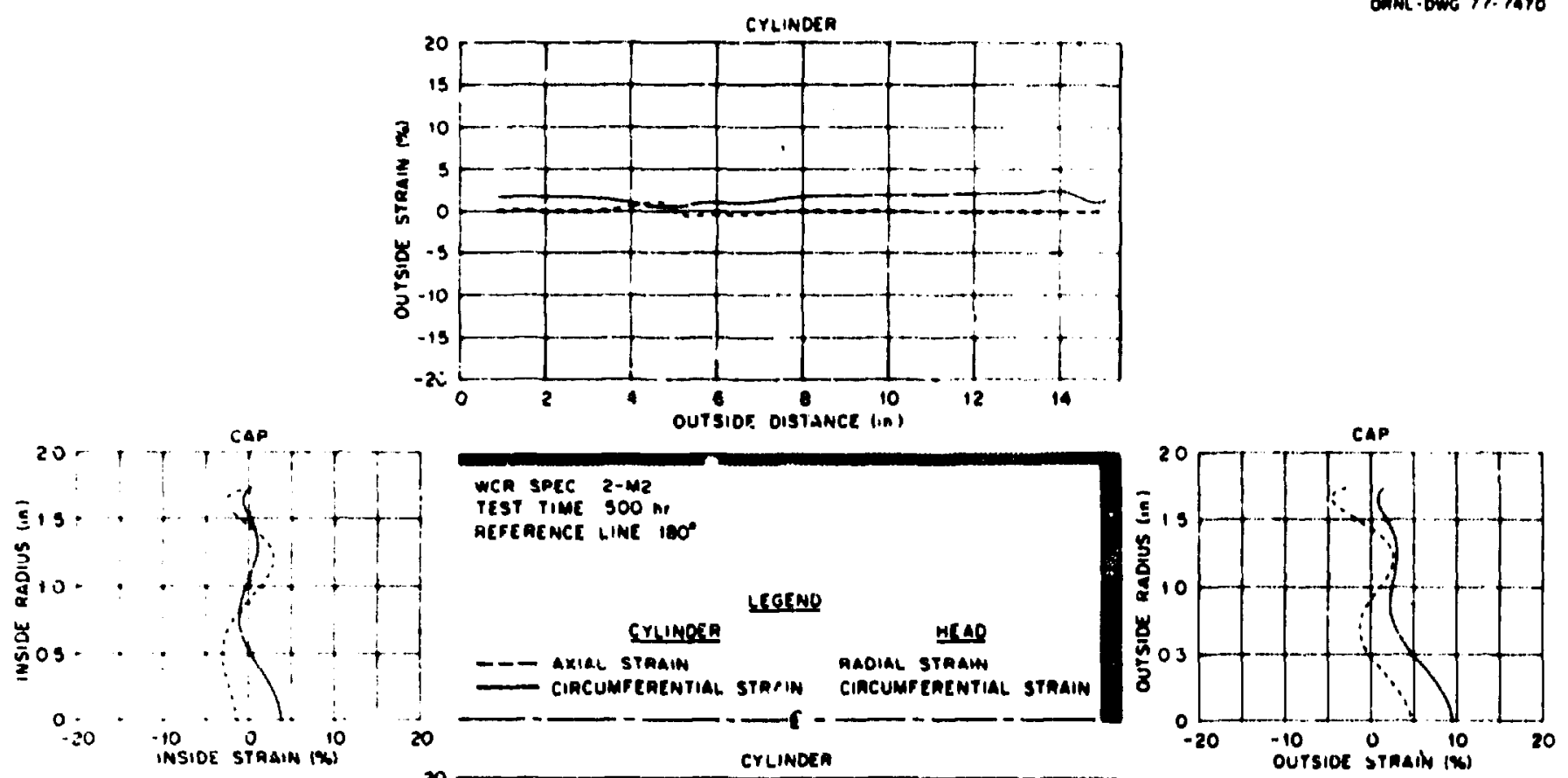

Fig. A8-d. Surface strain distribution for specimen 2-K2 alonf wide axial reference plane, $\theta=280^{\circ}$, at $500 \mathrm{hr}(1 \mathrm{ln} .=2.54 \mathrm{~cm}$ ). 

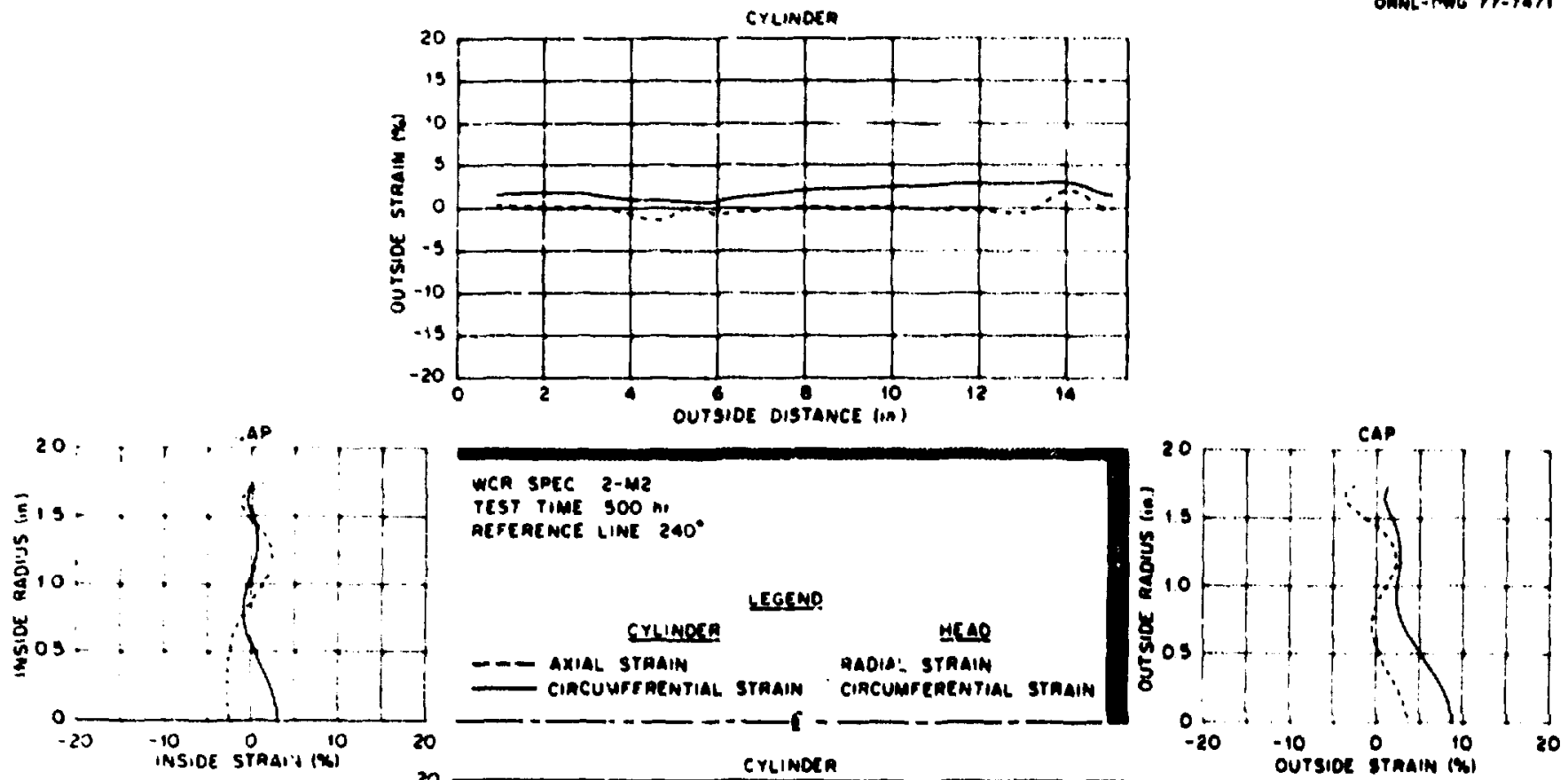

F1g. A8-e. Surface strain distribution for specimen 2-k2 along the axial reference plane, $\theta=240^{\circ}$, at $500 \mathrm{hr}(1 \mathrm{in} .=2.54 \mathrm{~cm})$. 


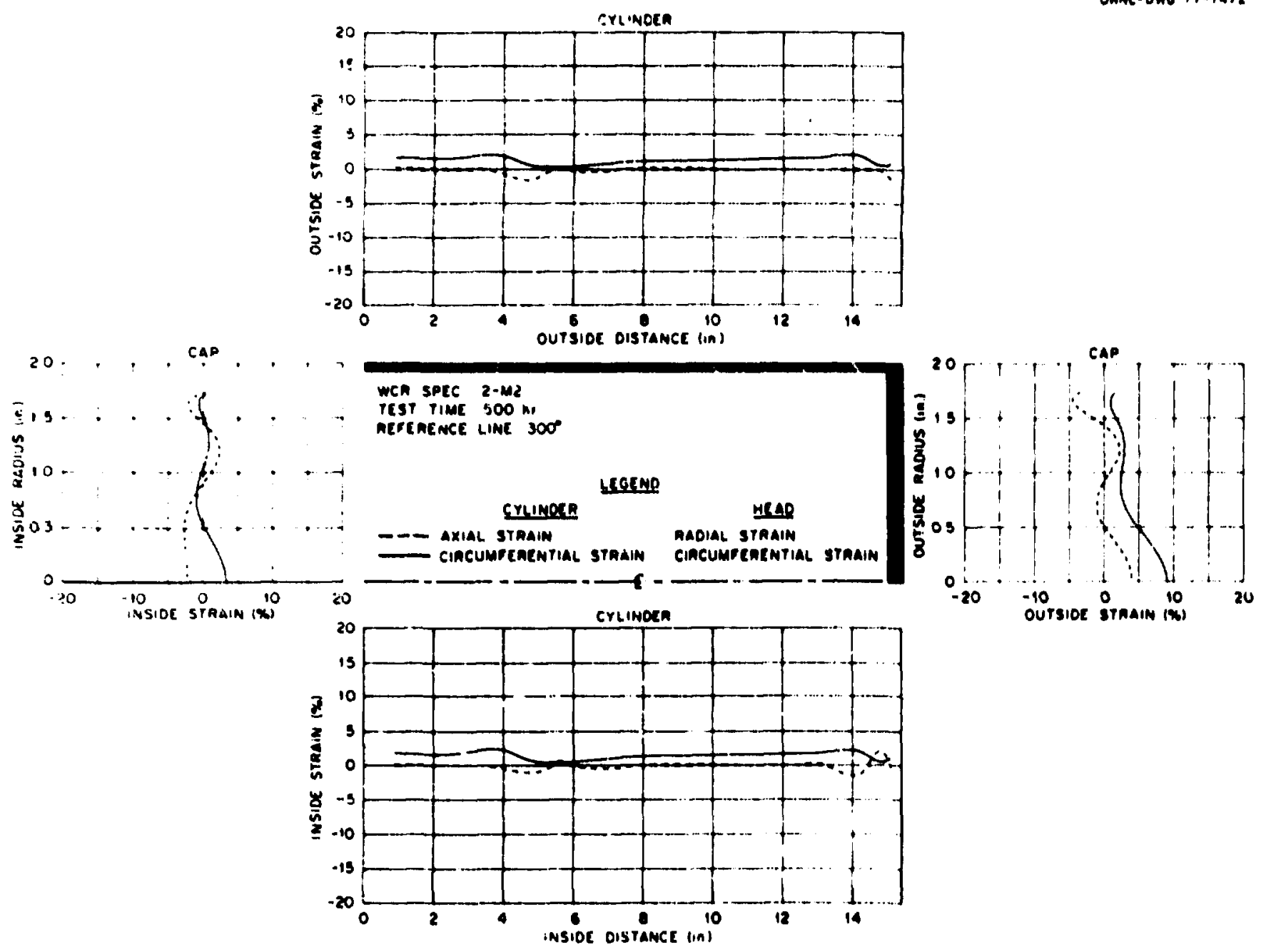

F1g. A8-r. Surface strain distribution for specirion 2-ke alc is the axtal refezence plane, $\theta=300^{\circ}$, at $500 \mathrm{hr}(+\mathrm{In} .=2.54 \mathrm{~cm})$. 

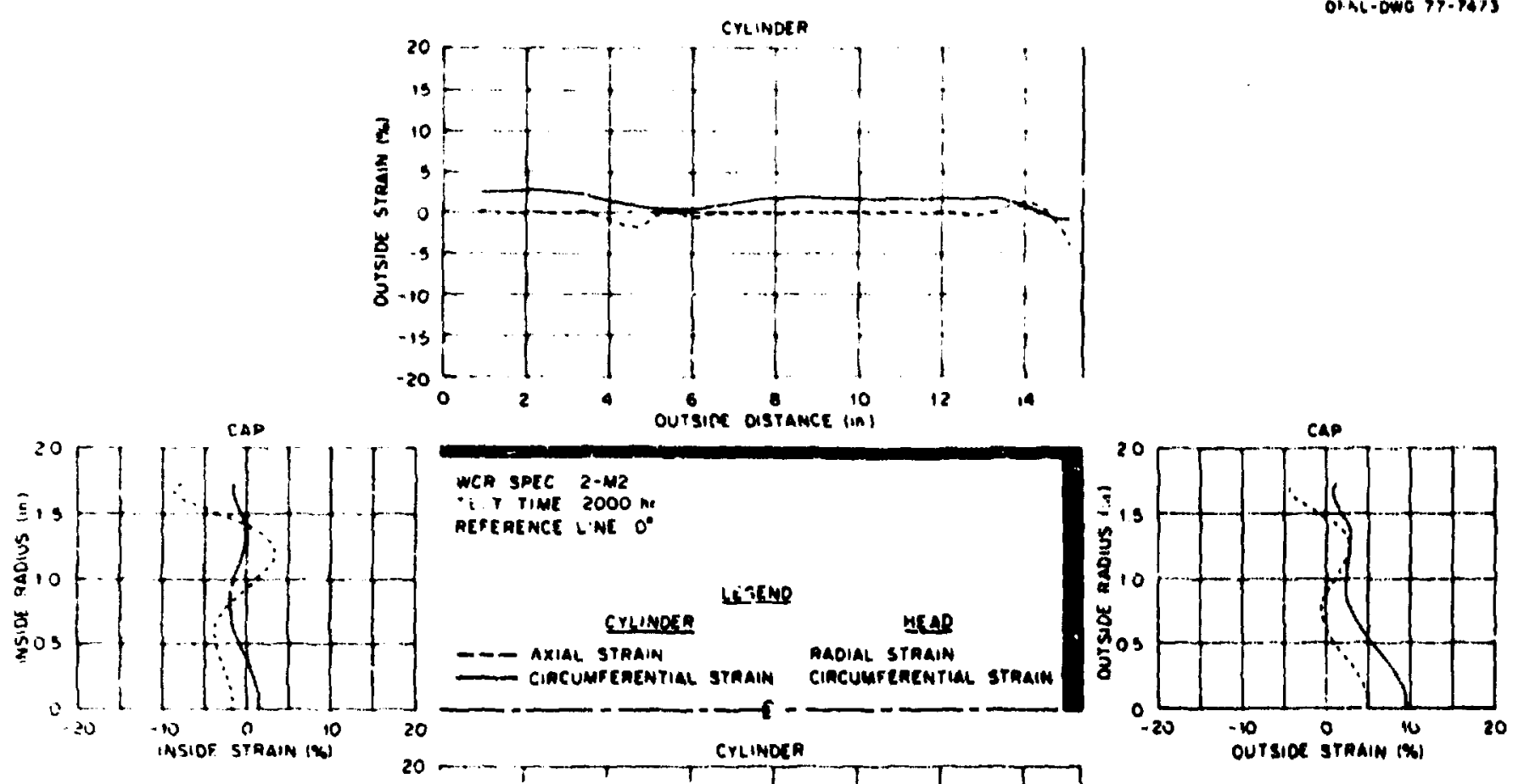

Fig. A9-8, Surface strain distribution for specimen 2-Me along the axial reference plane, $\theta=0^{\circ}$, at $2000 \mathrm{hr}$ ( 1 in. $=2.54 \mathrm{~cm}$ ). 

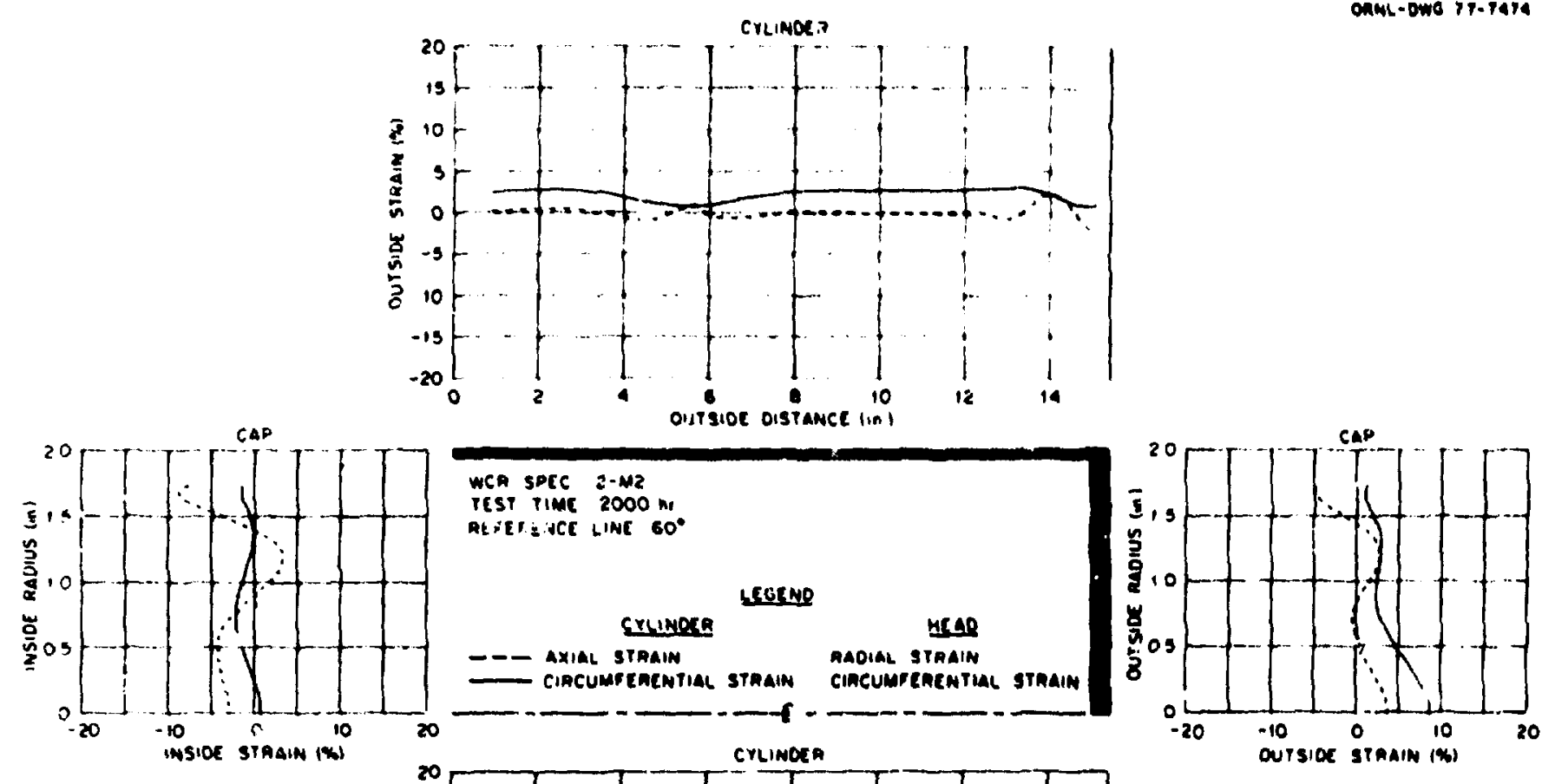

Fig. A-b-b. Surface strain distribution for specimen 2-Me along the axtal reference plane, $\theta=60^{\circ}$, at $2000 \mathrm{hr}$ (1 in. $=2.54 \mathrm{~cm}$ ). 


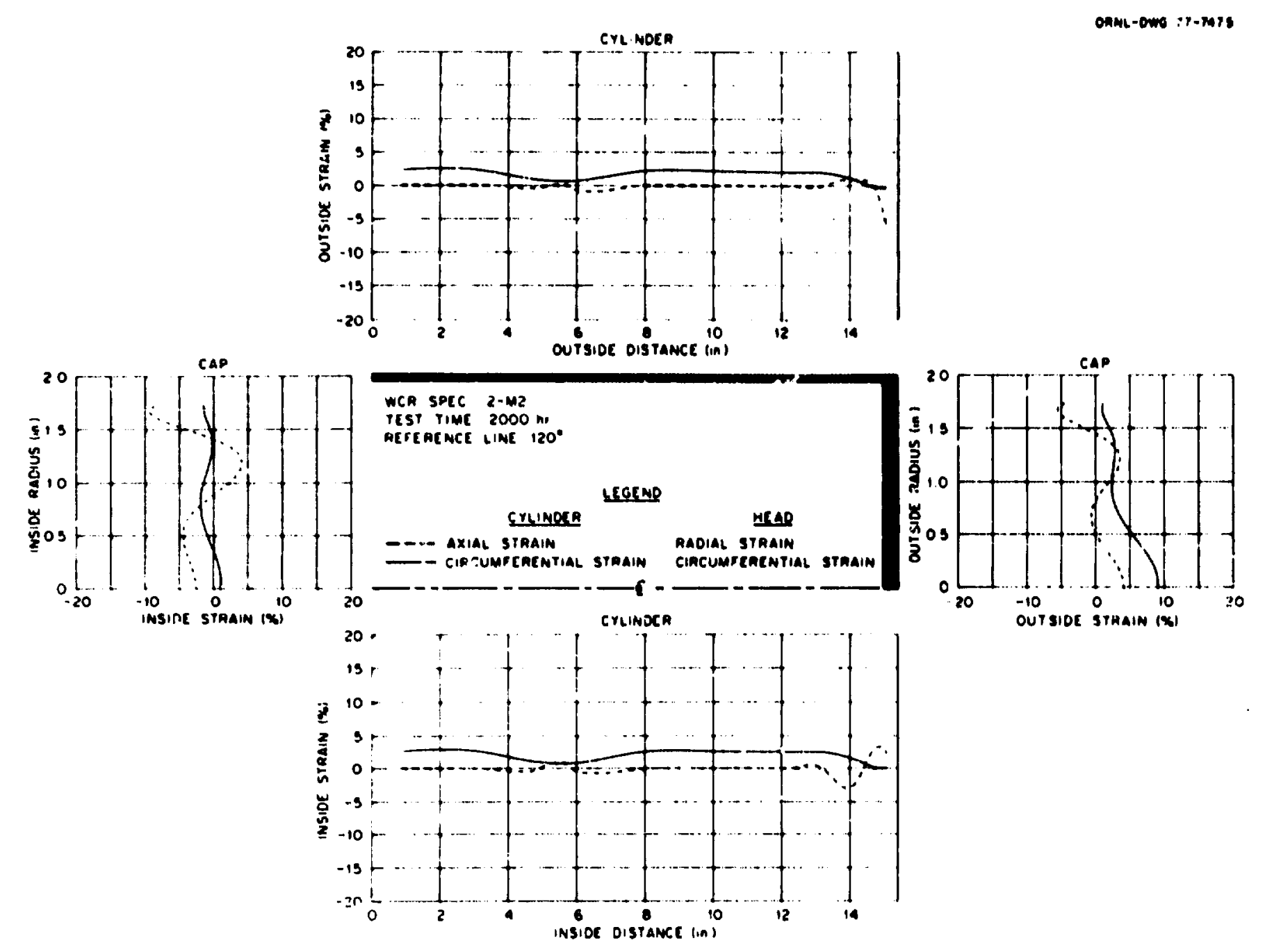

F1g. A9-c. Surface strain distribution for specimen 2-N2 along the axial reference plane, $\theta=120^{\circ}$, at $2000 \mathrm{hr}(1 \mathrm{ln} .=2.54 \mathrm{~cm})$. 

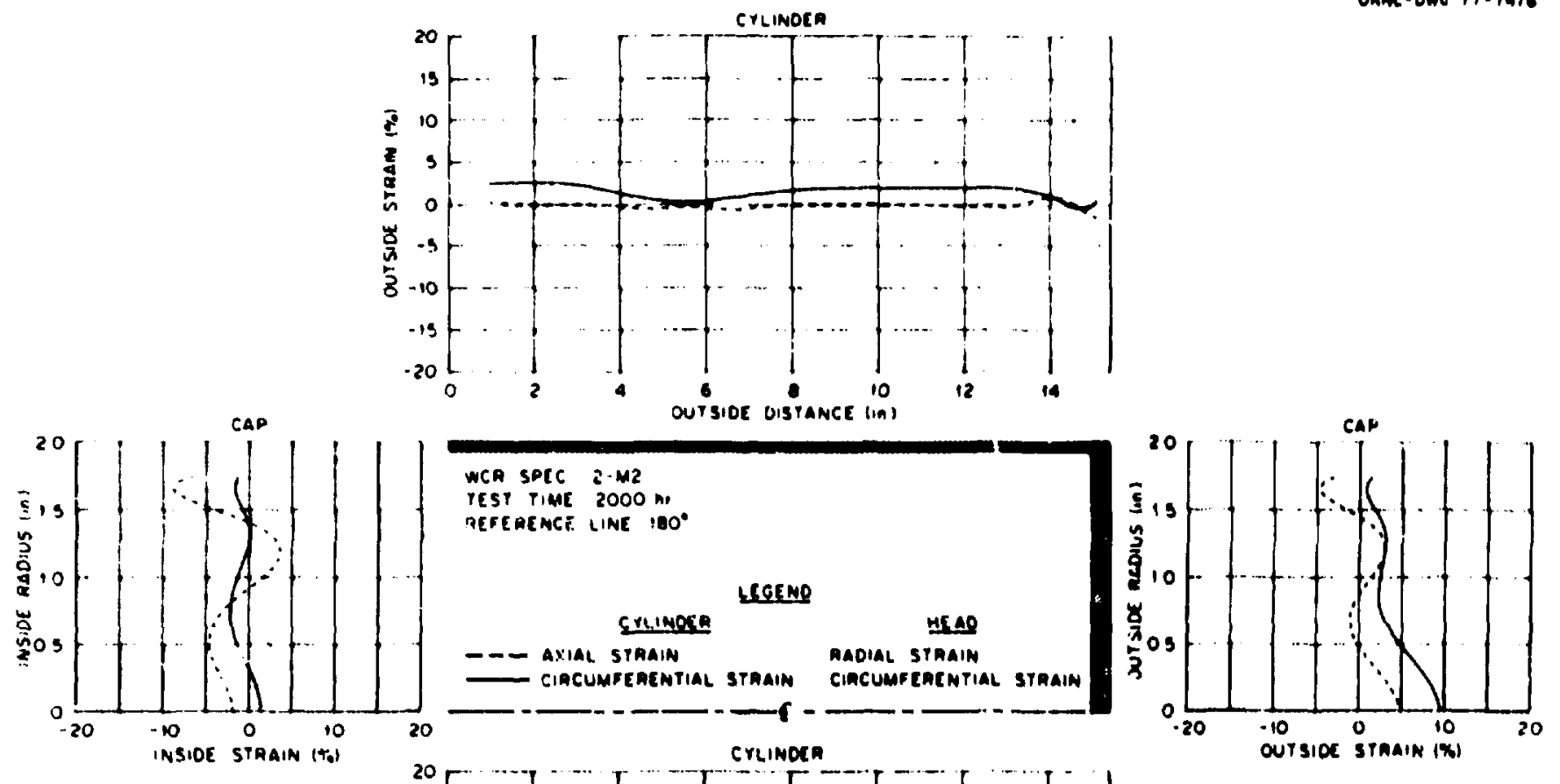

F1g. A9-d. Surface strain dist,ribution for specimen 2-K1 along the axtal reference plane, $\theta=180^{\circ}$, at $2000 \mathrm{hr}(1 \mathrm{ln},=2.54 \mathrm{~cm})$. 

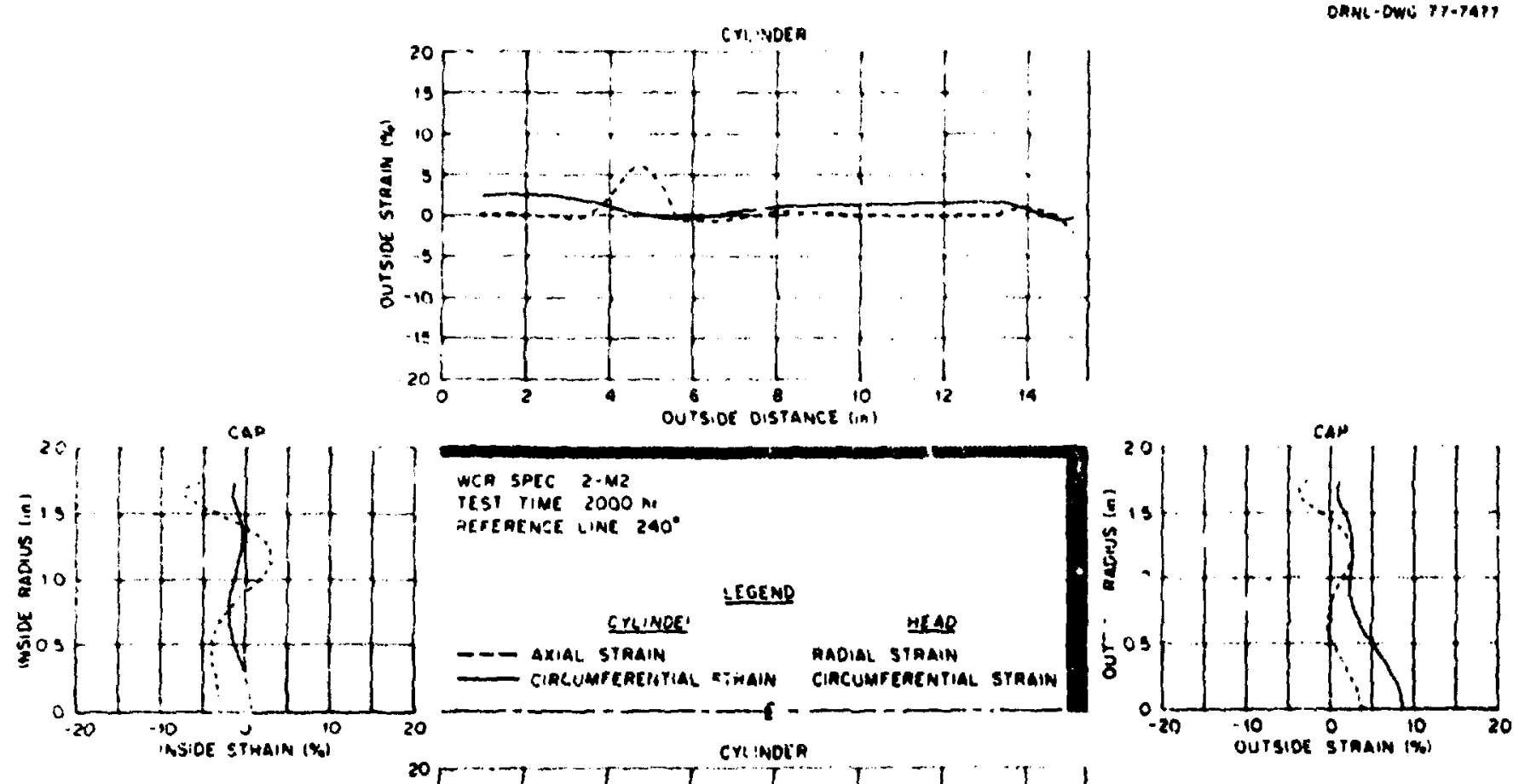

Fig. A9-e. Surface strain distribution for specimen 2-M2 along the axia reference plane, $\theta=240^{\circ}$, at $2000 \mathrm{hr}(1 \mathrm{in} .=2.54 \mathrm{~cm})$. 

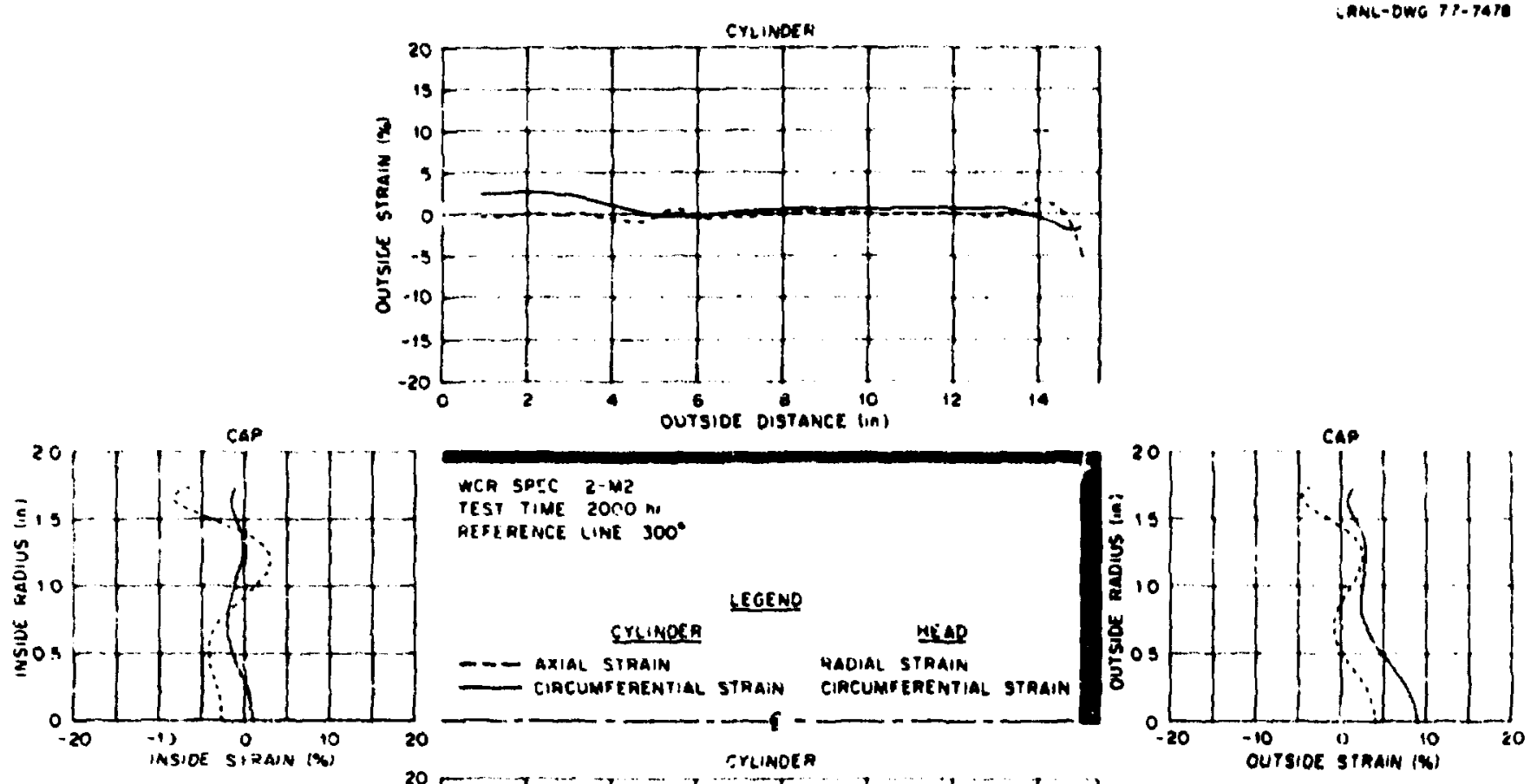

Fig. A9-f. Surfece atrain distribution for specimen 2-Me along the axial reference plane, $\theta=300^{\circ}$, at $2000 \mathrm{hr}$ ( $1 \mathrm{in}$. $=2.54 \mathrm{~cm}$ ). 


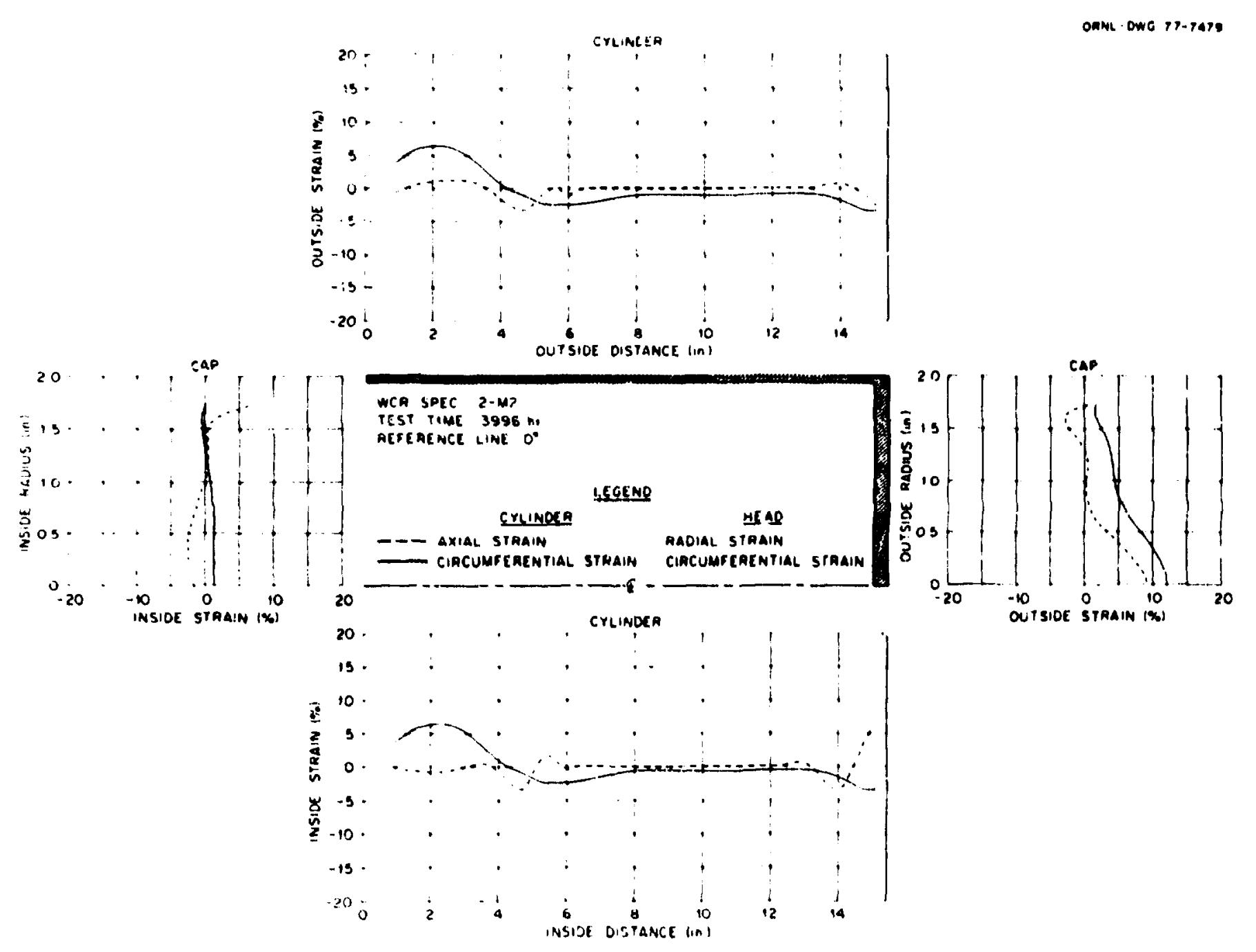

Fig. AlO-a. Surface strain distribution for specimen 2-M2 along the axial reference plane, $\theta_{.}=0^{\circ}$, at $3996 \mathrm{hr}(1 \mathrm{ln} .=2.54 \mathrm{~cm})$. 


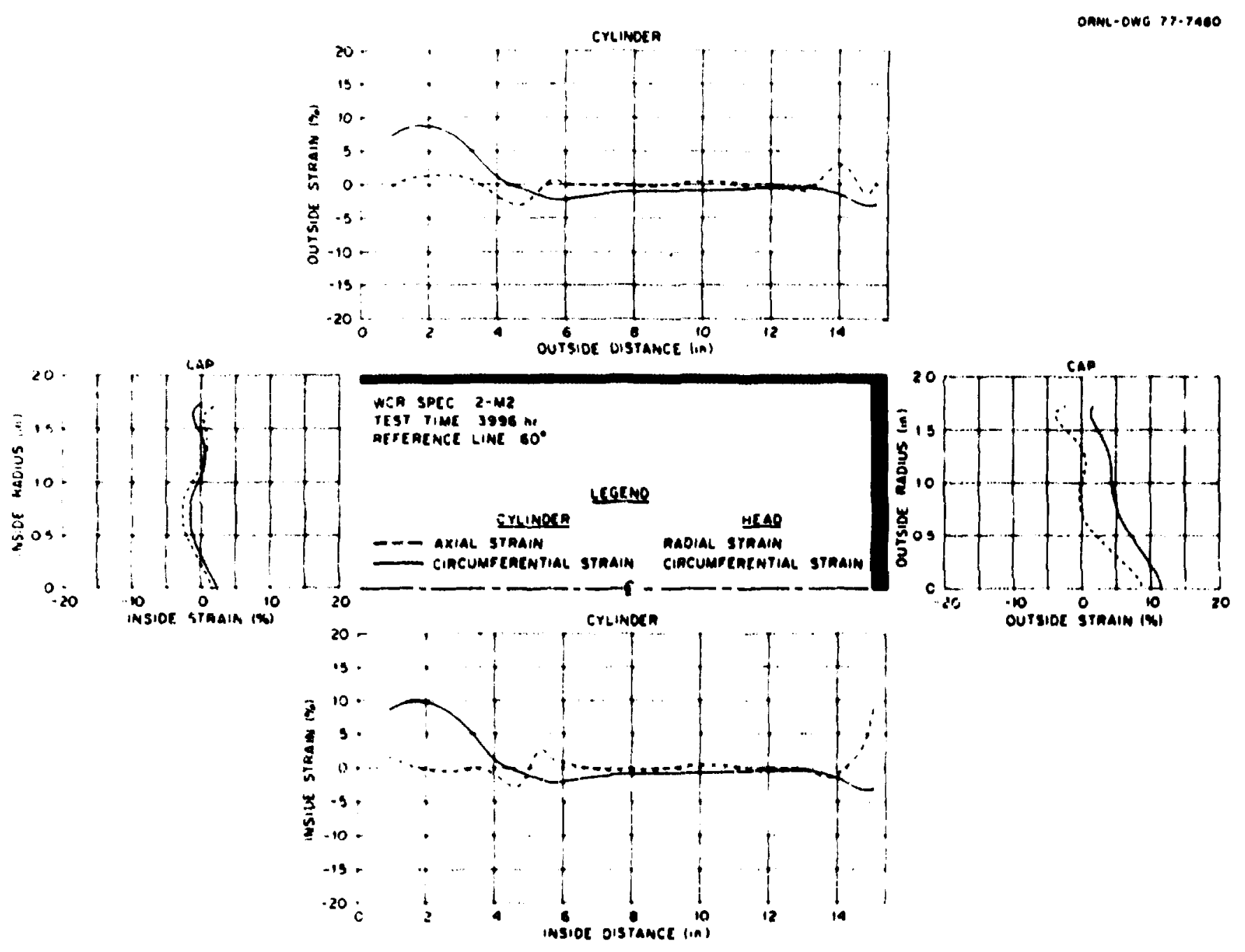

F18. Al0-b. Surface strain distribution for specinen 2-M2 along the axtal reference plane, $\theta=60^{\circ}$, at $3996 \mathrm{hr}$ (1 $\mathrm{in} .=2.54 \mathrm{~cm}$ ). 


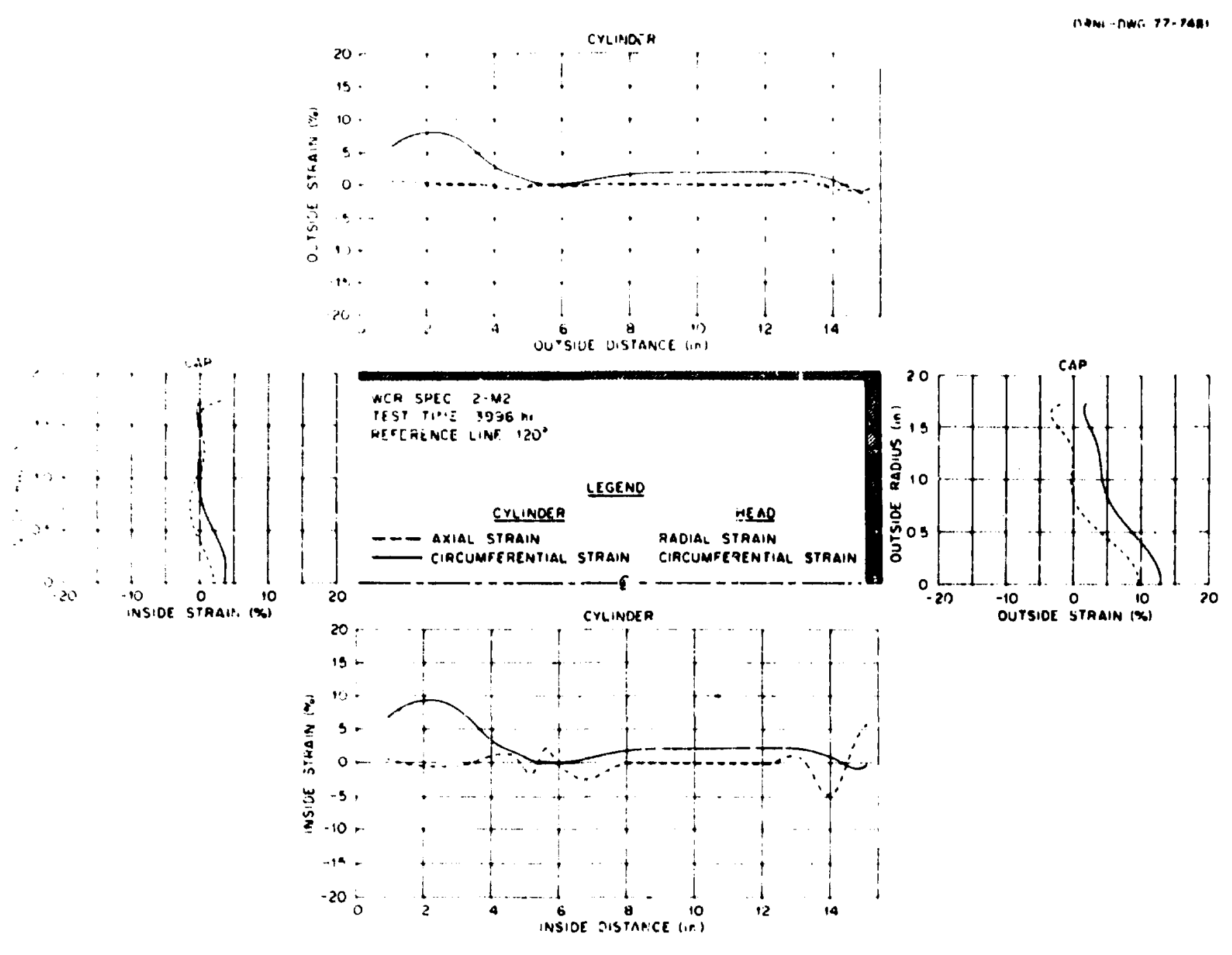

Fig. AlO-c. Surface strain distribution for specimen 2-M2 along the axial reference piane, $G=120^{\circ}$, at $3996 \mathrm{hr}(1 \mathrm{in} .=2.54 \mathrm{~cm})$. 


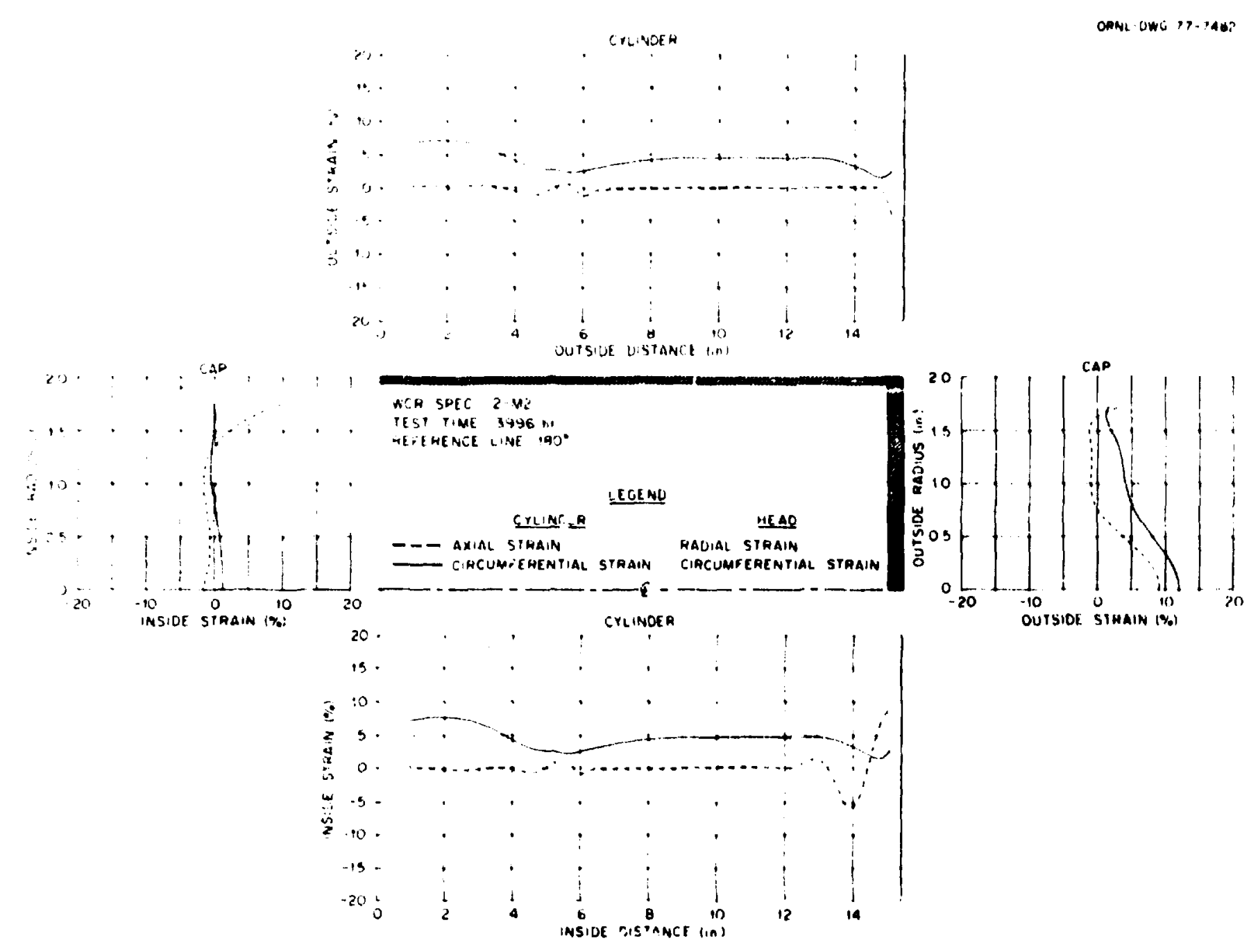

Fig. Al0-d. Surface strain distribution for specimen 2-M2 along the axtal reference plane, $\theta=180^{\circ}$, at $3996 \mathrm{hr}(1 \mathrm{ln} .=2.54 \mathrm{~cm})$. 


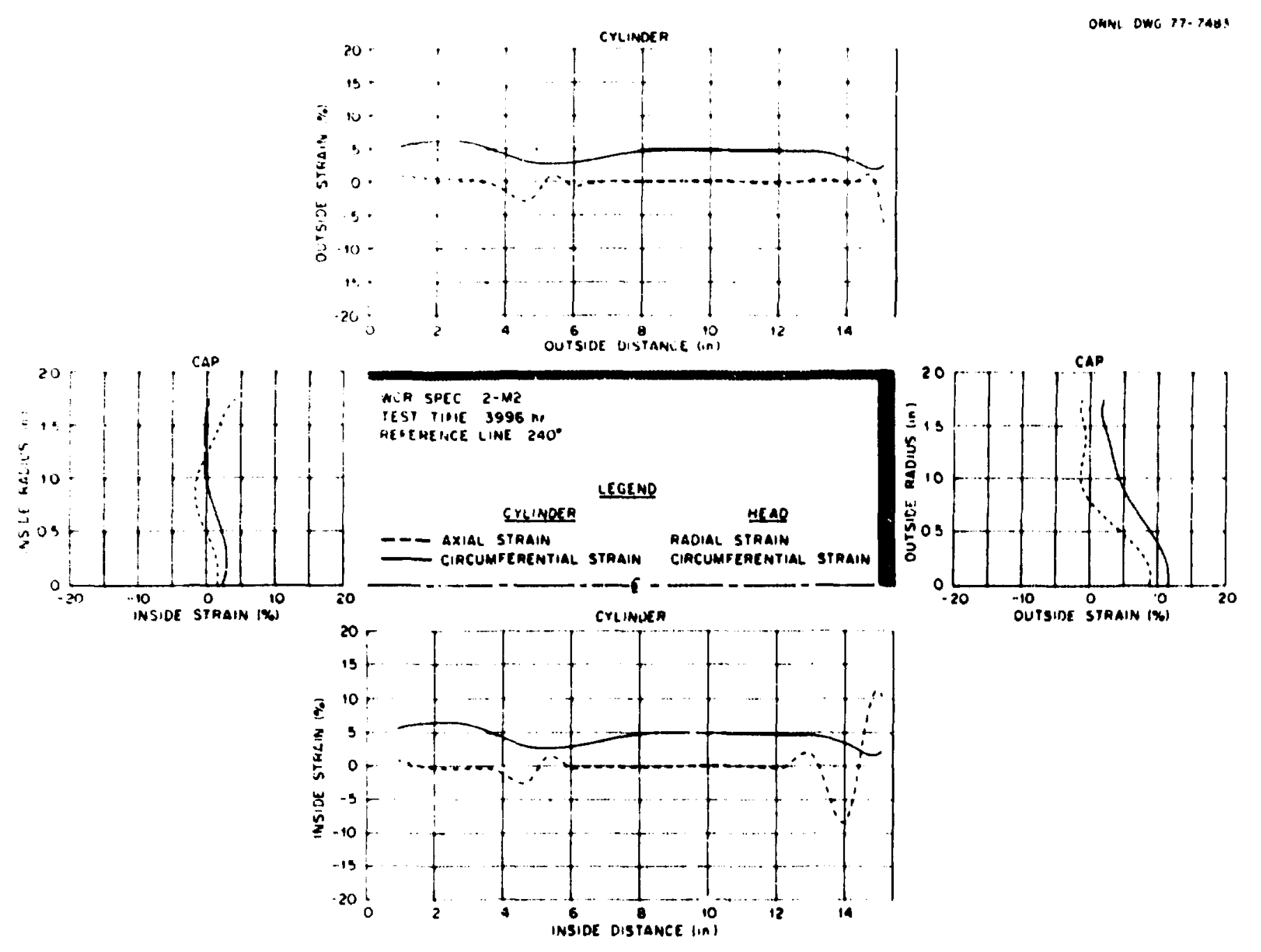

Fig. AlO-e. Surface strain distribution for specimen 2-M2 along the axial reference plane, $\theta=240^{\circ}$, at $3996 \mathrm{hr}(1 \mathrm{in} .=2.54 \mathrm{~cm}$ ). 

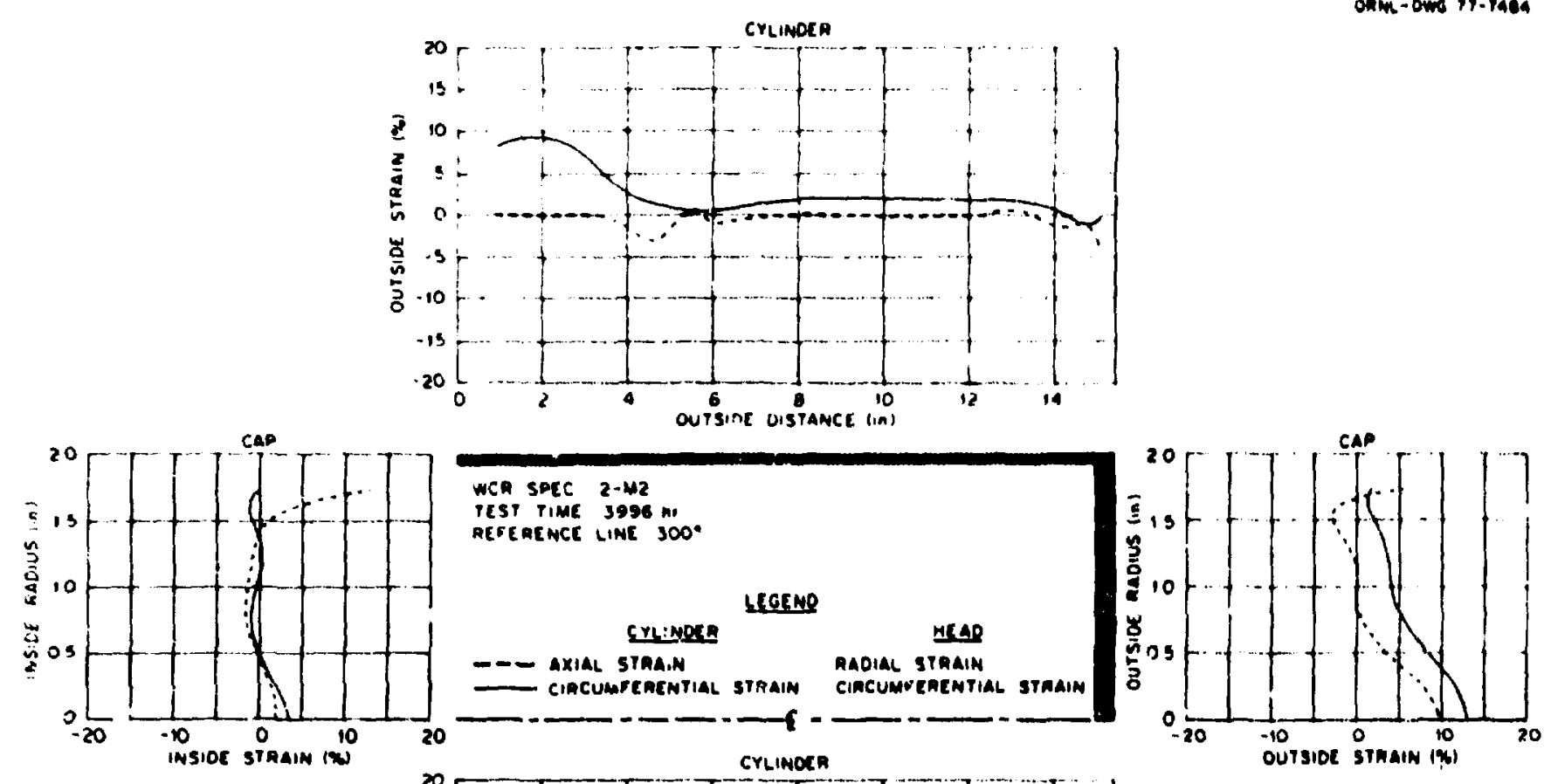

F1g. Al0-f. Surface strain distribution for specimen 2-M2 along the axtal reference plane, $\theta=300^{\circ}$, at $3996 \mathrm{hr}(1 \mathrm{in} .=2.54 \mathrm{~cm}$ ). 


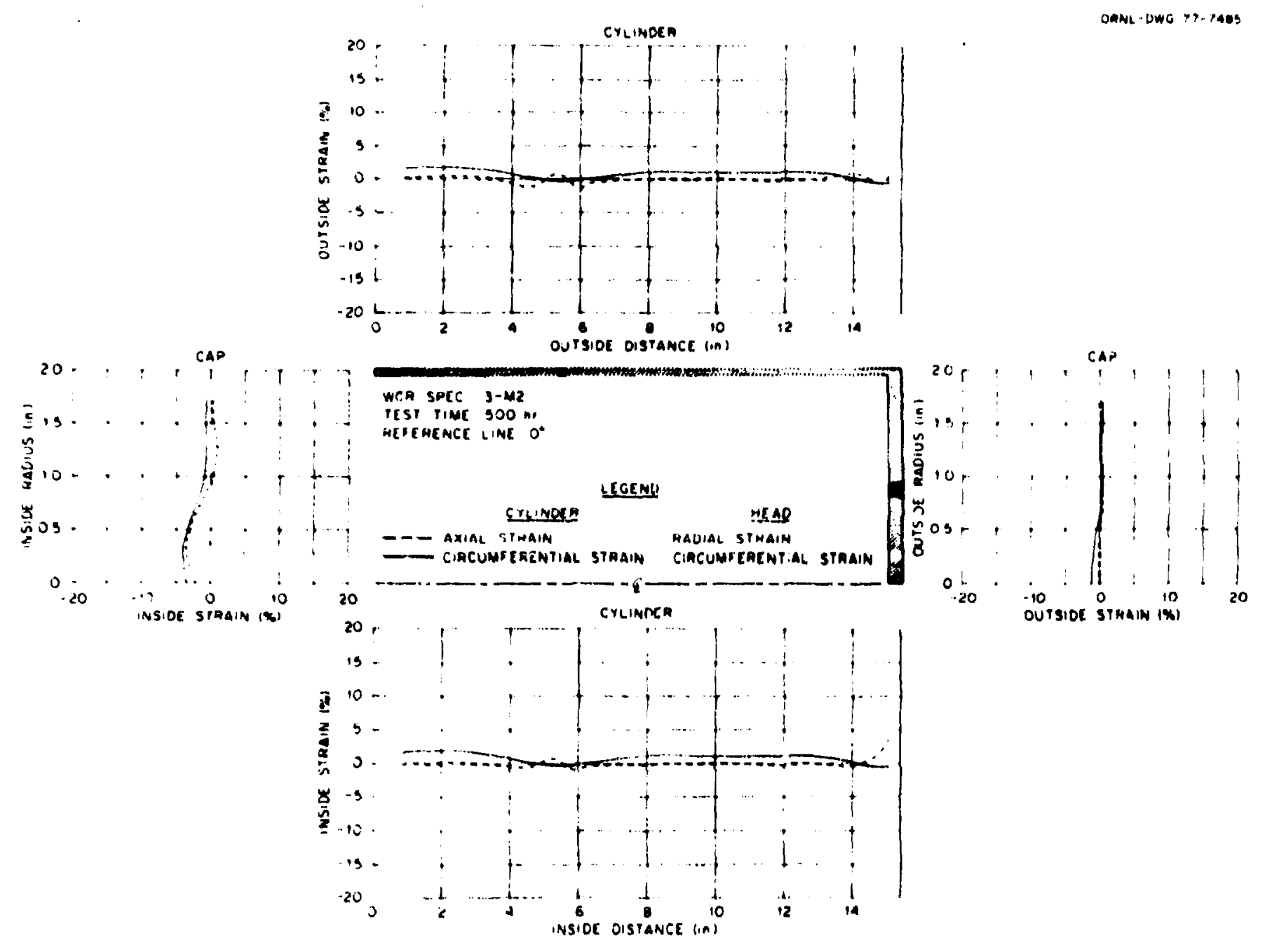

F18. All-a. Surface strain distribution for specimen 3-M2 along the axial reference plane, $\theta=0^{\circ}$, at $500 \mathrm{hr}(1 \mathrm{ln}$. $=2.54 \mathrm{~cm}$ ). 

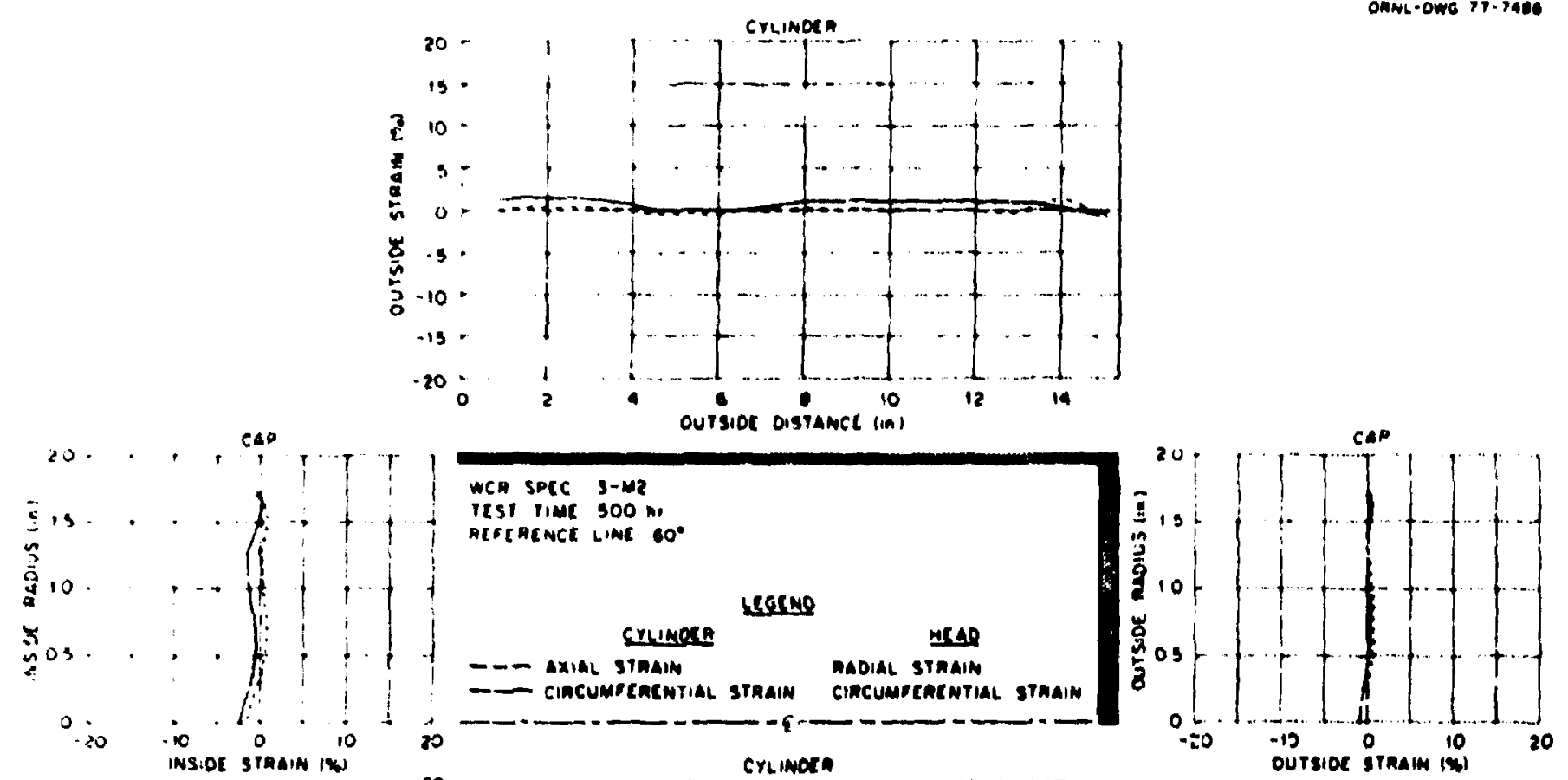

F18. Al1-b. Surface atrain diatribution for specimen 3-We alows the axtal reference plane, $\theta=60^{\circ}$, at $500 \mathrm{hr}(1 \mathrm{ln}$. $=2.54 \mathrm{~cm})$. 

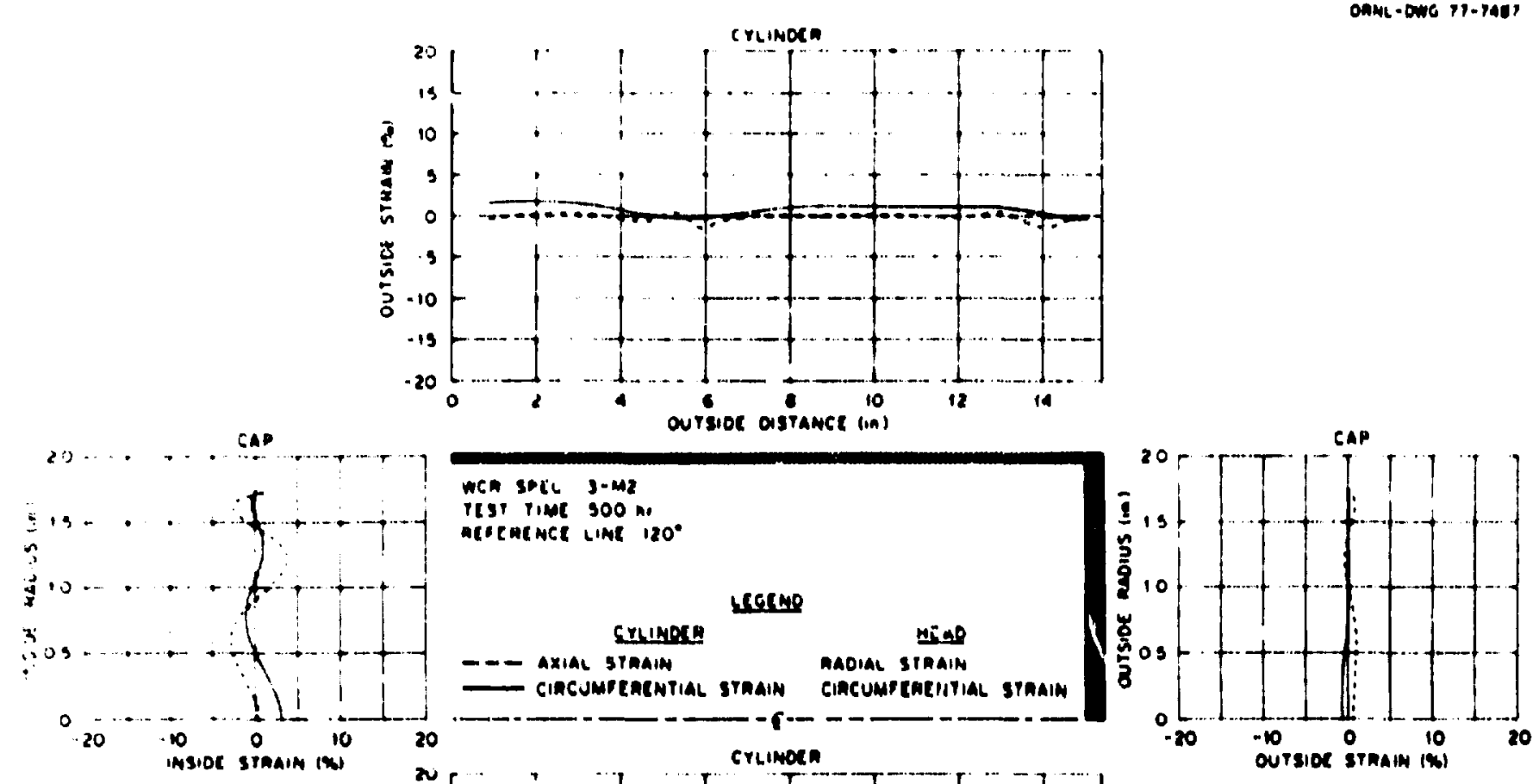

F1g. A22-c. Surface atrain diatribution for specimen 3-K2 along the axtal reference plane, $\theta=120^{\circ}$, at $500 \mathrm{hr}(1 \mathrm{ln} .=2.54 \mathrm{~cm})$. 

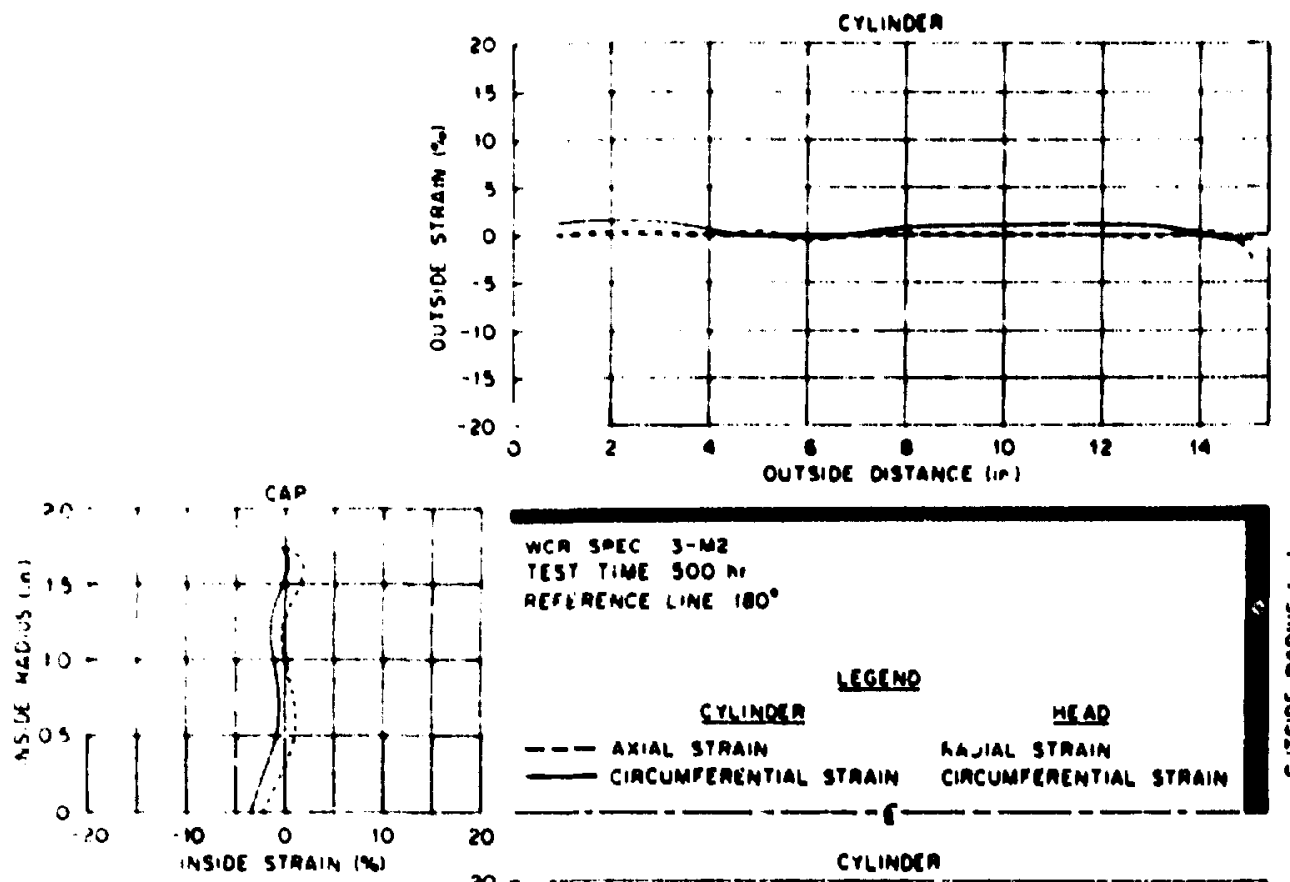

\section{WCA SOEC 3-Ma}

IEsT Pine $500 \mathrm{nt}$

ReriacmeE LIME $100^{\circ}$

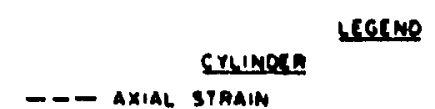

- - axial sTrain Ciacumitanintial staAin

20
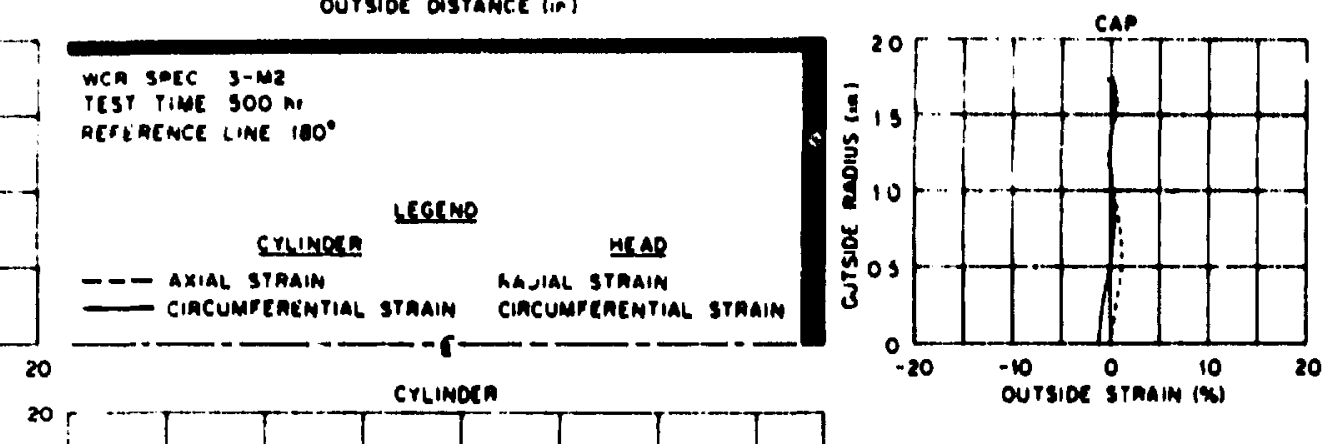

Flg. All-d. Surface strain distribution for specimen 3-Ma along the axial reference plane, $\theta=180^{\circ}$, at $500 \mathrm{hr}$ ( $1 \mathrm{in} .=2.54 \mathrm{~cm}$ ). 

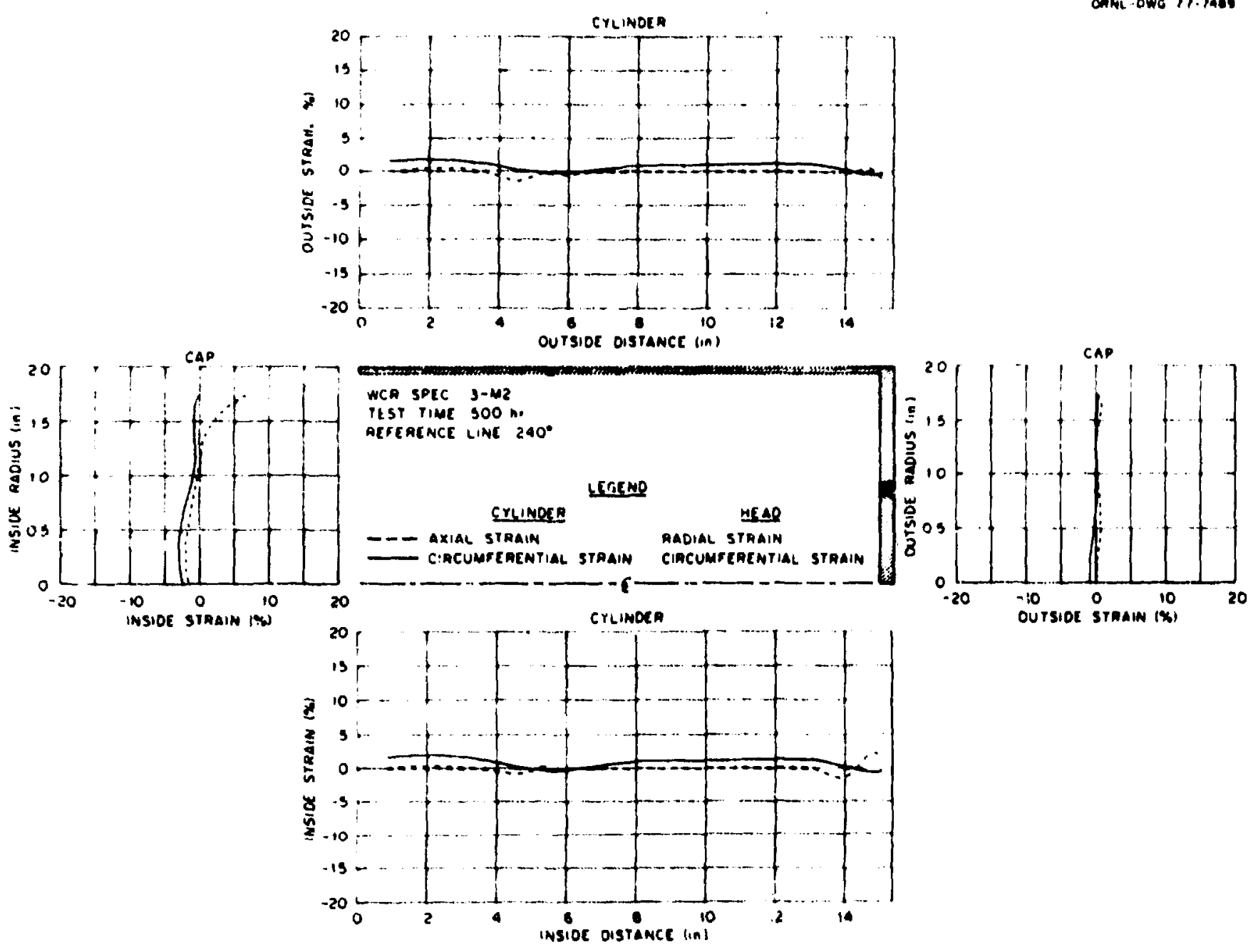

F18. Al1-e. Surface strain distribution for specimen 3-M2 along the axtal reference plane, $\theta=240^{\circ}$, at $500 \mathrm{hr}(1 \mathrm{ln} .-2.54 \mathrm{~cm})$. 

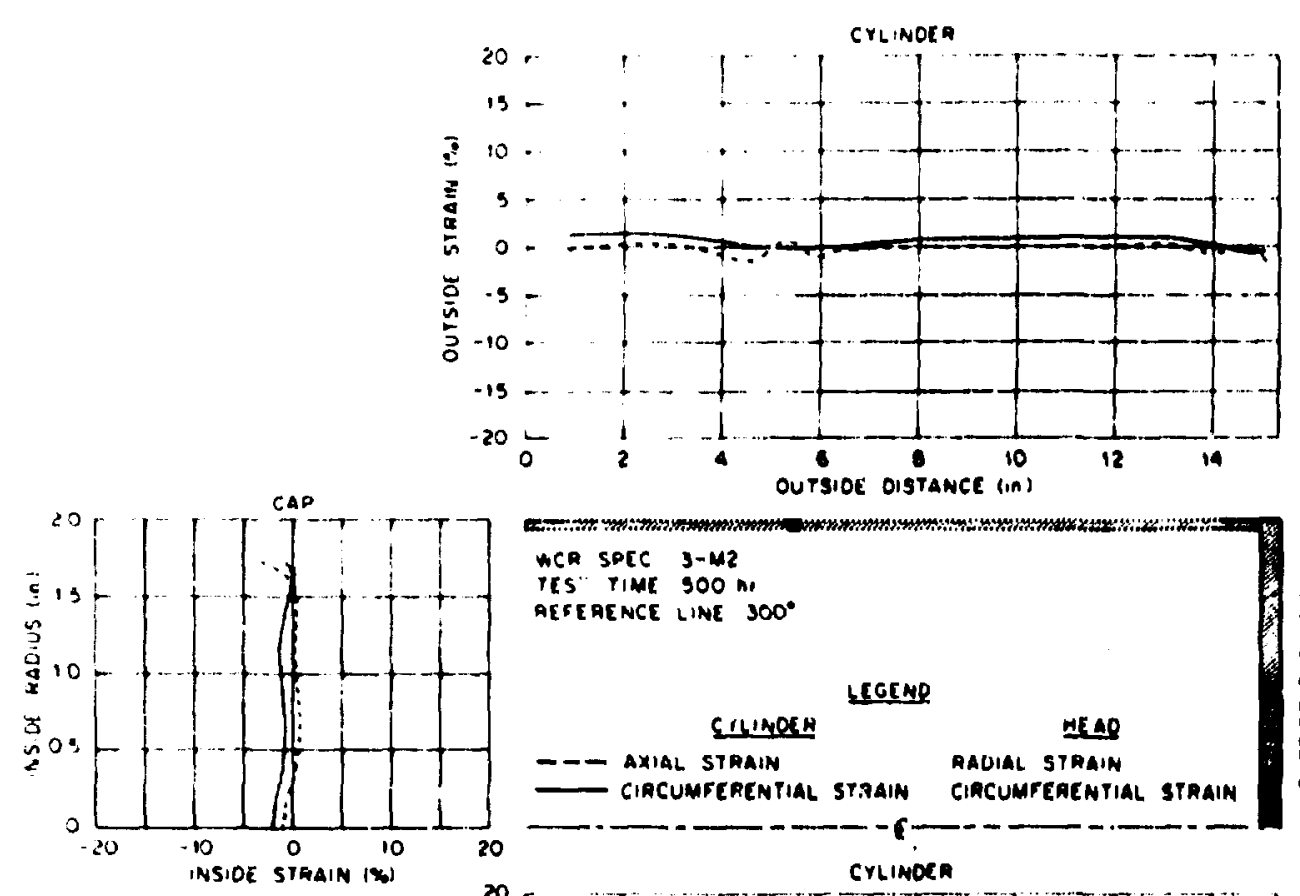

HCR SPCC $3-M 2$

CS" rIME 900 ni

AESEAENCE LINE $300^{\circ}$

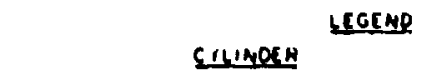

-D AXIAL STRAIN

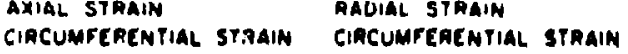

20

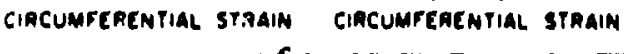
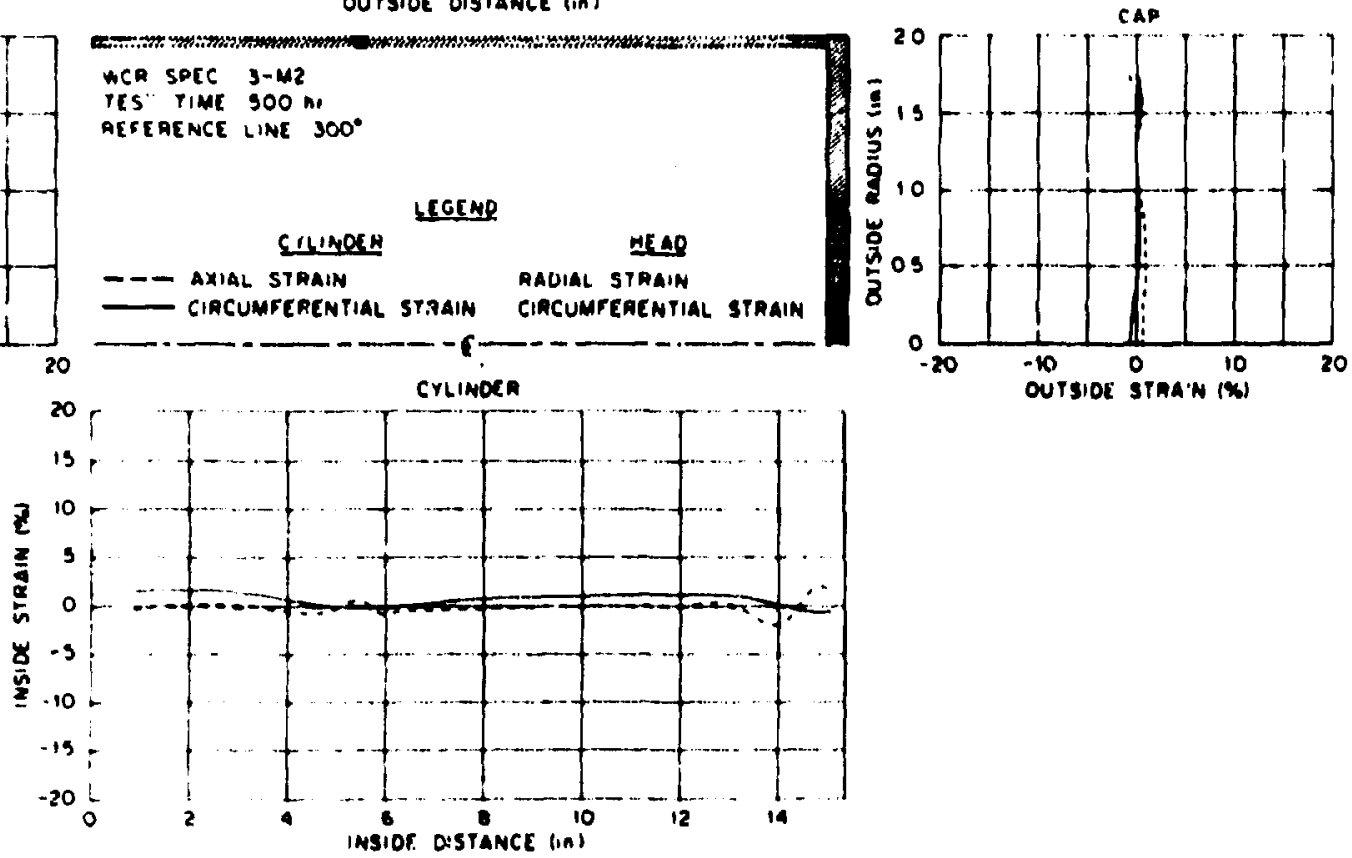

F18. All-f. Surface strain distribution for specinen 3-Me along the axial reference plane, $\theta=300^{\circ}$, at $500 \mathrm{hr}(1 \mathrm{in} .=2.54 \mathrm{~cm})$. 

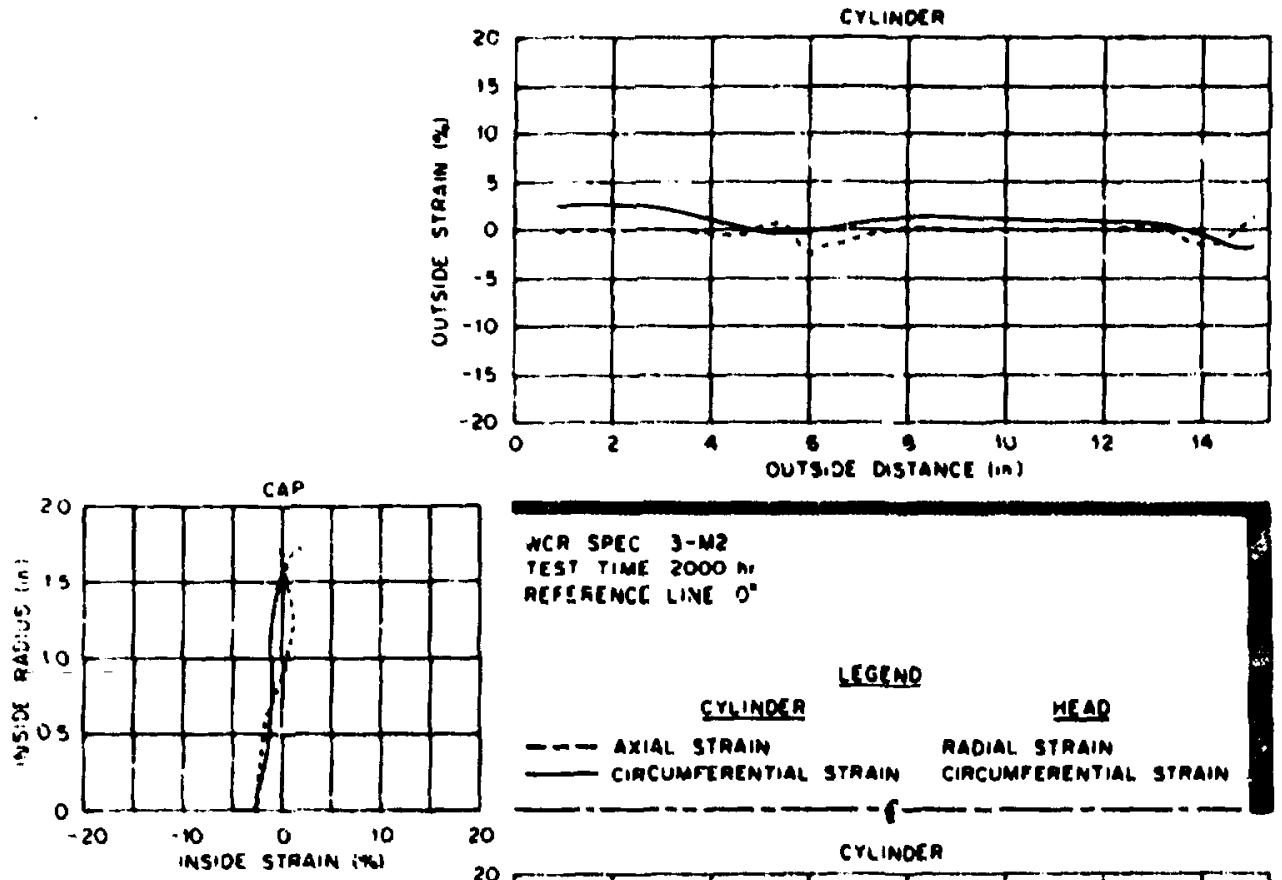

$$
\begin{aligned}
& \text { WCA SPEC } 3-112 \\
& \text { TEST TINE } 2000 \text { n: } \\
& \text { RESGEECE LINE O" }
\end{aligned}
$$

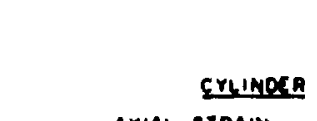

\section{- - AXIAL STRAIN}

CIMCUMFTAENTIAL STAAIM

LEGEO

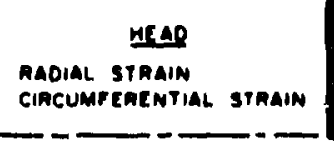

20
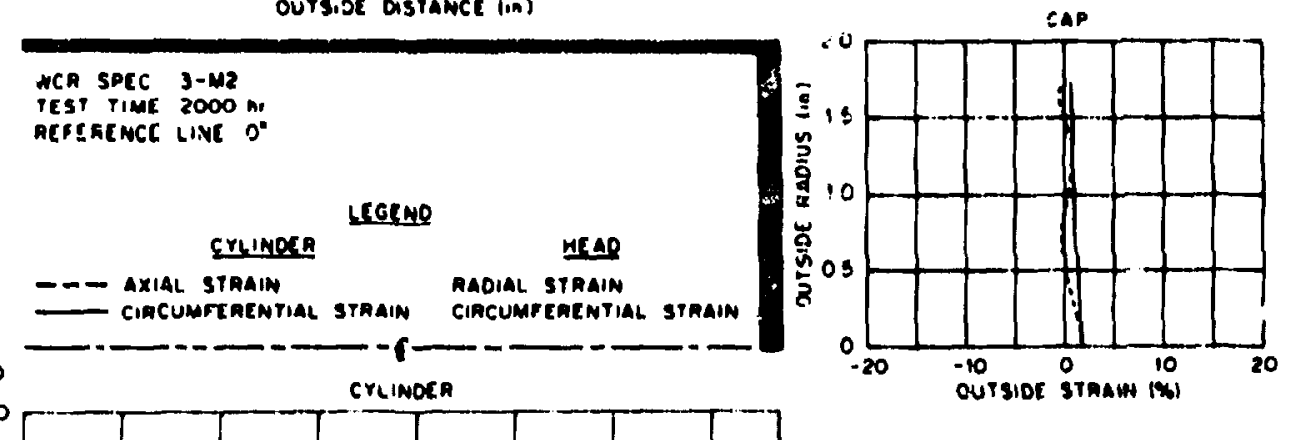

Fig. A12-a. Surface strain distribution for specimen 3-K2 along the axia] reference plane, $\theta=0^{\circ}$, at $2000 \mathrm{hr}(1 \mathrm{ln} .=2.54 \mathrm{~cm})$. 

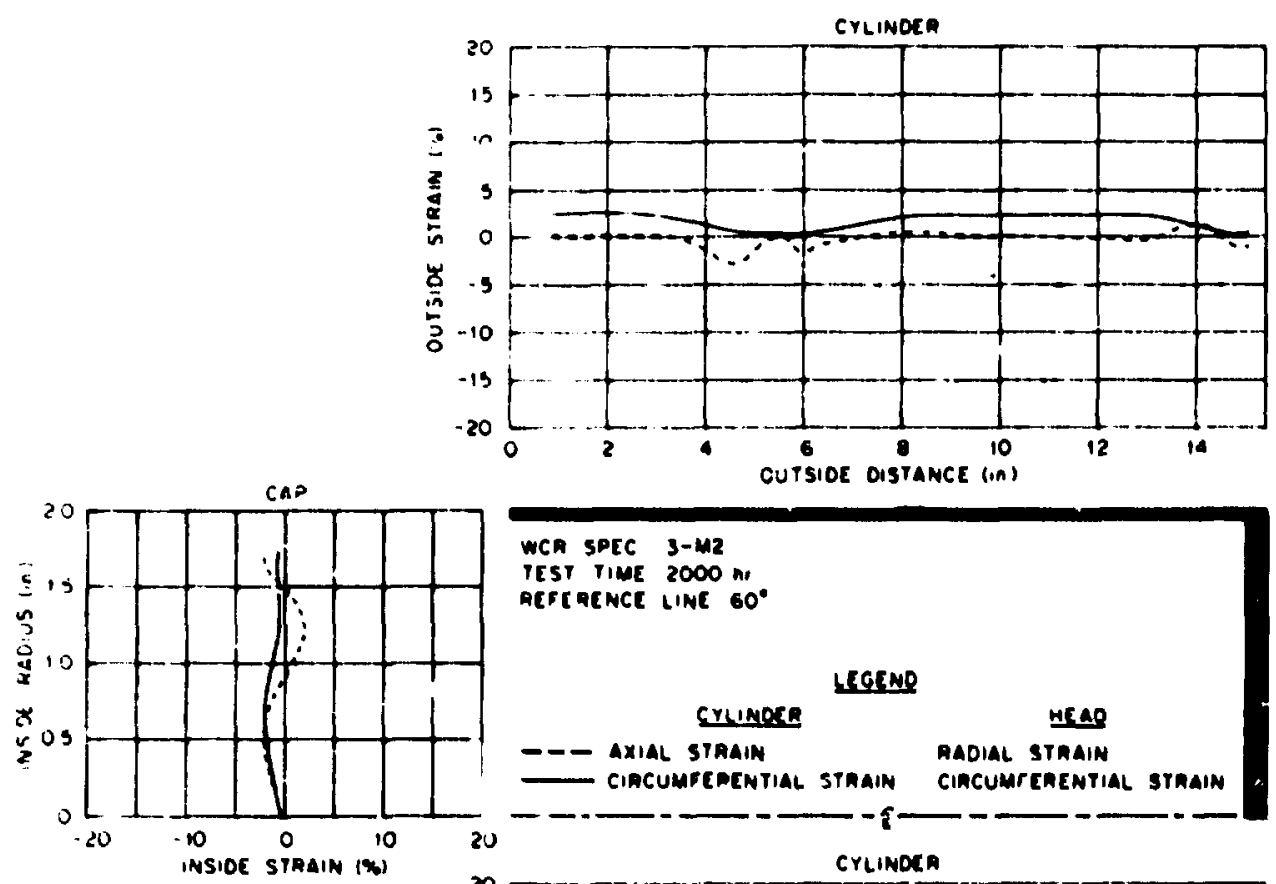

WCA SPEC 3-MU2 PEST TINE 2000 n'
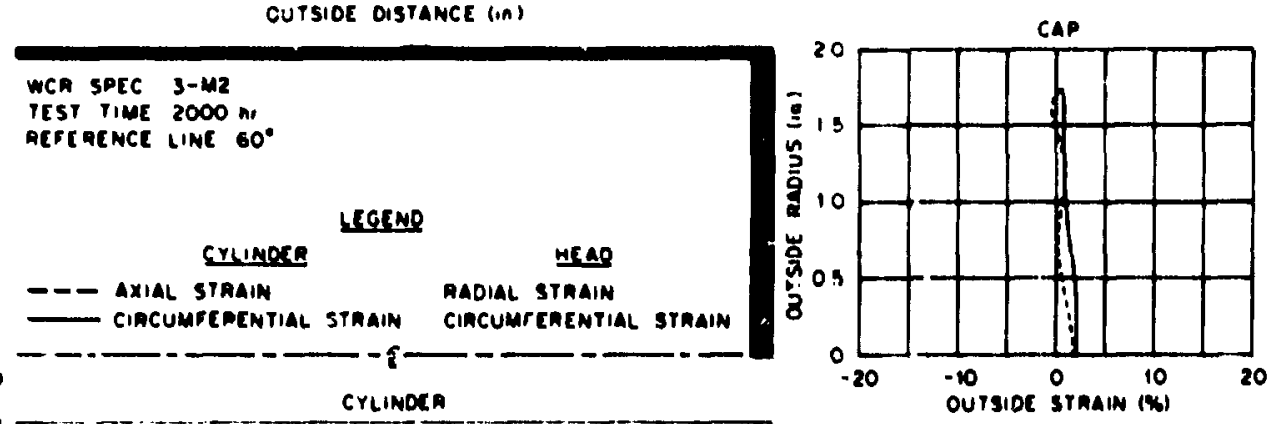

F1g. Al2-b. Surface strain distribution for spscimen 3-M2 along thr axtal reference plane, $\theta=60^{\circ}$, at $2000 \mathrm{hr}(1 \mathrm{in}$. $=2.54 \mathrm{~cm}$ ). 

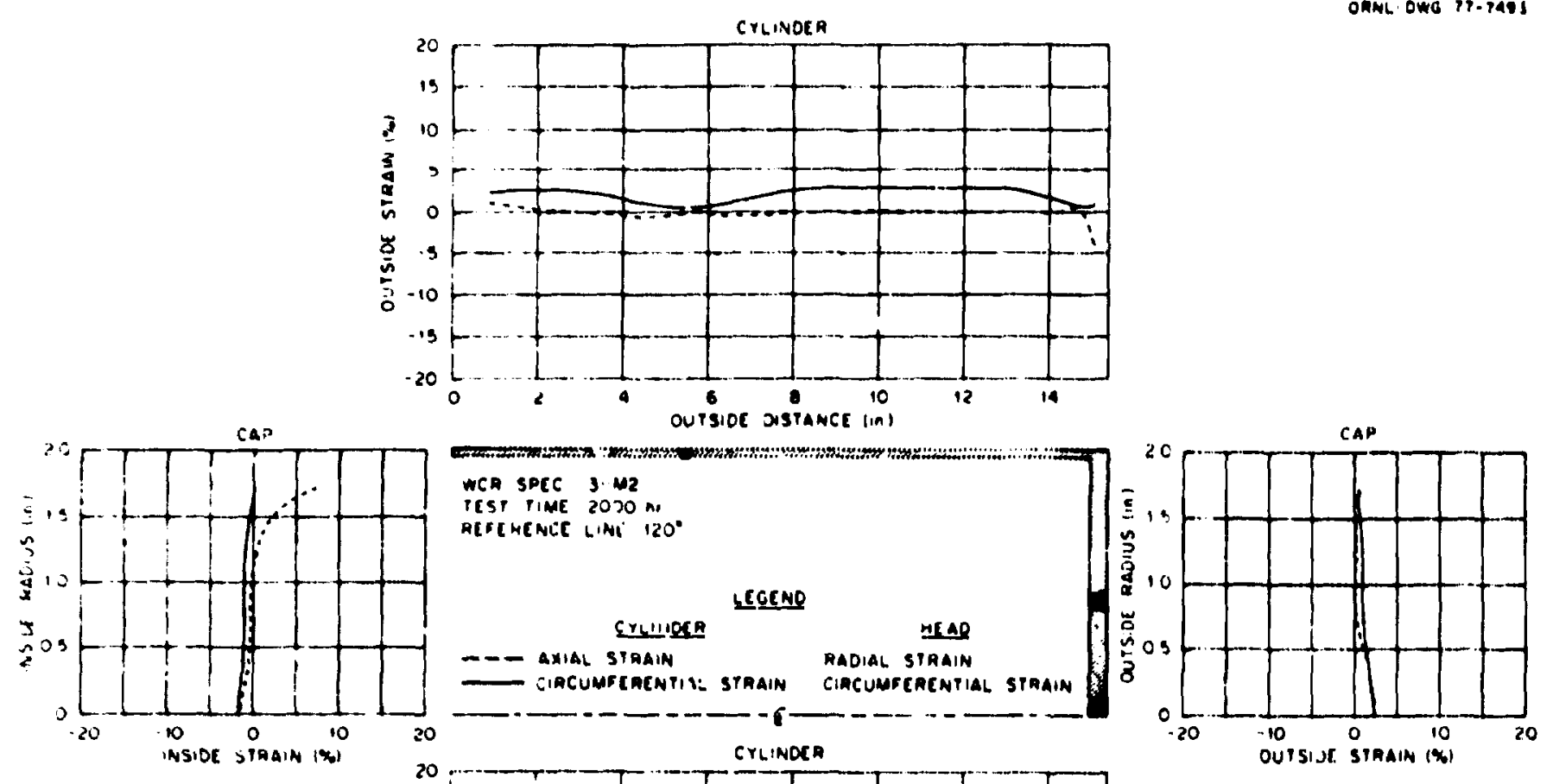

Fiz. Al2-c. Surface strain distrivuition for apecimen 3-M2 along the axial reference plane, $\theta=120^{\circ}$, at $2000 \mathrm{hr}(1 \mathrm{ln} .=2.54 \mathrm{~cm})$. 


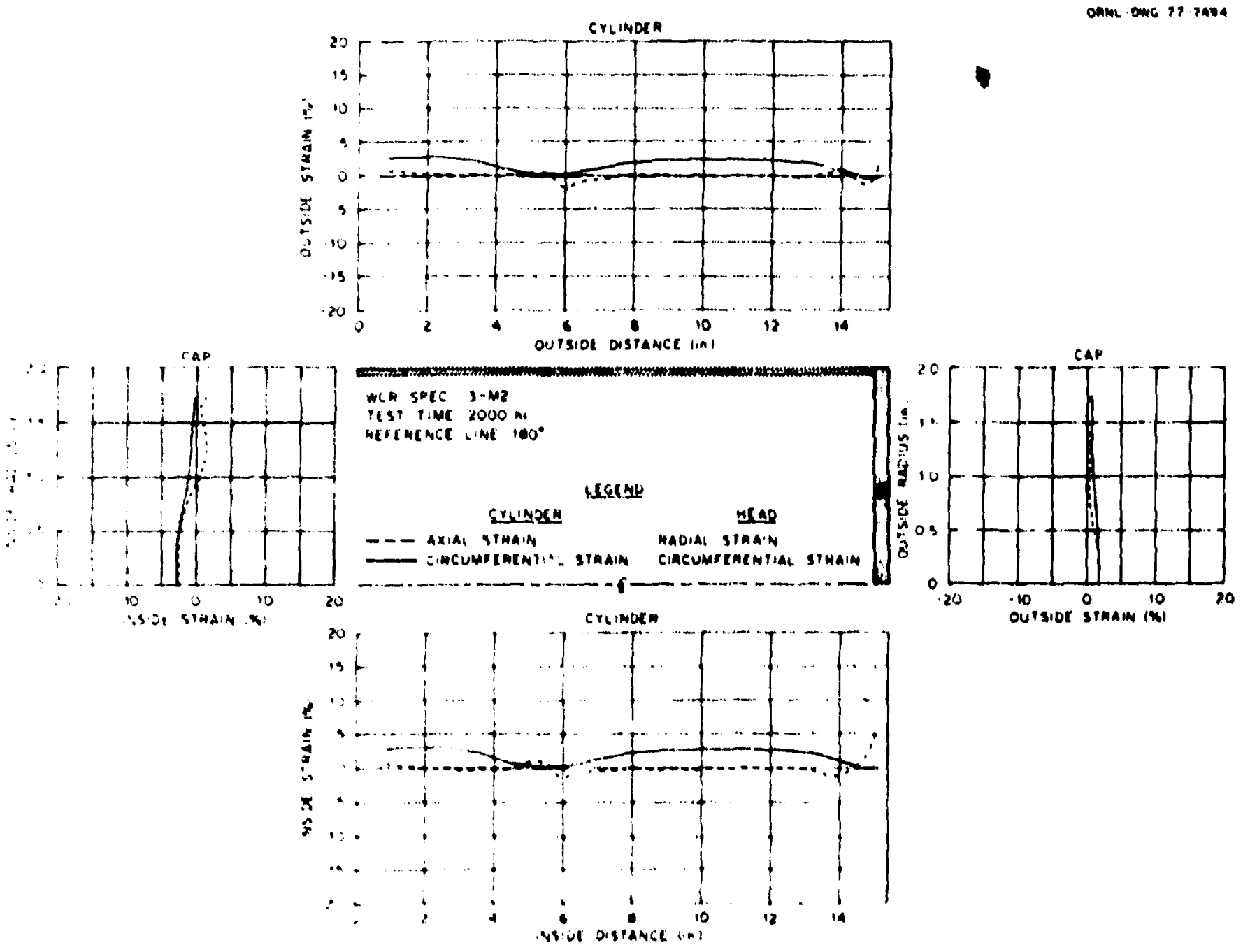

onme onc 11 rave

F18. Ali2nd. Surface otrain distribution for specimun 3-M2 along the reference plane, $0=180^{\circ}$, at $2000 \mathrm{hr}(1 \mathrm{ln} .-2.54 \mathrm{~cm})$. 

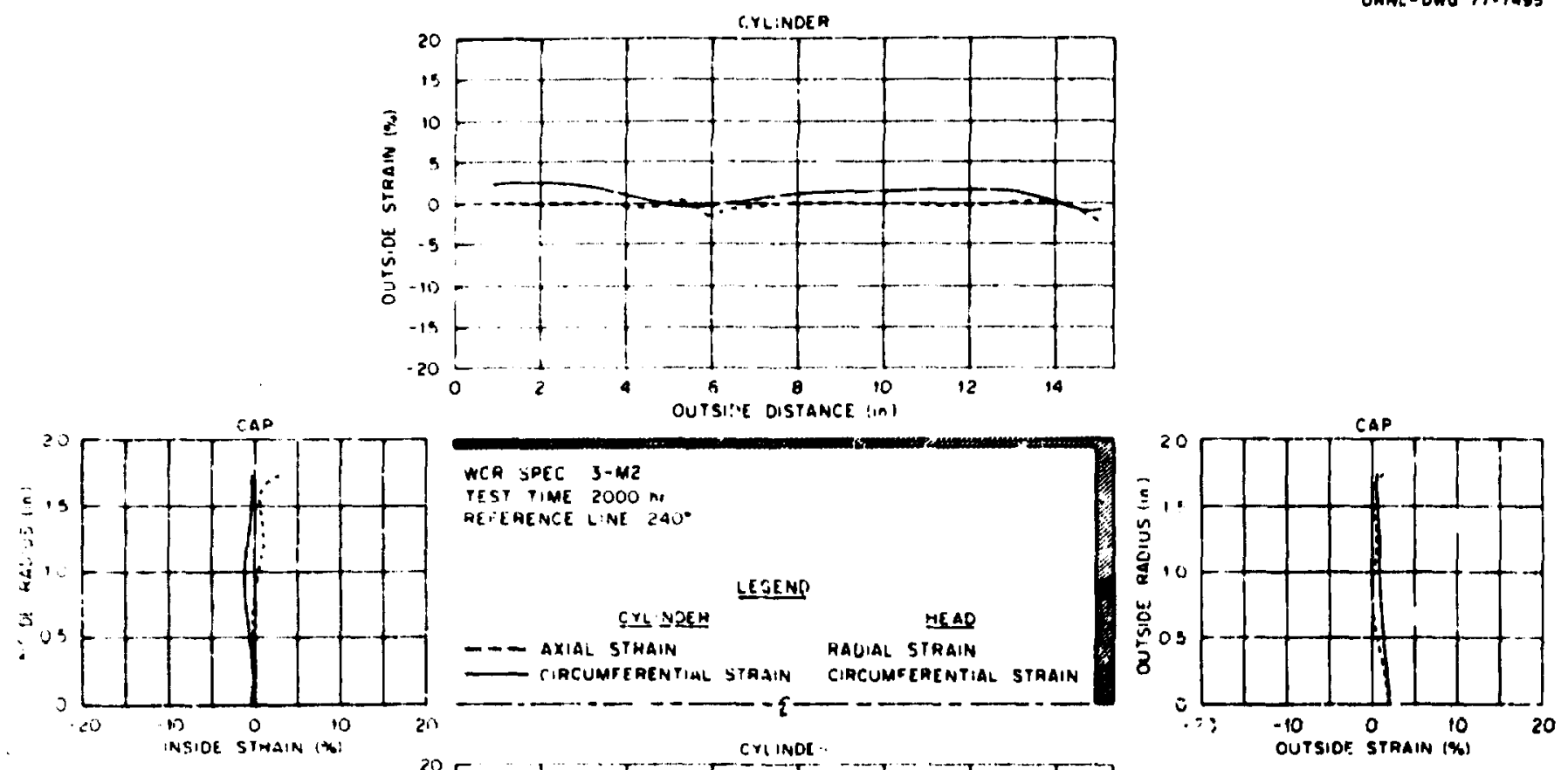

Fig. Al2-e. Surface strain distribution for specimen 3-M2 along the axial reference plane, $\theta=240^{\circ}$, at $2000 \mathrm{hr}(1 \mathrm{ln} .=2.54 \mathrm{~cm})$. 

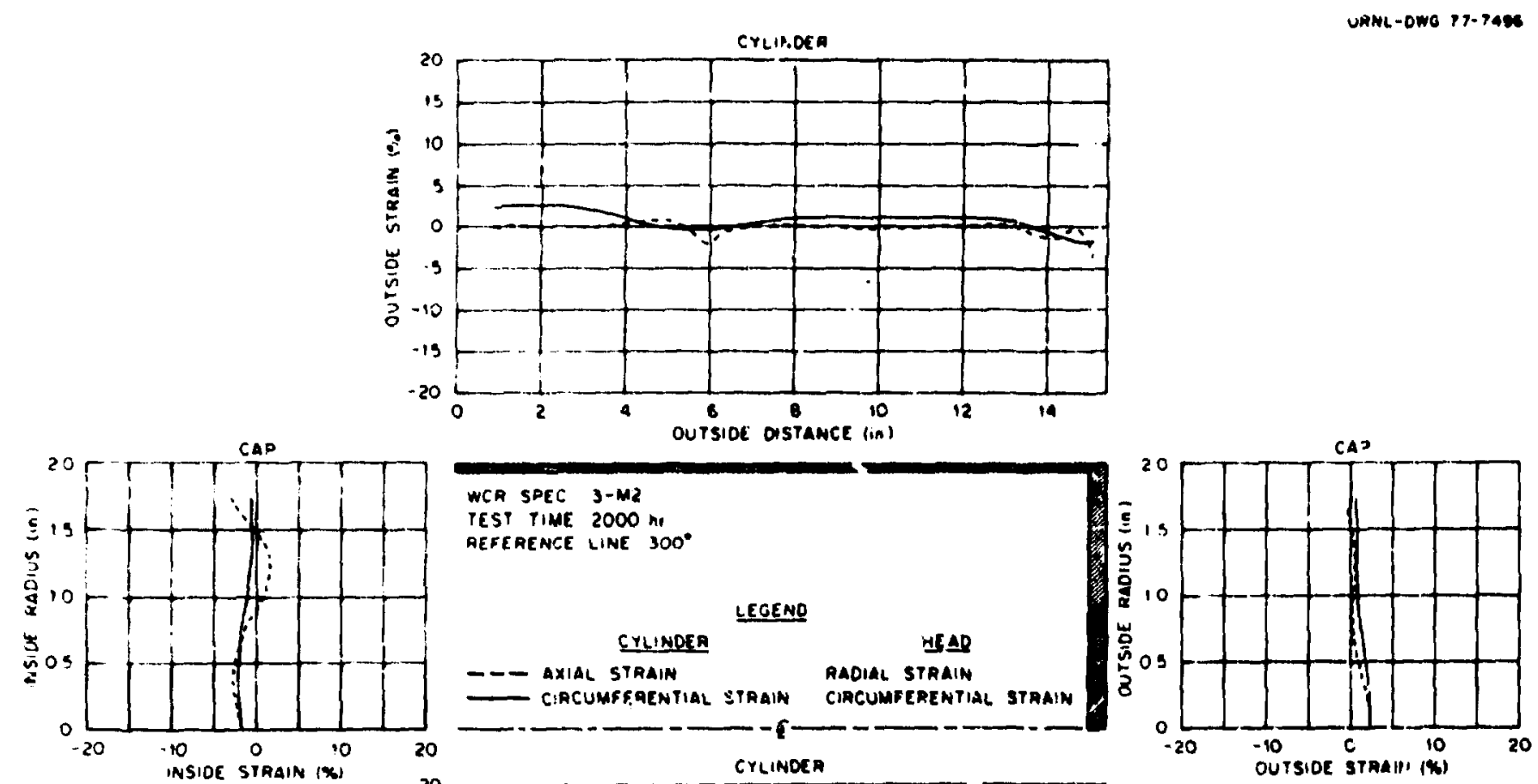

F1g. A12-f. Surface strain distribution for specimen 3-M2 along the axial reference plane, $\theta=300^{\circ}$, at $2000 \mathrm{hr}(1 \mathrm{ln} .=2.54 \mathrm{~cm}$ ). 

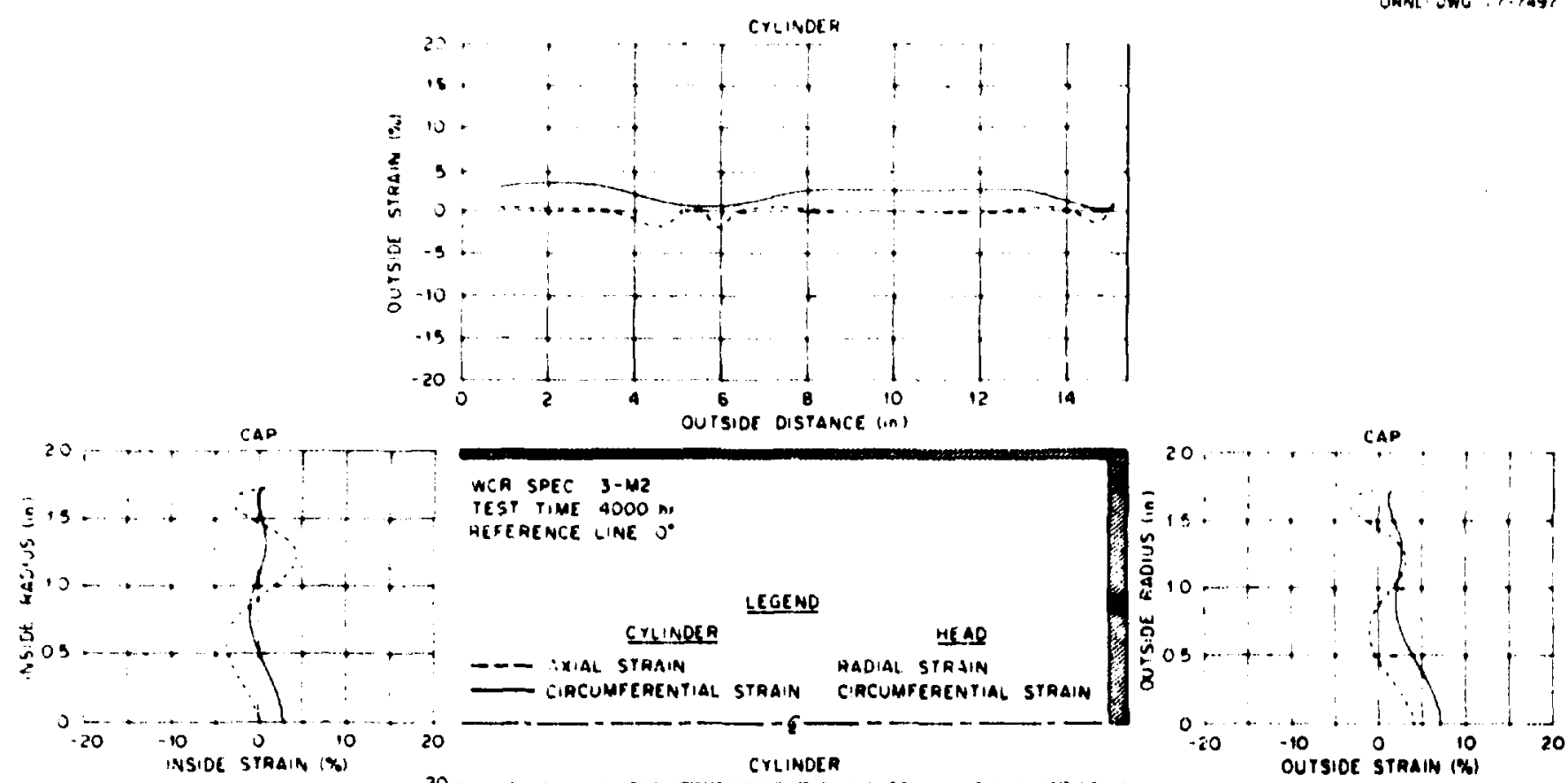

F1g. Al3-a. Surface strain distribution for specimen 3-M2 along the axial reference plane, $\theta=0^{\circ}$, at $4000 \mathrm{hr}(1 \mathrm{ln} .=2.54 \mathrm{~cm})$. 


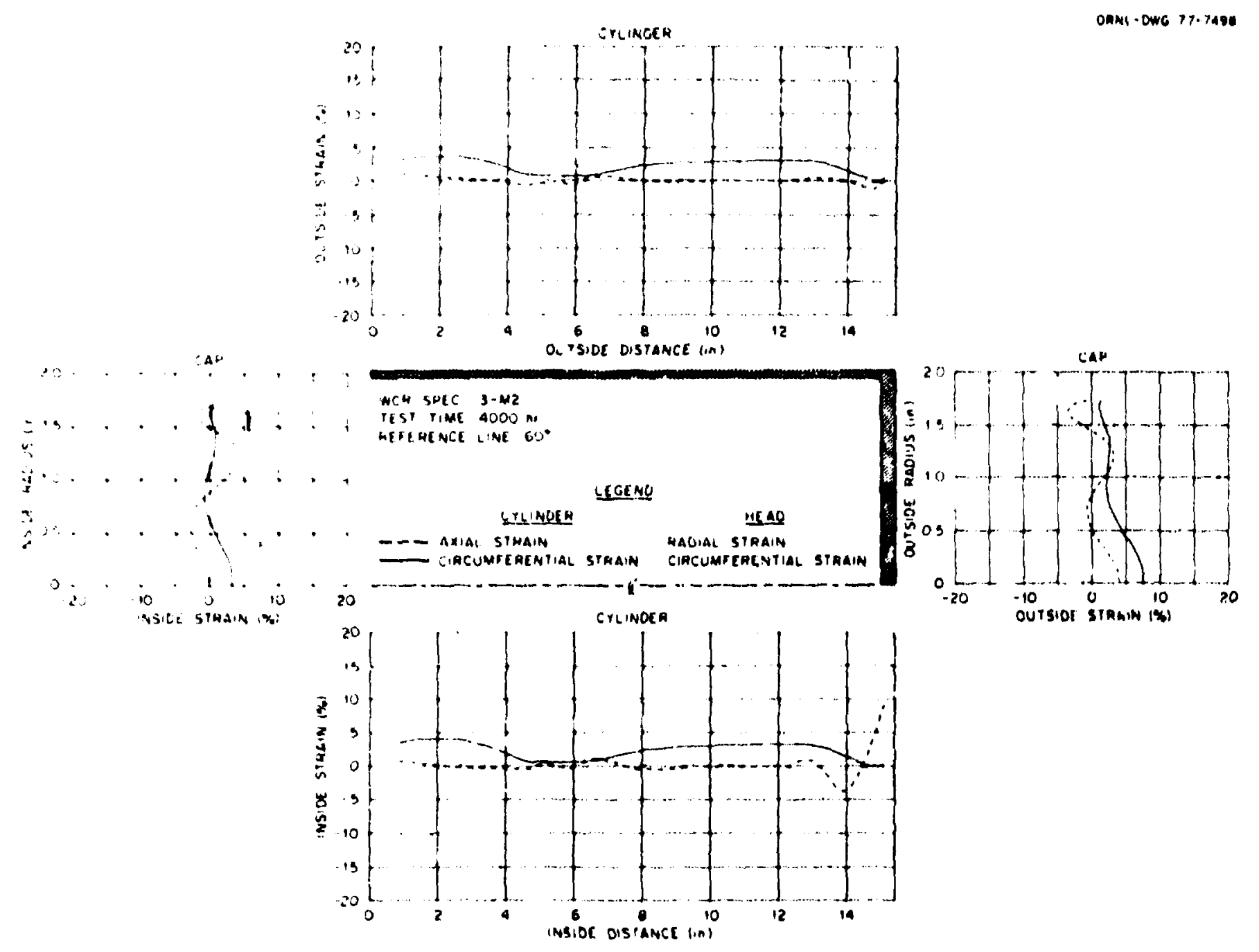

F18. Al3-b. Surface strain distribution for specimen 3-M2 along the axtal reference plane, $\theta=60^{\circ}$, at $4000 \mathrm{hr}(1 \mathrm{ln} .=2.54 \mathrm{~cm})$. 

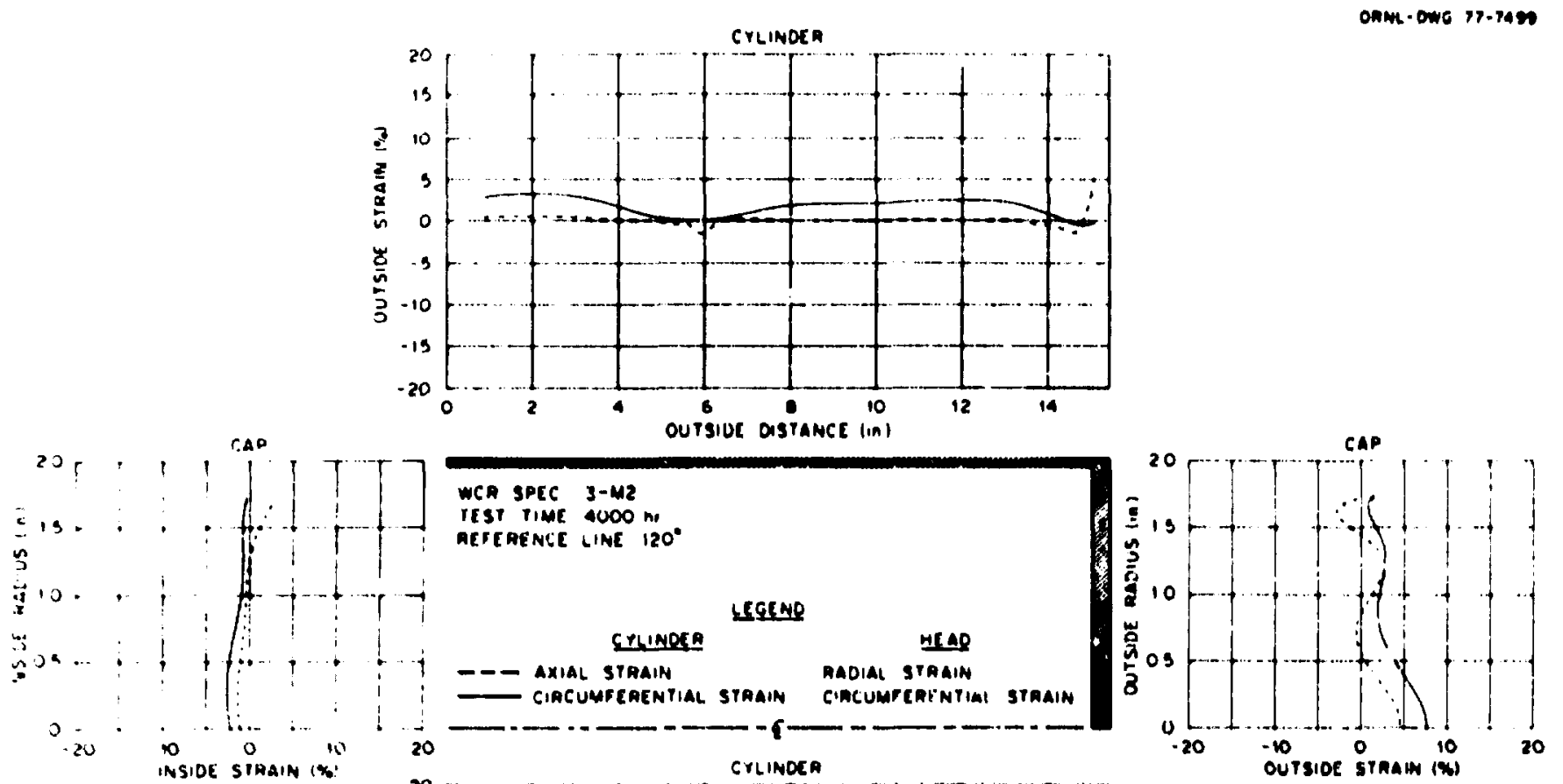

F18. Al3-c. Surface otrain distribution for spectinen 3-ke along the axial reference plane, $\theta=120^{\circ}$, at $4000 \mathrm{hr}$ (l in. $=2.54 \mathrm{~cm}$ ). 

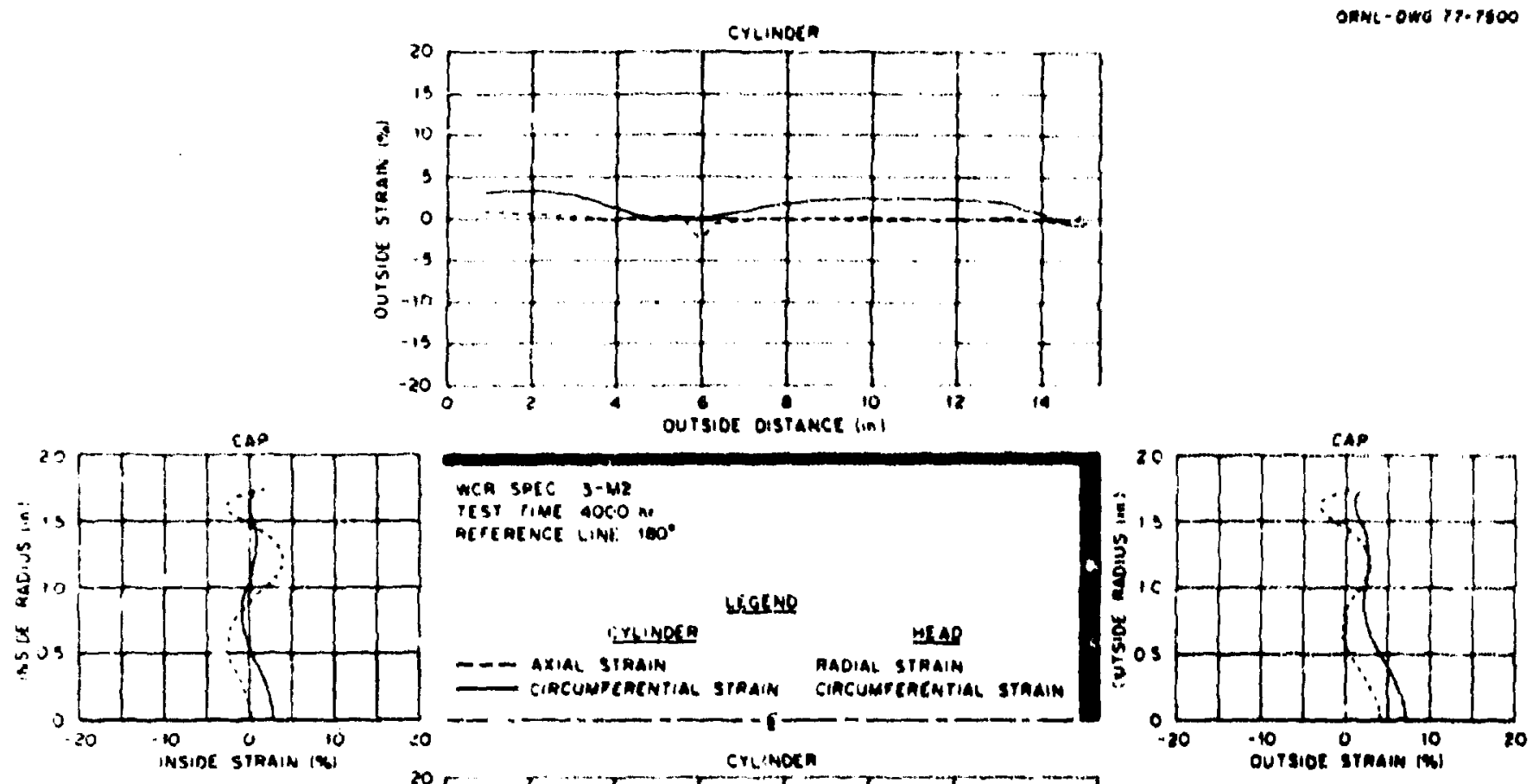

F1g. A13-d. Surface strain distribution for specimen 3-M2 lons the axtal reference plane, $\theta=180^{\circ}$, at $4000 \mathrm{hr}(+\mathrm{In} .=2.54 \mathrm{am}$ ). 

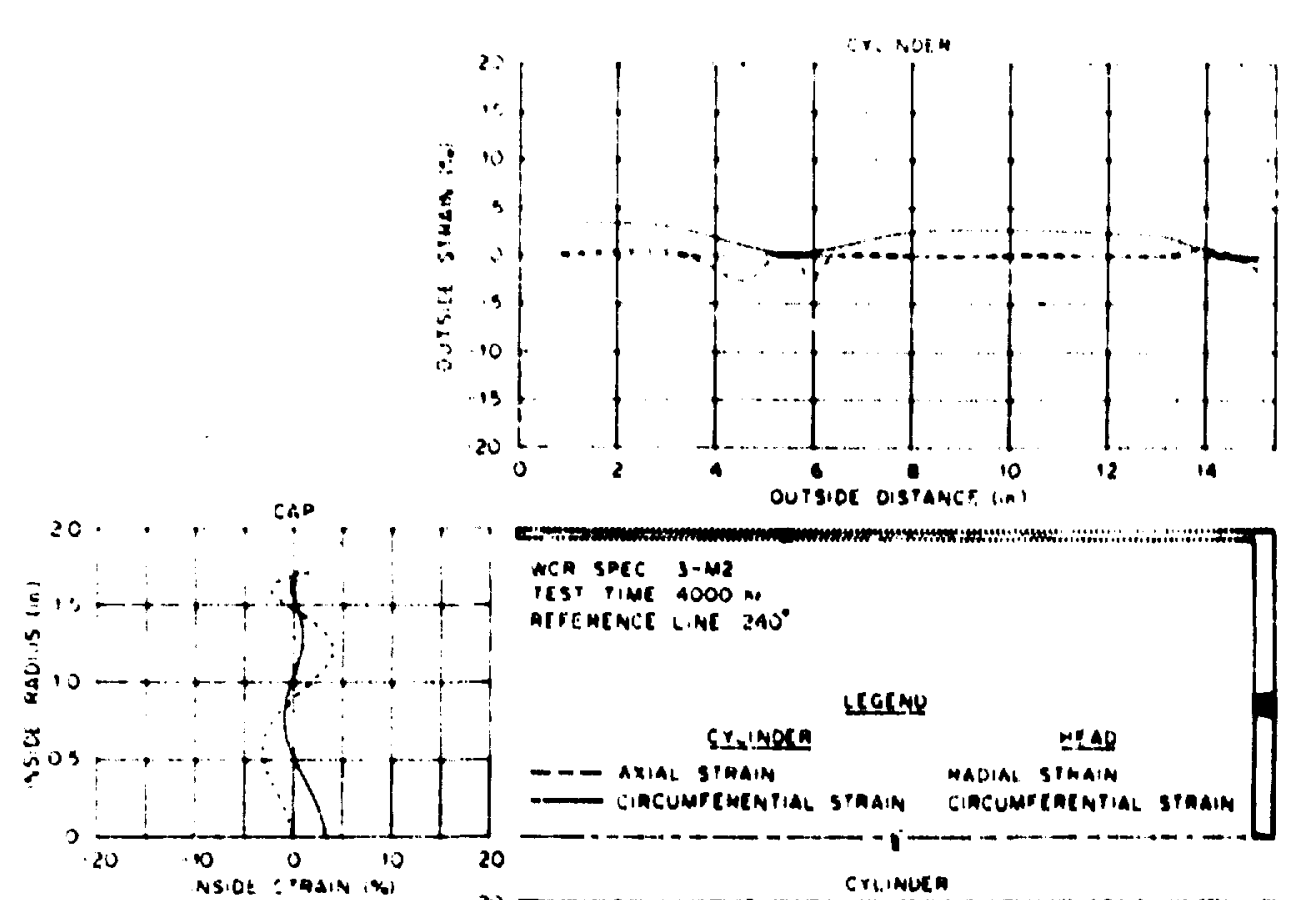

\section{HCA SPCC 3 - M2}

arrenENCE LINE zAO

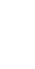

- - axial simain cincunarewential s STaAin
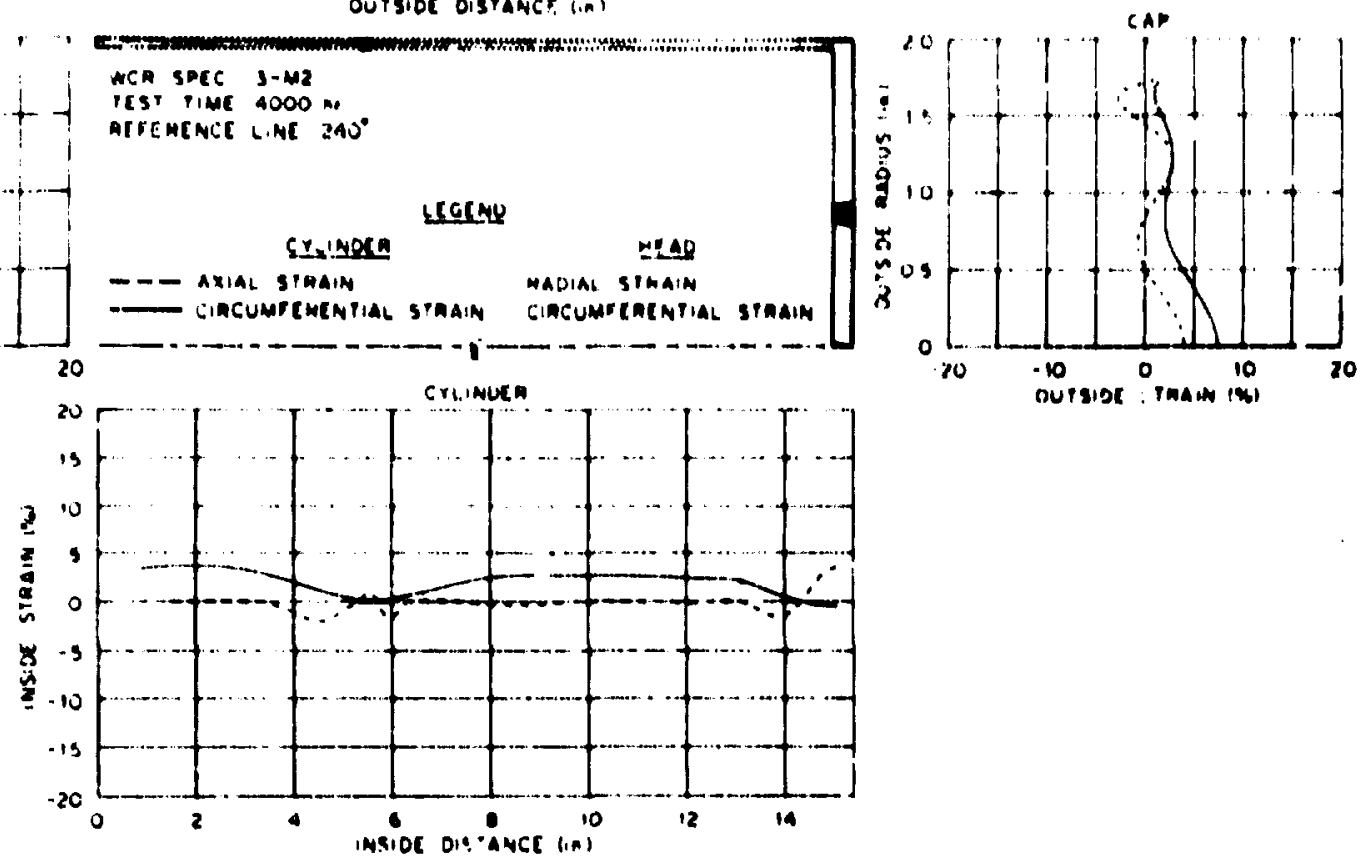

Fig. Al3-e. Surface atrain distribution for specimon 3-Me along the axial reference plane, $\theta=240^{\circ}$, at $4000 \mathrm{hr}$ (1 1n. $=2.54 \mathrm{~cm}$ ). 


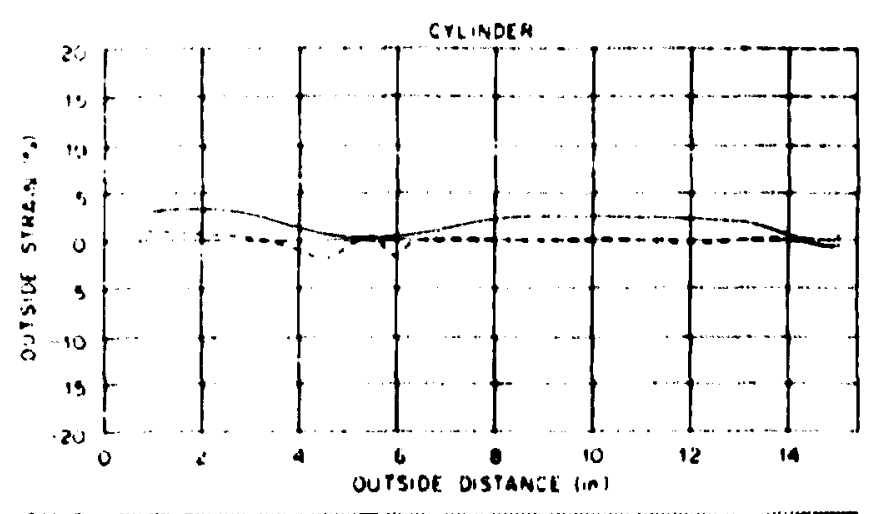

OMIA-DWG, $7-1102$

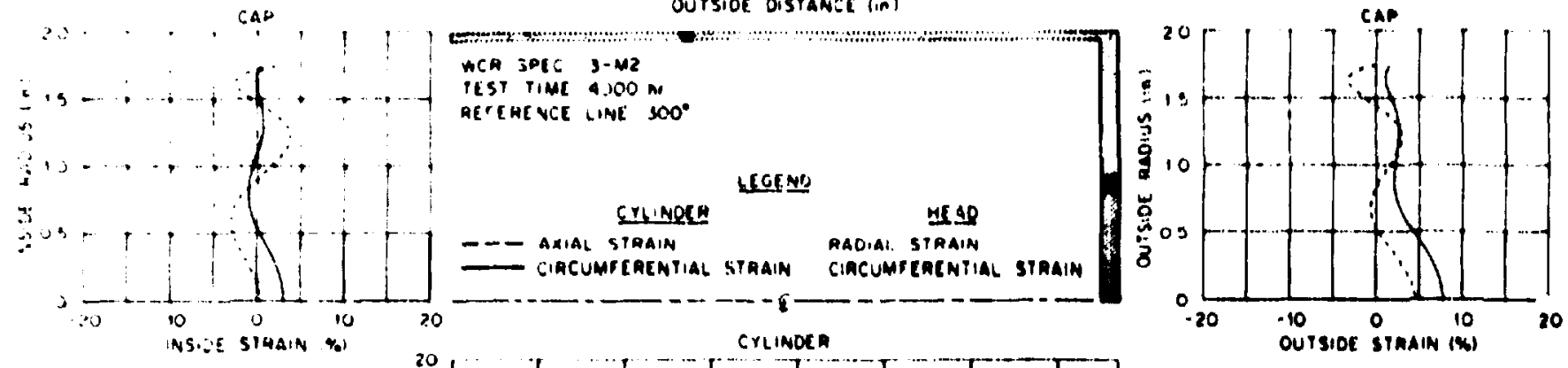

Fig. Al3-1. Surface strain distribution for specimen 3-M2 along the axial reference plane, $\theta=300^{\circ}$, at $4000 \mathrm{hr}(1 \mathrm{ln}$. $=2.54 \mathrm{~cm}$ ). 

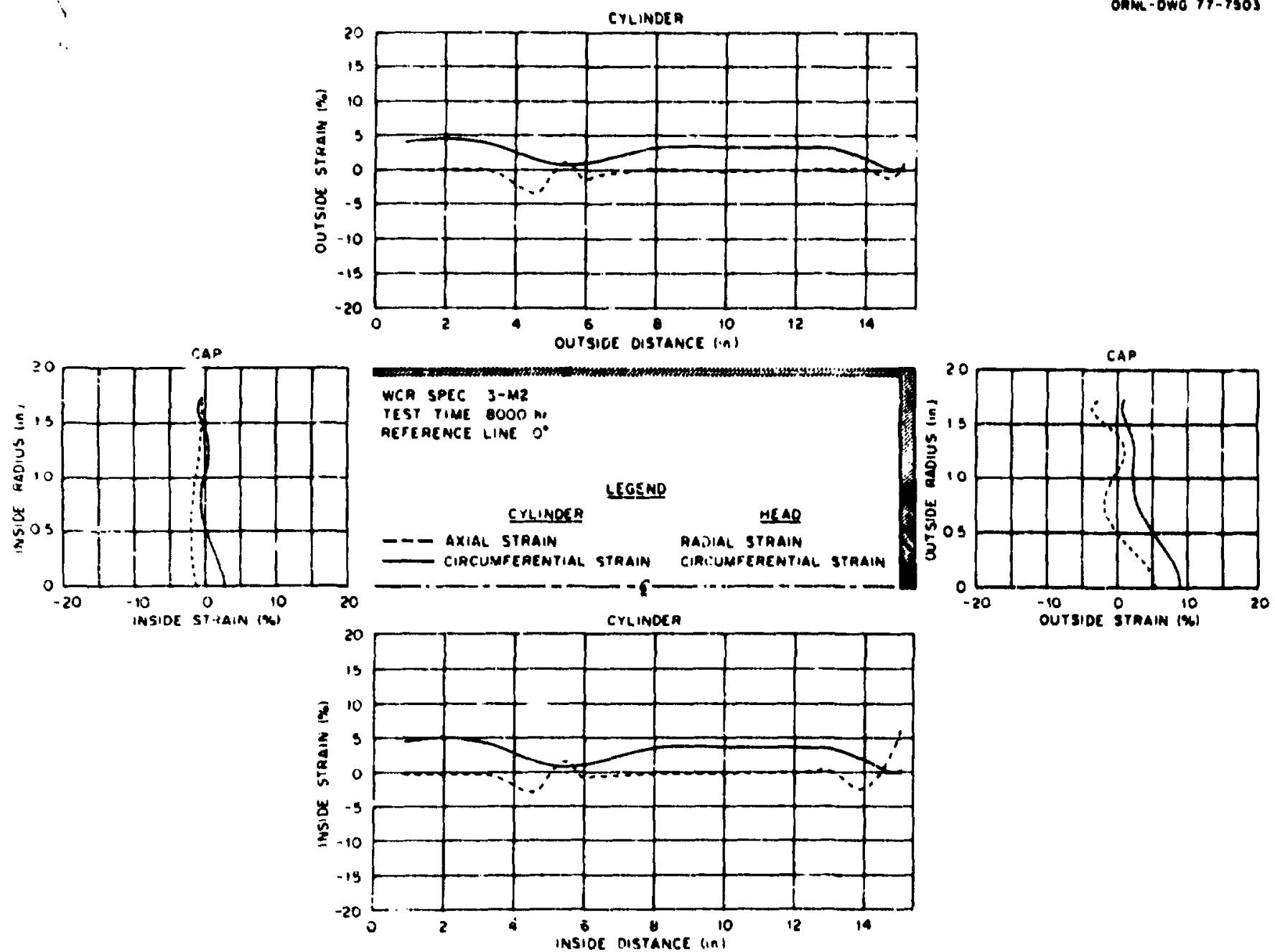

Fig. Al4-a. Surface strain distribution for specimen 3-M2 along the axial reference plane, $\theta=0^{\circ}$, at $8000 \mathrm{hr}(1 \mathrm{ln} .=2.54 \mathrm{~cm})$. 

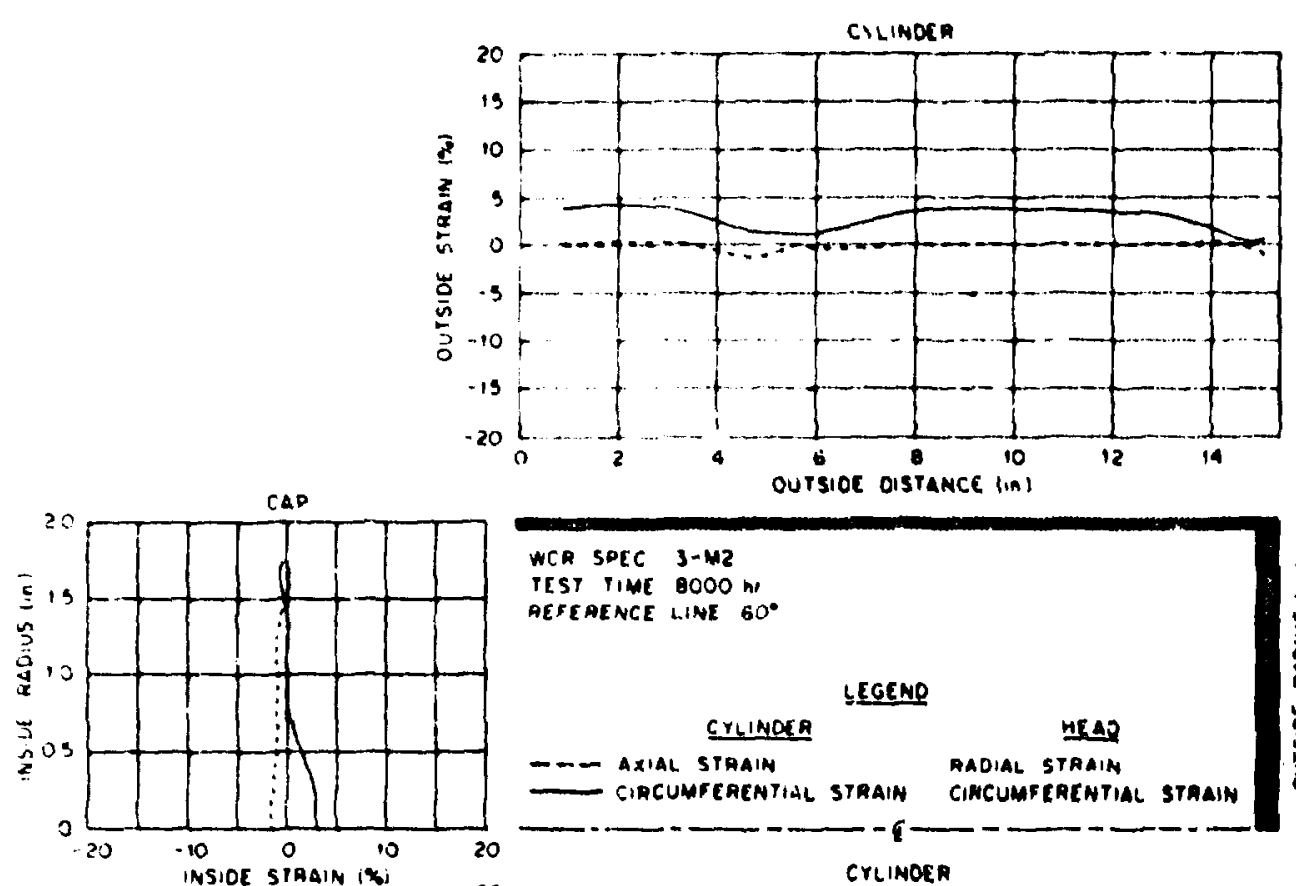
TEST TIME OOOO hI
AETEAENCE LINE $60^{\circ}$ AEFEAENCE LINE $60^{\circ}$
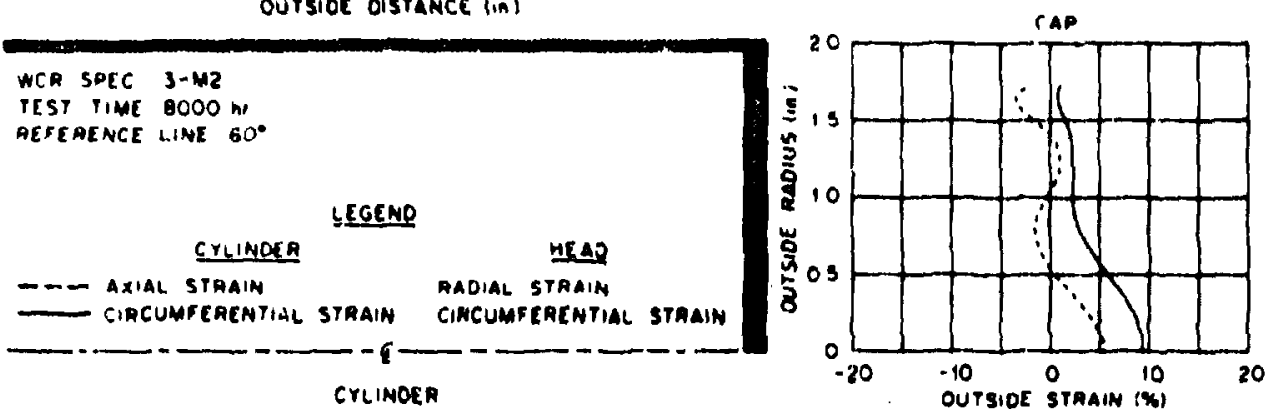

F18. A14-b. Surface strain distribution for specimen 3-M2 along the axial reference plane, $\theta=60^{\circ}$, at $8000 \mathrm{hr}(1 \mathrm{ln} .=2.54 \mathrm{~cm})$. 

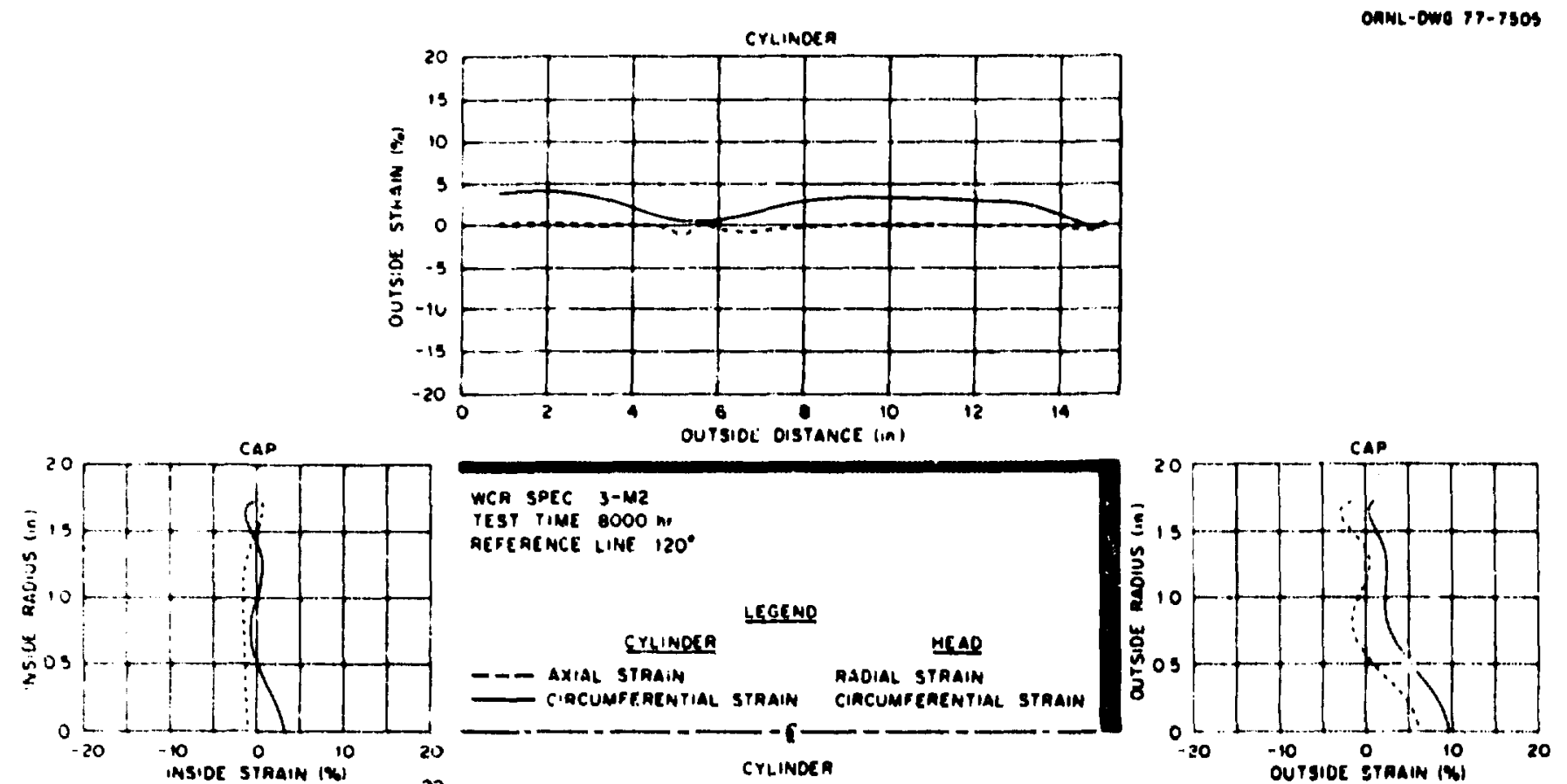

F1g. Al4-c. Surface strain distribution for specimen 3-M2 ulong the axial reference plane, $\theta=120^{\circ}$, at $8000 \mathrm{hr}$ (l in, $\left.=2.54 \mathrm{~cm}\right)$. 

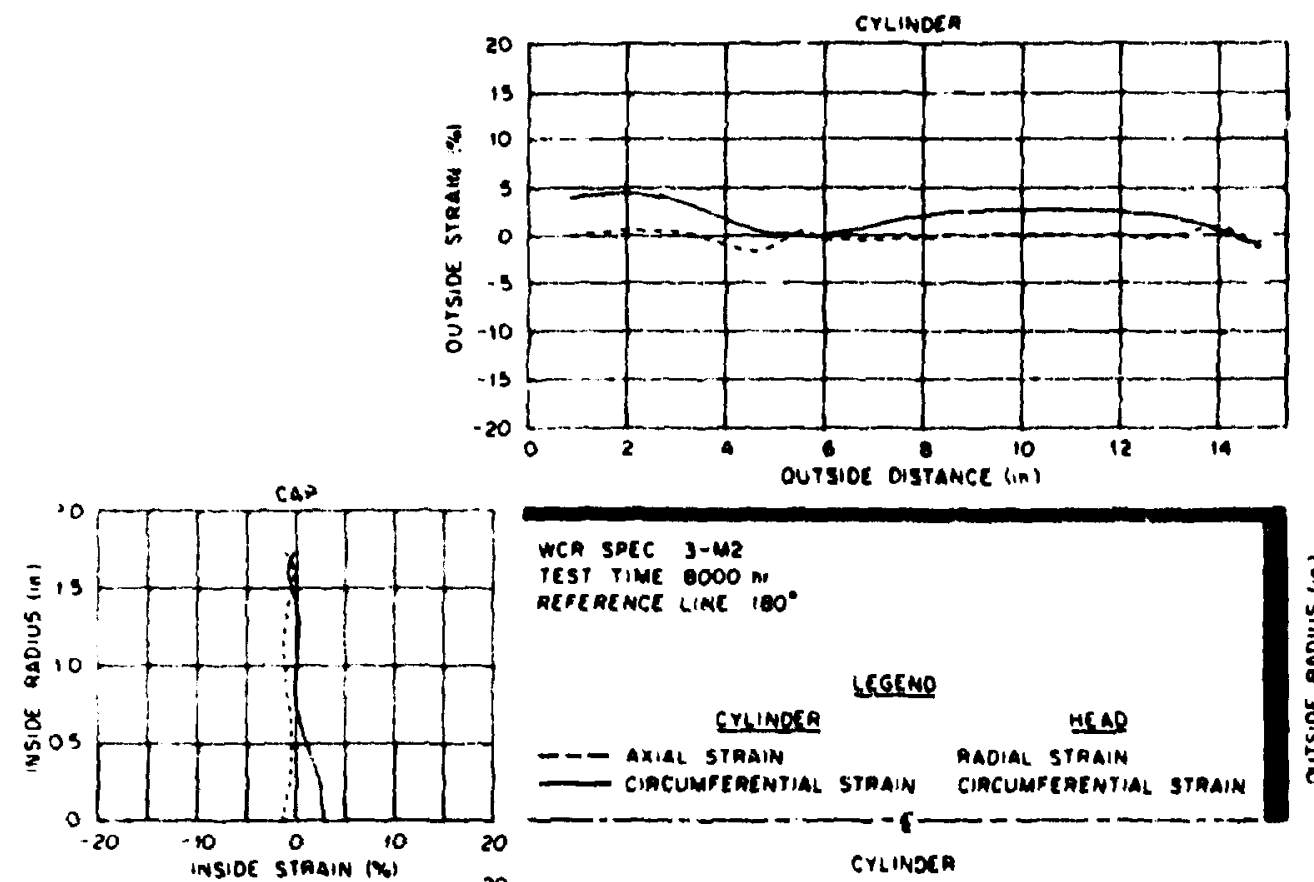

\section{WCA SPEC 3-42} TEST TINE 0000 M"
REFERENCE LINE 100

\section{EYIMOER \\ - - axial staAin \\ SGERO \\ ciacumfeachilal SThain}

HSAO
MAOIAL STAAIN

20

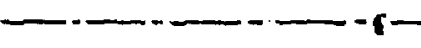

CIACUMFEAENTIAL STRAIN

CrLINOCA

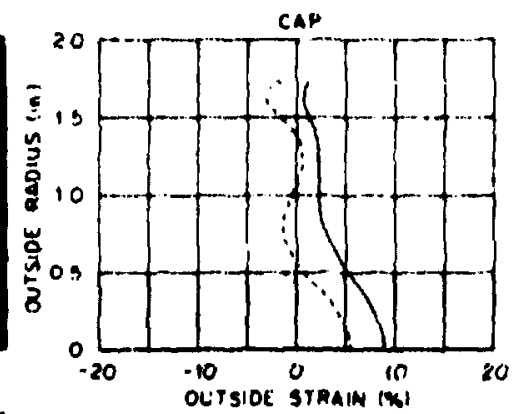

Fig. Al4-d. Surface strain distribution for apecimen 3-Me along the axial reference plane, $a=180^{\circ}$, at $8000 \mathrm{hr}(1 \mathrm{in} .=2.54 \mathrm{~cm}$ ). 

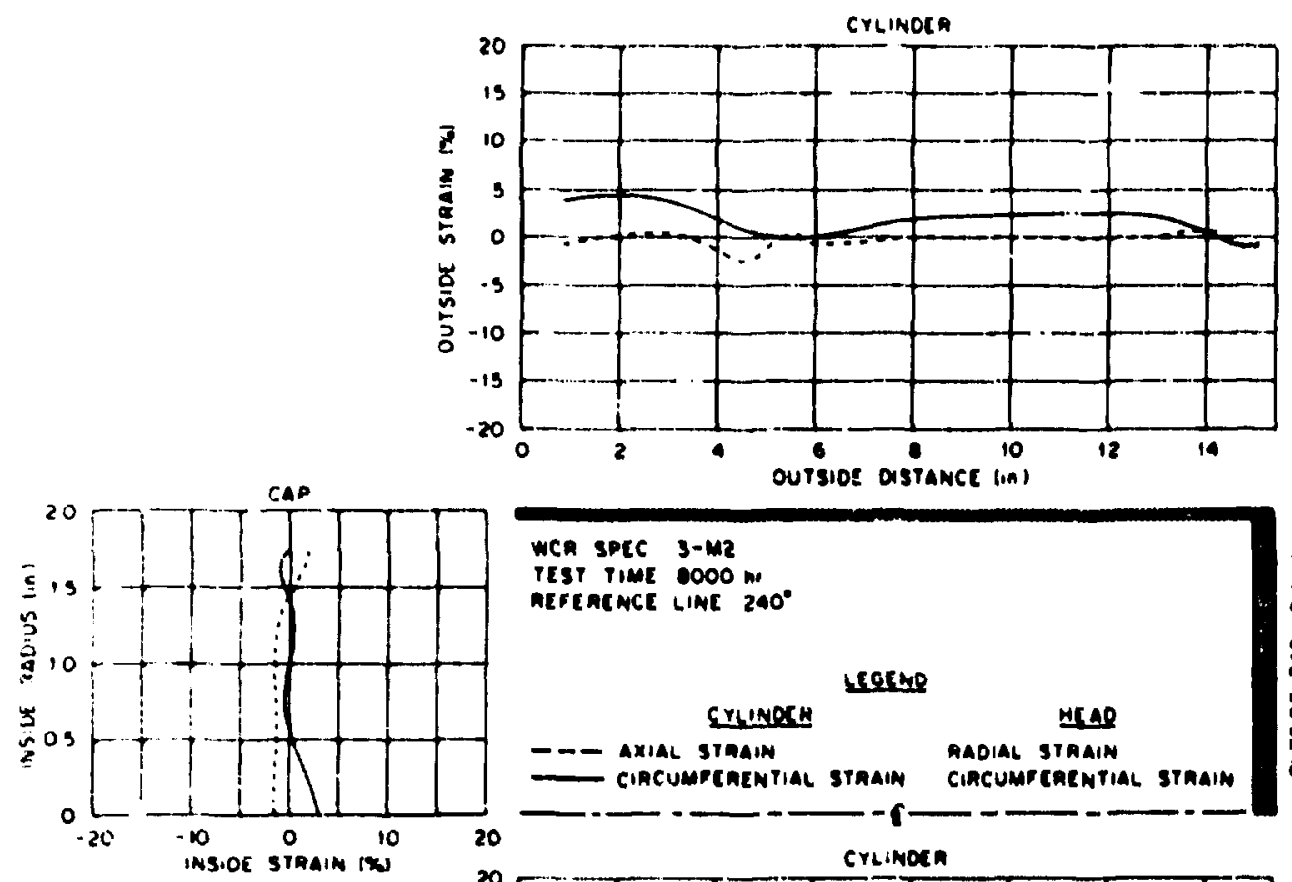

$$
\text { WCa SPEC } 3-\mathrm{Mr}
$$

TEST TIME $1000 \mathrm{ne}$

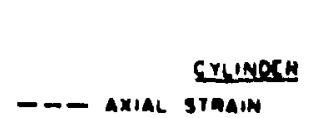

$\cos 40$

- Axial staAin

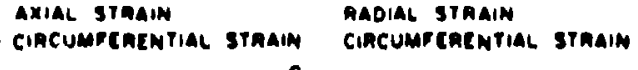

20
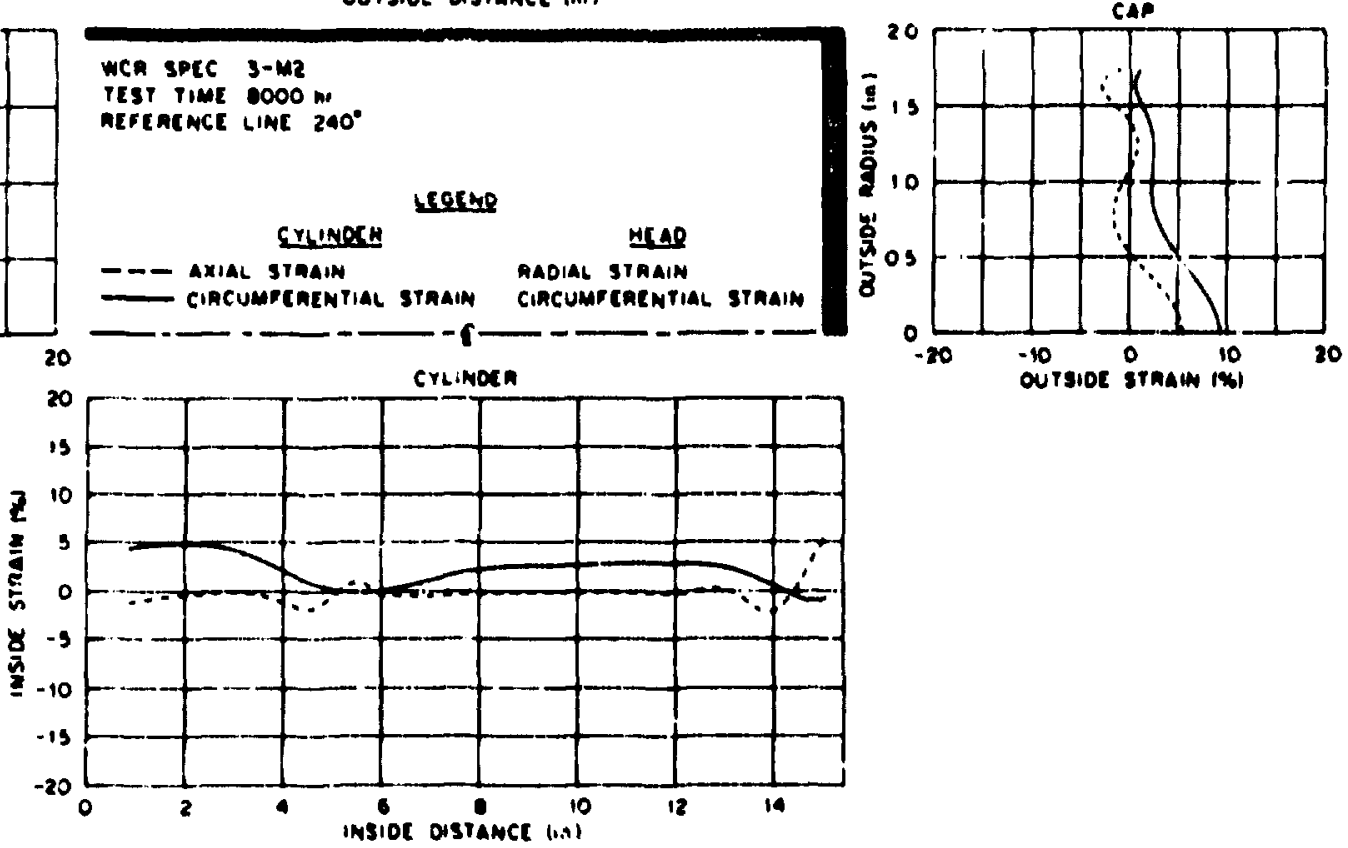

Fis. Al4-e. Surface stratn distribution for opecimen 3-M2 along the axtal reference plane, $\theta=248^{\circ}$, at $8000 \mathrm{hr}$ (1 in. $\pi: 2.54 \mathrm{~cm}$ ). 

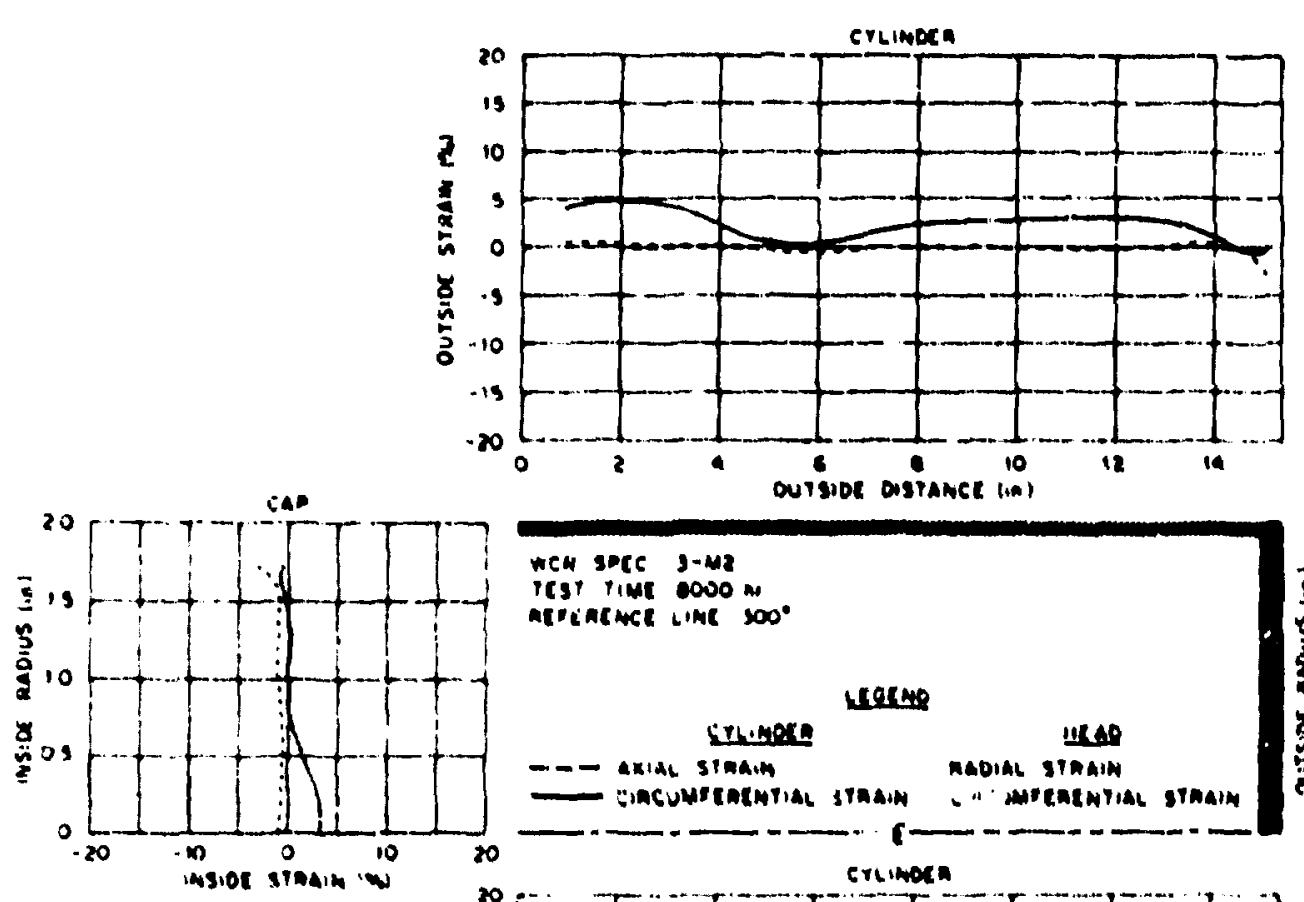

$$
\text { wen sace } 3-42
$$
atrincence Lime $500^{\circ}$
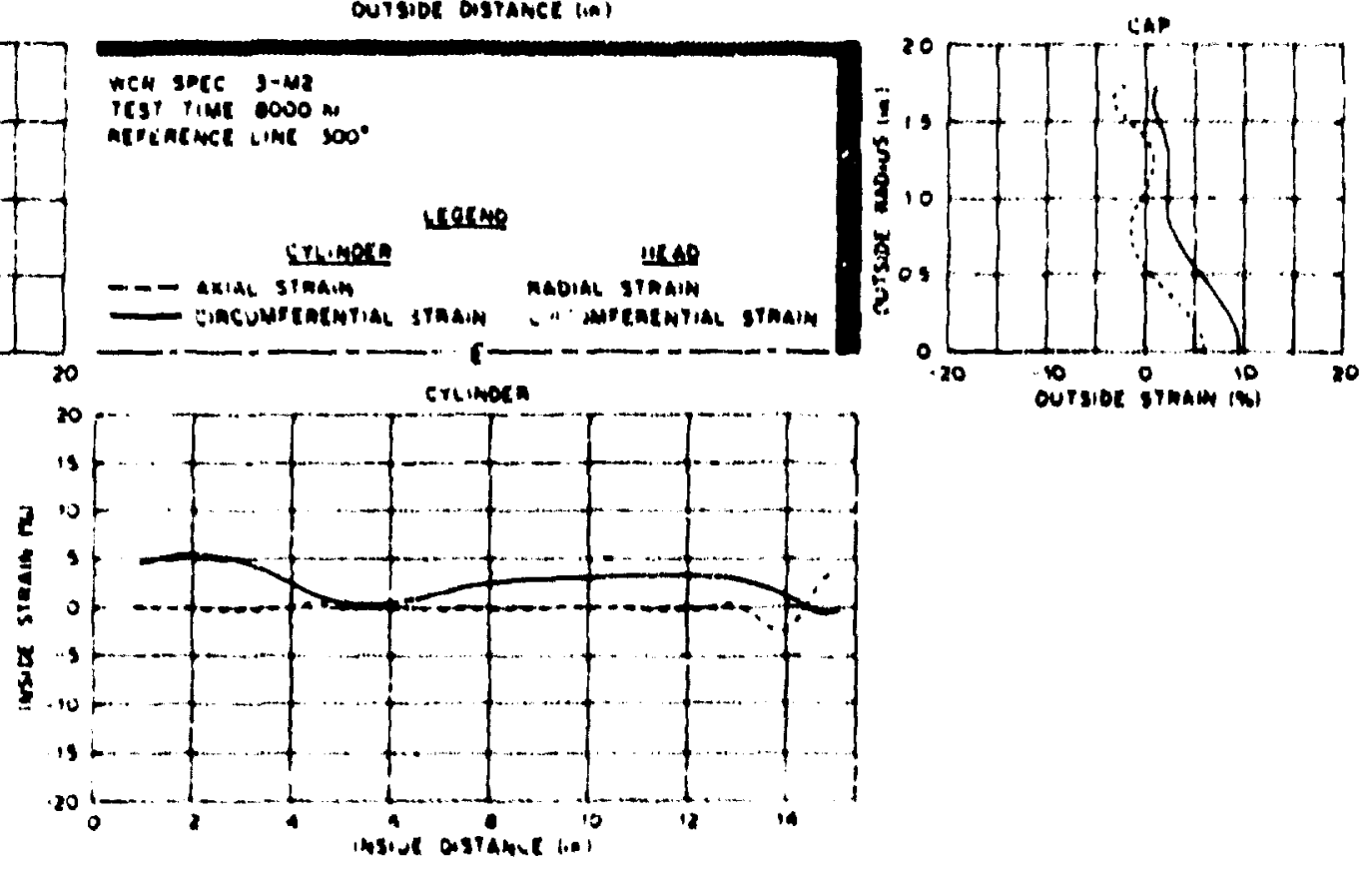

F1.8. Al4-5. Surface atrain diatribution for apecimen 3-Me alons the axial reference plane, $\theta=300^{\circ}$, at $\$ 000 \mathrm{hr}(2 \mathrm{ln} .=2.54 \mathrm{~cm})$. 

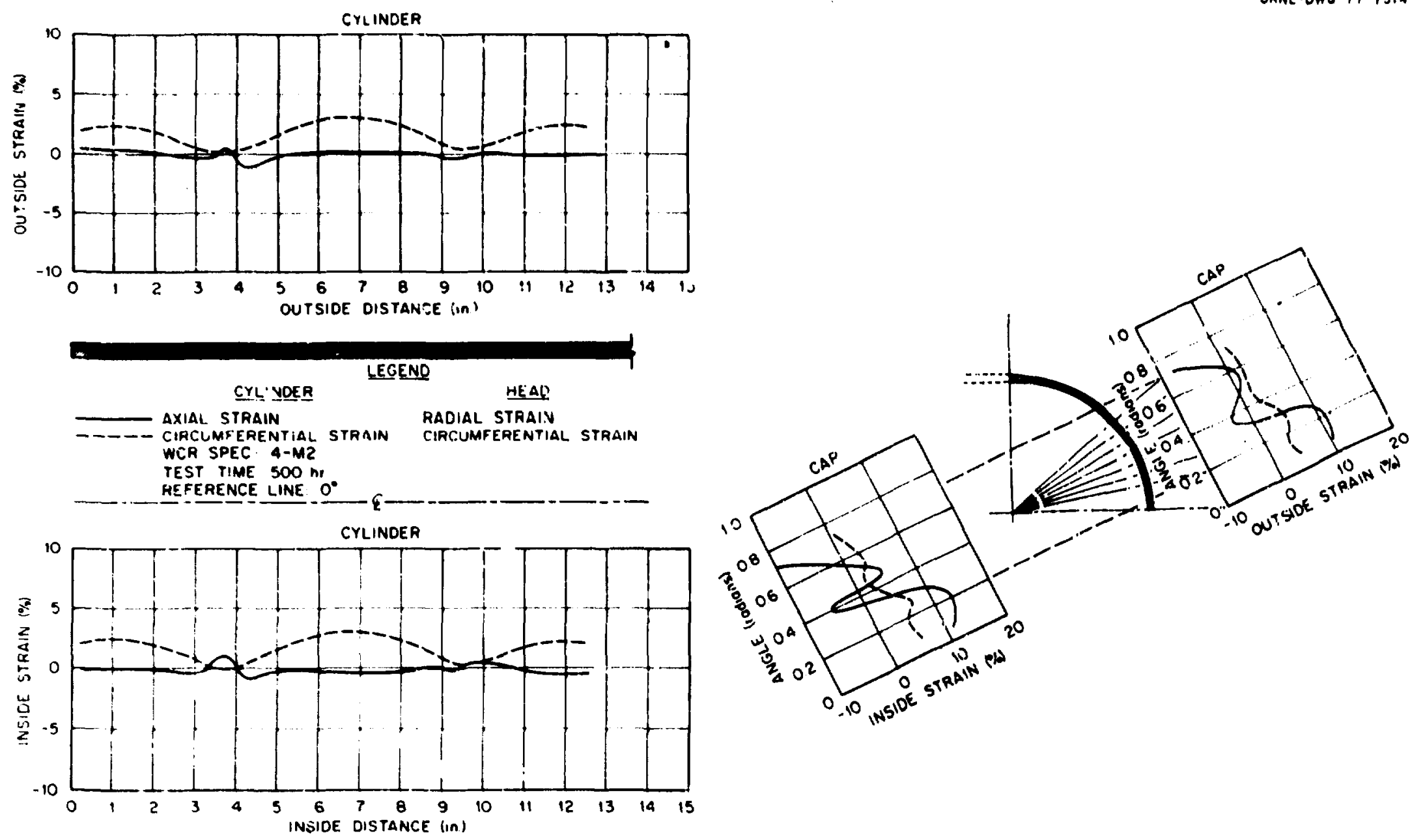

F1g. 5. 5-a. Surface strain distribution for specimen 4-M? elong the axtal reference plane, $\theta=0^{\circ}$, at $500 \mathrm{hr}(1 \mathrm{in} .=2.54 \mathrm{~cm})$. 

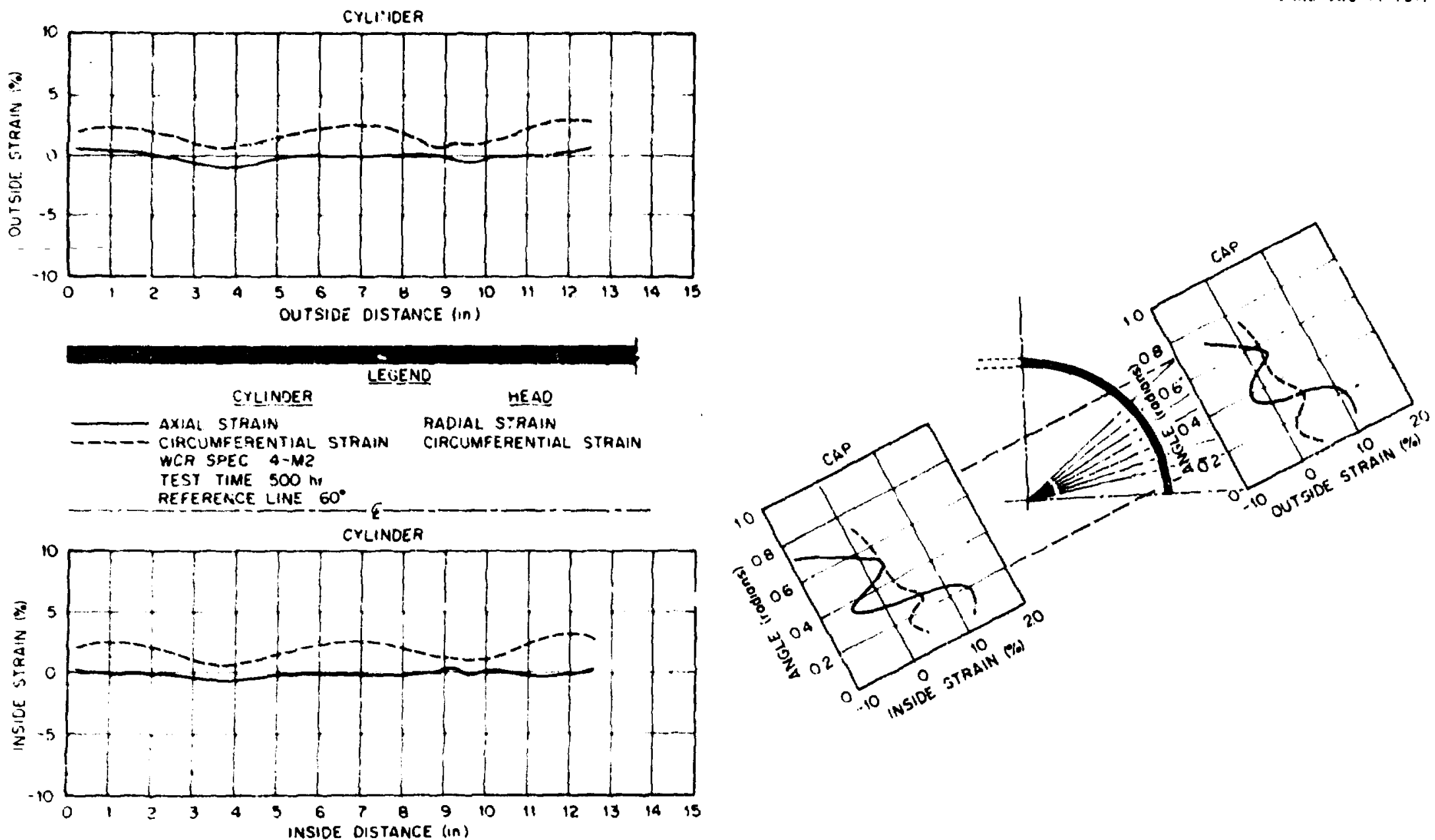

Fig. Al5-b. Surface strain aistribution for specimen 4-Me along the axicil reference plane, $\theta=60^{\circ}$, at $500 \mathrm{hr}(1 \mathrm{in} .=2.54 \mathrm{~cm})$. 

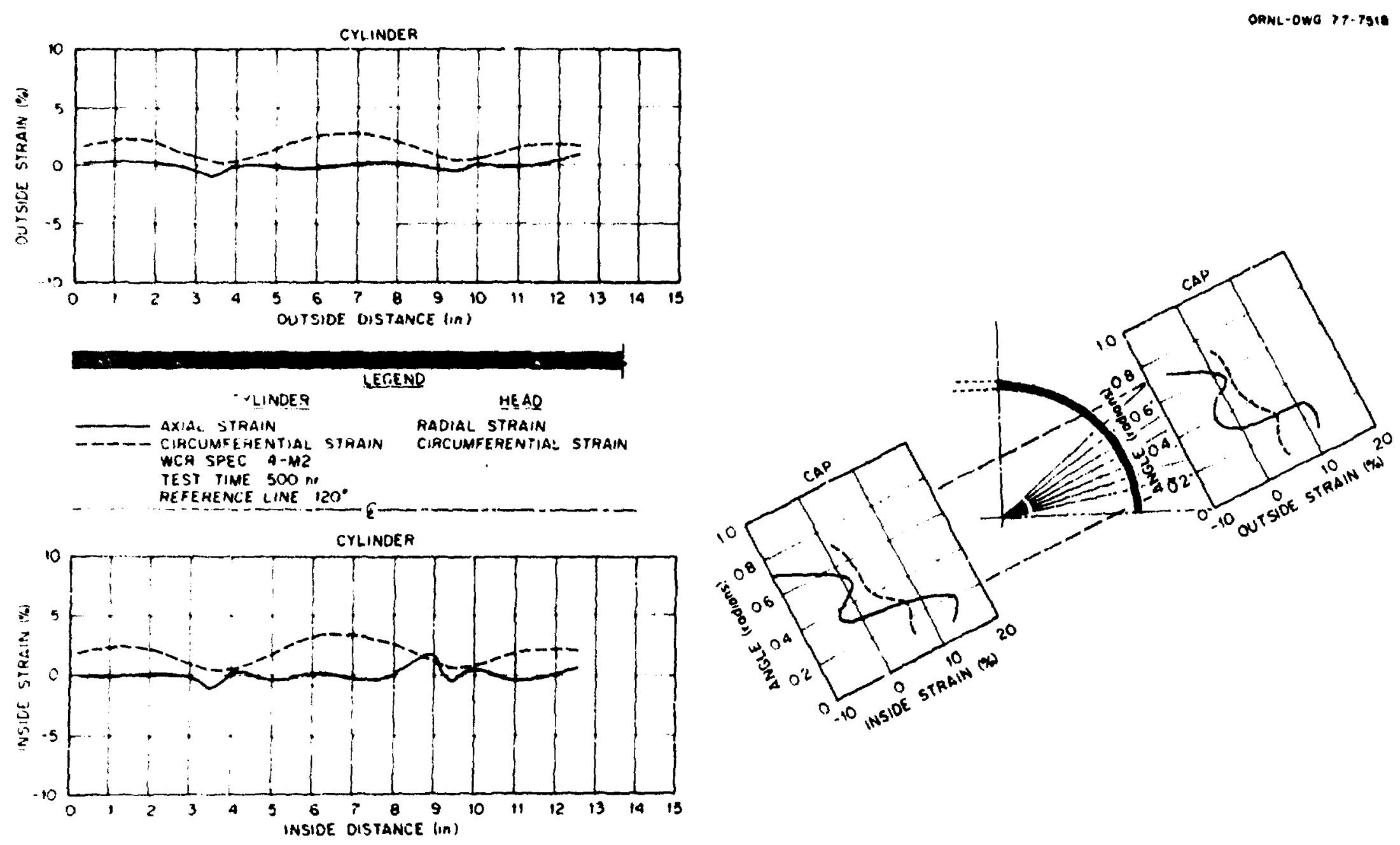

F18. Al5-c. Surface strain distribution for specimen 4-Me along the axtal reference plane, $\theta=120^{\circ}$, at $500 \mathrm{hr}\left(11::^{\circ}=2.54 \mathrm{~cm}\right)$. 

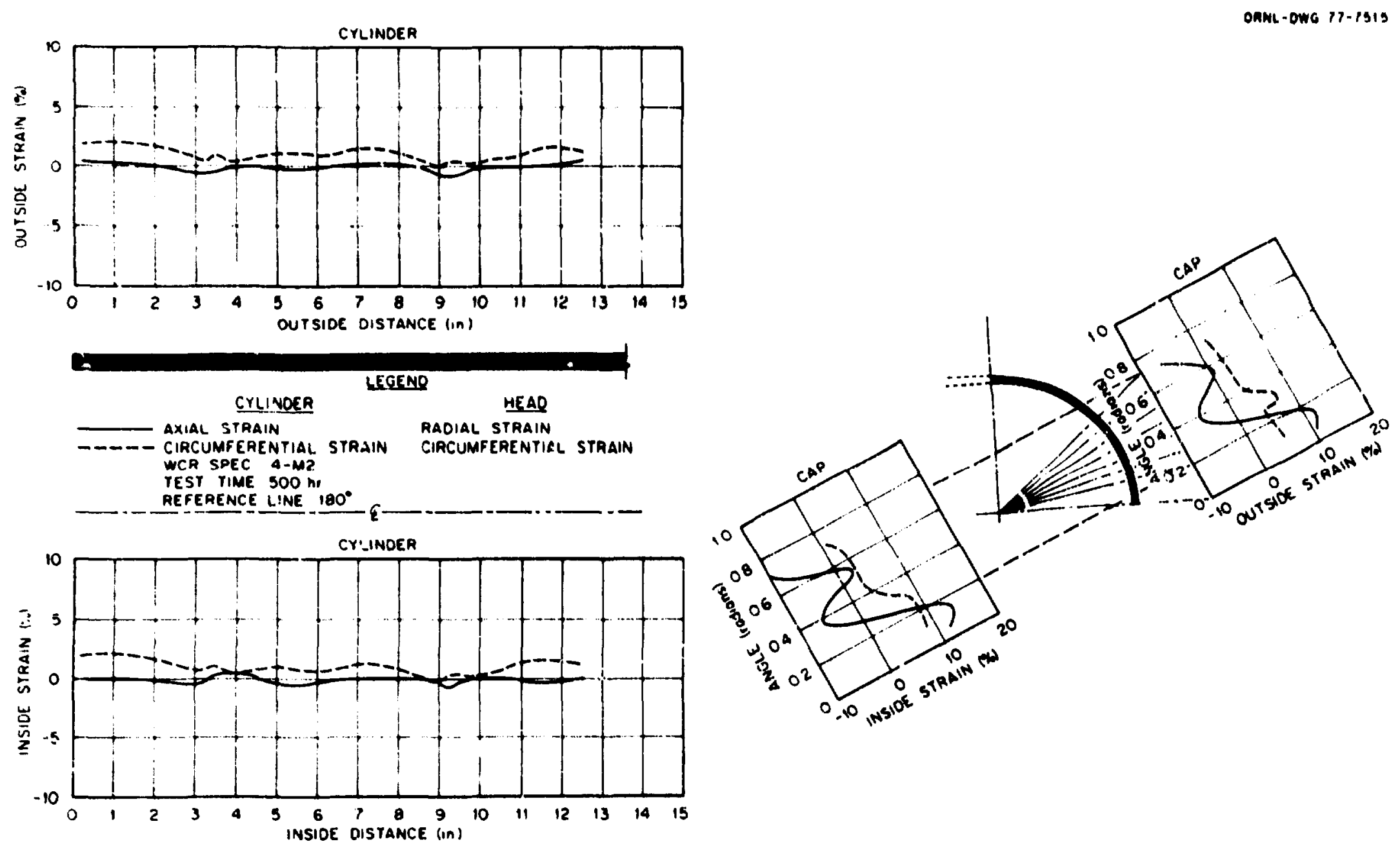

F18. Al5-d. Surface struin distribution for specimen 4-M2 along the axisl rererence plane, $\theta=180^{\circ}$, at $500 \mathrm{hr}(1 \mathrm{ln}$. $=2.54 \mathrm{~cm})$. 

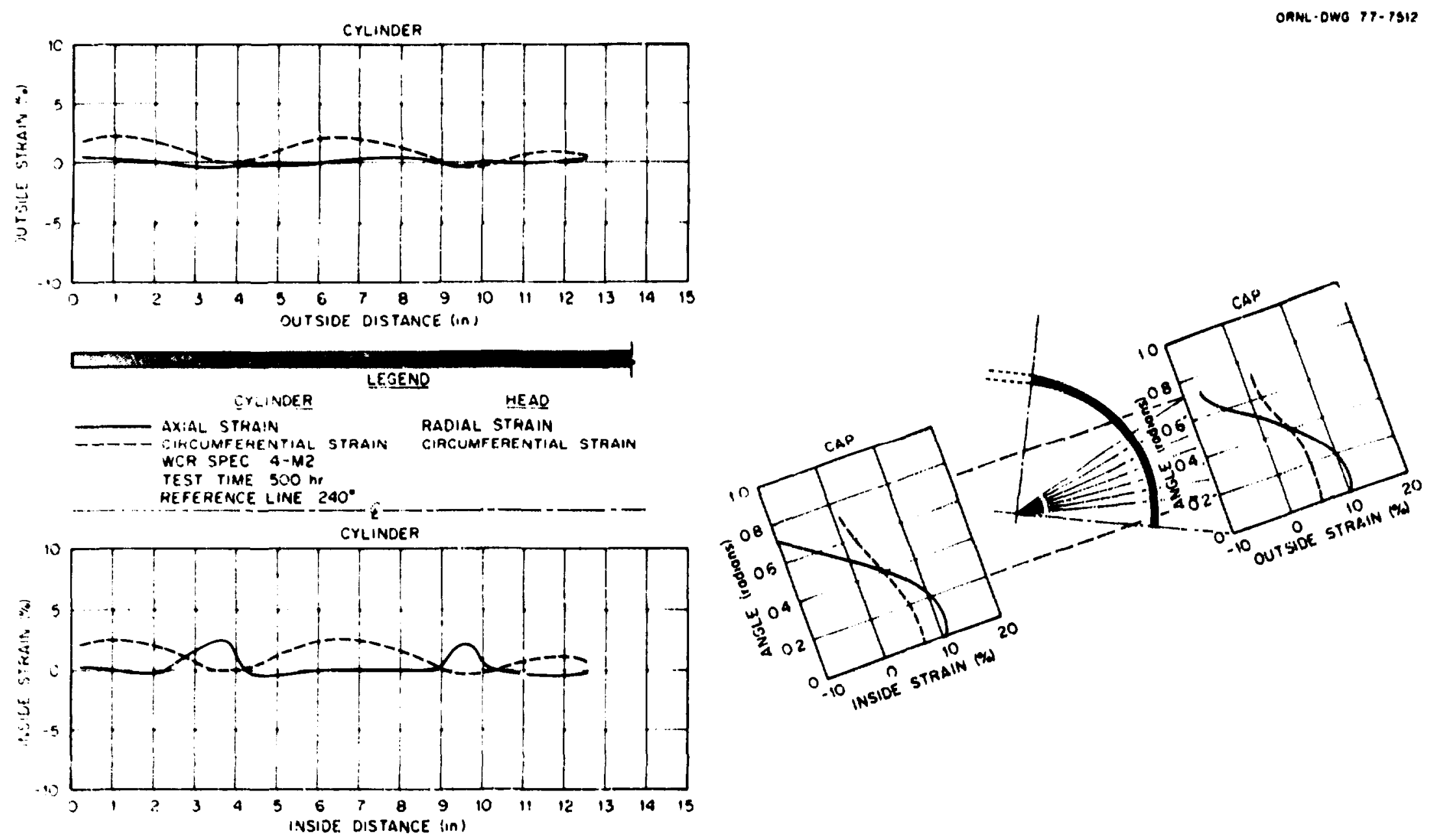

Fig. Al5-e. Surface -train distribution for specimen 4-M2 a long the axial reference plane, $\theta=240^{\circ}$, at $500 \mathrm{hr}$ ( $1 \mathrm{in}$. $=2.54 \mathrm{~cm}$ ). 

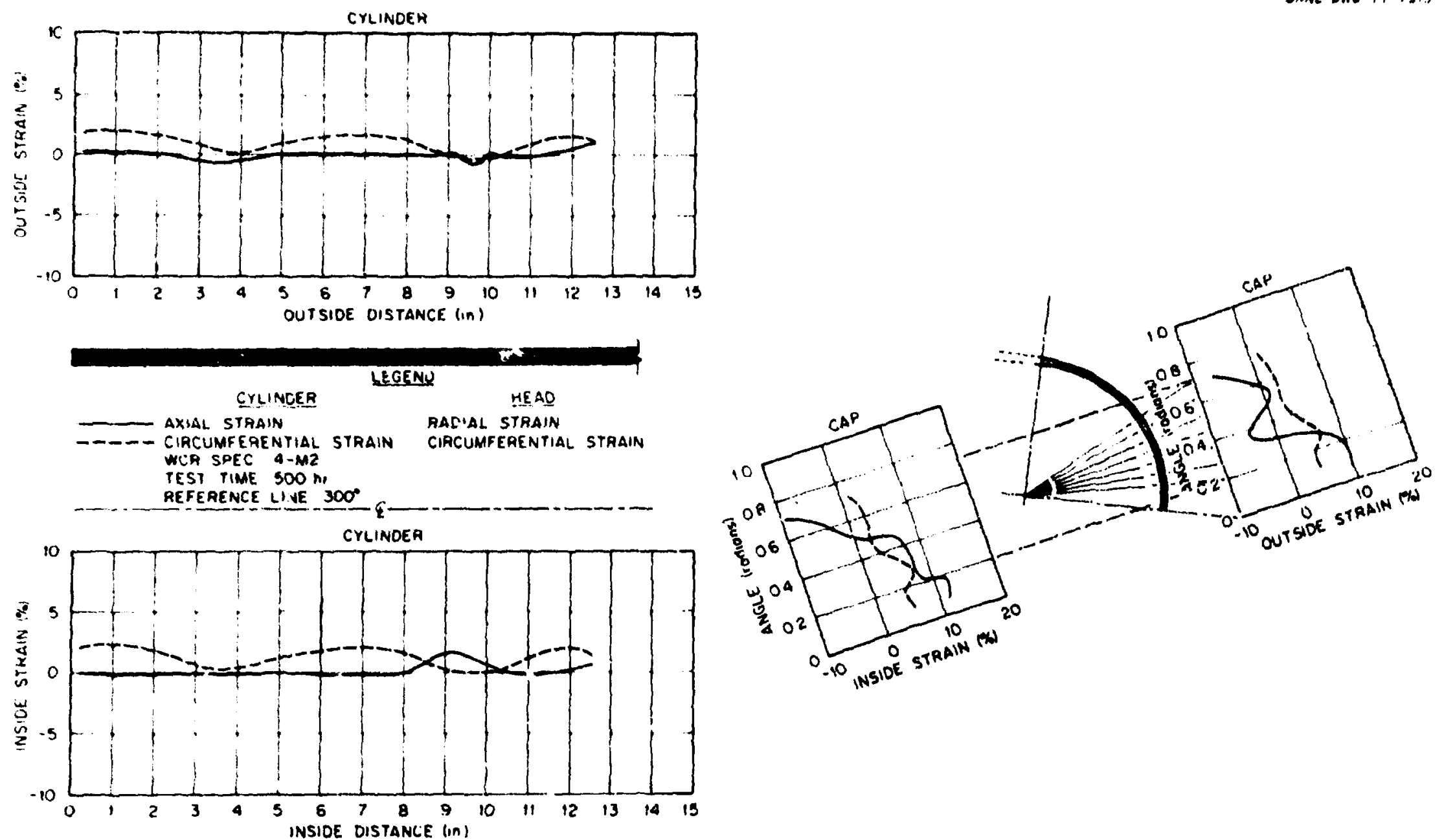

Fig. Al5-f. Surface strain distribution for specimen 4-Me along the axial reference plane, $\theta=300^{\circ}$, at $500 \mathrm{hr}$ (1 in. $=2.54 \mathrm{~cm}$ ). 

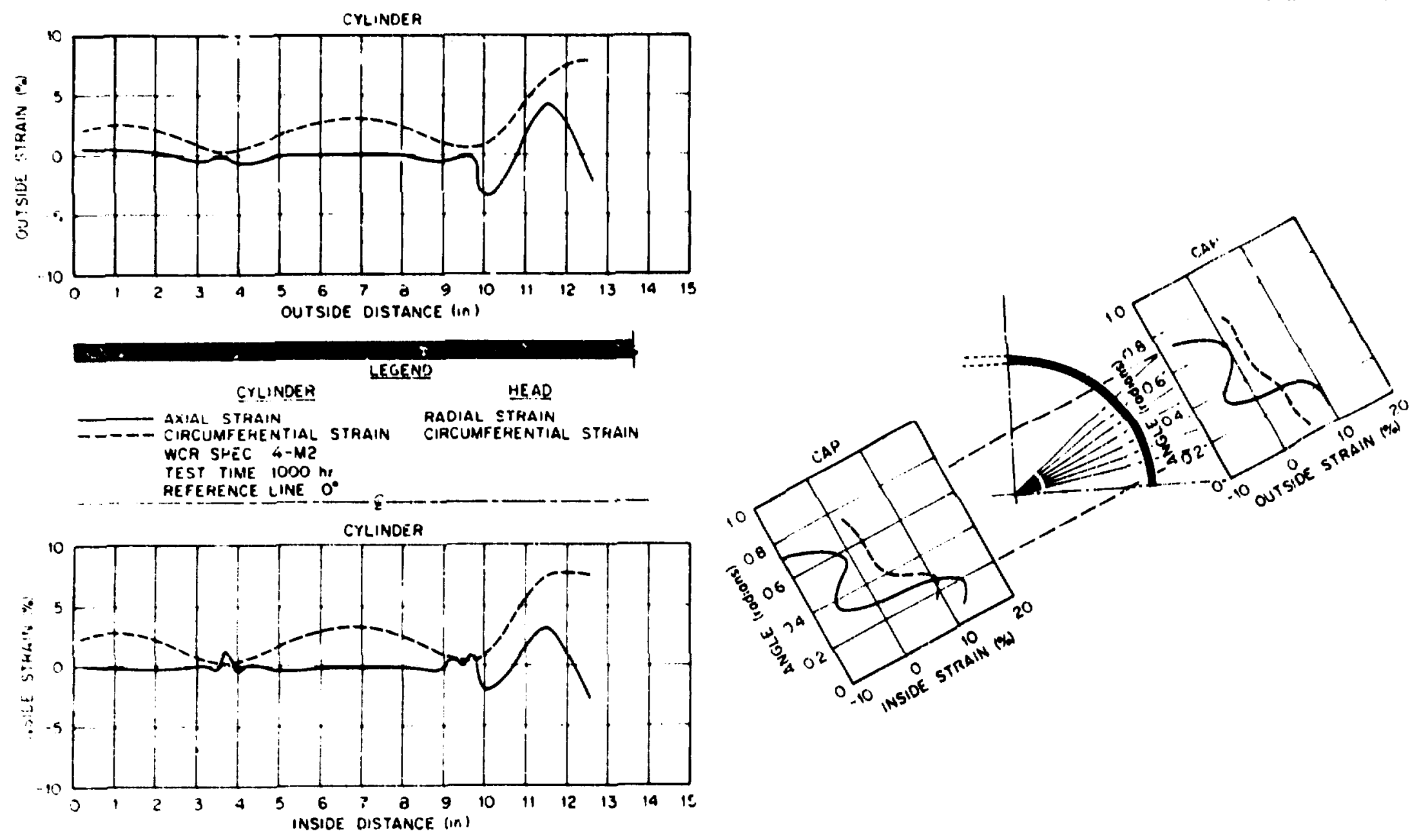

Fig. A16-a. Surface strain distributiun for specimen 4-M2 allong the axtal reference plane, $\theta=0^{\circ}$, at $1000 \mathrm{hr}(1 \mathrm{in},=2.54 \mathrm{~cm})$. 

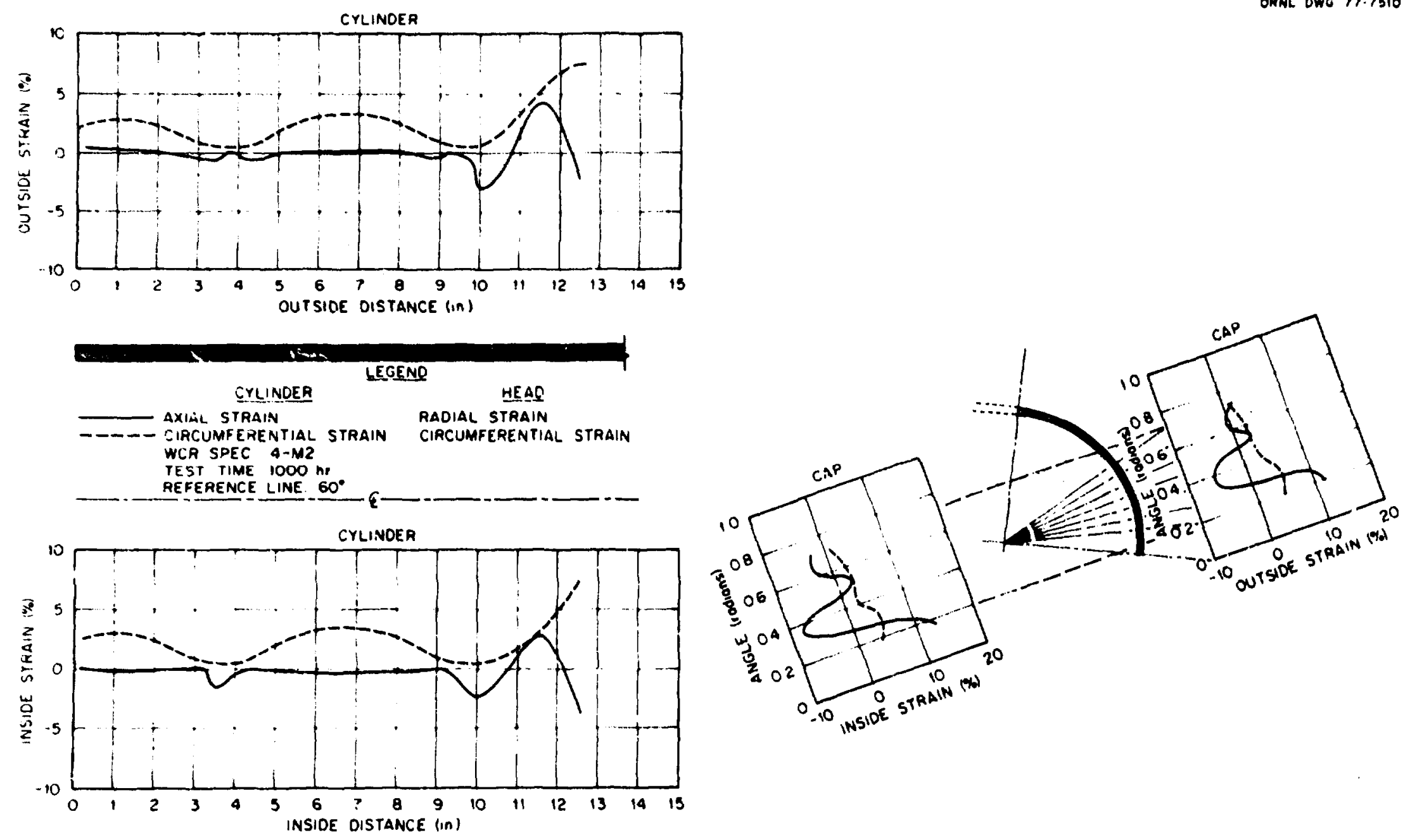

Fib. Al6-b. Surface strain distribution for specimen 4-112 along the axial reference plane, $\theta=60^{\circ}$, at $1000 \mathrm{hr}$ (l in. $=2.54 \mathrm{~cm}$ ). 

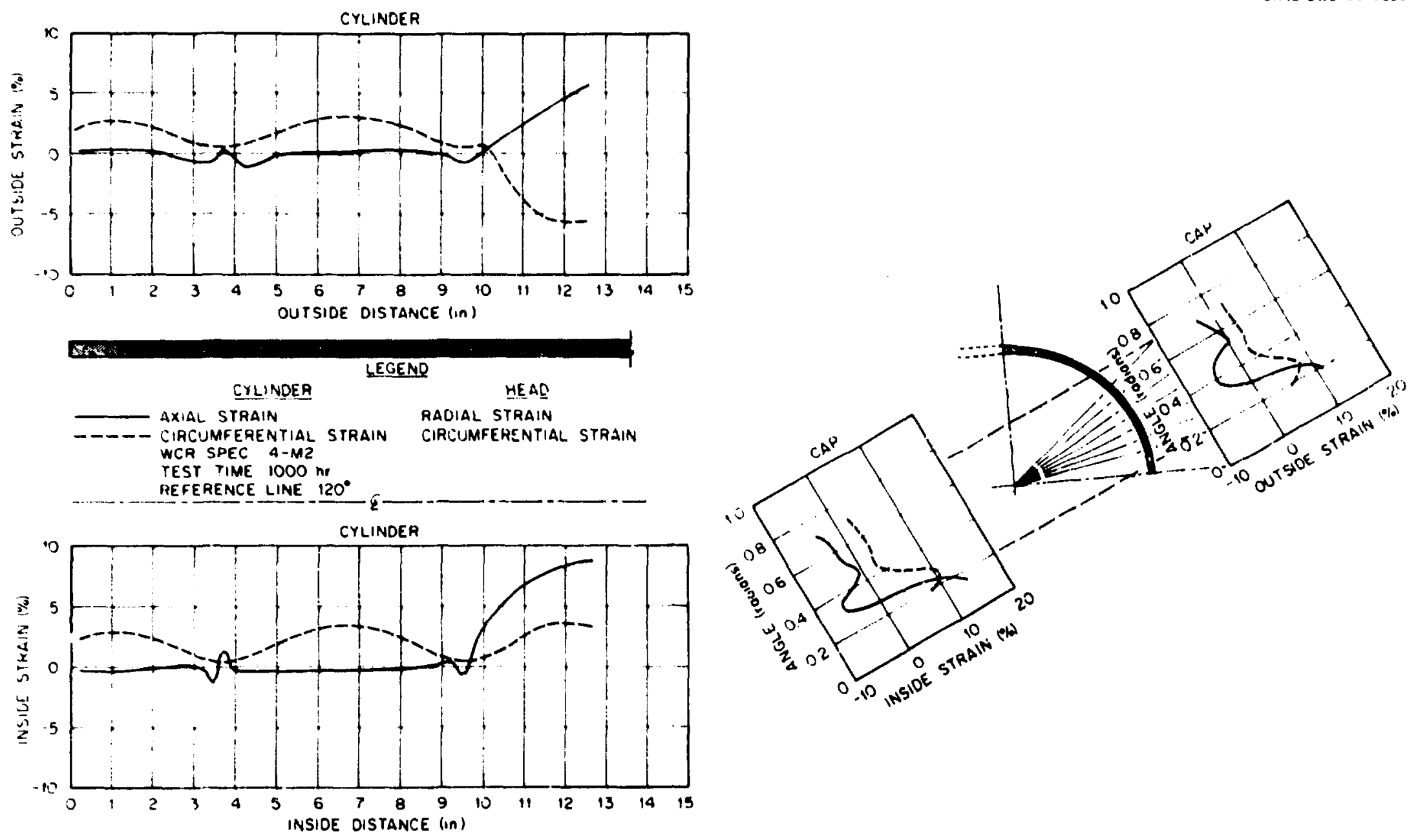

Fig. Al6-c. Surface strain distribution for specimen 4-M2 along the axial reference plane, $\theta=120^{\circ}$, at $1000 \mathrm{hr}(1 \mathrm{ln} .=2.54 \mathrm{~cm})$. 

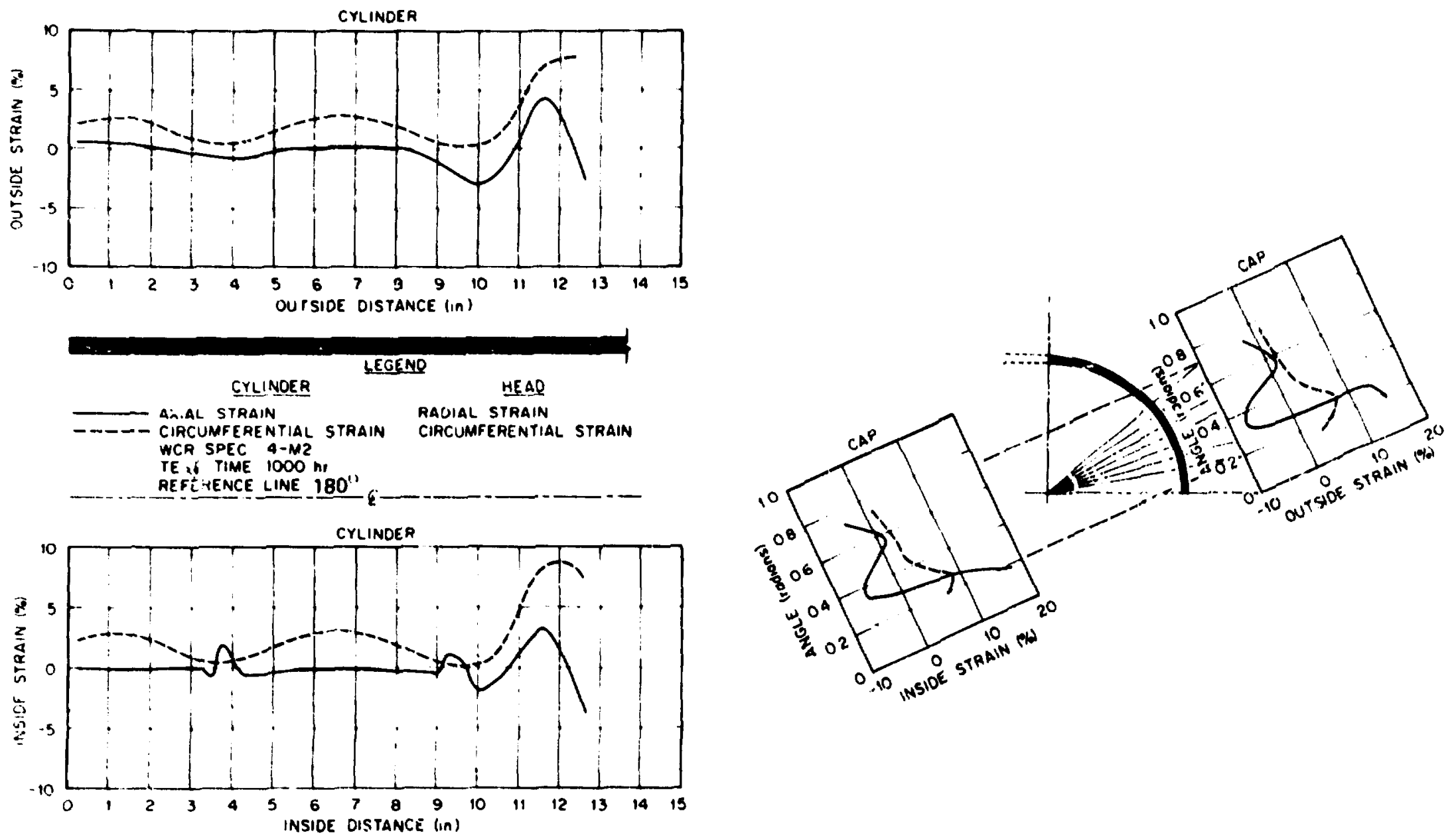

Fig. Al6-d. Surface strain distriuution for specimen 4-M2 along the axial reference plane, $\theta=180^{\circ}$, at $1000 \mathrm{hr}(1 \mathrm{in} .=2.54 \mathrm{~cm})$. 

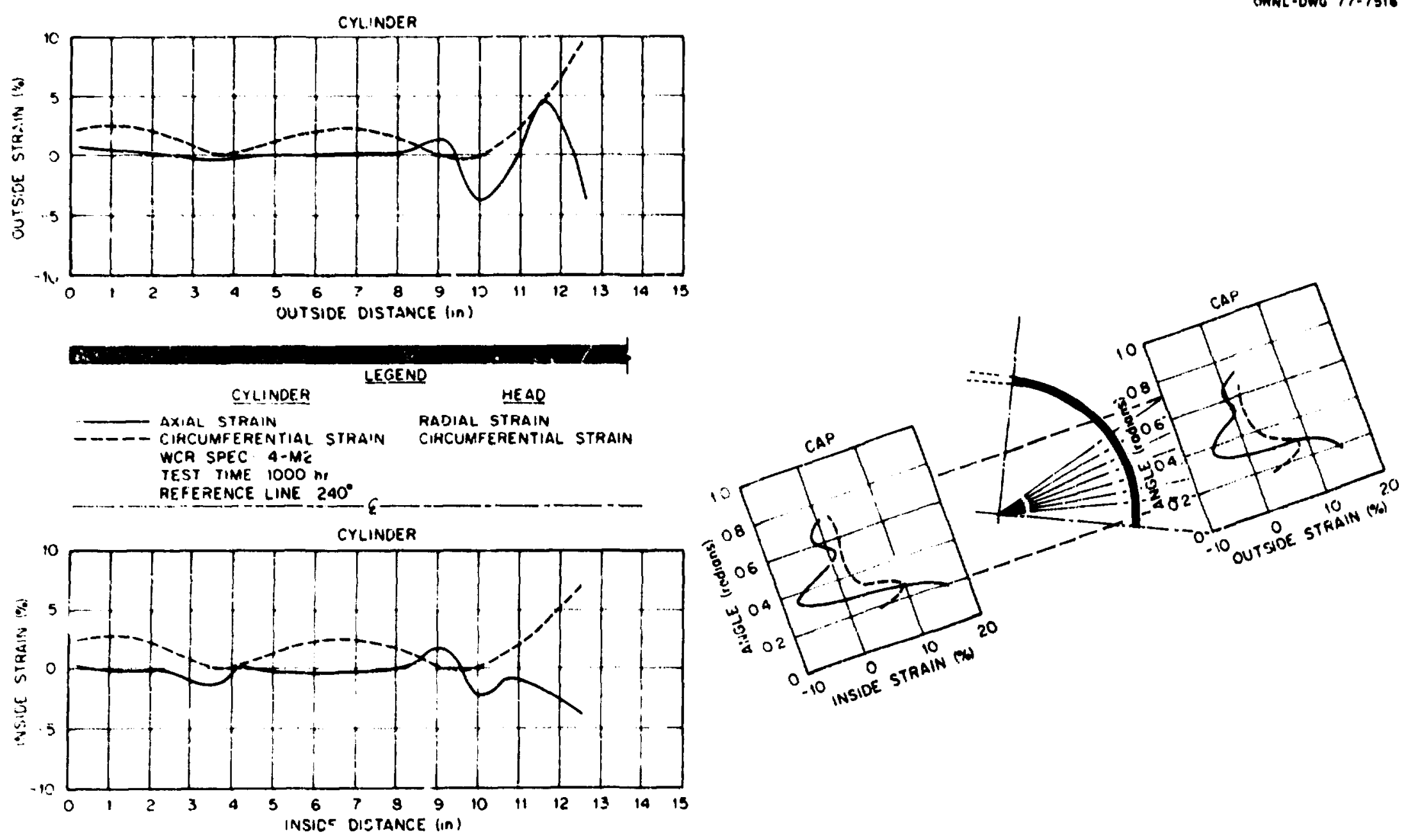

Fig. Al6-e. Surface strain distribution for specimen 4-M2 along the axial reference plane, $\theta=240^{\circ}$, at $1000 \mathrm{hr}(1 \mathrm{ln} .=2.54 \mathrm{~cm})$. 

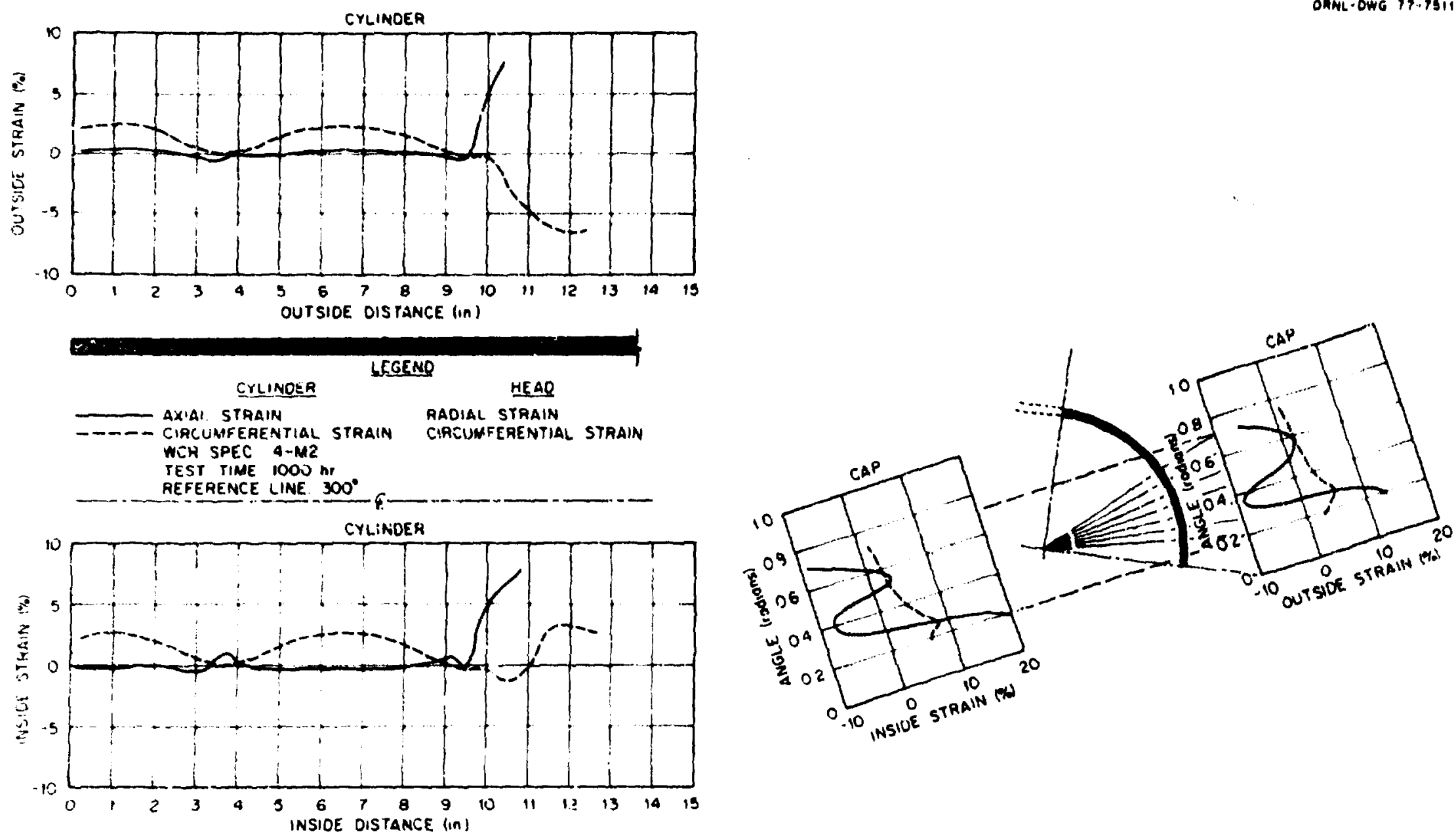

Fig. Al6-f. Surface strain distribution for specimen 4-M2 along the axial reference plane, $\theta=300^{\circ}$, at $1000 \mathrm{hr}$ ( $1 \mathrm{in} .=2.54 \mathrm{~cm}$ ). 